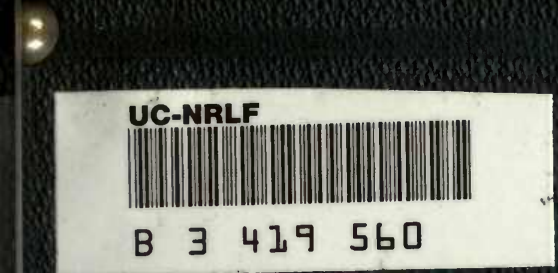

B 3419560 


\section{WOODEN CROSS-SECTION CARDS.}

\section{FOR FANCY AND BUSINESS PURPOSES.}

(Fatented Feb. $9, \mathbf{8 8 6 . )}$

The novelty and attractiveness of these Wooden cards cut across the grain will at once recommend them to every admirer of woods.

They are manufactured from timbers of close grain and their toughness, ivory like smoothness and beauty are a surprise

Their Printing Quali are of greatest value as

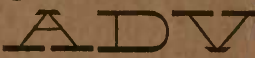

This is owing to the fact cipients of such cards are friends as something curi advertisement.

They are also approp CALLING CAI

\section{RECEPTION}

Being perfectly adapte or plain as gift cards of al pretty use.

N. B. In using water co the admixture of a little turpet punch; and when using with \& the surface the card is to be $\mathrm{gli}$

For scale of sizes see oppos
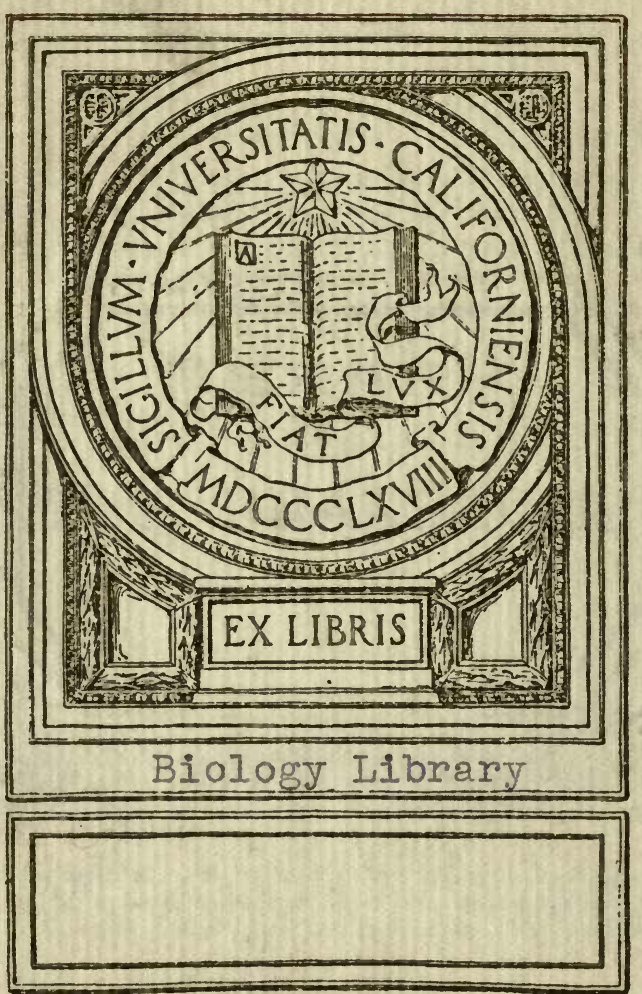

by any Paper, and they

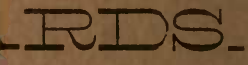

lon at once, and the reshowing them to their displaying the imprinted

VG AND

\section{;, ETC., ETC.}

e used thus embellished try these cards for this with Colors "cut" the oil by , use a solid or "conductor's' not upon the card but, upon

\section{STER}

These are perfect for displaying before an audience by means of a magic-lantern, the structure of our various timbers. All the principal species are designed to be represented and each one is identified beyond question of doubt. No one who has an instrument should be without these interesting and instructive preparations.

\section{MICROSCOPIC PREPARATIONS OF WOODS.}

These, like the stereopticon mounts, are authentic and elegantly prepared. Each slide contains three sections-transverse, radial, and tangential - which give a most perfect opportunity for studying the minute structure.

\section{PREPARATIONS OF WOODS SHOWING PRISMATIC COLORS.}

Although wood is so common a substance, very few people have ever known of these interesting and beautiful phenomena. For mention of one form of the display of colors, such as seen in the $\mathrm{Cu}$ cumber Wood, see accompanying text p. 40, Note.

Prices furnished upon application. 
SD 536

455

$V_{1}$

Lockea

case

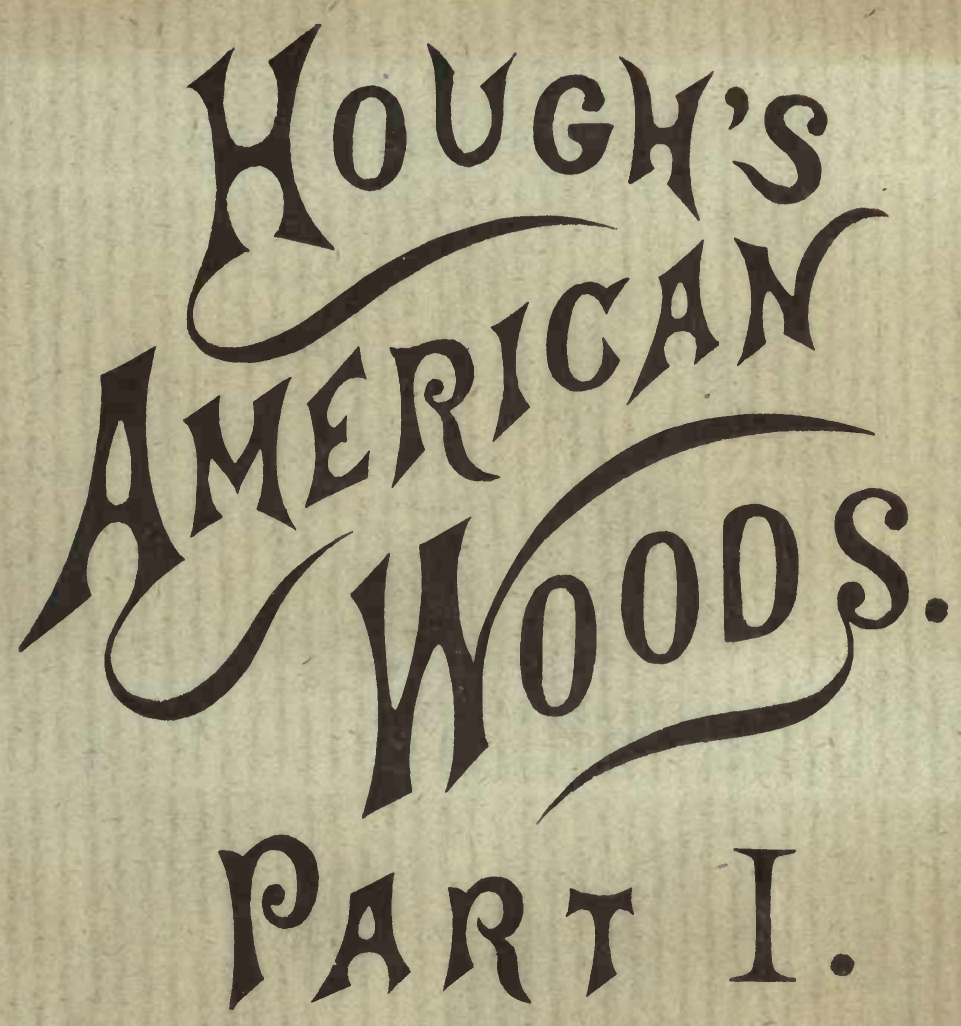




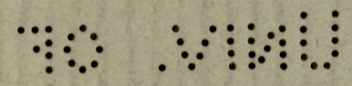
¿ 


\section{AMERICAN WOODS,}

EXHIBITED BY ACTUAL SPECIMENS

AND WITH COPIOUS EXPLANATORY TEXT,

BY

ROMEYN B. HOUGH, B. A.

PART I.

REPRESENTING TWENTY-FIVE SPECIES

BY

TWENTY-SEVEN SETS OF SECTIONS.

LOWVILLE, N. Y., U. S. A.:

PUBLISHED AND SECTIONS PREPARED BY THE AUTHOR.

I 888 . 
TO

\section{T王F MFMORY OF}

MY FATHER,

\section{FRANKLIN B. HOUGH,}

AS AN EXPRESSION UF GRATITUDE FUR THE CARE TAKEN TD INCLINE MY FIRST THQUGHTS TQ A CONTEMPLATION QF THE WTRRKS QF NATURE, FUR GUIDANCE AND CONSTANT INSPIRATION

IN AFTER YEARS, AND BUT FUR WHASE SUGGES-

TION THIS WORK WUULD NEYER HAYE AP-

PEARED, IT IS MUST AFFECTION-

HTELY DEDICATED. 



\section{PREFACE.}

The necessity of more generally diffused information concerning the variety and importance of our forest trees is justification enough for the appearance of this work, especially at this day, when the demands of Forestry in this country are constantly more and more keenly felt. The work was undertaken at the suggestion of my father, whose intense interest in Forestry, and a kindred taste, at once gave me inspiration to the work. It was entered upon with the expectation of his valuable companionship and counsel during its progress, but, alas! that I was destined to have only at the outset, and, while I was then left ever to mourn the loss of a kind father, companion and teacher, the reader must fail to find in these pages that value and finish which his mind would have given them.

Among the happiest pictures of my memory are those in which I see my father's delight, as I would show to him, from time to time, my successful progress in devising a way of making the sections for this work, and if only for the happiness which its appearance would have caused him, could he have lived until this day, I have felt duty-bound to go on with it, even though left to do it alone.

The work is the outgrowth of one, of somewhat similar plan, proposed by my father some years since, but which he did not carry into effect. Its design is primarily and principally to show, in as compact and perfect a manner as possible, authentic specimens of our American woods, both native and introduced. For that end three sections, respectively transverse, radial and tangential to the grain (see Glossary), are made of each timber, sufficiently thin to allow in a measure the transmission of light, and securely mounted in well made frames.

The three planes above mentioned show the grain from all sides, so to speak, no plane being possible but that would be either one of them or a combination of them. The difficulty, however, of cutting a great number of sections exactly on those planes is obvious, so let it be understood that the terms, "transverse," "radial" and "tangential," are, in many cases, only approximately exact in their application. 
My endeavor is to show, either in a part or all of the sections standing to represent a species, both the heart and sap-wood, but with some woods as the Sumach, for instance, where usually only the outermost ring, or a part of it, could be said to represent the sap-wood, the display of that is quite impossible. In certain other woods, as the Spruce, etc., the transition from sap to heart-wood is almost indistinguishable by any difference in color, and, although both may be shown in the sections, one can scarcely distinguish between them.

The text of this work has been added rather as a secondary matter, to supply to those not having it in other form, such information as is of importance, in connection with the wood specimens, to give a fairly good acquaintance with the trees represented. It contains little, if any thing, new to the botanist, but to others it is hoped it may be of some value.

In its preparation some use has been made of my father's Elements of Forestry, and thanks are due the publishers of that work-Messrs. Robert Clarke \& Co. of Cincinnati, Ohio - for the use of euts in reproducing a number of its illustrations. Other valuable books of reference have been the works of Drs. Gray, Wood and Bessey, LeMaout and Decaisne's Descriptive and Analytical Botany, Prof. C. S. Sargent's Report on the Forest Trees of North America, (constituting Vol. IX, Ninth Census of the United States, 1880), Micheaux and Nuttall's North American Sylva, George B. Emerson's Trees and Shrubs of Massachusetts, D. J. Browne's Trees of America, etc.

I gratefully acknowledge the courtesies extended by Professors W. R. Dudley, Charles E. Bessey, and to my classmate and companion on many a "botanical tramp," Prof. William Trelease, as well as others whose names I have not space to mention, but towards whom the same gratitude is felt. To Rev. J. Hermann Wibbe, Prof. Leo Lesquereux and Mrs. Elizabeth G. Britton, for aid in determining respectively the German, French and Spanish synonyms, I am heartily grateful. Last, but by no means least, I have to acknowledge the very material aid received first from my father's counsel in planning the work, and then from other's as near and dear, in its prosecution, proof-reading, etc.

To those not familiar with the scientific classification of natural objects, a few words must be said regarding that and the application of descriptions. A number of species, having certain characters in common, are gathered together into a group, called a genus (pl.genera), and a number of these in turn, upon the strength of common characters, into a higher group called an order, and still higher are various other groupings, ranked by authors under various names. The order, then, is made up of genera and the genus of species, and since it is customary in technical descriptions to define these groups, so I have done 
with those species, we have to consider. In studying the descriptions one must commence with the order or highest group, and work down to the species, in order to learn all the characters of that species.

It will be noticed that each species is labeled with technical, English, German, French and Spanish names. The technical or scientific name is derived usually from the Greek and Latin, and is of inestimable value to the scientific world because of its exactness, and of its being understood in all nations. Following the technical name are the English synonyms in most common use, and then the German, French and Spanish names. But naturally in a country like this, where the English language almost universally prevails, our native trees have no colloquial names in other languages. In such cases we have simply translated either the technical or English name. Their value, therefore, as synonyms strictly speaking, must be taken with some latitude. With a few species colloquial names in foreign languages have been found, and in such cases preference has been given them.

The authenticity of the timbers represented in this work has been a subject of personal attention and special care on the part of the author. The trees selected for specimens have been identified in the field, before felling, while the leaves, flowers or fruit (one or all) have been obtainable, and he ean, hence, vouch for the authenticity of every specimen represented.

Succeeding parts, uniform in style with Part I., and representing in each case twenty-five additional species, are planned to appear later, with the ultimate end in view, of representing, as nearly as possible, all of the American woods, or at least the most important, in such a series of volumes as this one.

Upon the reception which this meets in public favor, and upon the co-operation of those interested in the cause, must naturally depend the carrying out of that plan. It is hoped that greater experience and skill will enable us to obviate in future parts the faults which occur, from lack of those qualities, in this.

Notice of errors in this work will be thankfully received in hopes of profiting therefrom in the future.

Lowville, N. Y., March 30, 1888. 



\section{INTRODUCTION.}

1. It has been deemed imperative by way of introduction to the study of the trees included in this series, to give something of an account of the technical terms used in descriptive botany. They are words of peculiar and very exact signification, and in this, as in other branches of science, their use is of necessity, if we would describe an object, as a plant for instance, with such accuracy as to enable one to recognize it from our description.

2. A clear understanding, therefore, of the technical terms so far as used in this work must be had at the outset. But great technicality we have endeavored to avoid, from the fact that those already familiar with the species represented will not need the descriptions, and for those who are not, and for whom they are introduced, they must be made as simple as possible.

3. While this preparatory part then is necessary, we shall endearor to keep it within as strict limits as the object in hand will permit. Much that should be included, were we to study all plants, herbaceous as well as woody, will not here be needed and consequently will not be tonched upon.

4. A plant - of which of course a tree is only a large example - consists primarily of three organs, the root, the stem and the leaf. These are all that are necessary, so far as the plant itself is concerned, for the performance of the one great purpose of the vegetable kingdom - the conversion of inorganic into organic matter.

5. When special functions are to be performed, such as the reproduction of the species, protection to the plant or storage of food for its future use, etc., no new organs are created. Those already existing are simply altered in their functions and so specialized as to meet the desired end.

6. The Root we will not stop to consider, as it is unimportant to our present purpose. The stem will need but little space. The leaf and its morphology, to a certain extent, will require considerable.

\section{The Stem.}

7. This in trees is spoken of as the trunk, and it needs our consideration here only so much as to look a little into its structure and determine its method of growth, for by this we may know in which of the two great classes of Flowering Plants it belongs. But before defining these classes we will have to understand something of the

8. Structure of Wood. The elements which make up the substance of wood, or the parts of which it is ultimately composed, are cells,minutc closed cavities, - elongated in the direction of the grain, with 
"xtremities tapering is a point and more or less thickened walls. Their tapering ends overlap each other, and in this way give greater strength and tomerhess to the tiscrue.

9. The Walls of contiguons cells are fomel ho have pits or thin spots

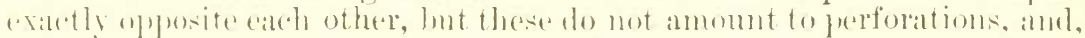

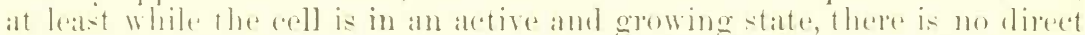
combertion of passageway between the interior of one and that of amother. 'T'he pits are usially phanly discernible moler a mieroseope of high power. Fig. 1 represents a few wood-ecels from line timber and the (amplatratively barge pits there shown,- abllad hordered

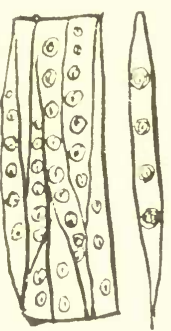

FIri. 1. jits- are chat ructeristic of all the representations of the l'ine famils.

10. By a poreess known as osmosis the salp passes from

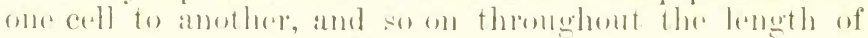
the trin.

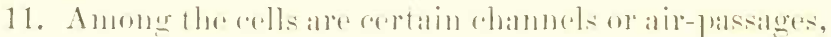
which ane often in large as to be plainly visible to the

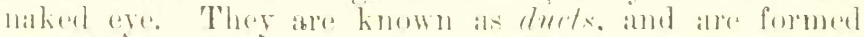

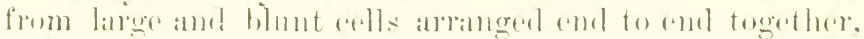
and in time their end partitions beeome more of less obliterated. There walls are variously matred with promi-

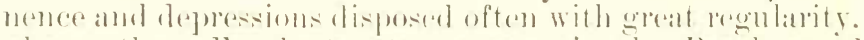

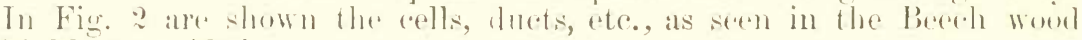
highty mannified.

12. It would be interesting to dwell longere on the mireroseopice strosetme of woorl, ams stmly its womlerfol forms amd arrangement: hut we will have to leave that to the rearler, whor with his magnitier ain see for himself comsiderable, eren in the aceompanying sections, althomeh thimmer sections are mandrel for high magnifirations.

13. Such in hrief is the strueture of what is known as the "fibro-vasenlate" system, which malkes up the substance of woorl. Its arrangement in the stem may he in either one of two wats. and 11 mont this is bated the first division in the ratsifuation of lilowering Plit1t:-

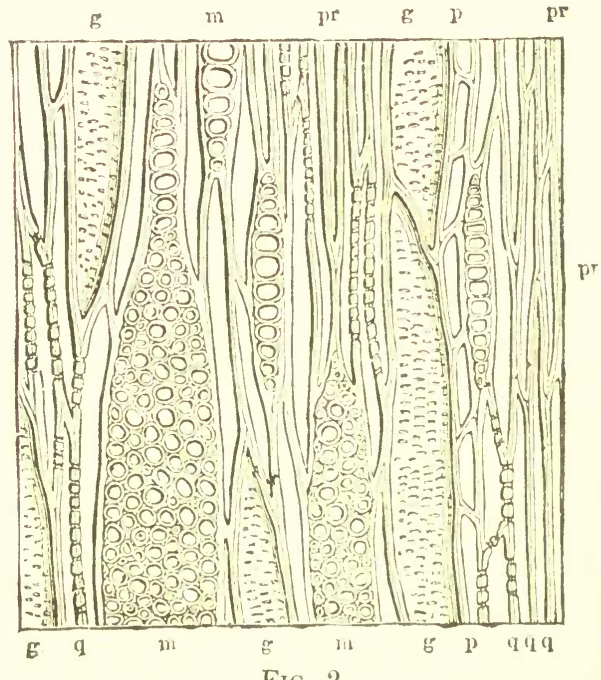

Fin. 2.

11. The Exogenous Stem. (I. or from or omtsillo of and gemus

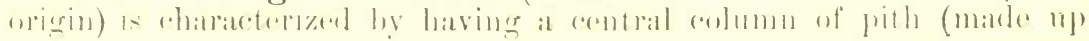

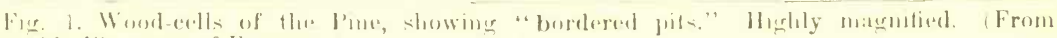
I! melis: Element - of Formetry.)

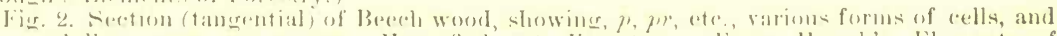
$m$, medullary rays cut across. Magmeded 20 diameters. from llough's Elements of Forestry.) 
of subspherical cells) and this surrounded by wood-a layer of fibrovascular tissue - which in turn is surrounded by bark. Such a stem increases in thickness by the growth of new tissue between the wood and bark, adding each year a new sheath - ring as seen in cross-section - to the outside of the wood (whence the name) and a new lining to the bark. All the trees of the colder climates belong to this class.

15. There exists in the wood of exogenous stems, besides the fiber described above (8-11), medullary rays, which make the silver-grain in the language of wood workers. They are narrow plates radiating from pith to bark, and are composed of short flattened cells. They are shown in Fig. 2, $m$, as cut across and highly magnified, and in Fig. 3 as seen from all sides. The transverse section, $Q$ (Fig. 3) shows them as seen from above, resembling lines radiating out from the center. 'The radial section, $S p$, shows their width, the transverse, $Q$, their thickness and length, and the tangential, Sc, as cut across. Their great range of variation in size and appearance in different timbers can be beautifully studied in the wood sections, which are designed to be cut on those planes.

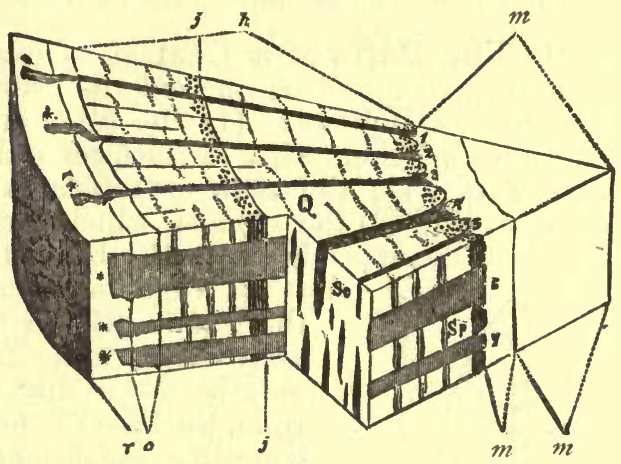

Fra. 3.

16. The Endogenous Stem. (L. endo, within, and genus, origin) is characterized by having the wood disposed in threads or bundles (called fibro-vascular bundles) throughont the pithlike substance of the interior. It increases in thickness by the growth of new bundles within the stem (whence its name), and it has no real bark. The class is represented by the Palms and similar trees of tropical countries, and in colder climates by many herbaceous plants. The Indian Corn is a familiar example in the North and the Palmetto in the South.

\section{The Leaf.}

17. This is a thin, expanded organ for presenting a large amount of surface to the action of sun-light and air, and this for the performance of one of the most important workings of Nature. The function referred to is known as assimulation, or the conversion of mineral or inorganic matter into living or organic matter, and upon it directly or indirectly depend all forms of life. Nowhere else in the whole realm of Nature is this work performed than in plants, and there by the agency of its leaves, to which the rest of the plant each part in its way is accessory.

18. How the sap is brought up through the substance of the stem to

Fig. 3. Structure of the Oak at two years of age, showing, $m$ (upper side), pith consisting $n f, m^{\prime}$, spong portion and, $m$ (under side), medullary sheath; $h$, wood of two years growth, $j j$ being the dividing line; $c$, cambium layer; $r$, bark and, $1-7$, medullary rays, $Q$ represents the transverse section, $S p$ the radial and $S c$ the tangential sections. (From Hough's Elements of Forestry.) 
the leaf, and there comes in contact with the air which enters through the myriads of stomata - little months or breathing pores - which cover its surface, and how, so far as we can see, the function is there performed, are studies full of greatest interest. But it would be foreign to the object of this text to further follow them now, however enticing.

19. Nor can we in this place touch upon the interesting subject of the differentiation of leaves for special purposes, such as for pitchers, flytraps, a means of support or defense, depositories for food, etc. All such are found, and one can scarcely walk far in the fields in summer without finding examples.

20. We must here turn our attention to the forms of leaves and such of their points as are important in the identification of trees.

21. The Parts of a Leaf, if we examine one such as we would call typical, perfect and serving only its primary purpose - that of foliage are three, as follows:-(1) the blade or lamina, which is the flat and expanded portion, with its surfaces ordinarily presented upwards and downwards; (2) the stalk or petiole, which supports the blade on its summit, and (3) the stipules, which are two usually small and more or less leaf-like appendages at the base of the petiole, one on each side.

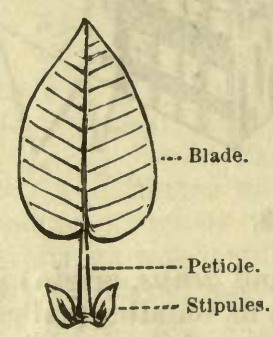

Fra. 4. 22. Very commonly the stipules are absent when the leaf is said to be exstipulate. They often fall away early, while the leaf is expanding, or they may persist as little blades at, but quite distinct from, the base of the petiole, or adnate to it making wing-like expansions. Occasionally their margins are united so as to form a sheath surrounding the base of the petiole as seen in the Sycamore. In color and substance they may be like the leaf, but are often of different color, or colorless, and thin and membraneous.

23. Sometimes the petiole is absent, the blade springing immediately from the stem of the plant. Such leaves are called sessile, i. e., seated (from L. sedeo to sit.)

24. 'The term "leaf," as ordinarily used, is applied to the blade, which is its most conspicuous and important part.

25. On further examination of our leaf we will see that it is made up of a framework, consisting of a fibrous or woody material, and a softer part, a green pulp, filling in the interstices. The framework is plainly arranged, so as to give the leaf stiffness and support, and we speak of it as consisting of ribs and veins.

26. When there is a central main branch, it is known as the midrib, and the branches leading off from this on each side are spoken of as the veins, and their branches as veinlets. This leads us to the study of

$2 \%$. Venation, - the arrangement of the ribs and veins of a leaf. This is a subject of great importance, and, with other features which are quite constantly associated, it enters as an important matter in the classification of plants. We shall see that there are primarily two grand systems of venation. The leaves representing one system are spoken of as

28. Netted-veined or Reticulated - when there are one or several main

Fig. 4. A Simple, Pinnately-veined Leaf, showing parts. 
ribs, from along which branches lead off dividing and subdividing several times, and then finally anastomosing so as to form literally a net-work of veins; whence the name of this kind of venation. (Figs. 19 and 41.)

29. When there is a single main rib running through the center of the leaf from base to apex, and sending off branches from each side like the vanes of a feather, it is said to be feather-veined or pinnately veined (from L. pinna, a feather.) These leaves are usually longer than broad. (Figs. 4 and 19.)

30 . When there are several main ribs radiating from the summit of the petiole through the substance of the leaf, and these in turn sending out their branches, the leaf is said to be from that fact radiate-veined or palmately (from L. palma, the hand) or digitately (from L. digitus, the finger) veined, from resemblance to the hand, with fingers spread apart. (Fig. 5.) Leaves of this type are broader in proportion to length than the pinnately veined. Contrasted with the nettedveined leaves are the

31. Parallel-veined, where the veins commence at the base of the leaf, and run approximately parallel to the summit, where they again unite, and only minute simple cross-veinlets, if any, are given off. Leaves of this sort are seen in Grasses, Wheat, Indian Corn, Solomon's Seal, etc. A modification of this kind of venation is seen in the Calla, Banana, ete., where the veins run out transversely to the margins.

32. The plants having parallel veined leaves comprise a large and important.class, but in temperate climates they are nearly all herbaceous and not for

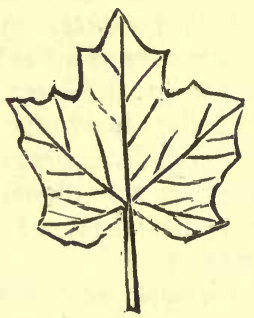

Fig. 5. our consideration here.

33. The Forms of Leaves are intimately connected with the venation. They are very various, but as a rule quite constant within the same species, and consequently form an important item in the classification of plants.

34. We need to consider especially the elongated types as most commonly seen associated with the pinnate venation. 'To get the best idea of the furms of these leaves, we might group them as follows:-(1) those of about uniform width; ( 2 ) those broadest near the base; (3) at about the center, and (4) near the apex. Taking them in this order a leaf is said to be

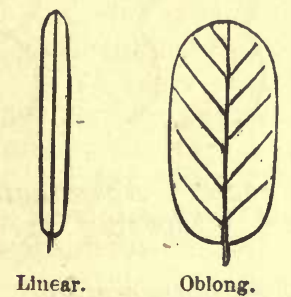

Fig. 6. Fig. 7.

Linear, when the sides are parallel,

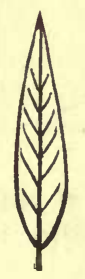
i. e., when it is of uniform width, and is several or many times longer than broad. (Fig. 6.)

Oblong, when of uniform width, but only two or three times as long as broad. (Fig. \%.)

Lanceolate, when broadest at the base, and tapering to the apex or both Lanceolate. ways, and is four or five times or more Fig. 8. longer than broad. (Fig. 8.) 
Ovate, similar to lanceolate, but with length not more than two or three times the width. (Fig. 9.)

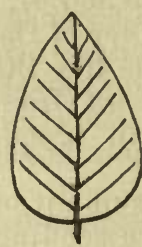

Ovate.

FIG. 9.

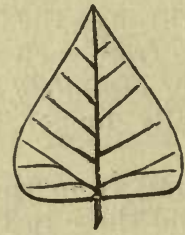

Deltold.

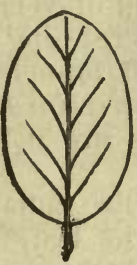

Elliptical.

Deltoid, triangular in shape like the Greek letter, Delta, from which it takes its name. (Fig. 10.)

Elliptical, when broadest in the center, two or three times as long as broad, and the ends of about the same width. (Fig. 11.)

Oval or broadly Elliptical, same but proportionally broader, the

Fra. 10.

FIG. 11. length being considerably less than twice the width. It is between elliptical and orbicular or rotund, where length and breadth are abont equal. (Fig. 12.)

Oblanceolate, same as lanceolate, but reversed so as to be broadest near the apex, the long taper to the petiole and the short one to the apex.

Spatulate, shaped like a spatula similar to oblanceolate, but with rounded instead of pointed apex. (Fig. 13.)

Cuneate or cuneiform, when shaped like a wedge, broadest at the trun-

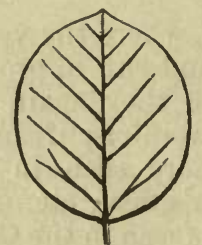

Orbicular. FIG. 12.

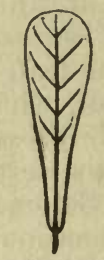

Spatulate.

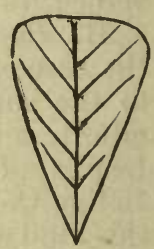

Cuneate.

FIG. 14. cate apex and tapering uniformly to the base. (Fig. 14.) Obovate, similar to ovate but reversed - the broadest part near the apex, and base narrow.

35. The Base and the Apex of the Leaf are also important points to observe, and the principal forms for our present consideration may be seen, with the names applied to them, in the accompanying diagrams. (Fig. 15.)
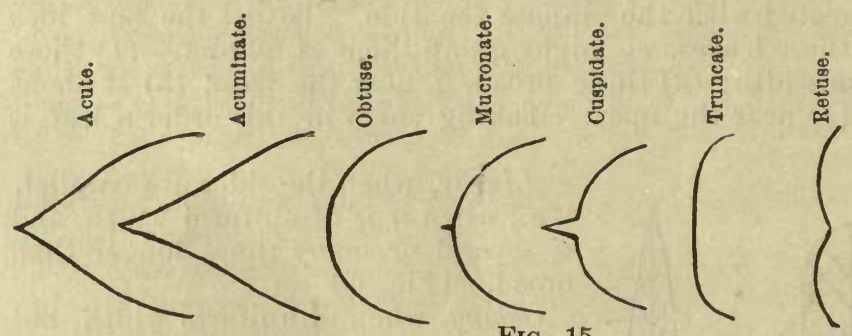

FIA. 15.

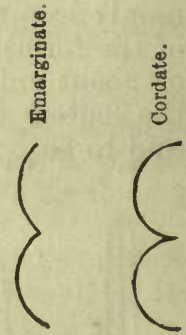

Acule, when the sides come together at an acute angle. Acuminate or taper-pointed, when the taper is more prolonged - tapering to a sharper point.

Obtuse when blunt or rounded, the sides meeting at an obtuse angle.

Mucronate, when an obtuse apex is tipped with a small abrupt point.

Fig. 15. Forms of Base and Apex of Leaves. 
Aristate or awn-pointed, like mucronate but with a longer and more or less bristle-shape point.

Cuspidate, when the point is sharp and rigid.

Truncate, when an extremity is so blunt as to seem cut squarely off. Retuse, when slightly notehed. Emarginate, when more decidedly notehed. Cordate or heart-shaped, when deeply emarginate at the base. Obcordate, when deeply emarginate at the apex.

36 . While the bases of opposite sides of a leaf usually develop about uniformly it is not always the case, and such leaves are spoken of as oblique or inequilateral at base. They are quite characteristic of the Elms, and Fig. 15 shows some of these leaves, but there the obliquity is not so marked as is often the case.

37. The Margin of the Leaf, as shown in Fig. 16 is

Entire, when of even continuous outline - without projections or indentations.

Serrate, when furnished with small and sharp teeth, pointing towards the apex, like the teeth of a saw.

Dentate, when the teeth are small and point outward from the center of the leaf instead of forward.

Incised or jagged, when the teeth are long, sharp and irregular.

Crenate, similar to dentate, but with broad and rounded teeth.

Undulate, wavy or repand, when slightly scalloped with wavy outline.

Sinnate, same as undulate, but with deeper indentations, which here and in the following classes are called sinuses.

Lobed, when the sinuses are more or less rounded and deeper, but entering not more than half way to the midrib or base of the leaf. "The term "lobed" is often applied in a general way, regardless of the depth or form of the sinuses, when the leaf is cut into a definite number of lobes, and it is said to be two-lobed, fivelobed, many-lobed, etc., as the case may be.

Cleft, same as lobed, but with usually narrow and pointed sinuses entering half way to the midrib or base.

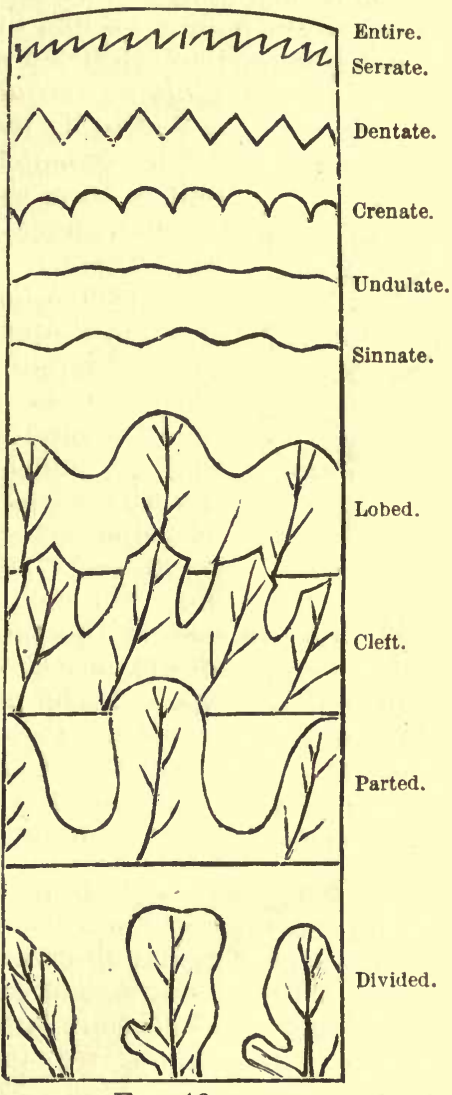

FIG. 16.

Parted, when the incisions enter nearly to the midrib or base.

Divided, when they reach the midrib or base; and this leads us to the consideration of

38. The Compound Leaf - a leaf consisting of several blades, with a common petiole or main leaf-stalk (Figs. 17 and 18), and in this differ- 
ing from the simple leaf, as already described (Fig. 4), which has but a single blade. 'The separate blades of a compound leaf are called leaflets and the foregoing terms, used of the form, margin, ete., of the simple leaf, are equally applicable to the leaflet. 'They may be sessile on the main leaf-stalk, or they may be supported on stalklets of their owncalled petiolules - and these may or may not be jointed or articulated to the main stalk, just as that is to the branch. There are two classes of compound leaves, corresponding to each other as do the pinnately and palmately-veined simple leaves. They are as follows:

39. Pinnately compound, when the leaflets are arranged along the common leaf-stalk - here called the rachis - like the vanes of a feather (whence the name), or like the veins of a pinnately-veined simple leaf. When the rachis terminates with a single leaflet the leaf is said to be

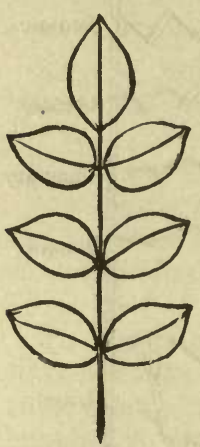

Fic. 17. oddly or unequally pinnate; when with a pair of leaflets it is said to be evenly, equally or abruptly pimnate.

40. Palmately or digitately compound, when the leaflets radiate frum the summit of the leaf-stalk as do the veins of the palmately-veined simple leaf. (Fig. 18. Compare with Fig. 5.)

41. Sometimes the divisions of a compound leaf instead of being simple leaflets are themselves compounded, when the leaf is said to be twice compound, in which case one of the main divisions is called a pinna (pl. pinnae) and its subdivisions are called leaflets; when these are compounded they are called pinnules and their subdivision leaflets, and the whole leaf is said to be thrice compound-pinnately or palmately as the case may be. The subdividing may go on still further, and on the same plant it may be variable. For such leaves the term decompound is used.

42. By the use of the prefixes bi, tri, etc. (from L. bis, twice, ter, thrice, etc.), and the adjective foliate (I. folium, leaf), the number of leaflets of a compound leaf may be designated, and the leaf is sild to be pinnately or palmately bifoliate, trifoliate (or ternate), etc., as there are two, three, etc., leaflets. Using the same prefix to designate the number of times compounded a leaf is said to be bipinnate or tripinnate when twice or thrice pinnately compound, etc.

\section{The Arrangement of Leaves on the} Stem (technically known as phyllotaxy) is not by chance, as the casual observer might suppose. The place for the appearance of each leaf is determined beforehand, and by certain laws very exact and beautiful in their workings. We cannot, however, consider them to any extent here. It must suffice in this place to note the fact that but one leaf springs from the same point on the stem, and there are primarily two systems of arrangement, as follows:

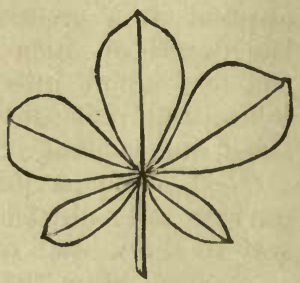

FIG. 18.

Alternate, when the leaves spring one from a joint - or node, as it is called - and alternately from opposite sides of the shoot. (Fig. 19.)

Fig. 17. A Pinnately compound Ieaf.

Fig. 18. A Palmately compound Leaf. 
Opposite, when the leaves spring two from a joint, and on directly opposite sides; - arranged along the stem in a manner similar to the arrangement of the leaflets along the rachis of the compound leaf shown in Fig. 1\%. A form of this type is the whorled arrangement, where there are more than two leaves from a single joint. 'They are then disposed at equal distances from each other in a whorl or cirele around the stem.

44. In the Pine, the Lareh, etc., we find leaves which are needle-shaped. They are arranged in fascicles or bundles, and, at first thought, seem to violate the law that only one leaf springs from the same point, but that is not the case. They are really arranged according to the established

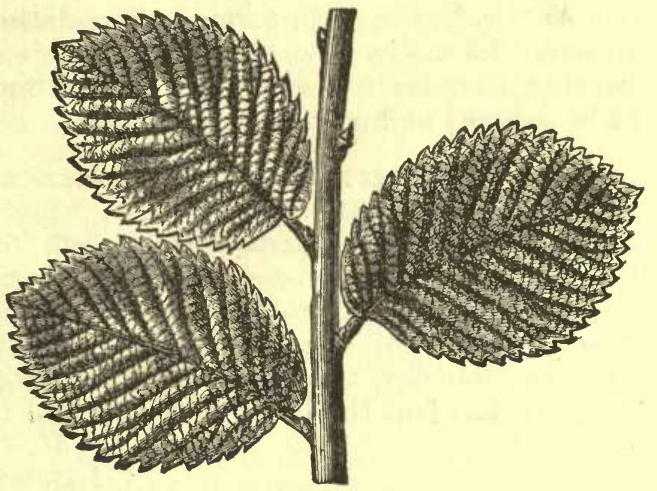

FIG. 19.

laws, but along very short and undeveloped branchlets, and so crowded together as to appear in clusters. (Fig. 20.)

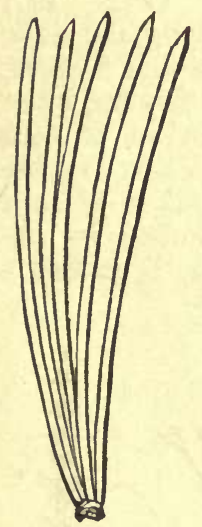

FIG. 20.

45. The foliage of Pines is curious, in that there are two sorts of leaves:-(1) the primary leaves which are scale-like and fall away early, and from their axils appear (2) the secondary leaves, much larger, more conspieuous and arranged in fascicles as above described.

46. Vernation is a term denoting the arrangement of the leaves in the bud. It is a subject of importance in its place, but we will not devote space to it here. The few terms which may occur relating to it will be explained in the Glossary.

\section{INFLORESCENCE.}

4\%. This term (from L. in, upon, and floreo, to flower) is applied to the situation and arrangement of the flowers on a plant, and various as this at first may seem to be, it is all reducible to an easy system of classification. The location of every flower is determined by the same laws which apply to the arrangement of the leaves, and only in those places do they appear. They develop from buds which, in early stages, are indistinguishable from leaf-buds, and like them are either terminal or axillary.

48. When a bud develops a single flower, the latter is spoken of as solitary, and the stalk supporting it is its peduncle. In case of a cluster of flowers supported by a common stalk, that stalk is called a peduncle, and each branchlet supporting a flower is called a pedicel. A flower is

Fig. 19. Leaves of the Red Elm, showing "alternate" arrangement. (From Hough's Elements of Forestry.)

Fig. 20. Fascicle of Needle-shaped Leaves of the Pine. (From Hough's Elements of Forestry.) 
said to be sescile when it has no perduncle - i. e., when it is seated close to the stem of the plant.

49. 'The leaves of a flower choster are usually very much rednced in form - often mere sales. They are then called liracts when on the petiole. and when on its branches, bractlets. In a broader sense - bract" refers to both forms. Sometimes the bracts are wanting altowether. In catse al flower appears in cateh axil of leaves which regularly derelop. they are not spolien of as forming a flower-cluster, but are said to be sulitary and axillary.

50. An Indeterminate Inflorescence is the one formed when the flowers appear from axillary huts, while the terminal but continues developing leaves and prolonging indelinitely the common axis. In this form the blossoming commences below and progresses upward - is satel to be asending - the older buts developing their flower's fisst, and in (ato their pediecls are considerably prolonged, so as to malie a broad flat flower-chuster, the onter flowers develop before the central ones.

From that fact the inflorescence is sald to be centripetal.

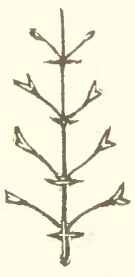

Riteritis

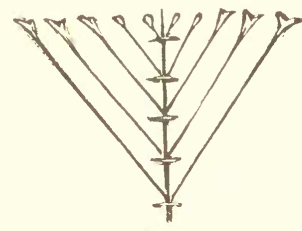

(irrint).

51. The principal forms of the Indeterminate Infloreseence are the following:

5.) if Receme, when the flowers are arranged singly along a common axis, ancl furmished with pedicels of about equal length. (Fig. 21.) sumetimes the buts along the axis, insteat of developing single flowers, develop little racemes of flowers, when the whole cluster is spolien of as a compoumel receme. When rather irrerrularly eompound, as in the Catalpat, (lat, ete, it is spoken of as a manicle, and a comprat pramial form of this, as presenter by the flower-chuster of the Iorse-chestmut or a bunch of gratpes, is called a thyisus.

53. I corymb diflers from a raceme in having the lower pelictes longer, so ats ta raise their flowers nearly or quite to the level of the npuermost. (Fir. 2.).)

d) An lembel is a eluster where the perticels are all prolomgerl, and grow all from the summit of the perlumele. (Fig. 283.) They are here callexl rely, and alle often subtenderl by a whorl of bracts, ralled an involucere. In the componed "rmelel cach ray supports, instram of a

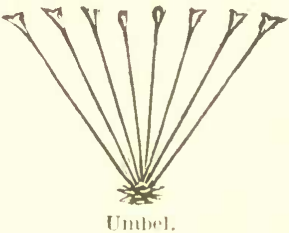

FII, 2?

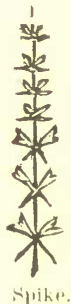

Fili. 24

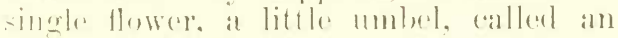

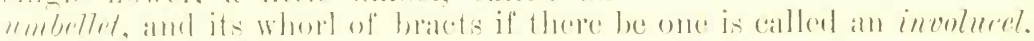

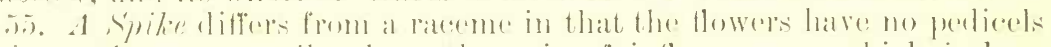

i. a., they ales sessile alome the axis of inflorescence, which is here

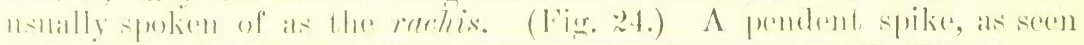


in the Poplar, etc., is called a catkin or amont. A thick fleshy spike is called a spadix, and this is often furnished with imperfect flowers, and surrounded by a peculiar enveloping sheath, called a spathe; as seen in the Calla, Indian 'Turnip, etc., or the spadix may be naked as in the Cat-tail Flag ('Typha).

56. A Head is a form of inflorescence where the flowers are sessile and springing all from a very short and somewhat enlarged axis, known as the receptacle. 'The Button-ball, Button-bush, etc., afford familiar' examples. Sometimes the head is subtended by a whorl of bracts, called. here also an involucre, as seen in the Dandelion, etc.

5\%. Determinate Inflorescence is a form where the flowers appear from terminal buds; consequently the further growth of the axis in that direction there terminates. Should there be a single flower it is spoken of as terminal and solitary. When there is a cluster of flowers the order of blessoming is just the reverse of what we saw in the indeterminate type. It is descending, i. e., the uppermost flowers develop first and the lower ones later. When they form a broad and flat flowercluster, those in the center open first and the outer ones later. Hence it is said to be centrifugal in order of development. The cluster is spoken of as

58. A Cyme - the first flower appearing from the terminal bud, and then at the ends of naked or bracted shoots from the nearest axillary buds; then from the next lower and so on. (Fig. 25.) The simplest form is just the reverse of a simple raceme. (Compare Figs. 21 and 25.) When the branching continues further it becomes a compound cyme. (Fig. 26.)

59. A Fascicle is a cyme where the flowers appear in a close cluster or bundle, as the origin of the name-L. fasciculus, a little bundle - indicates, and

60. A Glomerule is a cyme where the flowers appear in a sort of head. These forms may be recognized by their centrifugal order of blossoming.

61. Some plants represent both the determinate and the inde- Cyme. terminate systems of inflorescence, by having the flowers arranged

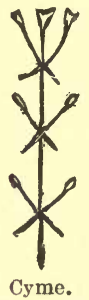

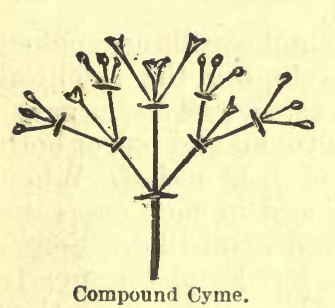

FIG. 26. in the clusters of one system and these clusters developing in the order of the other. But both systems are seldom, if ever, represented primarily in one cluster; i. e., plants rarely, if ever, produce flowers from both terminal and axillary buds.

\section{The Flower.}

62. The object of the flower, in vegetable economy, is the production of seed for the perpetuation of the species. In its complete form it consists of four parts, called the organs of the flower. They are the calyx, corolla, stamen and pistil.

63. Strange as it may seem at first thought, these parts, however peculiar in form or in color, are nothing more nor less than altered leaves, differentiated for the special purpose of reproduction. 
Considering them, therefore, as leaves arranged in whorls on a base or short thickened axis - called the receptacle - let us look into the arrangement of a simple typical flower,- one in which all the parts are present and in the simplest form. We will commence our examination below and work upwards.

64. The Calyx is the lowest or outermost whorl of the leaves of the flower. (Fig. 2\%a.) It is usually green in color, but not always, and its principal function seems to be the protection of the parts within, especially while developing in the bud. Its parts may be united by their edges, forming a tube, or separate, in which ease they are called sepals.

65. The Corolla is the whorl next above or interior to the calyx (Fig. 27b), and is usually of more delicate structure, and of some other color than green. Its parts may be separate, when they are ealled petals, or they may be united by their edges, when the flower is spoken of as monopetalous, in distinction from polypetalous. Again, they may be very dissimilar in shape and size, when the corolla is said to be irregular. It is usually easily recognized by its delicate structure and high coloring. Sometimes the corolla is wanting, when the flower is said to be apetalous.

66. The functions of the corolla are probably two-fold;- protection to a certain extent to the parts interior to it, and, it would seem prineipally, attraction by means of its bright colors for insects and humming birds, which in the grand economy of nature are the pollen-bearers

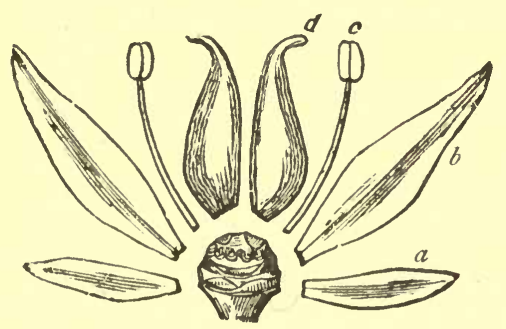

FIG. 27. - miniature match-makers in reality - for all of the brightly colored or fragrant flowers. It would be interesting in this connection to notice how nicely flowers are formed with reference to that particular end - i. e., for insuring cross-fertilization through the agency of these tiny messengers wholly unconscious of the part they are playing. But that the reader must learn elsewhere or see for himself in the field.

$6 \%$. The calyx and corolla are spoken of as the perianth, or, from the fact of their enveloping the essential organs, as the floral envelopes. They are considered as unessential organs, beeause the elements of reproduction do not occur in them, and one or both are often absent. In the latter case the flower is said to be naked. When only one is absent that is considered as the corolla, and in such cases the remaining ealyx is very commonly highly colored and petal-like. Sometimes when both are present they are both highly eolored and very nearly alike. Rarely as in the marginal flowers of the Hydrangea, ete., they constitute all there is to the flower, i. e., the essential organs are absent, and such flowers are from that fact neutral.

68. The Stamens sometimes spoken of collectively as the Androecium, constitute the whorl next above or interior to the corolla, and so

Fig. 27. Parts of a Flower detached from the receptacle, but relative positions maintained, $a$, sepal- one of the leaves of the calyx; $b$, petal-one of the leaves of the corolla; $c$, stamen; $d$, pistil. (From Gray.) 
differentiated are they as to lose all semblance of leaves (Fig. 26c). A stamen consists of two parts: a stalk-like portion (Fig. 28a), called the filament and an end or head (b), which is the anther. The anther commonly consists of two cells - miniature cases - which open at the proper season, each usually by a longitudinal slit, to liberate their contents a very fine, golden yellow powder.

69. This is the pollen, which is to perform a very important function, the fertilization of the ovule in order that it may become a seed. Although to the unaided eye it is a mere powder, under the microscope it is shown to be a mass of symmetrical bodies, usually spherical but sometimes elongated, cubical, triangular etc., and often beantifully marked with bands, checks, sjines, etc., in fantastic figures of endless diversity, but always constant in the same species. One form of pollen grain is shown in Fig. 42-16, $1 \%$.

70. The Insertion of the Stamens is usually the same as that of the corolla, and they are said to be hypogenous, when they are inserted beneath the ovary, as in Figs. 41-2, 6; perigynous, when around the ovary on the calyx-tube, the ovary itself being free, as in Fig. 29; epigynous, when on the top of the ovary, or on the calyx-tube adherent to the ovary to that point.

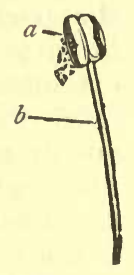

FIG. 28. An example of the last type is seen in the apple blossom. The stamens are called epipetalous, when inserted on the corolla, as in most monopetalous flowers.

71. The Union of the Stamens with each other may be by means of their filaments or anthers, and when no union at all exists, they are said to be

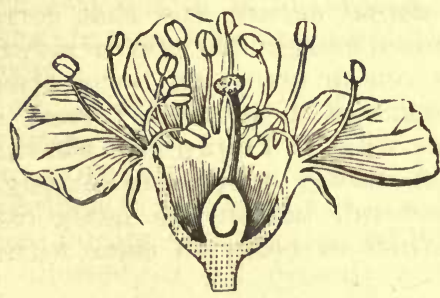

FIG. 29. distinct. United by their filaments they are monadelphous (from Greek words signifying a single brotherhood), when united in one set so as to form a tube or ring; diadelphous (two brotherhoods), when united into two sets, and so on; polyadelphous when in many sets. When the stamens are united by their anthers, they are said to be syngenesious (from Greek $\sigma v v$, together, and $\gamma \varepsilon \dot{v} v \varepsilon \sigma \imath$, birth.) 72. The Attachment of the Anther to the Filament is important. The anther is said to be innate when it is seated, as it were, on the end of the filament; adnate, when the lobes are attached, throughout nearly or quite their whole length, to the opposite sides of the filament. T'Te portion of the filament between the anther-cells is called the connective. A versatile anther is one balanced at abont its center across the tip of the filament and upon which it turns.

73. The Dehiscence of the Anther (L. dehisco, to gape or yawn) is the opening of the cells, for the discharge of its pollen. It is usually by a vertical slit in each cell extending their full length, but in some elasses of plants it is by a chink, a terminal pore or a lid. When they open on the side towards the pistil they are introrse, and when away from it extrorse.

Fig. 28. Stamen, $a$, filament and, $b$, anther with escaping grains of pollen. (From Gray.)

Fig. 29. Flower of the cherry, cut through lengthwise. (From Gray.) 
74. The Pistil is the uppermost or innermost of the floral whorls, sometimes spoken of collectively as the gynoecium, and here, too, we see but very little if any resemblance to leaves. There may be one or several pistils, and these distinet or united.

75. A perfect pistil consists of three parts. The ovary is its basal portion and within this are the ovules, ${ }^{*}$ one or many, which after fertilization develop into seeds. The style is the part of the pistil next above the ovary - a sort of neck connecting it with the part above, called the stigma. It may be long and filamentons, short and thick, or eren wanting altogether when the stigma is said to be sessile. 'The stigma is the portion of the pistil specialized to receive the pollen, that it may fertilize the ovule. It forms the end of the style, but not infrequently extends down its side, when the style is spoken of as stigmatic down its side.

76. Pistils are simple or compound, according as they are made up of one or more leaves - pistil-leaves or carpel-leaves as they are called, the word carpel meaning a simple pistil or one of the component parts of a compound pistil. lit is most commonly used in the latter signification. Often there is not the slightest resemblance in them to leaves, but an extended study of the different forms would show that they are withont doubt altered leaves, and our simplest way of considering them is on that supposition.

7\%. A Simple Pistil is formed from a single leaf folded along the midrib and the margins brought together, the upper side in, thus making a single celled ovary, a single style, and, as a rule, a single stigma - but the latter may consist of two lobes or erests instead of

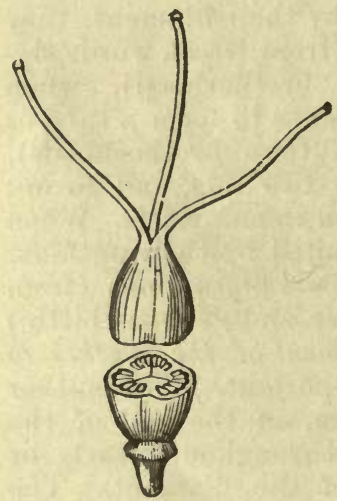

FIG. 30. being simple. The line eorresponding to the midrib is called the dorsal suture, and that corresponding to the united margins the ventral suture.

78. The ovules, one or many, are borne along the united margins, and these, often turned in quite a little, from what is known as a placenta (pl. placent(e). A flower may have a single simple pistil or several, but in the latter case they must be distinct in order to come within the definition.

79. A Compound Pistil is formed from two or more carpel leaves united by their edges, and its compound nature is shown by the several cells of its ovary, and its several styles or stigmas - one or all. From this definition we see the degree of union is very variable. It may be only at the base, so that at a casual glance the carpels may seem to be so many simple pistıls. Then, a fnither union is seen (Fig. 30) where only the styles and stigmas are distinct. A still further union is found in the pistil of the Bass-wood (Figs. 41$4,6)$, where, externally, only a five-lobed stigma suggests its compound nature, the style being single and the ovary apparently, but this in section is shown to be distinctly five-celled.

\footnotetext{
* For terms descriptive of the parts, kinds and positions of the ovule, see 101-105.

Fig. 30. Pistil of the St Johnswort, shown to be compound by its three styles and three cells of the ovary. (From Gray.)
} 
80. The degree of the partitioning of a compound ovary into cells is also variable. When the united edges of the carpel leaves do not turn in far, and bear their ovules along the lines thus formed (placentæ), on the walls of the common cell, the ovules are said to be borne on parietal placentae (from L. paries a wall).

81. Passing now many intermediate grades, we find pistils (Figs. 41$4,5)$, where the infolding extends to the center or axis of the ovary, making a number of distinct cells by complete partitions (called dissepiments); - or in other words, the pistil seems to be made up by the union along their sides of so many closed carpels. In these the ovules are of course borne along the inner or central sutures, and they are said to be on axial placentce.

8*. Cases are found (Fig. 31), in which the partitions have entirely disappeared, and the ovules are then borne upon a post or column in the center of the ovary, and they are said to be on a free axial or central placenta, and the ovary is plainly onecelled. However, the compound nature of such pistils is readily seen by the number of styles or stigmas.

83. The forms of pistils considered above are closed pistils, and they characterize the sub-class of Flowering Plants known as Angiosperms (Greek, $\alpha y \gamma \varepsilon \tilde{o} o v$ and $\sigma \pi \varepsilon \dot{\varepsilon} \rho \alpha$, enclosed seed). 'The only way the pollen can reach the

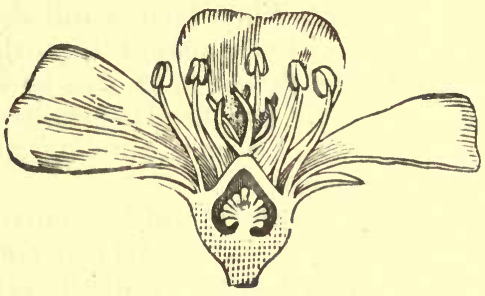

Fig. 31. enclosed ovules is by sending out very minute tubes, which penetrate through the stigma and down the style to them. Another form of pistil is

84. The Open Pistil. In this the carpel leaf instead of folding together remains open, in the form of a scale, and bears two or more ovules on the upper (inner) surface near the base. These scales grow imbricated together in a close spike - cone - as seen in the representatives of the Pine family. At the time of flowering they are divergent, and the pollen is allowed to fall directly onto the exposed ovules. 'The scales then close together and remain so until the seeds mature, when they open and liberate them.

85. This form of pistil characterizes the remaining sub-class of Flowering Plants, viz., the Gymnosperms (Greek, $\gamma v \mu v o s$, naked, and $\sigma \pi \varepsilon \varepsilon_{\rho} \mu \alpha$, seed).

86. We have now found, as shown in the foregoing pages, the two parts - pollen and ovule - for the production and bringing together of which all the parts of the flower are subservient. The organs which produce them - stamens and pistils - are called the essential organs, because they are essential for the propagation of the species, and must always exist either in the same or separate flowers. It remains for us to consider certain

\section{Terms of More General Application to the Parts of the} Flower. In our type flower, shown diagrammatically in Fig. $2 \%$,

Fig. 31. Flower of the Purslane cut through lengthwise. (From Gray.) 
we have the different sets of organs entirely separate from each other. From this they are said to be free.

88. But they are often inseparably joined or consolidated to a certain extent with each other, when they are said to be adnate or adherent. In Fig. 29, the corolla and stamens are shown to be adnate to the calyx, up to a certain point - in other words they are inserted on the calyx while the pistil is free. In this the ovary is superior-because it is superior to the insertion of the calyx - or what is the same thing, the calyx is inferior.

89. In Fig. 31 there is shown adhesion of the calyx (and, of course, of the corolla and stamens also), with the lower half of the ovary; whence the ovary is said to be half-superior or the calyx half-inferior. Still another grade of adhesion is seen in the Apple blossom, where it extends the whole length of the ovary, and the ovary is wholly inferior or the calyx superior. .

90. Perfect is a term applied to a blossom, in which both stamens and pistil, i. e., both sets of essential organs, are present. When one set is lacking the flower is said to be imperfect, and in this connection the following terms are used; - staminate, sterile or male, when the flower has stamens and no pistil; and pistilate, fertile, or female, when it has a pistil and no stamens.

91. When the staminate and pistilate flowers grow on separate plants, the species is said to be dicecious (from Greek dits and oinz', dwelling separately); and when on the same plant, but in different flowers, monoecious (from Greek, - in a single dwelling). The word diclinous (from Greek,- to incline in two ways), is applied to the flowers of both of the above classes. Sometimes both perfect and imperfect flowers are found on the same plant when it is spoken of as polygamous.

92. Complete is a term which designates that all of the four sets of organs - calyx, corolla, stamens and pistil - are present. When a set is lacking, the flower is said to be incomplete.

93. Regular is a term designating that all the organs of the same kind are alike in size and shape; otherwise the flower is said to be irregular, as seen in the Pea, the Violet, etc. When the parts which constitute a set are separate from each other they are said to be distinct; otherwise, united or coherent.

94. Symmetrical is a term which designates that there is the same number of parts in each set of organs: and this suggests the consideration of

95. The Numerical Plan of the Flower. It is found upon counting the parts of the varions sets of organs in a flower, that the same number is quite constant throughont, although to this rule there are numerous exceptions. When there are five sepals we commonly find five petals, five (or ten, i. e., two sets of five each) stamens and five ovarycells or styles. Five is here said to be its numerical plan. In other flowers we would find three and then again four as the numerical plan.

96. Aestivation is a term meaning the arrangement of the parts in the flower-bud; just as vernation has reference to the arrangement of the leaves in the leaf-bud. Such terms relating to this subject as we have occasion to use will be explained in the Glossary. 


\section{The Fruit.}

97. The Fruit is the ripened ovary with its contents, and with the calyx-tube when this is consolidated with it as conspicuously in the Apple, the Pear, etc. Our definition shows that the word "fruit" in technical language does not exactly coincide with its meaning in common use. For example, the Strawberry, a delicious "fruit," in common language, consists principally of an enlarged fleshy receptacle, no fruit at all in technical language, while the true fruit is the numerous small ripened ovaries, each with a single seed, which cover its surface and could hardly be thought of as even edible.

98. The ripened wall of the ovary, with the adnate part of the calyx, if any, is called the pericarp, and in process of Fir. 32. maturing it may remain thin and $d r y$ or may change greatly

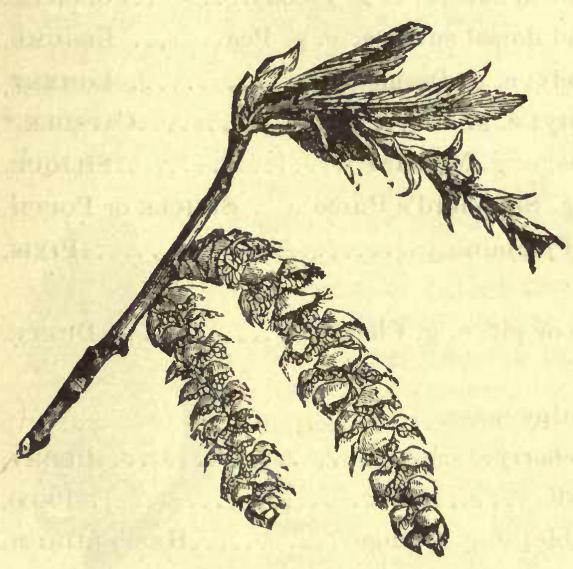

Fig. 33. by becoming thick, pulpy and juicy - when it is said to be fleshy - or part may become fleshy and the rest hard as seen in the Peach, Cherry, etc. In these cases, where the pericarp is distinctly divisible into two parts, the outer or fleshy part is called the exocarp, and the inner or hard part the endocarp or epicarp, which is the stone or pit, and within this the "kernel" is the seed proper.

99. When the pericarp opens at maturity to liberate the seeds, it is said to be dehiscent - in distinction from those that are indehiscent, or do not thus open;and when the dehiscence is along a suture or partition it is said to be septicidal, or, when midway between the sutures, loculicidal. Circumcissile is a mode of dehiscence which is transversely around the pericarp.

100. Fruits are free or aggregated, according as they are formed by the ripening of respectively, a single (either simple or compound) pistil or an aggregation of pistils. The varieties found are quite numerous, and the most important are shown in the following:

Fig. 32. Scale from a Pine cone, showing the two winged seeds attached to its inner (upper) surface. (From Hough's Elements of Forestry.)

Fig. 33. Flowers of the Hornbearn, the two lower catkıns being staminate and the upper one pistillate. (From Hough's Elements of Forestry.) 


\section{Synopsis of the Principal Kinds of Fruits.}

Free Fruits - resulting from the ripening of a single pistil, either simple or compound.

a. Dry Pericarp,

b. Indehiscent and

c. Thin, containing a single ovule; e. g. Buttercup............... AcheNiUM.

An achenium inflated and bladder like e. g. Pigweed......... Utricle.

An achenium with pericarp adherent to seed; e. g. Wheat....... CARYoPsis.

An achenium with wing-like projections; e. g. Ash and Elm....... Samara.

cc. Thick, hard and furnished with an involucre or cup; e. g. Oak........NuT.

bb. Dehiscent Pericarp,

c. Resulting from a simple ovary.

Dehiscent along the inner or ventral suture; e. g. Poony......... Follicle.

Dehiscent along both ventral and dorsal sutures; e. g. Pea....... LEGUME.

A Legume dividing transversely; e. g. Desmodium.............Loment.

cc. Resulting from a compound ovary; e. g. Iris............................

Dehiscence by two lateral valves; e. g. Mustard............... Silique.

A broad and short silique; e. g. Shepherd's Purse ..... Silicle or Pouch.

Dehiscence circumcissile; e. g. Plantain ........................

aa. Fleshy and Indehiscent Pericarp.

b. With hardened endocarp - a stone or pit; e. g. Cherry.............. DRuPE.

bb. Without a hardened endocarp.

c. Seeds distributed through the pulpy mass.

Rind membraneous; e. g. Gooseberry...........................

Rind firm and hard; e. g. Gourd........................... PEPo.

Rind leathery and easily separable; e. g. Orange............ Hesperidium.

cc. Seeds in distinct cells with papery wall;; e. g. Apple............ Pove.

aal. Fibrous or Fibro-fleshy and Indehiscent Pericarp.

b. Endocarp hardened and cell two-lobed; e. g. Butternut............ TRYмa.

Multiple or Aggregate Fruits - resulting from the ripening of an aggregation of pistils.

a. Carpels open and scale-like; e. g. Pine............... Cone or Strobil.e.

ac. Carpels closed and variously aggregated as seen in the Magnolia, Mulberry,

Osage-orange, etc..................... NOT WELL CLASSIFIED.

* "Capsule" and "Pod," in a broader sense, are often used for any free, dry, dehiscent fruit. 


\section{The SeEd.}

101. The seed is the fertilized and developed ovule, and the following terms used here for convenience as descriptive of the parts, the kinds and the positions of the ovule are also applicable to the seed, excepting, perhaps, a few changes which will be mentioned later.

102. An ovule consists of one or two coats or integuments:- an outer coat, the primine, an inner coat, the secundine, and an interior part or contents, the nucleus. At a point which marks the apex of the ovule is a minute hole - the orifice or foramen - through the integuments, and at the opposite extremity the coats are blended together and with the base of the nucleus; this is called the chalaza. The stalklet, if there be any, supporting the ovule is the funiculus, and the place of its attachment with the ovule, the place where it breaks away when a seed, is called the hilum or scar.

103. As an ovule develops, if its axis (an imaginary line passing through its center from base to apex) remains straight, in the direction of the original line of growth, it is said to be an orthotropous or straight ovule. More

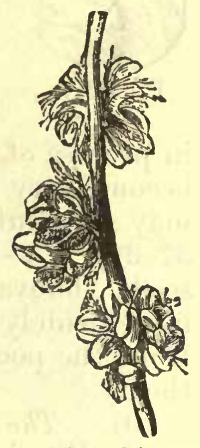

Fig. 34.

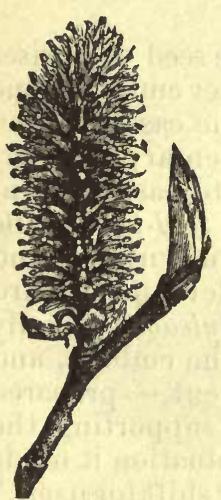

FrG. 35. commonly, however, the ovule turns more or less over upon the supporting stalklet, which becomes adherent to its surface, and that part, extending from hilum to chalaza, is called the rhaphe. It is found with the next two kinds of ovules. When the ovule is turned about half over, its axis being at right angles to the original line of growth, it is called an amphitropous or half-inverted ovule. When it is turned completely over, the axis being parallel to the original line of growth and in the opposite direction, it is said to be an anatropous or inverted ovule.

104. In the preceding cases the axis of the ovule remains straight, the flexion taking place in the supporting stalklet; but there is a form of ovule where the axis itself becomes curved, the apex and orifice being thus brought over near to the base

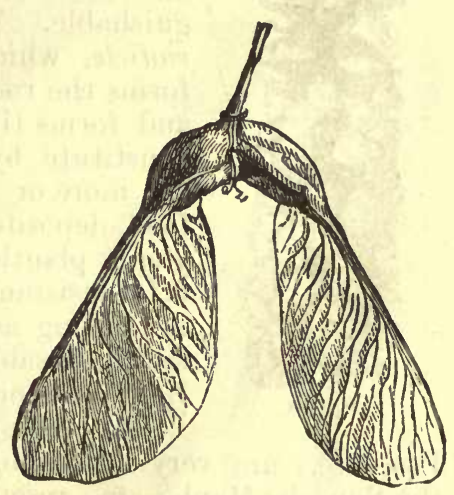

Frg. 36. and chalaza. Such an one is called a campylotropous or curved ovule, and, as with the orthotropous ovule, has no rhaphe.

105. The position or direction of the ovule in the cell is designated by the following terms:- horizontal, when growing from the side of the cell

\footnotetext{
Fig. 34. Staminate Flowers of the Oak, enlarged. (From Hough's Elements of Forestry.)

Fig. 35. Pistillate Flowers of the Willow. (From Hough's Elements of Forestry.)

Fig. 36. Fruit of the Maple (A pseudo-platanus) - a double samara. (From Hough's Elements of Forestry.)
} 
out horizontally; ascending, when growing obliquely npwards; erect, when growing from the base of the cell directly upwards; pendulous when growing from near the top of the cell; and suspended, when hanging directly from the summit of the cell.

Let us consider now more especially the Seed, as we find

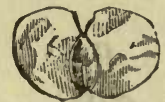

FIG. 37. it developed from the fertilized ovule. We will find that

106. The Seed Coats are commonly two, the testa and the tegmen. 'T'he testa is the outer coat, originally the primine of the ovule, and often becomes very greatly changed in process of development. It may be thin and papery, or thicken and become very hard or woody, etc., and be smooth or variously marked. It may send out membranons projections, to serve as wings, or hairs (Figs. 37-39), etc. - devices for rendering the seeds buoyant, that the wind may more widely scatter them, as they fail from the pods which open to discharge them.

10\%. The tegmen is the inner coat, originally the secundine of the ovule, and is usually thin and delicate, often hardly distinguishable from the testa.

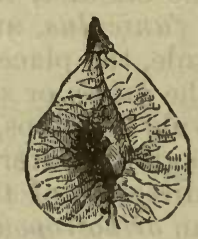

FIG. 38.

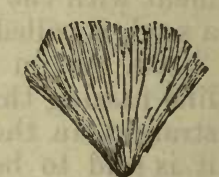

FIG. 40.

108. The Kernel or Nucleus of the seed comprises

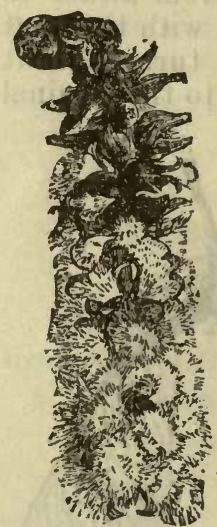

FIG. 39. all interior to its coats, and consists of either embryo alone or with an accompanying albumen as the case may be.

109. The Embryo or Germ is the rudimentary plantlet, and consists of three parts, usually quite easily distinguishable. They are the cotyledons or seed-leaves, the radicle, which in germination grows downward and forms the root, and the plumule which develops upward and forms the stem or trunk. The colyledons usually constitute by far the greater bulk of the embryo, and are more or less gorged with nourishment,-prepared food deposited there by the parent for supporting the young plantlet, when at the time of germination it needs it for assistance in taking root in order to "shift for itself." According as there are one, two or several cotyledons, seeds are said to be respectively monocotyledonous, dicotyledonous or polycotyledonous.

110. The cotyledons as seen in the Horsechestnut, Pea, etc., are very thick and seem very little litie leaves. Those of the Squash, Maple, etc., resemble leaves somewhat, and after giving up their stored food in germination rise above ground and serve as leares. In the seeds of many classes of plants the cotyledons contain but very little nourishing matter, and then

\footnotetext{
Fig. 37. Fruit of the Birch - a samara with two wings. (From Hough's Elements of Forestry.)

Fig. 38. Fruit of the Elm-a samara winged all around. (From Hough's Elements of Forestry.

Fig. 39. Pistillate catkin of the Poplar, with pods mostly open, and the matured seed ready to escape. (From Hough's Elements of Forestry.)

Fig. 40. Seed of the Cottonwood showing its hairy tuft. (From Hough's Elements of Forestry.)
} 


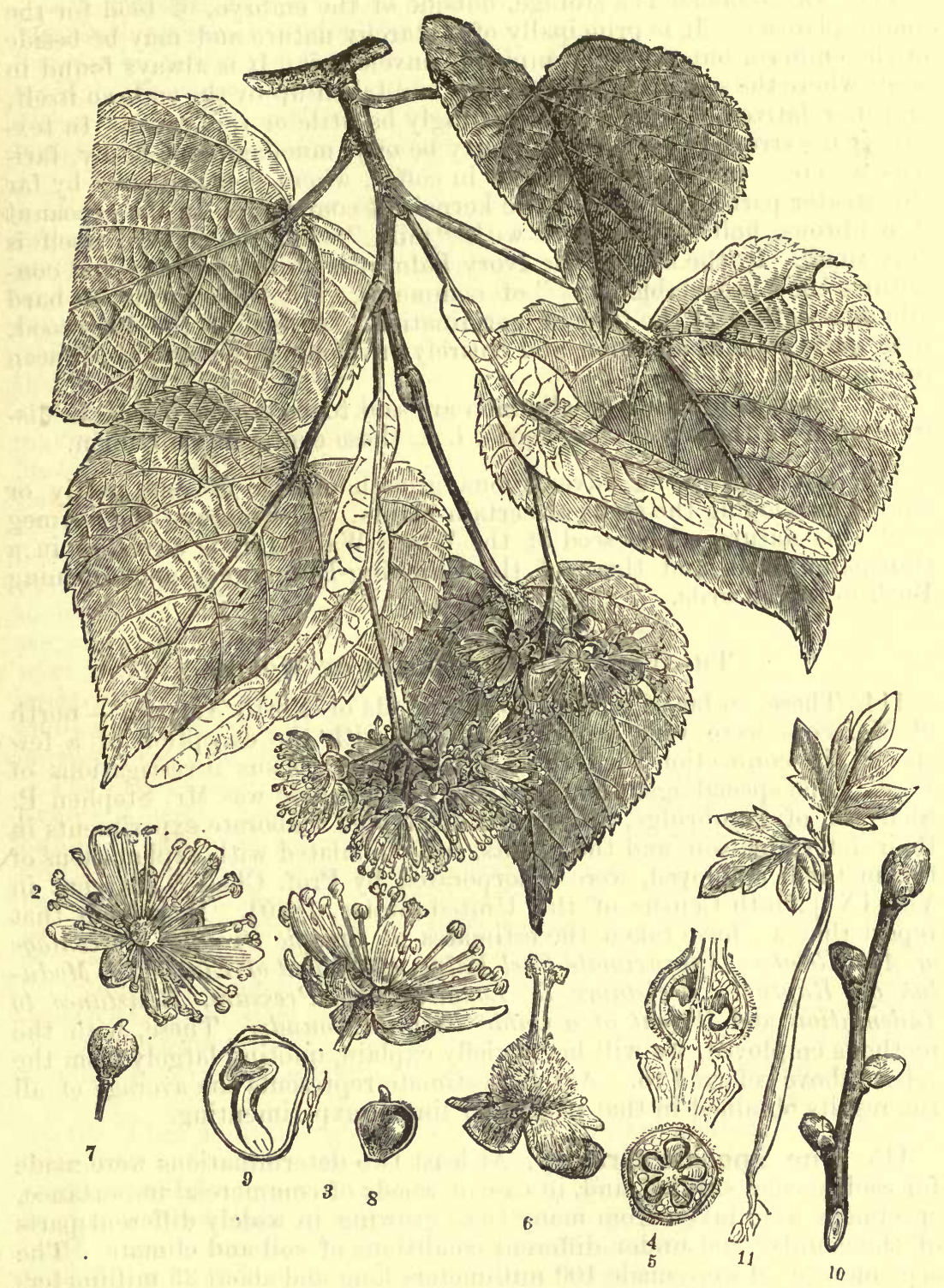

FIG. 41.

Fig. 41. Small leaved Basswood (Tilia parviflora). 1. A sprig with blossoms and leaves. 2, 3. Blossoms from upper and under points of view. 4, 5. Longitudinal and transverse sections of the pistil. 6. Pistil, exterior view. 7. Fruit. 8. Section of the same. 9. Section of the seed. 10. Twig with buds. 11. Young sprout, showing expanded seed-leaves. (From Hough's Elements of Forestry.) 
111. The albumen is a storage, ontside of the embryo, of food for the young plantlet. It is principally of a starchy nature and may be beside of the embryo, but usually completely envelops it. Jt is always found in seeds where the space and function are not taken up by the embryo itself, and its relative quantity may accordingly be little or very great. In texture it is extremely various, as it may be oily, mucilaginous, fleshy, farinaceous etc. It is quite horn. like in coffee, where it constitutes by far the greater part of the seed - the kernels of commerce. In the cocoanut it is fibrous, hollow, and filled with "milk," while the embryo itself is very small. In the seed of the Ivory Palm it is quite like ivory and constitutes the "vegetable ivory" of commerce. All these forms of hard albumen soften at the time of germination. A seed of the Basswood, with quite copious albumen and entirely enveloping the embryo, is seen in Fig. 41-9.

112. Seeds containing no albumen are said to be exalbuminous, in distinction from the albuminous seeds, i. e., those containing albumen.

113. An Aril is an adventitious growth outside of and partly or wholly enveloping the seeds of certain plants. The mace of the nutmeg is of this nature. 'The seed of the White Water-Lily is invested in a transparent aril, and those of the Climbing-Bittersweet and Burning Bush in scarlet arils.

\section{The Physical Properties of Woods.}

114. These, so far as relating to the woods of North America - north of Mexico - were very carefully studied, with the exception of a few species, in connection with the United States census investigations of 1880. The special agent employed for this purpose was Mr. Stephen P. Sharples, of Cambridge, Mass., who conducted elaborate experiments in their determination, and the results, fully tabulated with explanations of the methods employed, were incorporated by Prof. Chas. S. Sargent in Vol. IX [Ninth Census of the United States, 1880]. It is from that report that we have taken the estimates of Specific Gravity, Percentage of Ash, Relative Approximate Fuel Value, Coefficient of Elasticity, Modulus of Rupture, Resistance to Longitudinal Pressure, Resistance to Indentation and Weight of a Cubic Foot in Pounds. These, with the methods employed, we will here briefly explain, quoting largely from the report above referred to. A given estimate represents the average of all the results obtained in that particular line of experimenting.

115. The Specific Gravity. At least two determinations were made for each species studied, and, in case of woods of commercial importance, specimens were taken from many trees growing in widely different parts of the country and under different conditions of soil and climate. . The specimens used were made 100 millimeters long and about 35 millimeters square, and were dried at $100^{\circ}$ centigrade until they ceased to lose in weight. The specific gravity was then obtained by measurement with micrometer calipers and calculation from the weights of the blocks. Of the four hundred and twenty-nine species experimented upon, the range of variation was found to be from 0.2616 (in Ficus aurea, the smallfruited Fig), to 1.3020 (in Condalia ferrea, the Black Iron-wood). 
116. Percentage of Ash. 'T'wo determinations of ash were made from each specimen studied by burning small, dried blocks in a muffle furnace at a low temperature. Of the four hundred and two species studied, the range of variation was found to be from 0.08 (in Libocedrus decurrens; the Incense ('edar, and Pseudotsuga Douglasii, the Red Fir,) to 9.28 (in the Yucca elata, a kind of Spanish Bayonet).

11\%. Relative Approximate Fuel Value. The relative fuel values were obtained by deducting the percentage of ash from the specific gravity and are based on the hypothesis that the real value of the combustible material in all woods is the same. It appears from Mr. Sharples' experiments that resinous woods give upwards of 12 per cent more heat from equal weights burned than non-resinous woods. In ordinary practice, however, less heat is derived, because so much more carbon escapes unconsumed in the form of smoke than with the non-resinous woods. But, making the distinction of resinous and non-resinous woods, the amount of heat derived is very nearly in direct proportion to the specific gravity, $i$. $e$, the heavier the wood the greater the amount of heat obtained, supposing, of course, the woods to be equally seasoned. 'There is always more or less heat lost in combustion, besides that resulting from the escape of the carbon and hydrogen of the smoke. A certain amount is required to evaporate the water which is always present-ordinarily in the proportion of 25 per cent or more - in air-dried wood. These items of loss were eliminated in Mr. S.'s experiments so that his results show only approximately the amount of heat derived in ordinary practice. The amount of ash present in a wood lessens proportionally the amount of derived heat, but this item is usually very slight.

The unit of fuel value would be represented by a wood free from ash (which is not found in reality) and a specific gravity of 1 . Of the four hundred and thirty species experimented upon, there was found a variation from 0.2480 (in Yucca baccata, the Spanish Bayonet) to 1.1938 (in Condatia ferrea, the Black Iron-wood). The relative fuel value of any particular wood multiplied by 4000 wonld give very nearly the amount of heat obtained by burning a cubic decimeter of that wood - a unit of heat being the amount required to raise a kilogram of water one degree centigrade ; and 4000 units being the amount of heat produced by burning a kilogram of dry non-resinous wood. With resinous woods the amount lost in the smoke - 12 per cent or more - must be considered.

118. The Elasticity of Woods was experimented upon by $\mathrm{Mr}$. Sharples, and this he represents by designating the Coefficient of Elasticity, which is the ratio of the force required in distorting the wood to the amount of that distortion, which must not be beyond the elastic limit. By distortion is meant either extension or compression, which are both brought into play in the process of bending. The coefficient of elasticity, as determined by Mr. S., represents the weight in kilograms which would be sufficient to elongate a stick one centimeter square to double its original length, were that possible, which, of course, is not the case, as the fiber would part long before that limit is reached, but it is a convenient method of comparison. The experiments on three hundred and ten species of our native timbers shows a range in coefficient 
of elasticity from 25699 (in Ficus aurea, the Small-fruited Fig,) to 165810 (in Larix occidentalis, the Western Tamarack).

119. The Modulus of Rupture, as defined by Prof. Thurston,* is " the quantity which represents the stress upon a unit of area of crosssection of the fiber farthest from the nentral axis $\left[i . e_{.}\right.$, the line of particles not subjected to either tensile or compressive stress] on the side which gives way, and at the instant of breaking under transverse stress." This is expressed in the results of Mr. Sharples' experiments in kilograms, the unit of area of cross-section being a square centimeter. In the three hundred and ten species experimented upon, he found the range to be from 148 (in Bursera gummifera, the Gumbo Limbo,) to 1394 (in Carya myristicaeformis, the Nutmeg Hickory).

120. Resistance to Longitudinal Pressure is represented by the number of kilograms required to crush the fibers of a stick one centimeter square by longitudinal pressure. It is the ultimate weight which a stick of that size will support, and in the three hundred and seventeen species experimented upon, the range of variation was found to be from 155 (in Bursera gummifera, the Gumbo Limbo,) to 887 (in Eugenia buxifolia, the Spanish Stopper).

121. Resistance to Indentation is expressed in the number of kilograms required to sink a punch one centimeter square to the depth of $1.2 \%$ millimeters perpendicularly to the fibers of the wood, $i . e$., into the side of the grain. Three hundred and fourteen species were tested, and in them the range of variation was found to be from 47 (in Bursera gummifera, the Gumbo Limbo,) to 793 (in Guaiacum sanctum, the Lignumvitæ).

122. The word "compact," as applied to timbers by Prof. Sargent in the report above referred to, designates a non-liability to check in seasoning. It is mainly upon the authority of that report that the term is used in this work.

* The Materials of Engineering. By Robert H. Thurston. Part I, p. 94. 
1
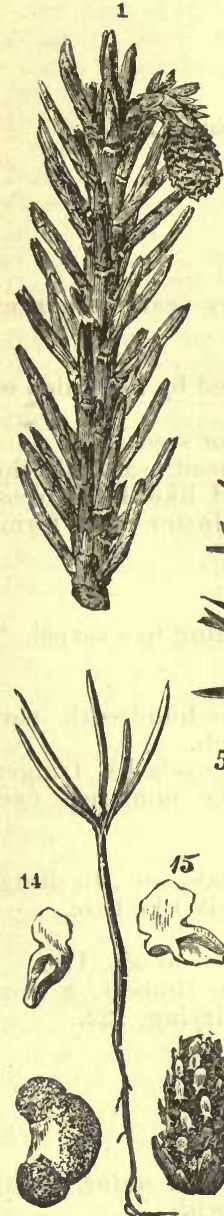

6

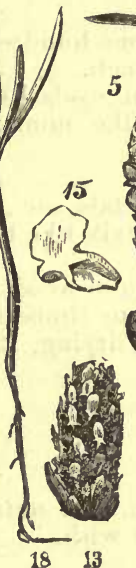

5
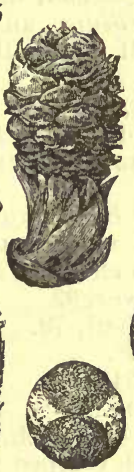

I7

2
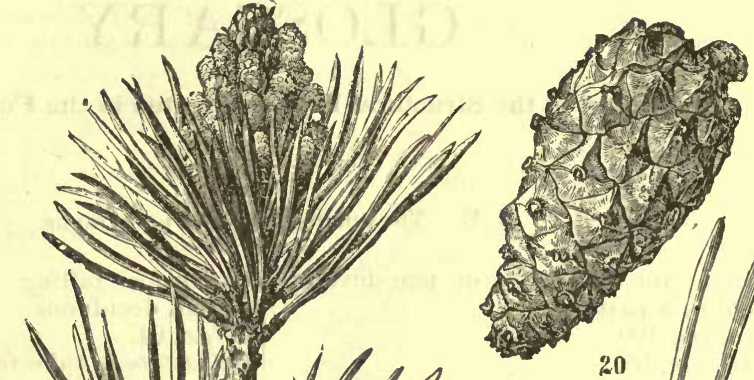

2. 1070

1.

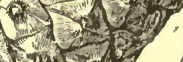

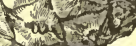
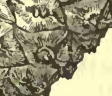

20

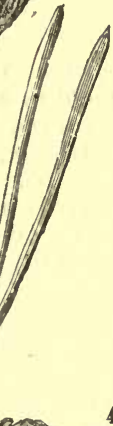

4

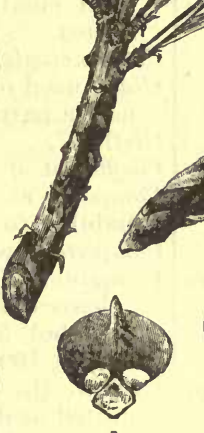

8

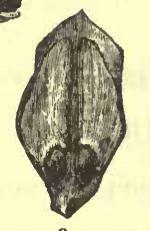

9
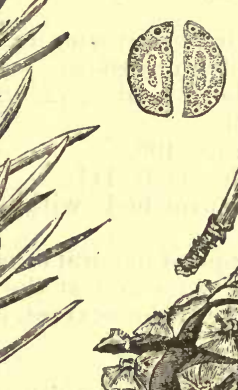

FIG. 42.

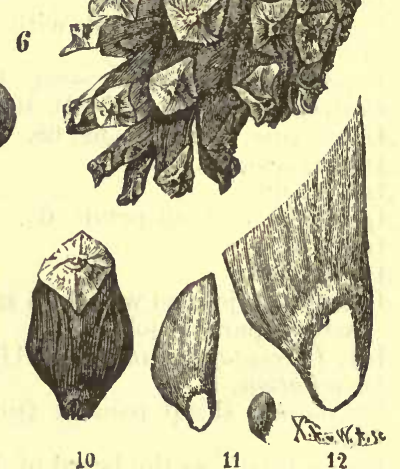

12

Fig. 42. scotch Pine (Pinus sylvestris). 1. A twig bearing pistillate flowers in is deflected spike-cone. 2. A twig bearing staminate flowers, in short oval eatkins, clustered about the tip. 3. Cone further advaneed and with seales elosed. 4. Cone matured and with scales open. 5. Cone at the period of blossoming, as in 1 , but enlarged. 6, 7. Bract and scale from same, showing outer face and side. 8. Mame, showing inner face, with its two attached ovules. 9. A scale from matured cone, inner face, showing attached seads. 10. Same, outer face, showing its thickened nature. 11, 12. Seed with its wing, natural size and enlarged. 13. Stamınate catkın, somewhat enlarged. 14, 15. Isolated stamens from same, enlarged. 16, 17, Pollen grains enlarged. 18. A young shoot, showing its whorl of seed leaves. 19. Fascicle of two leaves. 20. Transverse section of a pair of leaves, showing cellular structure and resiniferous eanals. (From Hough's Elements of Forestry.) 


\section{GLOSSARY}

\section{And Index to the Structural Botany Treated in the Foregoing Pages.}

\section{N. B.-The numbers refer to paragraphs.}

Abortion, the imperfect or non-development of a part.

Achenium, 100.

Acuminate, 35 .

Acute, 35.

Adherent, united or growing to, 35.

Adnate, closely united or growing to (literally "born with"), 72, 88.

Aestivation, 96.

Aggregate Fruits, 100.

Albumen (of the seed), 111.

Albuminous, furnished with albumen, 112.

Alternate as applied to floral organs, when those of one set stand at the intervals between those of the next set, as applied to leaves, 43.

Ament, a catkin, 55.

Amentaceous, furnished with or resem-

bling catkins.

Amphitropous (ovule or seed), 103.

Anatropous (ovule or seed), 103.

Androcium, the stamens, 68.

Angiosperm, 83.

Anther, 68.

Apetalous, without petals, 65 .

Aril, 113.

Aristate, 35.

Articulated, jointed with by a more or less easily separable joint.

Ash, Percentage of in voods, 116.

Assimilation, 17.

Aucl-shaped, sharp pointed from a broad base.

Awn, a bristle as the beard of Barley, 35.

Avned, furnished with an awn or awns.

Axil, the upper angle between the stem of a leaf and the branch or stalk which bears it.

Axillary, growing from the axil, 49.

Baccate (I. bacca, a berry), berry-like with fleshy pulp.

Berry, 100.

Bifoliate, with two leaflets, 42 .

Bipinnate, twice pinnately compound, 42.

Bract, altered, scale-like leaf of an inflorescence, 49.

Bractlet, 49.
Caducous, falling very early-earlier than deciduous.

Calyx, 64.

Calyx-tube, a tube formed by the union of the sepals, 64 .

Campylotropous (ovule or seed), 104.

Capitate, forming a liead; said of the stigma when enlarged like the head on a pin, or of a flower-cluster when forming a dense head.

Capsule, 100.

Carpel, 76.

Carpellary, of or belonging to a carpel.

Caryopsis, 100.

Catkin, 55.

Centimeter $(\mathrm{cm}$.$) , a one-hundredth part$ of a meter, $=.3937$ inch.

Ciliate (L. cilium, an eyelash), fringed with small hairs like miniature eyelashes.

Circumcissile, 99.

Clan, used of some petals, etc., to designate a narrow and stalk-like base.

Cleft, 37.

Coefficient of Elasticity in woods, 118.

Compact, as applied to timbers, a nonliability to check in drying, 122.

Complete flower, 92.

Compound pistil, 79. leaves, 38. umbel, 54

Cone, 84, 100.

Connate (L. con, with, and natus, born), united or developed with.

Connective, 72.

Cordate, heàrt-shaped, 35.

Coriaceous, leather-like in texture.

Corolla, 65.

Corymb, 53

C'otyledon, 109.

Crenate, 37.

Cuneate, or Cunciform, 34.

Cuspidate, 35.

Cyme, 58.

Deciduous, that falls away; said of leaves which fall in autumn.

Declined,turning to one side or downward.

Decompound,more than once compound, 41 . 
Decurrent (L. decurro, to run down), said of leaves when the margins of the leaf continue down along the stem below the base of nidrib.

Dehiscent, said of anthers or pods, which open to discharge their contents, 99.

Dentate, with toothed margin, $3 \%$.

Denticulnte, diminutive of dentate, $i$. e., dentate with very small teeth.

Deltoid, 34.

Diadelphous, 71.

Diclinous, 91.

Dicotyledonous, with two cotyledons, 109.

Digitate, 30, 40.

Diocious, 91.

Dissepiments, 81.

Distinct, not united with each other, 71, 93.

Divaricate, diverging in opposite directions.

Divided, as applied to leaves, 37.

Drupe, a fleshy fruit with a pit, as in the Peach and Cherry, 100.

Drupaceous, of the nature of a drupe.

Duct, 11.

Elasticity of Woods, 118.

Elliptical (leaf), 34.

Emarginate, notched at the apex, 35.

Embryo, 109.

Endocarp, 98.

Endogen or Endogenous, 16.

Entire (leaf margin), 37.

Epicarp, 98.

Epigynous, borne upon the ovary, 70.

Epipetalous, borne upon the petals, 70.

Eroded, ragged as though gnawed.

Exalbuminous, without albumen, 112.

Exocarp, 98.

Exogen or Exogenous, 14.

Exserted, projecting out, as bracts of a cone projecting beyond the scales.

Extrorse, said of anthers which open outward, 73.

Exstipulute, without stipules, 22.

Fascicle, a bundle or cluster, 44, 59 .

Fasciculate, arranged in fascicles.

Feather-veined, 29.

Fertile (flowers), those bearing the ovules, 90.

Fibro-vascular, 16.

Filament, the stalk of the stamen, 68 .

Filamentous or Filiform, threadlike.

Fleshy (fruits), 100.

Floral Envelopes, 67.

Flower, The, 62.

Numerical Plan of the, 95 .

Organs of the, 62.

Foliaceous, leaf-like in structure or functions.

Follicle, a kind of pod, 100.

Free, applied to parts of the flower, $8 \%$.
Free, applied to fruits, 100 .

Fruit, 97, 100.

Fuel Value of Woods, 117.

Germ, 109.

Gibbous, more tumid in one place than another.

Glabrous, smooth, i. e., without hairs or roughness of any kind.

Glaucous, sea-green and usually furnished with a whitish bloom, as seen on the cabbage leaf.

Globose, nearly spherical in form.

Glomarule, 60.

Gymnosperm, 85.

Gymnocium, the pistil or pistils collectively, 74.

Head (of inflorescence), 56.

Heart-roood, the inner, firmer and more durable wood of exogenous trunks. It is usually of darker color than the newer sap-wood.

Hesperidium, 100.

Hilum, the scar on a seed where the stalklet was attached, 102.

Hypogenous, growing from beneath the ovary, 70.

Imbricated, overlapping each other like shingles on a roof.

Imperfect (flowers), 90.

Incised, 37.

Inequilateral (leaves), 36.

Inferior (ovary, etc), 88

Inflorescence, and kinds of, 47-57.

Incomplete (flowers), 92.

Indehiscent, that does not open spontaneously, 99.

Innate, 72.

Introrse, 73.

Involucel, 54.

Involucellate, furnished with an involucel.

Involucre, 54, 56.

Involucrate, furnished with an involucre.

Involute, the sides rolled in in vernation.

Irregular (flowers), 93.

Jagged, 37.

Kernel (of the seed), 108.

Key fruit, a winged fruit, \& samara.

Kilogram or Kilo, a metric measure of weight; = 2 lbs., 3 oz., $4.65 \mathrm{dr}$. avoirdupois. It is the weight of a cubic deci. meter of distilled water at its greatest density.

Lacerate, torn, as it were; with deep, irregular incisions.

Laciniate, cut into long, irregular teeth.

Lanceolute, 34.

Leaf, The, 17. 
Leaf, Arrangement of, on the stem, 43.

Compound, 38.

Forms of, 38.

Forms of Base and Apex of, 35.

Forms of Margin of, 37.

Parts of the, 21.

Simple, 38.

Leaflet, 38.

Legume, 100.

Limb, the lamina or blade; the border of a calyx-tube.

Linear, 34.

Lobe, 37.

Loculicidal, 99.

Loment, 100.

\section{Medullary ray, 15.}

Meter (abbreviation, $m$.), the metric unit of length, $=39.37$ inches.

Midrib, 26.

Millimeter (abbreviation, $m m$.), a thousandth part of a meter, $=.03937$ inch.

Modulus of Rupture in woods, 119.

Monadelphous, 71.

Monocotyledionous, 109.

Monæcious, 91.

Monopetalous, 65.

Mucronate, 35.

Multiple Fruits, 100.

Nrked (Flowers), 67.

Needle-shaped (leaves), 44.

Netted-veined, 28.

Neutral (flowers), 67.

Node, 43.

Nut, 100.

Oblong, 34.

Obcordate, 35.

Oblanceolate, 34.

Oblique (leaves), 36.

Obovate, 34.

Obtuse, 35.

Opposite (leaves), 43.

Orbicular, 34.

Organs of the Flower, Essential, 86.

Orthotropous, 103.

Osmosis, 10.

Oval, 34.

Ovate, 34.

Ovary, 75

Ovoid, egg-shaped, used of solid forms, not of leaves, etc.

Ovule, 75.

Positions in ovary, 105.

Structure, 102.

Palmate, 30, 40.

Panicle, 52.

Paniculate, arranged in panicles.

Parallel-veined (leaves), 31.

Parted (leaves), 37.

Pedicel, 48.
Peduncle, 48.

Persistent, remaining on for a long time, as evergreen leaves: or sepals, which remain until the maturity of fruit.

Pepo, 100.

Perfect (flowers), 90.

Perianth, 66.

Pericarp, 98.

Perigynous, 70.

Petal, 65.

Petiolate, furnished with a petiole.

Petiole, 21.

Petiolule, 38.

Phyllotaxy, 43.

Physical Properties of Woods, 114.

Pinnate, 29, 39.

Pinnatifid, pinnately cleft.

Pistil, 74.

Closed, 83.

Open, 84 .

Pistillate (flowers), 90

Pixis, 100.

Placenta, 78.

Plaited or plicate, folded lengthwise, used of certain leaves in the bud, etc.

Plumule, 109.

Pod, 100.

Pollen, 69.

Polyadelphous, 71.

Polyandrous, having many stamens

Polycotyledonous, 109.

Polygamous, 91.

Polypetalous, 65.

Pome, 100.

Primine, 102.

Pubescent, furnished with a growth of short, soft downy hairs.

Raceme, 52.

Rachis, 38, 55 .

Radial (section), 15.

Radiate-veined, 30.

Radicle, 109.

Receptacle, 56, 63.

Regular (flower), 93.

Repand, 37.

Resistance to Longitudinal Pressure in Woods, 120.

Resistance to Indentation in Woods, 121.

Reticulated, 28.

Retuse, 35.

Revolute, rolled backward.

Rotund, 34.

Rugose, wrinkled, puckered.

Samara, 100.

Sap-wood, the newer, outside wood of exogenous trunks, usually of lighter color than the heart wood and not so durable on exposure.

Scar (of the seed), 102.

Scarious, thin, membranous and dry.

Secundine, 102. 
Seed, The, 101.

Coats, 106.

Sepal, 64.

Septicidal, 99.

Serrate, 37.

Serrulate, serrate with very fine teeth.

Sessile, 23, 48, 75.

Silver-grain, 15.

Silicle, 100.

Silique, 100.

Simple leaf, 38,- pistil, $7 \%$.

Sinuate, 37.

Sinus, 37.

Solitary (flowers), 48, 57.

Spadix, 55.

Spathe, 55.

Spatulate, 34.

Specific Gravity of Woods, 115.

Spike, 55.

Stem, The, 7.

Stamens, 68.

Insertion of the, 70.

Union of the, 71.

Staminate (flower), 90.

Sterile (flower), 90.

Stipulate, furnished with stipules.

Striated, marked with small longitudinal grooves.

Strobile, a cone, 100.

Stigma, Stigmatic, 75.

Stipule, 21.

Style, 75.

$S u b$-(a prefix), about or nearly, e. g., subspherical = nearly spherical.

Succulent, juicy, pulpy.

Superior (ovary, etc.), 88.

Symmetrical (flower), 94.

Syngenesious, 71.
Tangential (section), 15.

Taper-pointed, 35.

Tawny, a yellowish-brown or fulvous color.

Ternate, 42.

Thyrsus, 52.

Tomentose, clothed with dense wooly hairs.

Toothed (leaf-margin), 37.

Transverse (section), 15.

Trifoliate, 42.

Tripinnate, 42

Truncate, 35.

Tryma, 100.

Tumid, swollen or inflated.

Umbel, 54.

Umbellet, 54.

Undulate, 37.

Unsymmetrical (flower), a flower whose various organs do not contain the same number in each set.

Utricle, 100 .

Valvate, applied to sepals, etc., which close together like valves, the margins simply in close contact, without overlapping or folding in.

Veins (of the leaf), 26.

Venation, 27, 46.

Vernation, the arrangement of the leaves in the bud, 46.

Versatile (anther), 72.

Villous, furnished with long soft hairs.

Wavy (leaf-margin), 37.

Whorl, 43.

Wood, Structure of, 8. 


\section{A KET, BASED MAINLY UPON THE FLOWERS,}

\section{Designed as an Aid in the Identification of the Species represented in Part I.}

a. Angiospermæ - seeds in a closed ovary.

b. Polypetalous - petals present and distinct.

c. Stamens numerous, more than 10 , and calyx inferior - wholly free from the pistil or pistils.

d. Pistils numerous and cohering in a cone-like mass. (Mognoliacia.)

e. Anthers opening inward; leaves folded lengthwise in the bud (Magnolia), pointed at both ends, oval, thin and green above and below.

1. M. acuminata.

ee. Anthers opening outward and leaves folded crosswise in the bud.

2. LiRIODENDRON TULIPIFERA.

dd. Pistil solitary but compound, as shown by styles and ovary-cells; calyx valvate in the bud, deciduous (Tiliacex); stamens somewhat polydelphous (Tilia), and with 5 petal-like scales opposite the

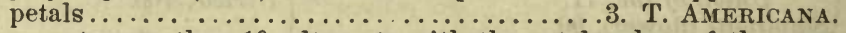

cc. Stamens few, not more than 10 , alternate with the petals when of the same number.

d. Calyx inferior - free from the ovary.

e. Ovaries 2-5, separate; stamens distinct and inserted on the receptacle; trees with pinnately compound and uniformly opaque leaves.

4. Ailanthus glandulosus.

ee. Ovary single, but compound as shown by the cells, styles or stigmas.

f. One-celled and one-seeded; styles or stigmas three; shrubs or trees with regular flowers (Anacardiacece); leaves compound with 1131 oblong lanceolate acuminate leaflets; common petiole densely villous and not winged; flowers in terminal thyrses.

5. RHUS TYPHINA.

ff. Three-celled with two ovules in each; style single; flowers irregular; stamens 6-8 (Aesculus); fruit covered with prickles, leaves palmately compound with 7 obovate leaflets..6. A. HipPoCASTANUM.

dd. Calyx superior - adnate to the ovary; flowers arranged in umbels; stamens 5; styles 5; fruit drupe-like with 5 cells each with a single ovule (Aralia); arborescent and armed with prickles.

bb. Apetalous - without petals.

8. A. SPINOSA.

c. Flowers not in catkins; pistil one, simple or compound, and the cells of ovary containing 1-2 seeds each.

d. Ovary inferior - adnate its whole length to the calyx-tube-1-celled and 1 -seeded; style 1 stigmatic down the side $(N y s s a)$; fertile peduncles bearing each two or more flowers.......9. N. MULTIFLORA.

dd. Ovary superior, - free from the calyx.

$\boldsymbol{e}$. Stipules sheathing the stem; trees with naked monœcious flowers arranged in heads............. Platanus occidentalis.

ee. Stipules not sheathing the stem, or none.

$f$. Ovules, a pair in each cell of the ovary, which becomes in g. Fruit, a double samara; leaves simple and palmately-veined (Acer); flowers appearing with the leaves in pendulous corymbs.

7. A. SACCHARINUM.

gg. Fruit, a 1-celled and 1-seeded samara (Fraxinus); flowers diøcious; calyx persistent at the terete base of the samara.

10. F. AMERICANA.

$f f$. Ovules single in each of the one or two cells of the ovary; stigmas two (Ulmacece).

g. Fruit, a 1-celled samara winged all round (Ulmus), which is without a ciliate fringe, and nearly or quite sessile; leares rough above, 
oblong, ovate, acuminate and not very unequal at the base; anthers extrorse.................... 11. U. FULVA.

gg. Fruit a drupe; leaves long taper-pointed; anthers introrse.

cc. Flowers diclinous, and one or both sorts in catkins.

12. Celtis occidentalis.

d. Only one sort (the staminate flowers), in catkins.

e. Fertile flowers, single or clustered, and fruit naked; leaves pinnately compound (Juglandacece); calyx and corolla both present in the fertile flowers and 4 parted; fruit a tryma (Juglans), which is ovate-oblong and viscid-hairy................ J. CINEREA.

ee. Fertile flowers 1-3 together, invested wholly or partly with a many. scaled involucre; leaves simple.

$f$. Involucre valveless, cup-like and only partly inclosing the one nut, $i$. e., acorn (Quercus), leaves smooth, thin, lobed with bristle-pointed lobes; acorns maturing the second year, and with involucral cup very shallow and composed of fine, closely appressed scales.

15. Q. RUBRA.

ff. Involucre 4-valved and inclosing two three-cornered nuts.

16. Fagus ferruginea.

dd. Both staminate and pistilate flowers in catkins.

$\boldsymbol{e}$. Ovary 1-celled and many-seeded; the seeds at maturity furnished with a hairy tuft (Salicacea); bracts of catkins lacerately fringed, calyx a disk-like cup; stamens 8-30; leaves broad (Populus); branchlets terete; leaves ovate-orbicular, acute and with large irregular

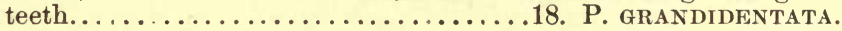

ee. Ovary 1-2-celled with a single ovule in each cell; calyx scale-like or none; stigmas 2 , filamentous; fertile flowers arranged 2 or 3 under each scale of the cone-like catkin (Betula); bark of trunk yellowish or grayish, peeling off in thin strips; fertile catkins

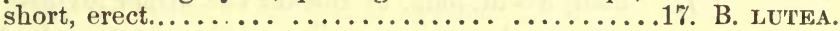

aa. Gymnospermæ - seeds naked, borne superficially on carpellary scales. Conebearing (Coniferce).

b. Scales of cone many, each in the axil of a bract and bearing 2 inverted ovules; seeds winged.

c. Leaves evergreen, fascicled; cones maturing the second year (Pinus), about half as long as the leaves, and with scales thickened at the apex but unarmed; leaves arranged in twos.........19. P. REsinosa.

cc. Leaves evergreen, scattered (not fascicled); cones with thin scales, maturing the first year (Abies).

d. Cones erect, cylindrical, large 3-4 in., and with conspicuous bracts; leaves

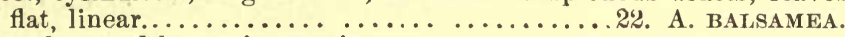

dd. Cones pendent and bracts inconspicuous.

e. Small, 8 lines or less, scales entire at tip; leaves linear.

21. A. Canadensis.

ee. Larger, 1-1 $\frac{1}{2}$ in., scales eroded at tip; leaves 4-angled.....20. A. NIGRA.

ccc. Leaves deciduous, soft, needle-shaped and in fascicles of many each; cones about 8 lines in length, scales thin (Larix) and with inflected

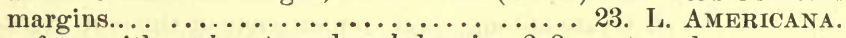

bb. Scales of cone few, without bracts and each bearing 2-8 erect ovules.

c. Flowers monocious; scales of the oblong cone dry and divergent at maturity; leaves evergreen ................ THU... OCCIDENTALIS.

cc. Flowers diœecious; scales fleshy and consolidated, making a small, dark blue, berry-like fruit; leaves scale-like and imbricated in 4 rows.

25. JUNiPERUS Virginiana. 


\section{A KEY, BASED UPON THE LEAVES,}

Designed as an Aid in Identifying the Species of this Series when out of Season for Procuring the Flowers.

N. B. - In this Key no pretension is made to exclude species not of this series, and hence it is necessary in all cases to confirm identification, by a careful comparison with the more extensive description given of the species in its proper place.

\section{a. Deciduous Leaves - falling in autumn.}

\section{b. Simple Lerives.}

c. Laminate - with well marked blade and petiole.

d. Main rib single - pinnately veined.

e. Entire or nearly so, pointed at both ends and alternate.

f. Large, 5-10 in. long and thinnish. ........ Magnolia acuminata. ff. Small, $2-5 \mathrm{in}$. long, of thicker and firmer texture.

9. NySSA MULTIFLORA.

ee. Serrate or dentate.

$f$. Inequilateral and cordate or truncate at base.

g. Ovate-orbicular, large, $4-5$ in. or more in length.

3. Thita Americana.

gg. Ovate, long, taper-pointed from a broad base.

12. Celitis occidentalis.

ggy. Ovate-obloug, very rough, especially above, rugose.

11. Ulmus Fulva.

ff. Equilateral and obtuse, rounded or only slightly cordate at base, thin and straight-veined.

g. Ovate-oblong, teeth remote, one at the end of each vein, ciliate and covered with silky white hairs......16. Fagus FERruginea.

gg. Ovate, doubly-serrate, petioles downy and of aromatic flavor.

17. BetUla i,UTEA.

ggg. Orbicular-ovate, with large, irregular teeth and long petiole.

18. Poirulds grandidentata.

eee. Pinnatifid or lobed.

f. Oval, moderately pinnatifid, lobes bristle-pointed. 15. Quercus RUBRA.

ff. Broad, truncate at both base and apex, and with two spreading lobes ou each side........... 2. Liriodendron Tulipifera. 
dd. Main ribs several - palmately-veined.

e. Ribs three at first, but soon five by branching; leaves alternate, tomentose while young; base of petiole concave and fitting over the axillary bud................. Platanus occidentalis.

ee. Ribs 5-7, from commencement; leaves opposite, smooth, base of petiole subtending (not covering) the axillary bud. .7. ACER SACCHARINUM.

cc. Needle-shaped - without distinction of blade and petiole - short, about 1 in. in length, soft and in fascicles of many each.

23. Larix Americana.

bb. Compound Leaves.

c. Palmate, with 7 obovate, serrate leaflets.....6. Aescolus Hippocastandm. cc. Pinnate and with an odd terminal leaflet.

d. Glabrous and petiolate.

e. Leaflets numerous, 21-41, each with one or two pairs of glandular teeth

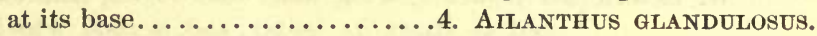

ee. Leaflets 7-9, ovate or lance-oblong, entire or very obscurely serrate. glaucous beneath............... Fraxinus Americana.

dd. Pubescent, especially along the petioles and rachis; leaflets sessile.

$\boldsymbol{e}$. Leaflets ovate-lanceolate, finely serrate; pubescence of short, rust-colored, clammy hairs..................... JugLANS CINEREA.

ee. Leaflets lanceolate-oblong, coarsely serrate; pubescence of copious, longer and whiter hairs .............. RHus TYPHINA.

bbb. Decompound Leaves and very large, with ovate, sessile, serrate leaflets and

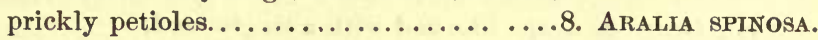

aa. Evergreen Leaves - remaining on over winter.

b. Needle-shaped and quite stiff, pointing every way.

c. Long, $58 \mathrm{in}$., in fascicles of 2 each, a broad, membranous sheath enclosing the base of each pair.............. Pinus Resinosa.

cc. Short, 8 lines or less, scattered (not in fascicles), 4-angled, usually more or

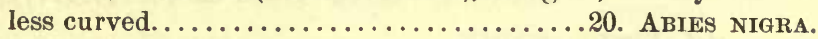

bb. Linear, small, flat and diverging in two directions.

c. Petioled, obscurely denticulate, 8 lines or less in length.

21. Abies Canadensis.

cc. Sessile, entire, 8 lines or more in length.........22. Abies balsamea.

bbb. Scale-like or awl-shaped.

c. Imbricated and closely appressed in four ranks, but making a conspicuously flat and two-edged branchlet.......24. ThuJA occidentalis.

cc. Scale-like leaves, smaller, appressed in four ranks and making a rather 4-angled than flat branchlet. Awl-shaped leaves arranged in whorls of three each.........25. Juniperus Virginiana. 


\section{A KEY, BASED UPON THE FRUIT,}

Designed as an Aid in Identifying the Species of this Series when in Season for Procuring the Fruit.

N. B. - The remarks concerning the use of the Key based upon the Leaves are equally true with reference to this.

a. Free Fruit - formed by the ripening of a single pistil either simple or compound.

b. Indehiscent pericarp.

c. Samara - dry, 1-celled, 1-seeded and with 1-2 membranous wings.

d. In terminal panicles; wing somewhat oblong-lanceolate, with a lenticular seed at about its center, and beyond which the wing is twisted

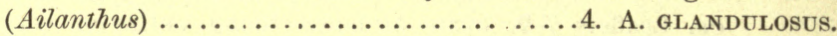

dd. In umbellate corymbs, each pedicel supporting a pair of samaræ with oblanceolate wings obtuse at the apex, and with main rib on outer

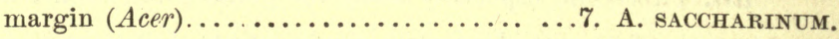

ddd. In axillary racemes or panicles, winged at the apex with a more or less lanceolate obtuse wing (Fraxinus) terete at the base - the seed

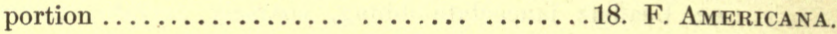

dddd. In lateral fascicles or clusters, winged all round (Ulmus) very short pedicillate, nearly orbicular and margin not ciliate. 11. U. FULVA.

cc. Drupe or drupe-like and with a single seed.

d. Fibro-fleshy and dryish pericarp.

e. Small, subglobous $(R h u s)$, in terminal thyrses and clothed with crimson acid hairs .. . . . . . . . .

ee. Large, about 2 in., with edible embryo (Juglans), ovoid or oblong, one or several together, sessile on a terminal peduncle, clothed with brownish, fragrant-viscid hairs.............. J. CINEREA.

dd. Fleshy pericarp.

e. Ovoid, with striated stone (Nyssa), bluish black, about six lines in length, usually clustered two or three together on a single axillary peduncle $\ldots \ldots \ldots \ldots \ldots \ldots \ldots \ldots . .9 .$. N. MULTIFLORA.

ee. Globular, purple, small, solitary and of sweet flavor (Celtis).

12. C. occidentails.

ccc. Drupe-like but containing more than one seed, subglobose.

d. Five-seeded and crowned with the persistent calyx-teeth and styles (Aralia), purple-black, numerous, in panicled umbels.....8. A. sPINOSA.

dd. Two to five-seeded, bluish black with white bloom, scaly bracted underneath (Juniperus)..................... J. Virgrniana.

cccc. Nut - hard, single coat, and furnished with an involucral cup or covering. 
d. Ovoid, oblong or ellipsoidal, surrounded at its base with an involucral cup (Quercus), which is shallow, saucer-shaped and composed of smooth, closely appressed scales................ Q. RUBRA.

dd. Sharply 3 -angled and in pairs, each pair invested with a 4-valved, dehiscent involucre composed of prickly scales (Fagus).

16. F. FERRUGINEA.

ddd. Short, club-shaped, surrounded with stiff hairs, tipped with the persistent recurved style and arranged in globular heads (Platanus).

13. P. occidentalis.

ccccc. Nut-like, but not invested with an involucre, globose, about as large as peas and arranged in cymes with a large, leaf-like bract attached to each peduncle $($ Tilia $) \ldots \ldots \ldots \ldots \ldots \ldots \ldots . . .3$. T. Americana.

\section{bb. Dehiscent Pericarp.}

c. Subglobose, coriaceous, dehiscent by 2-3 valves and containing one or very few large seeds with smooth, shining coat and a large scar (Aesculus); fruit prickly and leaves of 7 leafletș.

6. Aes. Hippocastanum.

cc. Sinall, ovoid-lanceolate pods arranged in catkins, opening by two valves and containing numerous seeds furnished with silky down (Populus).

18. P. GRANDIDENTATA.

al. Aggregated Fruit-composed of many carpels, either closed or open and cohering or closely massed together, forming a cone.

b. Scales of the cone open carpels (Coniferce).

c. Scales many, persistent and spreading at maturity, each subtended by a bract; ovules 2 , inverted.

d. Maturing the year after flowering (Pinus), ovate-conical, about 2 in. long, smooth, carpellary scales slightly thickened at the apex, per-

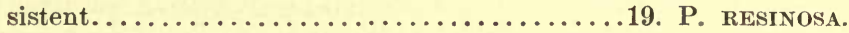

dd. Maturing the first season,- the autumn after blossoming.

e. Ovoid or oblong, 1-2 in. long, pendent; bracts inconspicuous; scales persistent on the axis, thin and with eroded tip....20. ABIEs NIGRA.

ee. Ovoid, small, 8 lines or less, pendent, scales rounded and entire at tip.

21. Abies Canadensis.

eee. Cylindrical, large, 2-4 in., erect; bracts conspicuous, exserted; scales falling from the axis at maturity........22. A Bies Balsamea.

eeee. Ovoid or roundish, small, 9 lines or less, scales persistent on the axis at maturity ........................... LARIX AMERICANA.

cc. Scales few, persistent, bractless; ovules $2-8$, erect; cone oblong with oblong, loosely imbricated scales somewhat thickened at the tip; seeds winged all round $\ldots \ldots \ldots \ldots \ldots \ldots 24$. ThuJA occidentalis.

bb. Scales 3-lobed bracts each subtending 2-3 closed, indehiscent carpels - miniature samaræ $($ Betula $) \ldots \ldots \ldots \ldots \ldots \ldots \ldots \ldots \ldots \ldots . \ldots \ldots$. B. LUTEA.

bbb. Scales closed carpels, growing from an elongated receptacle and consolidated together.

c. Dehiscent at maturity along the median line of the back, and letting ont each 1-2 berry-like seeds suspended by extensile threads (Magnotia).

cc. Indehiscent at maturity and falling away as samaræ.

1. M. ACUMinata.

\section{LiRIODENDRON TULIPIFERA}





\title{
A SYSTEMA'TIC STUDY
}

\author{
OF THE
}

\section{Species whose Woods are Represented in the Accom- PANYING SeCTIONS.}

The timbers comprised in the series, which this text is designed to accompany, belong to what are known, botanically speaking, as Flowering and Exogenous Plants. At the outset, therefore, we will, once for all, define these groups; and, as the characters herein giren are equally true of all the species enumerated in the following pages, they need not be repeated in the further definition of the various sub-groups and species.

\section{FLOWERING on PHANOGAMOUS PLANTS.}

Vegetables producing flowers which consist essentially of stamens and pistils, the latter bearing ovules or seeds.

In distinction from the Flowering. Plants are the Flowerless or Cryptogamous Plants, comprising the rest of the vegetable kingdom, from the very simply organized Slime Moulds and Bacteria up to the highly organized Ferns and Club-Mosses. But in the study of timbers this group is unimportant, as only in a few rare cases do any of its representatives attain the dimensions of trees. Those exceptions are the Tree-Ferns of tropical countries - gigantic ferns, which sometimes attain the height of fifty or sixty feet, with straight shafts quite like tree trunks and tops consisting of a bunch of enormous plume-like fronds. They, however, are of practically no value as timber.

\section{EXOGENOUS or DICOTYLEDONOUS PLANTS.}

Flowering plants whose stems consist of a central column of pith surrounded by wood in concentric layers, and this in turn by bark; the stems increasing in thickness by the addition of a new layer each year to the wood externally and to the bark internally. Leares mostly nettedveined. First leaves of the embryo (cotyledons) two and opposite, or (in the Coniferæ) several in a whorl. Parts of the flower in fours or fives, very rarely in threes. 


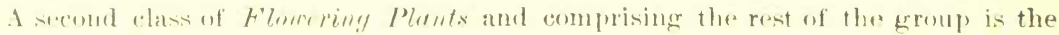

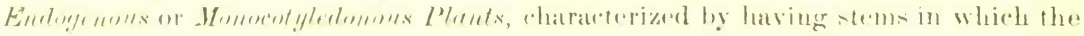

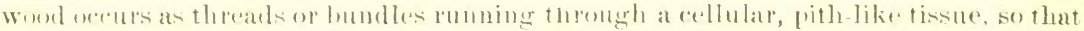

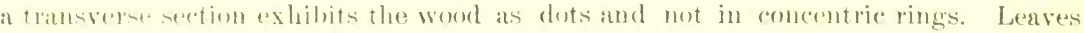
mosty patrallel peined. Embryo with single cotyledon, or rarely two, and then alter.

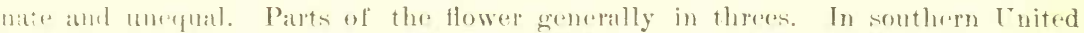
states amb elsewhere in or near the tropies trees are fouvd, such as the Palms, etce, which belonge to this class, but none that we have to do with at present.

Exogenoms plants ane subdivided into two well-marked gromps or subclasses - Amyiosporme and Gymnospermat. The former inchudes by far the greater part of the Flowering I'lants, and is reporesenterl in I'art I of this work he cightern species. Let it he molerstood, therefore, that its charraters, omitted in further descriptions, apply equally to all the species up) to and including the cighteenth.

\section{ANGIOSIERME.}

Flonering, exogemoms plants in which there is a complete pistil - with stigma and elosed ovaly - eonlanining ovmles which develop into seeds at maturity. This sub-chass comprias many gromps of plants known as Ordere, a fow of which will be taken 11 in the following farges. Consilderimg them in the serpenee commonly accepted by botanists, we will first charaterize the

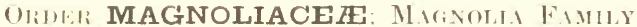

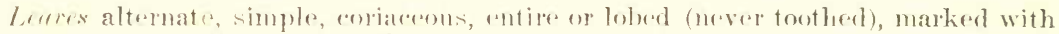

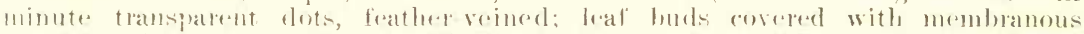
stipules, which son fall away. Flomers singele, latere. polypetalous, polyandrous,

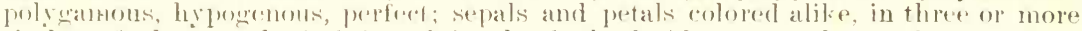

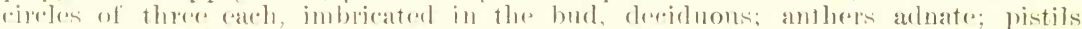
nmmerous, packel together and eorering the elongated receptarele, and forming in Frmit a solt of flesly of dry cone containing one or two secels in eatch carpel, with a

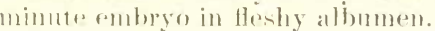

'Trees or shrubs with aromatic and bitter bark.

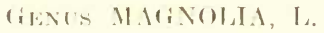

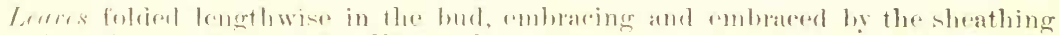

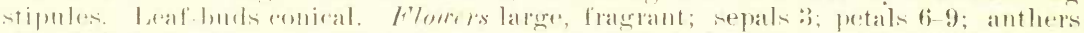

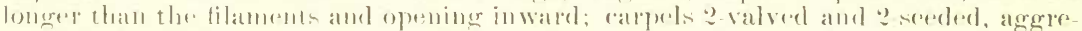

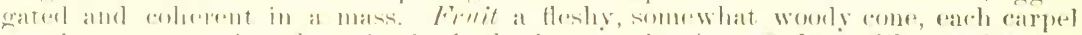

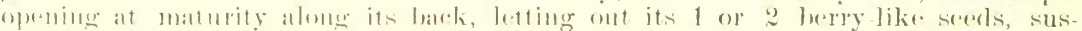

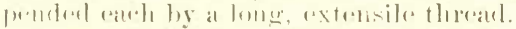

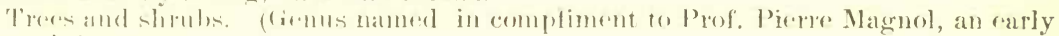
[imench l,otanist.)

\section{MAGNOLIA ACUMINATA, L.}

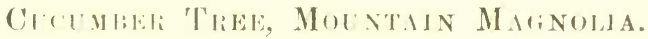

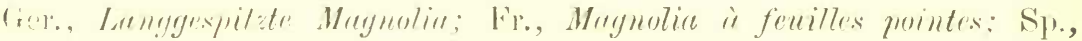
Matguolice artlmimade.

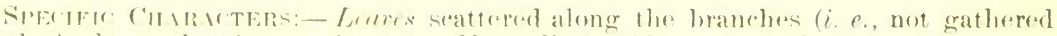
rechusisely at the tips, as in some Magnolias), oblong or oval, armminate, green 
both sides and slightly pubescent beneath; leaf-buds silky. Flowers (May, June) erect, of feeble odor, oblong, bell-shaped with obovate petals about 2 or 3 in. (5 to $8 \mathrm{~cm}$.) in length, glaucous, greenish or bluish tinged with yellow. Fruit a cone 2-3 in. (5-8 cm.) long, usually somewhat curved, giving the appearance of a cucumber; whence the common name-Cucumber Tree.

Fresh bark and leaves, when bruised, of a pleasant, aromatic odor and a bitter, aromatic flavor. (Specific name, acuminata, is Lat. for made pointed, acuminate, and is here applied to the shape of the leaf.)

A large, handsome and symmetrically shaped tree, sometimes reaching the height of $100 \mathrm{ft}$. $(30 \mathrm{~m}$.), with a trunk $4 \mathrm{ft}$. $(1.22 \mathrm{~m}$.) in diameter, straight and cylindrical. It is particularly handsome when in bloom, as then the light green or yellowish blossoms show very prettily against the rich, dark green and rather dense foliage. Later, its curious fruit with dangling bright red seeds, gives the tree from near by, another, yet quite as pretty, aspect.

Habitat. - Western New York to Illinois and southward along the Alleganies to the Gulf States, in rich, deep soil, particularly along slopes where the air is moist from the proximity of water. Reaches its greatest development in the southern part of its range.

Physical Properties. - Wood soft, light, close-grained, durable and compact, yielding a satiny finish. Sap-wood is nearly white and the heart of a yellowish brown or somewhat olive color. The end of the grain in the log, assumes, soon after being cut, a bluish color. Specific Gravity, 0.4090; Percentage of Ash, 0.29; Relative Approximate Fuel Value, 0.4676; Coefficient of Elasticity, 9281\%; Modulus of Rupture, 671; Resistance to Longitudinal Pressure, 415; Resistance to Indentation, 107; Weight of a Cubic Foot in Pounds, 29.23.

UsES. - This wood is extensiveiy worked into furniture, especially of the cheaper grades, crates, packing-boxes, etc. It quite closely resembles the Tulip-wood, with which it is often confounded by careless observers, and, like that wood, is largely used in interior-finishing, as for doors, wainscots, etc. Its compactness makes it especially useful for bowls, troughs, general wooden-ware, pump-logs, cheese-boards, etc., for which it is extensively employed.

Medicinal Properties. - The bark of this species, and also that of other Magnolias, is officinal and possesses gently stimulant, aromatic, tonic and diaphoretic properties. The bark of the root is richest in these properties. It is useful in chronic rheumatism, and capable, if freely given, of arresting the paroxysms of intermittent fever. It has been used advantageously in these complaints and in remittents, especially of a typhoid character. The dose of the recently dried bark in powder is from half a drachm to a drachm (1.95 to $3.9 \mathrm{Gm}$.), frequently repeated. The infusion may also be used, but is less efficient. Diluted alcohol extracts all the virtnes of the medicine; and a tincture, made by 
macerating the fresh bark or fruit in brandy, is a popular remedy in chronic rheumatisnı.*

NotE. - A very thin longitudinal section of this timber, looked through in the dark toward a lighted lamp, shows an interesting and pretty phenomenon. As it is held with the grain horizontal, there is seen to the right and left of the light - or the lighted point directly in range with the light - a display of the prismatic colors, which is quite brilliant and beantiful. They seem like miniature sundogs, and there are two or three of them on each side of the light, those nearest being brightest.

A microscopic examination reveals the cause of this interesting appearance. The wood is found to be copiously supplied with spiral ducts, $i$. e., ducts whose walls are marked with a spiral thickening (See $\S 11$, p. 2). These spirals are so small that their coils would number several thousand to the inch. They can be distinctly traced by varying the focus of the instrument; but, at a certain focus, where only one side of the spiral can be seen, they seem like rows of parallel crystals or prisms, and it is by these that the light is refracted, causing the display of colors quite as the crystals of frost in the air in winter cause the colors in the sundogs.

\section{GeNUS LIRIODENDRON, L.}

Leaves folded crosswise in the bud, each infolding all that is interior to it, and is itself infolded by its pair of stipules and the next lower leaf, and so on; buds flat, the large, sheathing, oval stipules caducous. Flowers showy, with 3 reflected cadu. cous sepals, and 6 erect petals in two rows, making a bell-shaped corolla; anthers linear, opening outward; carpels flat, scale-like, long and narrow, imbricating and colhering together in an elongated dry cone, separating at maturity and falling away whole as samaræ, somewhat lanceolate in shape and each bearing 1-2 seeds in its base, indehiscent.

Trees of fine aspect. (Name from the Gk. $\lambda \varepsilon \imath \rho \imath o \nu, l i l y$, and $\delta \dot{\varepsilon} v \delta \rho o \nu$, tree.)

\section{LIRIODENDRON TULIPIFERA, L.}

Tulip Tree, White-Wood, White or Yellow "Poplar," CanoeWOOD.

$$
\text { Ger., Tulpenbaum; Fr., Tulipier; Sp., Tulipifero. }
$$

Specific Characters :- Leaves dark green, very smooth and shining, truncate, with two spreading lobes separated by a broad, shallow sinus at the apex, and with two lateral lobes near the base, $3-5$ in. $(8-13 \mathrm{~cm}$.) in length and of about the same width, long petioles. Flowers (May, June) solitary, erect, more bell-shaped than the common garden tulip, greenish yellow marked with orange. Fruit (September) a greenish cone $2-3$ inch. $(5-8 \mathrm{~cm}$.) in length, the scales of which - in reality so many sameræ - persisting long after the leaves have fallen, and then more or less spreading and bleached nearly white, give the tree in winter a very characteristic appearance.

(Tulipifera from Persian toulyban, a turban - whence from resemblance in the tlower the Eng. "tulip" - and Lat. fero, I bear.) 
One of our grandest trees, sometimes $150 \mathrm{ft} .(46 \mathrm{~m}$.$) in height and$ with a trunk $10 \mathrm{ft}$. $(3 \mathrm{~m}$.) in diameter at the base, columnar, and of great length. Branches regularly disposed. The bruised bark or leaves, when fresh, possess a rather pleasant aromatic odor and bitter, pungent flavor.

Habitat. - Southern New England, New York and Ontario to Michigan and thence southward nearly to the Gulf coast, reaching its maximum development between the Alleganies and the Mississippi.

Physical Properties. - Wood light, rather strong, with close, straight grain, compact, easily worked and yielding a satiny finish. Sapwood nearly white; heart-wood of a light lemon yellow color, or sometimes of a brownish tint - whence its two seemingly contradictory names, White and Yellow Poplar, the former referring to the sapwood and the latter to the heart. The name "Poplar," though, is wrongly applied to this species, as it is very different from and much more valuable than the true Poplar. Specific Gravity, 0.4230; Percentage of Ash, 0.23; Relative Approximate Fuel Value, 0.4220; Coefficient of Elasticity, 9266\%; Modulus of Rupture, 65\%; Resistance to Longitudinal Pressure, 372; Resistance to Indentation, 82; Weight of a Cubic Foot in Pounds, 26.36.

UsEs. - This timber, being comparatively tough and easily worked, is extensively substituted in localities where abundant for the white pine in interior-finishing - doors, panels, wainscoting, - and is sometimes used for boat-building, shingles, etc. It very much resembles cucumberwood, and is largely used for the same purposes as that timber - for pump-logs, bowls and wooden-ware in general. It is said to make excellent charcoal. Paper has been made from the bark.* The name canoewood was given to this timber from the fact that the Indians found it one of the very best for use in making their "dug-out" canoes, and they are said to have made them large enough sometimes to carry twenty or thirty persons in a single canoe.

Medicinal Properties. - The bark, especially of the roots, possesses medical properties which are "stimulant, tonic and diaphoretic. It has been used as a substitute for Peruvian bark in intermittent fevers, and has proved serviceable in chronic rheumatism, dyspepsia, and other complaints in which a gentle stimulant and tonic impression is desirable. The dose of the bark in powder is from half a drachm to two drachms. The infusion and decoction are also used, but are less efficient. They may be prepared in the proportion of an ounce of the bark to a pint of water and given in the quantity of one or two fluid ounces. The dose of the saturated tincture is a fluid drachm." $\dagger$

* Elements of Forestry. By Franklin B. Hough, p. 250.

$+U$. S. Dispensatory, 15 th ed., p. 1687 . 
The above is what we learn from officinal source, but it might not be out of place to further mention that in Micheaux "Sylva" (vol. II., pp. 41 and 42 ) wo find that, "combined with laudanum (which makes it more easily borne in the stomach), it has frequently dissipated alarming symptoms of pulmonary consumption. It has also been successfully used in a case of catarrh complicated with dyspepsia, in hysterical affections (in the latter case combined with a small quantity of laudanum), in cholera infantum, and as a remedy for worms. In a persistent case of remittent fever it was found more efficacious than Peruvian bark."

\section{ORDER TILIACEA: LiNDEN FAMILY.}

Leaves simple, stipulate, alternate, dentate. Flowers polypetalous, or rarely apetalous, axillary, hypogenous, usually perfect and polyadelphous; sepals 4-5, deciduous, valvate in the bud; petals 4-5 imbricated in the bud; stamens numerous and with versatile anthers; ovary of $2-10$ united carpels; styles united and stigmas as many as the carpels. Fruit dry or succulent, many celled, or, by abortion, 1-celled, each cell bearing from one to several seeds.

Represented by trees, rarely shrubs or herbs.

\section{Genus TILIA, L.}

Leaves more or less heart-shaped and oblique, serrate; stipules deciduous. F'lovers cream color, in small cymes, hanging on an axillary peduncle, which is adnate to the vein of a large, leaf-like bract; sepals 5, united, colored; petals 5, spatulate-oblong; stamens numerous, the filaments cohering in clusters, and with each cluster in the American species is a spatulate, petal-like scale, placed opposite each of the real petals; ovary superior, 5 -celled with 2 ovules in each cell; style single, stigma 5-toothed. Fruit a globose and rather woody nut, 1-celled by abortion and 1-2-seeded. In the dissemination of these, the leaf-like bract, described above, acts as a parachute.

Trees. ("Tilia" is the ancient Latiu name of the Linden.)

\section{TILIA AMERICANA, L.}

\section{Basswood, American Linden or Lin, Lime-'Tree, Bee-Tree.}

\section{Ger., Amerikanische Linde; Fr., Tilleul d'Amerique; Sp., Tilio Americano.}

Specific Characters:- Leaves large, 3-5 in. (8-13 cm.) or more in length and about as broad, more or less heart-shaped and unequal at the base, serrate, pointed, green on both sides and glabrous or nearly so. Flowers cream-color, richly fragrant and honey-bearing, each flower having interior to its petals and opposite them, five petallike bodies, at the bases of which are the stamens arranged in clusters or tufts.

A large and important forest tree in the Northern and Middle States, growing in loose, rich soil, and often attaining the dimensions of $80 \mathrm{ft}$. $(24 \mathrm{~m}$.$) or more in height and 4 \mathrm{ft} .(1.22 \mathrm{~m}$.) in thickness of trunk near the base. When growing in open fields, the top develops symmetrically and to a large size. 
Habitat. - North-eastern United States and, less abundantly, Canada, westward to Nebraska and Kansas, and southward along the Alleganies to the Gulf States.

Physical Propertics. - Wood light, soft, quite tough, close-grained, compact and easily worked. Sap-wood, when properly seasoned, is very light colored, nearly white, but as more often seen is tinted with a brown or yellowish color; heart, light brown. Specific Gravity, 0.4525; Percentage of Ash, 0.55; Relative Approximate Fuel Value, 0.4500; Coefficient of Elasticity, 84010; Modulus of Rupture, 589; Resistance to Longitudinal Pressure, 348; Resistance to Indentation, 63; Weight of a Cubic Foot in Pounds, 28.20.

USES. - This timber is useful for many purposes, taking the place of pine in some localities, and very largely the place of the tulip and cucumber wood north of the range of those timbers. It is extensively used for furniture, especially drawer-backs and sides, sometimes for interiorfinishing, for wooden-ware, etc., and to some extent for paper pulp and charcoal. A use for which it is particularly adapted on account of its toughness is the manufacture of panels, carriage and cutter boxes, dashes, etc. For getting out lumber for this latter use, we have recently seen a new and very ingeniously devised machine, used at first at least with this kind of timber exclnsively. It is for sawing around the log, thus making a board as long as the log and perhaps a hundred feet broad, when the $\log$ is very large - a curious looking board as it stands on end (of the grain), coiled up like a huge roll of carpeting.

The inner bark of this wood, known as bast,- whence the name Bastwood or Basswood,- is very fibrous and used, after macerating, in the manufacture of matting and an inferior cordage.

A by no means unimportant point of value in connection with this tree is the most excellent honey which its flowers yield in abundance, and so active are the myriads of bees and other insects in gathering this during the flowering season that the din of their humming may be heard some yards from the tree.

Medicinal Properties. - None are officinally recognized in this country. In Europe, however, Aqua Tilice, which is an infusion of the flowers, buds and leaves of the various species of Tilia, is said to possess anti-spasmodic and cephalic properties. It is used as a domestic remedy in cases of indigestion, nervousness, etc. (Nat. Dispensatory, 2d ed., 1429.)*

\section{ORDER SIMARUBACEAE.}

Leaves generally compound and alternate, inodorous and not bearing pellucid dots. Flower's polypetalous, regular, 3-5-numerous, hypogenous, perfect or polygamous;

*U. S. Census, 1880, vol. IX, p. 27. 
stamens distinct and usually as many or twice as many as the sepals; pistils $2-5$, separate or combined into a compound ovary of as many cells, sessile or raised on a prolongation of the receptacle; styles mostly cohering. Fruit usually capsular, 1-2 seeds in each carpel.

Shrubs and trees.

Genus AIlanthus, Desr.

Leaves pinnate. F'locoers small and greenish in panicles, polygamous; sepals 5 , more or less united at the base; petals 5; stamens in the perfect flowers $2-3$, in the monœcious flowers 10; ovaries $2-5$, styles lateral. Fruit 1-celled, 1 -seeded, linearoblong, thin, veiny samaræ.

Trees and shrubs.

(Ailanthus is formed from the Molucca name Ailanto or Aylanto.)

\section{AILANTHUS GLANDULOSUS, Desf.}

Ailanthus, Tree-of-Heaven.

Ger., Drüsiger Götterbaum; Fr., Ailante glanduleux; Sp., Barniz falso de Japan.

Specific Characters:- Leaves glabrous, sometimes $4 \mathrm{ft}$. (1.22 m.) long, pinnately compound with 10-20 pairs of leaflets and an odd terminal one; leaflets pointed, oblonglanceolate or ovate, with one or two glandular teeth near the base, short-petiolate excepting the terminal one which is long-petiolate. Flovoers (May, June) in terminal panicles, polygamous, small, greenish and of disagreeable odor.

(The specific name, glandulosus, is a Latin word meaning gland-bearing.)

A large tree of rapid growth, luxuriant foliage and rather smooth bark.

HaвITAT. - An introduced tree of hardy nature. It grows well with us in nearly all localities, and in places seems thoroughly naturalized. It is a native of China and Japan.

Physical Properties. - Wood not very hard, of medium weight and rather open grain; light brownish yellow; sap-wood lighter than the heart, and the line of transition from sap to heart is marked by an orangecolored band.

USES. - The timber is very little used in this country, but in Europe is used in the manufacture of wooden-ware and for charcoal. In this country the Ailanthus is principally useful as a shade tree, and is especially suited to planting in city parks and along streets, owing to its very rapid growth and handsome ample foliage. However, it has one bad trait, which in the minds of those living near it often countervails all that may be said in its favor; - the odor which its blossoms emit is very disagreeable and sickening. Considering that, the name Tree-of-Heaven seems to be very wrongly applied. All we can say is that it is a translation of the Molucca name, Ailanto, which is said to be given to it on account of its lofty growth. Its growth may seem lofty enough in the Moluccas to justify such an appellation, but it could hardly be compared with many of our native American trees. In China and some parts of Europe the leaves afford food for a species of silk-worm, which produces an excellent quality of silk. 
Medicinal Properties. - The bark, which possesses a pungent bitter taste, has been found to possess "active anthelmintic properties. In a powdered state, in dose from 7 or 8 to 30 grains $(0.46$ to $1.95 \mathrm{Gm}$.), it has been given in several cases of tape-worm in the human subject, and has proved remarkably successful in causing its expulsion, at the same time having a not very violent cathartic action. In China the bark is very popular as a remedy for dysenteric and other bowel complaints." *

\section{ORder ANACARDIACEß, Cheshew FAMILY.}

Leaves alternate, simple or compound, without pellucid dots; stipules none. Flowers polypetalous, small, often polygamous, regular and furnished with bracts; sepals 3-5, united at the base, persistent; petals 5 (or sometimes wanting), imbricated in the bud; stamens 5, alternate with the petals, perigynous; ovary free, 1-celled and 1-ovuled; styles or stigmas 3. Fruit a berry or drupe, the seed containing no albumen.

Trees or shrubs with a milky resinous or gummy acrid juice, which as well as the exhalations are often poisonous.

\section{GENUs RHUS, L.}

Leaves mostly compound. Flowers greenish or yellowish, often imperfect by abortion; styles 3; stigmas capitate. Fruit a small, indehiscent, 1-seeded, dry drupe.

(The name Rhus is the old Latin and Greek for the Sumac.)

\section{RHUS TYPHINA, L.}

\section{Sumach, Stag-horn Sumach, Virginian Sumach.}

\section{Ger., Hirschkolben Sumach; Fr., Sumac; Sp., Zumaque.}

Spectfic Characters. - Leaves odd-pinnate with 11-31 oblong-lanceolate pointed and serrate leaflets more or less pubescent beneath. Branches, leaf-stalks etc. densely velvety hairy. Flowers (June) polygamous in terminal thyrses. Fruit globular, clothed with very acid crimson hairs and containing a smooth stone. Not poisonous to the touch as are some representatives of the genus.

A small tree, with thick straggling branches, very rarely attaining the dimensions of $20 \mathrm{ft} .(6 \mathrm{~m}$.) in height and $10 \mathrm{in} .(0.25 \mathrm{~m}$.) in diameter of trunk at base; often hardly more than a shrub. The bark when bruised yields an abundant milky and sticky juice. The leaves put on their bright autumnal tints early, and the compact bunches of downy red fruit on the tips of the branches give the tree a striking and characteristic appearance after the leaves have fallen. The name "Stag-horn" is given to this species from the resemblance we see in the soft velvety coating of the twigs, to that of the stags antlers when growing and "in the velvet." The branching of the tree likewise is quite suggestive of the branching of a pair of antlers. 
HABITAT. - Canala and north-eastern United States, westward to Minnesota and reaching its southern-most limit along the Alleganies, growing in stony sandy soil, particularly on open hill-sides, where we often find it in extensive thickets.

P'misical Properties. - Wood light, soft, brittle, rather closegrainen, of a markedly greenish and yellowish color and somewhat aromatic. The sap-wool which occupies scarcely one annual ring is nearly white next the bark, and of a handsome gold and orange color farther in. When freshly worked the wood is very beantiful, but in time loses in prart the brightness of its colors. Specific Gravity, 0.435\%; Percentuge of Ash, 0.50; Relative Approximate Fuel Value, 0.4335; Weight of a Cubic Foot in. Ponmds, 2\%.15.

USEs. - Timber camnot be oltained in large enough pieces to be of great utility. It is oecasionally used as choice pieces for inlaying cabinetwork, where it finishes nicely and hats a beautiful effect. 'The wool is said sometimes to be nserd in dyeing. The bark and leaves as well as the frut are usen for the sime purpose.

Mencinal Propentres.- None are officially recognized of this species, althomgh some are aseribed to the closely allied Smooth Sumach (li. glabra). Of that the berries are astringent and refrigerant, a decoction or dihnten fluid extract of which - especially in rombination with the chlorate of potassium - affords an effective and pleasant gargle in inflammation and ulceration of the throat.*

The root hat been fomm efficacious in fevers.t

\section{ORDER SAPINDACEAE: SOAPBEIRY FAMILY.}

luaves simple or compound. Florers polypetalons, often irregular and mostly srmmetrical: sepals and petals each 4-5, imbricated in the bud, the petals inserted with the 5-10 stamens on a perigraons or hypogrenoms disk; ovary ?-3-erelled and lobed, usnally 1-2 orules in each cell, embryo mostly couvoluted; no albumen. Fruit a mombranous, inflated pod, a leathery thick subspherical pod with nut-like seeds, or at winged samara.

\section{MEXTS ASCULTS, I}

Leares opposite, digitately compound, destitute of stipules; leaflets serrate and straight veined. Florepe panioulate, terminal, mosmmetrical, irregular, often polygamous; perliecls jointed: ablyx tubular, 5-tonthed, often rather giblons at the

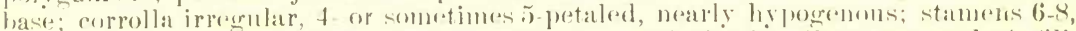

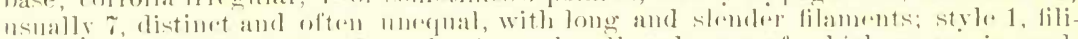

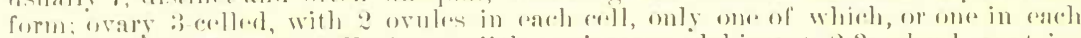

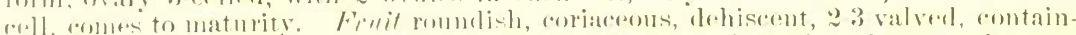
ing $1: 3$ larere. smosth, leathely and shininge sereds, earld with a large, pale sear; rotylefous thick, bulky and inseparable, rich in starch, but of bittre tastre, momaing

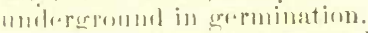

(A sculus is a fatin name, but in ancirnt times applied to a kind of oak.)

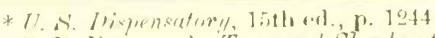

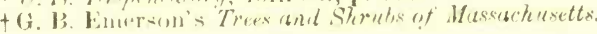




\section{6. ÆSCULUS HIPPOCASTANUM, L.}

\section{Horse Chestnut.}

\section{Ger., Roszkastanie; Fr., Marronier d' Inde; Sp., Castaño de caballo.}

SPECIFIC Characters:- Leaves digitately compound, with seven obovate or somewhat wedge-shaped, serrate leaflets. Flowers (May, June) in very showy pyramidal racemes; petals five, spreading, white or with a pink flush, spotted with purple and yellow; stamens declined. There are double-flowered, variegated and other varieties with more or less lobed or cut-leaves.

(Hippocastanum is from Gk. i $i \pi \sigma^{\circ}$, horse, and $x a^{\prime} \sigma \tau \alpha \nu o v$, chestnut. The name is applied to the tree from the fact that in some parts of Europe its fruit is employed in veterinary medicine.)

A very common and handsome shade-tree, usually of medium size, though sometimes attaining the dimensions of $80 \mathrm{ft}$. ( $24 \mathrm{~m}$.) in height, and $4 \mathrm{ft}$. $(1.22 \mathrm{~m}$.) in thickness of trunk at base. While in blossom, this is one of our most showy trees, with its numerous pyramids of handsome flowers contrasting boldly with the dark green and copious foliage.

Habitat. - As this is an introduced tree, no particular habitat in this country could be given. It grows well and quite rapidly wherever planted in the United States, especially in the Middle and Southern States. The climate here in Northern New York seems a little too rigorous for it. Its native country is slipposed to be Asia, whence it has been extensively introduced into Europe and thence into the United States, where it is now abundant in parks and along streets as an ornamental shade tree.

Physical Properties. - Wood light, soft and very elose-grained, whitish, slightly tinted with yellow.

UsES. - In this country this timber could hardly be said to be put to any particular use at present as it is not in the market, and, with our numerous native timbers, we scarcely feei the need of it. In Europe it is of value in the hands of carvers and turners, which we would naturally infer from its soft, fine and close-grained nature. The bark, which is bitter and astringent, has been used for tanning and dyeing, and an extract of the wood is said to be used in dying silk black. The kernels of the nuts possess a saponaceous substance in such abundance that, when powdered, they may be used for washing. The abundance of starch which they contain is pleasant to the taste and nutritive, after counteracting the bitter principle by means of an alkaline solution. They also make very good food for cattle, sheep, swine and horses.

Meijcinal Properties. - "The bark has been used as a substitute for cinchona bark as an antiperiodic for use in intermittent ferers etc. Dose half an ounce in twenty-four hours given in the form of a decoc- 
tion. A fixed oil from the kernels, extracted by means of ether, has been used in France as a topical remedy in rheumatism." *

\title{
Genus ACER, TOURN.
}

Leaves opposite, simple, palmately-veined, 5- or occasionally 3-lobed; stipules none. Flovers small, in axillary racemes or corymbs, regular, polygamo-dicecious, usually unsymmetrical; pedicels not jointed; sepals 5 (or 4-9), more or less united, colored; petals sometimes wanting, but, when present, 5 (or 4-9), equal and furnished with short claws; stamens, commonly 8; ovary 2-lobed, formed of 2 united carpels, each bearing 2 ovules, only one of which commonly attains maturity; styles 2 , long and slender, united only below and stigmatic down the inside. Fruit a double samara, finally separating when mature and ready to fall, the wings strengthened by a rib along one margin; cotyledons, long and thin.

(Ancient Latin name of the Maple.)

\section{ACER SACCHARINUM, WANG.}

\section{Sugar Maple, Hard Maple, Rock Maple, Sugar-Tree.}

\author{
Ger., Zuker Ahorn; Fr., Erable á sucre; Sp., Acer de azucar.
}

SPECIFIC Characters:- Leaves more or less cordate at the base; 3-5-lobed with rounded sinuses and pointed remotely sinnate-toothed lobes; rather pale and glaucous, or slightly downy on the veins beneath. Flowers in handsome pendulous umbellate-corymbs, with long thread-like hairy pedicels, greenish-yellow and appearing with the leaves; calyx hairy at the apex; petals none. Wings of the fruit only slightly diverging. A variety known as var. nigrum, the Black Maple (considered by some as a distinct species, $A$. nigrum), is characterized by having leaves with closed sinuses, divaricate lobes and rather paler, usually slightly pubescent under surface; wings of the fruit more diverging.

(Saccharinum is Latin for "sugar.")

This tree when growing in the forest sometimes attains a height of $100 \mathrm{ft} .(30 \mathrm{~m}$.$) or more, with a trunk perhaps 50 \mathrm{ft}$. $(15 \mathrm{~m}$.) long and 4 ft. $(1.22 \mathrm{~m}$.$) in diameter at the base. In such situations the tops are$ usually unsymmetrical and the trunks often more or less crooked and leaning. Growing in the open it has a very different appearance. The tops are there very large and developed with great symmetry and density of foliage, more or less ovoid in outline and with short, thick and straight trunks.

HABIтAт. - Canada westward as far as the shores of Lake Superior, and reaching its northern-most limit along the coast. North-eastern United States, westward to the Mississippi, and southward along the mountains to western North Carolina, in calcareous and loamy soil, often being the principal if not the exclusive timber of tracts of forest. In the Adirondack forests we have noticed this tree particularly, and there find it in its greatest vigor of development.

Physical Properties. - Wood very hard - hence the name "Hard Maple" - heary, close-grained, compact and strong. 'The most perfectly 
seasoned sap-wood is of a light, slightly yellowish color; the heart-wood brownish of various tints. Specific Gravity, 0.6912; Percentage of Ash, 0.54; Relative Approximate Fuel Value, 0.68\%5; Coefficient of Elasticity, 146108; Modulus of Rupture, 11499; Resistance to Longitudinal Pressure, 619; Resistance to Indentation, 25\%; Weight of a Cubic Foot in Pounds, 43.08 .

UsEs. - This is one of the most useful trees of Canada, New England and the Middle States. Its timber is used in the manufacture of furniture, for interior finishing, flooring, ship-building - especially for keels etc., where great durability and strength are required - shoe-lasts, pegs, wooden-ware etc. Wooden-bowls of this timber are considered the best in market. It makes excellent fuel, and its ashes are very rich in alkali, yielding much of the potash and perlash of commerce.

Maple Sugar - in the tastes of many the most delicious of sweets - is almost exclusively the product of this tree, the very small quantity which is made from other Maples, being in proportion very insignificant. It is made by evaporing the sap to a proper consistency, and then pouring into monlds, where it hardens in eake form, or it is stirred while cooling so as to make a granulated sugar. The sap is procured by tapping the trees, usually with a $\frac{1}{2}$ to $\frac{3}{4}$ in. auger, in early spring, some weeks before the buds begin to swell, and into the hole a spout is driven to carry the sap away from the tree. It drops from the spout in good weather, at the rate of from $30-100$ or more drops per minute into a bucket placed to catch it. It is then clear and colorless, seeming quite like water, and of a slightly sweetish flavor. About 3 or 4 gallons are usually required to make a pound of sugar, the sweetness of the sap varying more or less with different trees. In quality, too, if not also in sweetness, it is variable in the same tree, being better early in the season than later. 'Two or three pounds or less of sugar per tree is the ordinary average yield when the trees are standing close to each other, as in groves, but where isolated or thinly scattered, so that the tops are extensively developed, the yield is much larger. In the small sugar "bush" or "orchard" (as a Maple grove used for sugar-making is called) of about seventy-five trees, which we have, we get an average yield of five or six pounds per tree in good seasons; but it must be borne in mind that the trees are very large and seattered, having fully developed tops. They are tapped with one spont;-it is customary with some to use two or more. A few select trees would probably yield eight or ten pounds each in a season.

Tapping when prudently done does not seriously impair the health of the tree. Naturally it kills the fiber for a little way, directly above and below the place of tapping, but in two or three years new wood forms 
over the hole, and in a few years all traces are obliterated from external view. My father observes* that "upon some farms in Vermont and northern New York, more profit is realized from a maple wood-land than could possibly be gained upon an equal area by any agricultural crop."

Note.- There are peculiar freaks sometimes in the growth of timber, and how and why these occur are interesting problems in the minds of vegetable physiologists, thus far unsolved as they probably must always remain. Two or three forms of these freaks occur especially - thongh we could not say exclusively - in the timber now before us, and so interesting and important are they from a commercial point of view, and so beautiful, that we have decided to exhibit them in the accompanying sections, and this text would certainly be very incomplete without mention of so important timber products.

The forms to which we refer are commonly known as "figures," and certain ones, such as the "Blister," "Birds-eye" or "Pin" and "Curley" figures much more frequently occur for some unknown reason in the Maples than any other timber with which we are acquainted. The first two might almost be said to be peculiar to the Hard Maple, and we have exhibited them along with the plain timber of that species - as their proper place. The last mentioned figure, Curley, is found in the Hard Maple, but also and perhaps even more commonly in the larger Soft Maples, and hence has been left to be shown in connection with them in a succeeding part of this work. The three figures are often found in the Hard Maple, more or less mixed, but for our sections, standing as specimens of the various forms, we have endeavored to select timbers as exclusively representing those particular forms as conveniently possible.

In the untonched tree, as it occurs in the forest, it takes an experienced eye to detect a figure, so slight are the evidences before the timber is exposed, To such an eye a slight pit or elevation in the bark, or a peculiar form of trunk or top, means a great deal. With such a man of experience (John Brown, Esq., of Lowville, N. Y.), who gathers this timber quite extensively for the market, it has been our pleasure to visit forests occasionally, in quest of these figured timbers. From him we have learned to read in the bark of the trees signs which we never knew if we ever even saw before. It is principally from that schooling that we are able to note the following facts concerning the figured Maples as they appear in the tree.

The Blister Maple, as the Blister figure of the Hard Maple is usually called, is so named from the resemblance which its polished sur-

* Elements of Forestry, p. 236. 
face gives to a surface covercd with blisters. Some call it "Landscape" Maple from the suggestions seen in it of a mountainons landscape, as imagined from some great height. The name is certainly very applicable to some specimens, as the fancied representation of mountain ranges, isolated peaks and deep valleys is very complete. A purcly blister figure is the rarest of the three varieties above mentioned. One might have to examine many hundreds of trees before finding one nicely blistered. The one used for the accompanying sections was the best one found in the examination of actually thonsands of trees - such is the rarity of a purely blister figure. Trees are more often found where it is combined with the bird's-eye and curly figures.

The trunk of a Blister Maple tree usually seems massive for the size of the top. Upon striking off a piece of the bark, the surface of the wood is found to be covered with wart-like eminences quite like the surface of a rough, warty squash. The inside surface of the bark is pitced to correspond with the prominences of the wood. The figure is best near the bark, growing poorer as we approach the heart; and, to show it to best advantage, the $\log$ is cut into veneering by means of a huge lathe, which turns off a great shaving the length of the log, and round and round it until the heart is reached, or as long as the figure lasts. This gives the tangential view of the grain, as shown in the sections. The transverse and radial views are rarely if ever seen in the commercial veneering, but are interesting here as showing, from all sides so to speak, the peculiar formation of the figure.

The Bird's-eye Maple, or Bird's-eye Figure of the Hard Maple, is so called from the appearance of birds' eyes, which, in a certain aspect, its polished surface presents. It is more common than the distinctly blister figure, and much that we see has the latter combined with it. It is rarely if ever found, so far as our experience goes, in the SoftMaples. In the tree a bird's-eye figure may be detected by characteristic pits in the bark, but they are usually inconspicuous. The top of the tree often seems small and rather scraggy for the size of the trunk. On removal of the bark the wood is found to be deeply pitted - instead of warty, as in the Blister Maple - and in the bark are projections, or little nibs, corresponding with the pits in the wood. On examination of a transverse section of the wood; we find that these pits are shown in the grain nearly to the center of the tree, and present the appearance of so many pins pointing in toward the center from the bark. Hence the name, "Pin" Maple, which is sometimes applied to this form. The "pins," when cut across - $i$. e., in a section tangential to the grain as seen in most of the veneering, present the "eyes," as they are called from something of a resemblance to birds' eyes. 


\section{Order ARALIACEAE: Ginseng Fammiy.}

Leaves mostly compound and alternate, petioles dilated and sometimes thickened at the base; stipules none. Flowers small, polypetalous (or rarely apetalous), often polygamous, mostly umbellate and the umbels solitary, racemed or panicled; calyx adherent to the ovary; its small limb being entire or toothed; petals 5-10 valvate (not inflected) in the bud; stamens of same number as petals and alternate with them; styles and cells of the ovary usually more than two (3-5). Fruit baccate or drupaceous, 3-5-celled, one seed in each cell; albumen fleshy.

Represented by trees, shrubs and herbs.

Genus ARALIA, Tourn.

Leaves compound or decompound. Flowers white or greenish; calyx with teeth nearly or quite obsolete; petals 5 , spreading, oblong or obovate, epigynous, deciduous; stamens epigynous; styles mostly distinct and slender, in sterile flowers short and united. Fruit as described for the order.

(Derivation of name obscure.)

\section{ARALIA SPINOSA, L.}

\section{Hercules'-Club, Angelica-Tree, Toothache-Tree.}

Ger., Dornige Bergangelike; Fr., Aralia espineuse; Sp., Aralia espinosa.

Specific Characters:- Leaves very large, pinnately decompound, with ovate, pointed, serrate, sessile leaflets, pale glaucous beneath. Flowers (July, August,) polygamous or perfect, in numerous umbels, and these forming large, compound panicles.

(Spinosa, a Latin word meaning thorny, spiny.)

A small tree with trunk branches and petioles furnished with spines. Often hardly more than a shrub, but in the south, and occasionally in favorable. situations in the north attaining the dimensions of 20 to 30 ft. $(6$ to $9 \mathrm{~m}$.) or more in height, and $12 \mathrm{in.}(30 \mathrm{~cm}$.$) in diameter of$ trunk at base. Bark of an aromatic, bitterish and somewhat acrid taste. The tree from which the sections of this species were cut measured 27 ft. $(8.22 \mathrm{~m}$.$) in height and 30 \mathrm{in} .(76.2 \mathrm{~cm}$.) in girth of trunk at base. It grew on the grounds of Dr. Parker, of Ithaca, N. Y., and must be considered a very large tree of its kind for so northern a climate.

Haвitat. - Found native from Pennsylvania to Kentucky and sonthward, along river banks and in damp woods. Is grown in cultivation outside of that range.

Physical Properties. - Wood light and brittle, seeming, when fresh, of an almost herbaceous or succulent nature, brownish-yellow of various tints.

UsES. - An ornamental shade-tree, particularly interesting from its curious, very large, decompound leaves. The timber is of little or no value for manufacturing purposes.

Medicinat Properties of this species are "stimulant, diaphoretic, and an infusion of the recent bark is said to be emetic and cathartic. 
It is used as a remedy in chronic rheumatism and cutaneous eruptions, and for relieving rheumatic pains a vinous or spirituous infusion of the berries is said to be remarkable. A similar tincture is employed with advantage sometimes in cases of violent colic, and the pungency of this tincture has been found useful in relieving toothache; hence the name, in some localities, Toothache-Tree." *

\section{ORDER CORNACEAE: DOGWOOD FAMILY.}

Leaves opposite (except in one species), simple, mostly entire. Flowers in cymes, often involucrate, polypetalous (exceptionally apetalous), 4-numerous; calyx-tube adherent to the ovary, its limb minute; petals valvate in the bud, oblong, sessile, and, with the stamens, borne on an epigynous disk in the perfect flowers; ovary 1-celled, bearing a single suspended ovule; style single, somewhat club-shaped. Fruit a 1-2-seeded baccate drupe, bearing the persistent limb of the calyx.

Trees, shrubs or rarely herbs, with bitter, tonic bark.

\section{GENUS NYSSA, L.}

Leaves mostly entire, but sometimes angulate-toothed, and mostly at the ends of the branchlets. Flowers greenish and appearing with the leaves, diœcious or polygamous, clustered or rarely solitary on axillary peduncles. Staminate flowers more numerous, and in these the calyx-tube is small, limb truncate or 5-parted; petals usually 5, small, oblong and soon deciduous or wanting; stamens 5.12, commonly 10 , inserted outside of a convex glandular disk, filaments slender; anthers short; ovary none. Pistillate flowers much larger than the staminate; calyx-tube oblong, adherent to the ovary, limb a mere rim as with staminate flowers; petals $2-5$, as in staminate flowers, or wanting; ovary 1-celled, style large, revolute, stigmatic down one side. Fruit an ovoid or oblong, one-seeded drupe, with a striated stone.

\section{NYSSA MULTIFLORA, WANG.}

\section{Tupelo, Pepperidge, Black Yellow or Sour Gum, Gum-Tref. Ger., Sauer Gummibaum; Fr., Gommier multiflore; Sp., Tupelo.}

Specific Characters:- Leaves $2-5$ in. $(5-13 \mathrm{~cm}$.) long, oval or obovate, usually acuminate, but sometimes obtuse, at each end, entire and of firm texture, glabrous or villous-pubescent when young, at least on the petiole midrib and margins, shining above when old, changing early in autumn to a bright crimson. Fertile flowers (April, June) 2-8, clustered at the end of a slender peduncle; style revolute. Fruit (September) an ovoid, bluish-black drupe (from two to four only of a flower cluster, usually maturing), about 6 lines in length, with a scanty flesh of acid taste and a large stone longitudinally striated.

(The specific name, multiflora, is the Latin for " many-flowered.")

A tree of very variable aspect and medium-size, though it is said to sometimes attain, in southern United States, the height of $120 \mathrm{ft}$. $(36.5 \mathrm{~m}$.$) and 4 \mathrm{ft} .(1.22 \mathrm{~m}$.) in thickness of trunk at base. It is usually copiously supplied with branches, which grow out horizontally, giving the tree a handsome and peculiar appearance. 
HabItaT. - Eastern United States, though sparingly in the north and there not attaining its full size, growing in rather damp soil, and in the south in swamps and marshes.

Physical Properties. - Wood rather heavy, soft, very strong and tough owing to the interlacing of its fibers, which makes it very unwedgable; sap-wood light yellow with a slightly brownish tint; heart-wood light brown. Specific Gravity, 0.6356; Percentage of Ash, 0.52; Relative Approximate Fuel Value, 0.6323; Coefficient of Elasticity, 81932; Modulus of Rupture, 830; Resistance to Longitudinal Pressure, 468; Resistance to Indentalion, 196; Weight of a Cubic Foot in Pounds, 39.61.

UsES.-Owing to the great difficulty in splitting and working this timber, it is useful for but comparatively few purposes, and those such as require that quality. It is used in the manufacture of hubs for wagon wheels, rollers, ox-yokes, hatters' blocks, sometimes for bowls and other similar wooden-ware, etc. It is useful, too, for pump-logs, aqueduct pipes, etc., being so tough that it requires no hoops. It is said to be extensively used for that purpose at the Syracuse salt works.

Medicinal Properties. - None are ascribed to this species.

\section{Order OLEACER: OLIVE FAMily.}

Leaves opposite and single or pinnately compound. Flowers monopetalous (rarely apetalous or polypetalous); calyx 4-cleft, toothed or entire, or sometimes wanting; corolla regular, 4-cleft (or sometimes 4-petalous, or even wanting altogether); stamens only 2 (or rarely 4 ); ovary 2 -celled with usually 2 suspended ovules in each cell. Fruit fleshy or capsular, containing 4 (or fewer) seeds.

Represented by trees and shrubs.

\section{GENUS FRAXINUS, TOURN.}

Leaves petioled, oddly-pinnate, with 3-15 toothed or entire leaflets. Flovers small, racemed or panicled, from the axils of the last year's leaves, the American representatives diocious and apetalous; calyx and corolla, when present, as described for the order; anthers large, linear or oblong; style single, stigma 2-cleft. Fruit a 1-2-celled, flattened samara, winged at the apex, 1-2 pendulous seeds in each cell.

(The ancient Latin name of the Ash; supposed to be from the Greek $\varphi \rho \alpha^{\prime} \xi$ is, a separation, alluding to the facility with which the wood splits.)

\section{I0. FRAXINUS AMERICANA, L.}

White Ash.

Ger., Amerikanische Esche; Fr., Frêne Américain; Sp., Fresno Americano.

Specific Characters:- - Leaves pinnately compound with 7.9 leaflets, which are petiolate, ovate or lance-oblong, pointed, entire or obscurely toothed, pale shining above, smooth or pubescent beneath; petioles glabrous; branchlets smooth, gray, and buds rust-colored, somewhat velvety. Flowers (April, May) in loose, axillary, compound panicles, diœcious, apetalous, calyx minute and persistent. Fruit (August, September) a samara, terete and marginless at the base, extending above into a lanceolate, oblanceolate, or wedge-linear, often slightly emarginate wing. 
A tree of good size, though not often over $100 \mathrm{ft} .(30 \mathrm{~m}$.$) in height,$ with a trunk $3 \mathrm{ft}$. $(0.91 \mathrm{~m}$. $)$ in diameter.

Habitat. - Canada and United States generally, east of the Mississippi river and south nearly or quite to the gulf coast. It is said to reach its greatest development in the Ohio river basin.

Physical Properties. - Wood rather heavy, very strong and springy, hard, compact; sap-wood, when well seasoned, nearly white; heart-wood of a light reddish color, usually more or less mottled. Specific Gravity, 0.6543; Percentage of Ash, 0.42; Relative Approximate Fuel Value, 0.6516; Coefficient of Elasticity, 101668; Modulus of Rupture, 861; Resistance to Longitudinal Pressure, 463; Resistance to Indentation, 1\%1; Weight of a Cubic Foot in Pounds, 40.78.

UsEs. - A very useful timber in the manufacture of wheels, axles, shafts, and frames for wagons, carriages and cutters, for agricultural implements, oars, sweeps, etc., where great strength and stiffness or springiness are required.

Medicinal Properties. - It is noted by Mr. Geo. B. Emerson* that "an Ash leaf rubbed upon the swellings caused by mosquito bites and bee stings will remove the itching and soreness immediately, and it is reported by some that the leaf will also give relief in cases of snake bite. A decoction of the leaves is said to be an antidote to the poison of lambkill (Kalmia angustifolio), when taken by lambs."

Order ULMACË: † Elm Family.

Leaves simple, alternate; stipules caducous. Flowers perfect or polygamous by abortion, apetalous, in loose clusters, not catkins; calyx somewhat bell-shaped, free from the ovary; stamens springing from the calyx, usually as many as its lobes and opposite them; filaments straight, ovary 1-2-celled with a single suspended ovule in each cell; styles or stigmas two. Fruit, a samara or drupe with suspended seed; no albumen.

Represented by trees, rarely shrubs.

\section{GeNus ULMUS, L.}

Leaves short-petioled, usually rather rough, markedly straight-veined, unequally or obliquely heart-shaped or abrupt at the base; stipules small, caducous. Flowers appearing before the leaves in our species, purplish or yellowish, apetalous, polygamous, in lateral clusters or racemes; calyx 4-9-cleft; stamens 4-9, with long, slender filaments; ovary 2-celled, or rarely 1-celled, compressed; styles 2 , short and diverging. Fruit a samara with a broad, membranous margin, 1-celled by obliteration, and 1-seeded; seed with no albumen, large cotyledons and straight embryo.

(Ulmus is the ancient Latin name of the Elm.)

\section{ULMUS FULVA, Michx.}

\section{Slippery Elm, Red Elm, Moose Elm.}

\section{Ger., Rothe Ulme; Fr., Orme gras; Sp., Olmo Colorado.}

SPECIFIC Characters:- Leaves ovate-oblong, taper-pointed, unequally cordate at the base, rather irregularly doubly-serrate, very rough above and slightly rough

* Trees and Shrub. of Massachusetts, 2 d ed., pp. 379-380.

+ Ranked by some authors as a sub-order of the order Urticacea. 
or suft downy leneath, large, 4-8 in. long, and rugose, fracrant while dryingr;

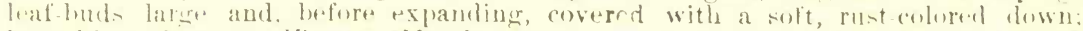

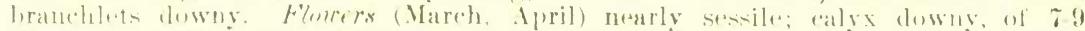

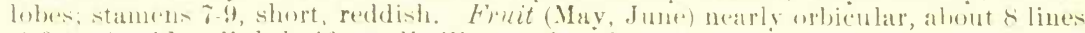
(1.9 cus.) wide, slightly if at all ciliate and with pubeserme e.ell.

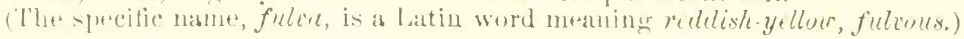

1 tree of medium size, ratrely of greater height that go ft. (21 m.) $\mathrm{m}$ of greater thickness of trunk than $2 \mathrm{ft}$. ( $(0.61 \mathrm{~m}$.), and with very mueilateinous inner batr.

HAliTaT. - Sollthern Canada and north-eastern United States, west-

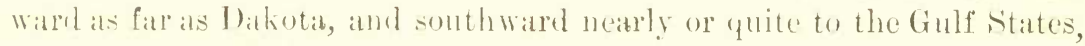
growing farticularly in rich and rather low grounds.

Physical P'rofentes.- - Wood heary, strong, compact and tough; beart-weod very latre, of brownish-red color; saj-wood thin and whitish.

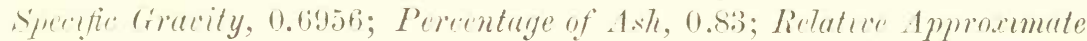
Fuel Value, 0.6898; Cuefficient of Elastirity, 95:25: Vodulus of Rupture, s69; Resistanee to Longitudinal Pressure, si39; Resstance to Indentation, 150; Weight of a C'ubic Foot in Poumels, 43.35.

UsEs. - This timber makes excellent fence rails. It is userl extensively in some localities in the mannfacture of the rumning-geatr of watgons, for seigh-runners ete. Its toughness and great flexihility when boiled or steamed malies it one of the very best of timbers for the ribs of eanoes atud sliffs.

A great item of value in this tree lies in its inner bark, which bears a copous mucilage. Aside from its important uses on melicine it is put matsonally to other uses as the following: - It is in a measure nutritious, imml has heen known to support life in cases of scareity of iood. We are toll by Mr. G. B. Enerson, * that lumng the War of 1s1\%, the troops along the Canalam frontier used it as ford for their horses when forage was seatree. It is reporter on the anthority of Dr. C. W. Wrightet of Cincimati, that "slppery-Elm hark hat the property of preserving fatty substances from rancility, a fact derived originally from the Indians, who prepatere bears fat by melting it with the batk, in the proportion of a drachm of the latter to a poumel of the formere kerpmes them heated towether for a few mintese and then strining off the fat." Dr. Wright

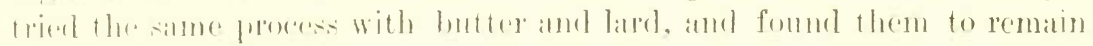
merforetly

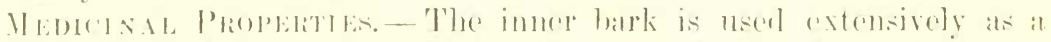

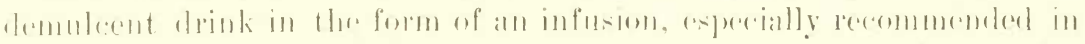

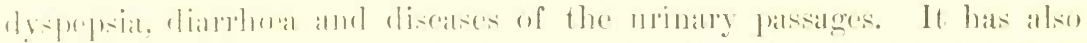

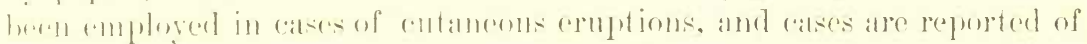

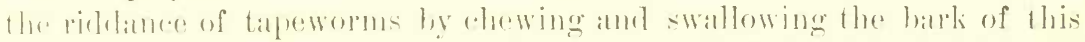

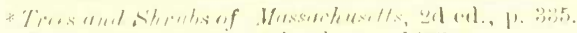

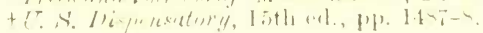


elm. As an emollient in the form of poultices etc., for inflammations it is also largely used, being prepared by simply treating the dried bark, either powdered or in a crude state, with hot water so as to be easily formed into a poultice.*

\section{Genus CELTIS, Tourn.}

Leaves pointed, somewhat oblique at the base. Flowers appearing with the leaves, greenish, axillary, monœciously polygamous; the staminate flowers in little fascicles or racemes; caly $\times$ 6-parted, stainens 6 ; the fertile flovers solitary or in pairs, pedunculate, calyx 5-parted, stamens 5, ovary 1-celled, styles 2, stigmas awl-shaped, elongated, recurved. Fruit a globular drupe, 1-seeded; seed containing a little gelatinous albumen, embryo curved, cotyledons crumpled.

(Celtis is the ancient Greek name of the Lotus.)

\section{CELTIS OCCIDENTALIS, L.}

Sugarberry, Hackberry, Nettle-Tree, False Elm.

- Ger., Abendländischer Zürgelbaum; Fr., Micocoulier occidentale; Sp., Almez Americano.

Specific Characters:- Leaves quite various in the different varieties but usually ovate, markedly taper-pointed from a broad, usually somewhat heart-shaped or truncate unequal or oblique base, reticulated, sharply serrate except sometimes vear the base, more or less rough above and pubescent at least when young beneath. F'lowers (April, May) solitary, sinall, white, with peduncles once or twice as long as the leaf stem; sepals triangular-ovate, erect. Fruit a small, solitary, round, sweet, edible drupe, dark purple when fully mature.

(Occidentalis, a Latin adjective meaning western.)

A tree usually of medium size and very variable aspect; sometimes like that of the Elm with spreading top; then, as often in northern New York, broadly ovate in outline, with numerous slender but long horizontal branches. In most favorable conditions of soil and climate it attains the height of $100 \mathrm{ft}$. $(30 \mathrm{~m}$.$) or more, with a trunk 5 \mathrm{ft} .(1.52 \mathrm{~m}$. in diameter. As the opposite extreme, it is found, in variety pumila, as scarcely more than a shrub. Thus we see it is a very polymorphous species and considering all its varieties of extensive

HaBitaT.- Southern Canada and the United States generally east of the Mississippi river, and said to attain its greatest development in the Mississippi basin. One form with small, thick and prominently reticulateveined leaves is found in south-western and western United States. The tree grows particularly along river flats, rarely, if ever, forming groves exclusive of other timber, or even of sufficient abundance to be generally known by casual observers.

Physical Properties. - Wood rather heavy, coarse-grained, not very hard or strong, compact, taking a good satiny polish, heart-wood usually brown, of various shades, often quite dark; sap-wood light and of 
a slightly yellowish or greenish tint. Specific Gravity, 0.7287; Percentage of Ash, 1.09; Relative Approximate Fuel Value, 0.7208; Coefficient of Elasticity, 6852\%; Modulus of Rupture, 789; Resistance to Longiludinal Pressure, 421; Resistance to Indentation. 21\%; Weight of a Cubic Foot in Pounds, 45.41.

UsEs. - Owing to the general scarcity of this tree, little can be said of its uses. It seems to be nowhere abundant enough to enter largely into any particular branch of manufacture. It is sometimes used by wheel-wrights, etc., as a substitute for Elm, with which it is allied in physical properties as well as botanically.

Medicinal Properties. - So far as known, this species is of no medicinal value.

No'rE. - Such is the general scarcity of these trees that they are usually looked upon, by the people at large, as strangers wherever found, and sometimes they become trees of considerable note.

One of this nature is found near the New York Central railroad, between Palatine Bridge and Spraker's, just north of the track and within the railroad enclosure. Ordinarily it would have been cut down when the road was laid, but the people residing in its vicinity petitioned the railroad authorities to let it remain. 'The request was granted, and the tree still stands, famous far and near in that section and to the railroad employes as the "Unknown Tree." Before visiting this tree to ascertain its identity, my father predicted that I would find it a representative of this species, remarking that he had several times, in his travels here and there in this country, been shown to what the people called "unknown trees," and in every case had found them to be of this species. I found him right in his prediction regarding this tree. It proved to be a fine specimen of its kind, $10 \mathrm{ft} .8 \mathrm{in} .(3.25 \mathrm{~m}$.) in girth, two ft. $(0.60 \mathrm{~m}$.) from the ground.

We know of two representatives of this species on the Black river bank, in northern New York, having variegated foliage.

\section{Order Platanacem: Plane-tree Family.}

Leaves simple, alternate, palmately-veined and lobed, with sheathing scarious stipules. Flowers monœecious, destitute of both calyx and corolla, in separate and globular heads. Sterile flowers numerous; stamens intermixed with small, clubshaped scales; filaments very short; anthers 2-celled, linear. Fertile flowers: pistils intermixed with little scales; ovaries inversely pyramidal; style simple, awl-shaped, stigmatic on one side. Fruit a small, club-shaped, coriaceous nutlet, with bristly, tawny down at its base, and containing a single, pendulous, albuminous seed.

Represented by trees.

\section{Genus Platanus, L,}

Characters as given for the order, this being the only genus.

(The name Plitanus is from the Gk., $\pi \lambda \alpha \tau v$ s, broad, probably in reference to the leaves.) 


\section{I3. PLATANUS OCCIDENTALIS, L.}

Sycamore, Plane-Tree, Buttonwood, Button-ball Tree. Ger., Amerikanische Platane; Fr., Platane Americain; Sp., Platano de America.

SpeCific Characters:- Leaves large, usually truncate at the base, angulate-lobed and commonly serrate-toothed, the lobes short and sharp-pointed; leaves and leafstems tomentose when young; stipules conspicuous, obliquely ovate; base of the petiole concave, covering the axillary bud. Flowers appear usually in May; fertile heads solitary, suspended on a long peduncle, and, persisting long after the leaves have fallen, give the tree a characteristic appearance in winter.

This is the largest (though not the tallest) deciduous tree of our American forests, sometimes attaining the enormous proportions of $120 \mathrm{ft} .(37 \mathrm{~m}$.$) in height, and 14 \mathrm{ft} .(4.27 \mathrm{~m}$.$) or more in diameter of$ trunk at base. The older bark of the trunk and large branches flakes off in brittle, irregular scales, leaving the surface of a whitish or grayish and more or less mottled color, especially in winter. Farther up, the smaller branches are often remarkable for their smoothness and whiteness, seeming quite as though white-washed. "This striking feature in winter enables one to observe the course of a stream for a great distance by the line of Sycamores along its banks." * The branches are greenish or brownish in color.

Haвiтat. - Southern Canada, New England, and southward nearly to the gulf coast, and westward to Kansas and Nebraska, reaching, perhaps, its greatest development along the Ohio river and its tributaries. It is partial to the river banks and localities where the soil is moist, often growing in or very close to the rocky beds of small streams which dry up in the summer season.

Physical Properties. - Wood heavy, rather hard and compact, though not very strong, difficult to split and work; of a reddish-brown color with light and somewhat yellowish sap-wood. Specific Gravity, 0.5678; Percentage of Ash, 0.46 ; Relative Approximate Fuel Value, 0.5652; Coefficient of Elasticity, 86402; Modulus of Rupture, 635; Resistance to Longitudinal Pressure, 450; Resistance to Indentation, 165; Weight of a Cubic Foot in Pounds, 35.39.

USES. - This timber, probably principally on account of the difficulty of working it, is not of extensive use in manufacturing. It makes good fuel when dry, and is used to some considerable extent in the manufacture of fruit baskets, tobacco boxes, etc., and to some extent for cabinetware. When cut with the "quarter" grain (in radial section), pieces of this timber give a very pretty effect in wooden mosaics and cabinet work.

* Elements of Forestry, by Franklin B. Hough, p. 252. 
For butchers' blocks, etc., where a timber is needed that will not split, it is admirable. When sawn into lumber it is said to warp badly.

A by no means unimportant use of this tree is its value as a shade-tree along public walks, etc., as it seems to endure the smoke and dust of cities better than most of our trees, is of rapid growth and casts a tolerably dense shade.

Medicinal Properties. - So far as known, none are possessed by this species.

NoTE.- My father once saw, in the state of Michigan, a fine tree of this species, noted in the locality as the "Crane-Tree" from the fact that it was the home of a colony of Great Blue Herons (Ardea herodias, L.) or "Cranes," as they are often wrongly called. In its top he counted some thirty of their nests.

\section{ORDER JUGLANDACEA: WALNUT FAMILY.}

Leaves alternate, pinnate and without stipules. Flowers monœcious and apetalous, except in some cases in the fertile flowers. Sterile flowers in catkins with an irregular calyx adnate to the scale of the catkin. Fertile flowers solitary or in small clus. ters, with calyx regularly $3-5$-lobed, adherent to the incompletely $2-4$-celled, but 1 . ovuled ovary. Fruit a sort of dry drupe (a tryma), with a fibrous and more or less fleshy and coriaceous outer coat (shuck) very astringent to the taste, a hard, bony inner coat (shell), and a 2-4-lobed seed, which is orthotropous, with thick, oily and of ten corrugated cotyledons and no albumen.

All representatives of the order are trees.

\section{Genus JUGLANS, L.}

Leaves odd-pinnate, with numerous serrate leaflets; leaf-buds few-scaled or nearly naked. Sterile flowers in long, simple, imbricated, axillary catkins from the wood of the preceding year; calyx unequally $3-6$-cleft; stamens $12-40$ witl very short and free filaments. Fertile flowers several in a cluster or solitary at the ends of the branches; calyx 4 -toothed and bearing in its sinuses 4 small petals; styles 2 , very short; stigmas 2 , somewhat club-shaped and fringed. Fruit drupaceous with a fibrous and spongy, somewhat fleshy, indehiscent epicarp (shuck), and a rough irregularly furrowed endocarp (shell); embryo edible and wholesome.

Trees with strong-scented resinous-aromatic bark and a pith which separates into thin transverse disks. (Juglans is contracted from Latin Jovis glans, the nut of Jove.)

\section{I4. JUGLANS CINEREA, L.}

\section{Butternut, White Walnut, Oil-Nut.}

Ger., Aschyrauer Wallnussbaum; Fr., Noyer cendré; Sp., Nogal gris.

SPECIFIC CHARACTERS:-Leaflets (15-17), oblong-lanceolate, pointed, rounded somewhat unequally at the base, pubescent especially beneath; petioles and branchlets clammy pubescent. Flowers (April, May) as described above, for order and genus. Fruit (Sept.) very claminy pubescent and of rather pleasant odor when fresh, oblong, pointed, 2-celled at base; the nut-shell deeply and irregularly furrowed leaving rough and ragged ridges; embryo very rich in oil and of delicious flavor.

A tree not usually growing tall (except when forced to in the forests, and then not to a great height), but of very wide spread, the trunk 
branching low down and sending out long horizontal branches. It is occasionally $80 \mathrm{ft}$. ( $24 \mathrm{~m}$.) in height, but usually considerably less, and with a trunk. 3 to $4 \mathrm{ft}$. $(0.90$ to $1.20 \mathrm{~m}$.) in diameter. Its short and wide-spread habit is very characteristic when growing in the open fields.

HАвгтат.- Southern Canada and north-eastern United States, westward to Minnesota and Iowa, and southward to Maryland or farther among the Alleganies. Grows in rich calcareous and not very moist soil.

Physical Properties. - Wood not strong, soft, compact, easily worked, taking a satiny and beantiful polish. Color light grayish-brown with white sap-wood, which is very thin in comparison with the colored heart. Specific Gravity, 0.4036; Percentage of Ash, 0.51; Relative Approximate Fuel I'ulue, 0.4065; Coefficient of Elasticity, 81253; Modulus of Rupture, 59\%; Resistance to Longitudinal Pressure, 392; Resistance to Indentation, 90; Weight of a Cubic Foot in Pounds, 25.46.

UsEs. - This timber though not of as high price in market as the allied Black Walnut, is nevertheless of great value for interior finishing, as wainscotings etc. It is to some extent used in furniture, and occasionally for other purposes.

Of quite as much value as the timber of this tree is its fruit, the nuts, which are gathered at about the time of the first frosts, and when properly dried are sweet and delicious. An expressed oil from these nuts is a drying oil very similar in properties to the linseed oil. The nuts gathered when young and succulent, at about the beginning of June, make excellent pickles, after removing the clammy pubescence by scalding and then rubbing with a coarse cloth.

The bark and the nut shucks are sometimes used for dyeing purposes, and from them, according to Mr. Emerson, black, brown, purple and fawn-color have been produced. The sap of this tree is quite rich in sugar, but not equal in value to that of the Sugar Maple.

Medicinal Properties. - The inner bark, particularly of the root, is officinally recognized as of value in medicine as a safe cathartic, very mild in its action. It is said that it was extensively employed by the physicians connected with the army in the Revolutionary war. Dysentery is a complaint in which it is particularly indicated. It is given in the form of a decoction or extract, the latter being officinal and usually preferred. The leaves, which are acrid, have been used when powdered as a rubefacient and sometimes as a substitute for Spanish flies.*

\section{ORDER CUPULIFERA: OAK FAMILY.}

Leaves alternate, simple, straight-veined; the stipules, forming the bud-scales, deciduous. Flovers moncecious, apetalous. Sterile flovers in clustered or racemed catkins (or in simple clusters in the Beech); calyx regular or scale-like; stamens 5-20.

* U. S. Dispensatory, 15 th ed., pp. 825-6. 
Fertile flowers solitary, clustered or spiked, and furnished with an involucre which forms a cup or covering to the nut; calyx-tube adherent to the ovary, its teeth minute and crowning the summit; ovary 2-7-celled with 1-2 pendulous ovules in each cell, but all of the cells and ovules, except one, disappearing before maturity; stig. mas sessile. Fruit a 1-celled, 1-seeded nut, solitary or several together, and partly or wholly covered by the scaly (in some cases echinate) involucral cup or covering: seed albumenless, with an anatropous, of ten edible, embryo; cotyledous thick and fleshy.

Represented by both trees and shrubs.

Genus QUERCUS, L.

Flowoers greenish or yellowish. Sterile flowers in loose, slender, naked catkins, which spring singly or several together from axillary buds; calyx 2-8.parted or cleft; stamens 3-12; anthers 2-celled. Fertile flovers with ovary nearly 3-celled and 6 -ovuled, 2 of the cells and 5 of the ovules being abortive; stigma 3-lobed; involucre developing into a hard, scaly cup around the base of the nut or acorn, which is 1-celled, 1 -seeded

(The ancient Latin name for the Oak supposed to be from the Celtic quer, fine, and cuez, tree.)

\section{I5. QUERCUS RUBRA, L.}

\section{RED OAK.}

\section{Ger., Rothe Eiche; Fr., Chêne rouge; Sp., Roble rojo.}

Spforfic Characters:- Leaves on long and slender petioles, abrupt or obtuse at the base, rather thin and smooth both sides when mature, oval or obovate in outline, moderately (rarely deeply) penatifid, with rounded sinuses and 7-9 narrow lobes these and the teeth being conspicuously bristle-pointed, turning dark red in autumn, whence the name " Red Oak." Flowers appear in May. Sterile with calyx 2-5-parted and 3-5 stamens. Fruit an acorn, requiring two years to reach maturity, and, therefore, found when mature on old wood below the leaves of the season, oblong-ovoid or turgid-ovoid, large, sometimes an inch in length, with bitter kernel and the abortive ovules at the apex of the seed, one-third immersed in the shallow saucer-shaped cup, which is $8-12$ lines in diameter, flat and broad with upturned edges, of fine firmly-appressed and smoothish scales, sessile or on a very short narrow stalk very much shorter than the acorn.

(The specific name, rubra, is the Latin for red.)

One of the largest and most beautiful of our Oaks, "giving an idea of nobility and great strength," and attaining the height of $80 \mathrm{ft}$. $(24 \mathrm{~m}$.) or more, with a trunk sometimes 6 or $7 \mathrm{ft}$. $(2 \mathrm{~m}$.) in diameter, and with a wide-spreading top. Its bark is smoother than with most of the oaks, and of a dark-gray color. It possesses an acrid, sour juice, which causes iron to corrode rapidly when in contact with it.

HABITAT. - A northern Oak; found generally throughout Canada and north-eastern United States, growing alike in rich and poor soils.

Physical Properties. - Wood heavy, hard, strong and coarsegrained, very liable to check in drying and of a light brownish or reddish color with lighter sap-wood. Specific Gravity, 0.6540; Percentage of Ash, 0.26; Relative Approximate Fuel Value, 0.6523; Coefficient of Elasticity, 112798; Modulus of Rupture, 990; Resistance to Longitudinal Pressure, 511; Resistance to Indentation, 17\%; Weight of a Cubic Foot in Pounds, 40.76 . 
UsES. - The timber of this species is of comparatively little economic value, excepting for fuel and in the manufacture of casks, tubs etc., and occasionally for interior finishing, chairs, etc.

It is a beautiful shade-tree, and its acorns are eagerly sought after by cattle and other domestic animals.

Medicinal Properties.-So far as known, none are possessed by this species.

\section{Genus Fagus, Tourn.}

Leaves undivided, strongly straight-veined, plaited lengthwise in the slender pointed buds, and growing in a light slender spray. Flowers appearing with the leaves. Sterile flowers yellowish, from the lower axils of the leaves of the season, in loose heads suspended by long slender peduncles and with deciduous, scale-like bracts; caly x 5-7-cleft, bell-shaped; stamens 5-16, with slender filaments and 2-celled anthers. Fertile flowers in pairs at the end of short peduncles, each pair invested with a 4-lobed involucre composed of more or less united, linear, soft, prickly scales; calyx with usually six minute, awl-shaped lobes; ovary 3 -celled with 2 ovules in each cell; styles 3, thread-like. Fruit a sharply 3 -angled, 1-seeded nut, enclosed, two together, within the involucral burr, which opens at maturity by 4 valves; embryo esculent and of very pleasant flavor; cotyledons thick.

(Fagus is probably from Gk., $\phi \alpha \gamma \varepsilon i \tau$, to eat, in allusion to the edible fruit.)

\section{I6. FAGUS FERRUGINEA, AIT.}

\section{American Beech.}

\section{Ger., Amerikanische Buche; Fr., Hêtre d’Amerique; Sp., Haya Americana.}

Specific Characters:-Leaves oblong. ovate, about one-half as wide as long, with short petioles, taper-pointed, obtuse or slightly cordate at the base, toothed with remote teeth, furnished with silky white hairs when young, but at length nearly glabrous, remaining late on the tree, sometimes during a part of the winter; buds with brown imbricated scales; stipules long and slender, falling early. F'lowers in May; the sterile cluster, with peduncle, about 2 in. long, pubescent. Fruit a small, ovoid, triangular nut, the prickles of its burr mostly recurved or spreading.

(The specific name, ferruginea, is a Latin adjective meaning dusky, ferruginous.)

A neat, handsome tree, always recognizable by its smooth, unbroken, bluish-gray bark. Occasionally a specimen is found $100 \mathrm{ft}$. $(30 \mathrm{~m}$.) or more in height, and its round, smooth trunk $4 \mathrm{ft}$. (1.22 m.) in diameter, but more commonly it is much smaller.

HaвiтAт. - Canada and north-eastern United States, westward as far as Wisconsin, and southward among the Alleganies to Georgia. Very common in the northern forests, growing in rocky and not very moist soil, and attaining, perhaps, its greatest development in Wisconsin, Michigan and in the forests generally about the Great Lakes.

Physical Properties. - Wood hard, tough, rather close-grained, strong, inclined to check in drying, taking a very smooth and beautiful polish; color reddish-brown of various shades; sap-wood nearly white, medullary rays large and conspicuous. Specific Gravity, 0.6883; Per- 
centage of Ash, 0.51; Relative Approximate Fuel Value, 0.6848; Coefficient of Elasticity, 120996; Modulus of Ruplure, 1148; Resistance to Longitudinal Pressure, 478; Resistance to Indentation, 196; Weight of a Cubic Foot in Pounds, 42.89.

UsEs. - This timber is nsed almost exclusively in the manufacture of plane-stocks. It is also used for shoe-lasts, and to considerable extent in the manufacture of chairs, table-legs, wooden-ware, tool-handles and turned-work generally. It is used, too, for ship-timbers to some extent. It makes very good fuel, leaving an ash that is rich in potassium.

The nuts of this tree, known as "Beech mast," are extensively eaten by squirrels, pigeons, gronse, ete., and the bear and deer find them dainty morsels. The deer of the Adirondacks, where this tree is abundant, grow fat in early summer on the young Beech "sprouts," which they find springing up in abundance everywhere along the hill-sides.

A fixed oil obtained from the nuts is similar in nature and properties to the Cottonseed Oil, and that of the European Beech ( $F$. sylvatica) ranks next to the Olive Oil in value for table use. Doubtless the American product is as valuable when properly prepared.

\section{ORDER BETULACEÆ: BIRCH FAMILY.}

Leaves simple, alternate, straight-veined and furnished with stipules which fall away early. Floners mostly naked, monœcious, both kinds in catkins, 2 or 3 together under a 3-lobed bract or scale. Sterile flowers with distinct stamens and 2-celled anthers. Fertile flowers with two thread-like stigmas, and a 2-celled ovary, each cell containing 2 pendulous ovules, becoming by abortion in Fruit, a small, 1-celled, 1 -seeded nutlet, often with inembranous wings; seed anatropous, albumenless, with flattish, oblong cotyledons which become foliaceous in germination.

Trees or shrubs, with bark which separates more or less easily into thin layers.

\section{Genus BETULA, Tourn.}

Leaves ovate, serrate; these, with the twigs, especially the latter, spicy-aromatic. Flowers appearing in early spring with or before the leaves. Stevile flowers in long, drooping, cylindrical, both terminal and lateral, yellow catkins, appearing in summer and remaining dormant du ring the following winter to open and perform their function early the next season; bracts 3-lobed, shield-shaped, and beneath each are 2 bractlets and 3 flowers with calyx represented by a mere scale, which bears the 4 short stamens, each with a single-celled anther. Fertile flowers in cylindrical or oblong catkins with 3-lobed scales, and beneath each scale are 2-3 naked pistils without braclets or calyx. Fruit a small, broadly-winged, scale-like nutlet or samara.

Trees and shrubs with outer bark horizontally fibrous and usually separable in sheets, that of the branchlets dotted, inner bark more or less aromatic and of pleasant flavor.

\section{I7. BETULA LUTEA, Michx. F.}

\section{Yellow Birch, Gray Birch.}

Ger., Gelbe Birke; Fr., Bouleau jaune; Sp., Abcdul amarillo.

Specinic Ciraracters:- Leaves thinnish, elliptical or ovate, somewhat tapepointed, often narrowed toward the rounded or slightly heart-shaped base, straight- 
veined, sharply and rather coarsely doubly serrate, smooth when old; petioles short and downy. The leaves in autumn, after the action of frosts, turn to a pale-yellow color. Sterile catkins 2-4 in. long, pendulous. Fruiting catkins sessile, erect, oblong-ovoid, 1 in. or less in length and $\frac{1}{2}$ to $\frac{8}{4}$ in. in thickness; scales of catkin nearly or quite $\frac{1}{2}$ in. long, rather thin, and with 3 subequal, acute and slightly diverging lobes.

(The specific name, lutea, is a Latin adjective meaning yellow, in allusion to the color of the bark.)

A tree invested with a yellowish, pearly or silver-gray outer bark, which peels off horizontally in thin strips or layers, and hangs loosely and ribbon-like, or is coiled up in rolls, giving old trunks a very ragged appearance. The inner bark, especially of the twigs, is pleasantly aromatic, of flavor quite similar to that of the Wintergreen. In forests it attains and sometimes surpasses the dimensions of $80 \mathrm{ft}$. (24 m.) in height and $3 \mathrm{ft}$. $(0.91 \mathrm{~m}$.) in thickness of trunk.

HaвiтAт. - A Northern species, found throughout north-eastern United States, Canada, New Brunswick and Nova Scotia, westward little, if any, beyond the Great Lakes, and southward to North Carolina and Tennessee, but there only among the Alleganies.

Physical Properties. - Wood hard, close-grained, tough, heary and very strong, compact, taking a beautiful satiny polish. Color light reddish-brown with nearly white sap-wood. Specific Gravity, 0.6553; Percentage of Ash, 0.31; Relative Approximate Fuel Value, 0.6533; Coefficient of Elasticity, 161723; Modulus of Rupture, 1248; Resistance to Longitudinal Pressure, 619; Resistance to Indentation, 161; Weight of a Cubic Foot in Pounds, 40.84 .

UsEs.-This wood is very valuable as fuel, and is used extensively by wheel-wrights and cabinet-makers. The three-ply chair bottoms in common use are made very largely of this timber. It is also valuable in the manufacture of the friction-pulleys, and the smallest wooden articles, such as clothes-pins, button and tasseI molds, pill-boxes, etc. Young saplings, cut lengthwise through the center, make excellent and strong hoops for casks, etc. Burls, or "knots" as they are often called, are not uncommon on this timber, although not often cut into veneering, as are those of the Black Ash and some other timbers. They are highly prized for mallets, beetles, etc. The bark is used to some extent for tanning purposes, and the rolatile oil, used for imparting the flavor of Birch to candies, soda-water, etc., is derived to some extent from this species, though mostly from the Sweet Birch (B. lenta).

Medicinal Properties. - None are recorded of this species.

\section{ORDER SALICACEAE. WILLOW FAMILY.}

Leaves alternate, simple, undivided and furnished with stipules, which are either scale-like and deciduous, or leaf-like and persistent. F'lowers diœcious, both kinds in catkins, one under each bract or scale of the catkin, and destitute of both calyx 
and corolla, or the former represented by a gland-like cup; ovary 1 - to 2-celled; styles wanting, or 2 and short; stigmas often 2-lobed. Fruit a 1- or 2-celled, 2 -valved pod with numerous seeds springing from 2 parietal or basal placentæe and furnished with long, silky down; seeds ascending, anatropous, without albumen; cotyledons flat.

Trees or shrubs of rapid growth, light wood and bitter baik.

\section{Genus POPULUS, TOURN.}

Leaves broad, more or less heart-shaped or ovate, and petioles, which are long and often vertically compressed. Flowers appearing before the leaves in long, drooping, lateral, cylindrical catkins, the scales of which are furnished with a fringed margin; calyx represented by an oblique; cup-shaped disk with entire margin; stamens, 8-30 or more, with distinct filaments; pistil with very short, bifid style, and large, 2-lobed stigma. Fruit as described for the order.

Represented by rather large trees. (A Latin word, meaning the people, and applicable either from the fact that these trees are often set along public walks, or in allusion to the tremulous leaves which are in constant agitation like a crowd of people.)

\section{I8. POPULUS GRANDIDENTATA, MichX.}

\section{Large-toothed Aspen or Poplar, White-wood.}

Ger., Groszgezänte Espe; Fr., Peuplier à grandes dents; Sp., Alano de diente grande.

Specific Characters:- Leaves roundish, ovate, with large and unequal sinnate teeth, densely covered with silky wool when young; smooth both sides when old; twigs terete (not angled as with some of the Poplars). Flovoers (May) in catkins 3-4 in. long, the sterile longer than the fertile, all the parts hairy, stamens about 12, catkin scales unequally 5-6-cleft, furnished with a slight, silky fringe. Fruit as described for the order.

(The specific name, grandidentata, is from Latin, grandis, large, and dens, a tooth, in allusion to the coarsely-toothed leaves.)

A medium-sized tree, rarely surpassing $75 \mathrm{ft}$. (23 m.) in height, or $2 \mathrm{ft} .(0.61 \mathrm{~m}$.) in diameter of trunk.

Ha BITAT. - Almost identical in range with the Yellow Birch, being found in Nova Scotia, New Brunswick, Canada and the northern States, westward as far as Minnesota, and southward along the mountains to North Carolina and 'Tennessee.

Physical Properties. - Wood soft, close-grained, light, compact, satiny and taking a smooth finish. Very white, when properly seasoned, excepting the heart, which is of a light-brown color. Specific Gravity, 0.4632; Percentage of Ash, 0.45; Relative Approximate Fuel Value, 0.4611; Coefficient of Elasticity, 96327; Modulus of Rupture, 721; Resistance to Longitudinal Pressure, 358; Resistance to Indentation, 62; Weight of a Cubic Foot in Pounds, 28.8\%.

UsES. - This tree seems hitherto not to have been ranked as high in the scale of economic value as it deserves, but the reason lies doubtlessly in the fact that it is never of very great size, and it seems to have been overlooked in the abundance of Pines, Tulips, Basswoods, etc., which 
this country affords. It is not liable to shrink, and would be valuable for inside finishing, for which use it is sometimes employed. It is used to considerable extent in turned-work and smaller wooden-ware generally. A clothes-pin manufacturer in northern New York tells us that he considers the Poplar as the best timber for his use. It enters largely into the manufacture of tooth-picks and excelsior, but its principal use might be said to be in the manufacture of wood-pulp for paper, and for this it is of highest value, being considered, perhaps, second to none in importance.

- "When, in the time of our grandmothers, fashion required that a lady should seem somewhat taller than nature made her, the light wood of this poplar was in demand as best adapted for the substance of the high heels of their shoes, and the manufacture constituted a distinct trade. The more substantial heels of the shoes of the lower people were made of more durable and heavier maple. The wood was also extenisively used in the manufacture of hats before the palm-leaf was introduced." *

Medicinal Properties. - None are recorded for this species.

\section{GYMNOSPERM $\nexists$.}

Flowering, exogenous plants with leaves chiefly parallel-veined and cotyledons frequently more than two. Flowers diclinous and very incomplete; pistil represented by an open scale or leaf, or altogether wanting, with ovules naked, fertilized by direct contact with the pollen, and seeds at maturity naked - without a true pericarp.

\section{ORDer CONIFERA: Pine Family.}

Leaves mostly awl-shaped or needle-shaped, evergreen, entire and parallel-veined. F'lowers monoecious, or rarely diœcious, in catkins or cones, destitute of both calyx and corolla; stamens one or several (usually united); ovary, style and stigma wanting; ovules one or several at the base of a scale, which serves as a carpel, or on an open disk. Fruit a cone, woody and with distinct scales, or somewhat berry-like, and with fleshy coherent scales; seeds orthotropous, embryo in the axis of the albumen.

Trees or shrubs with a resinous juice.

Genus PINUS, TourN.

Leaves evergreen, needle-shaped, from slender buds, in clusters of 2-5 together, each cluster invested at its base with a sheath of thin, membranous scales. F'lowers appearing in spring, monœcious. Sterile flowers in catkins, clustered at the base of the shoots of the season; stamens numerous with very short filaments and a scale-like connective; anther cells, 2, opening lengthwise; pollen grains triple. Fertile flowers in conical or cylindrical spikes - cones - consisting of imbricated, carpellary scales, each in the axil of a persistent bract and bearing at its base within a pair of inverted ovules. Fruit maturing in the autumn of the second year, a cone formed of the imbricated carpellary scales, which are woody, of ten thickened or awned at the apex, persistent, when ripe dry and spreading to liberate the two nut-like winged seeds; cotyledons $3-12$, linear.

(Pinus is a Latin word from Celtic pin or pen, a crag.)

* The Trees and Shrubs of Massachusetts, by Geo. B. Emerson, 2d ed., p. 279. 


\title{
I9. PINUS RESINOSA, AIT.
}

\author{
Red Pine, "Norway" Pine. \\ Ger., Harzige Fichte; Fr., Pin rouge; Sp., Pino rizadlo.
}

Specific Characters:-Leaves 5-8 in. (13-20 cm.) long, dark-green, arranged in pairs, with a close sheath 6-12 lines (1-3 cm.) in length, enveloping the base of each pair. Fruit an ovoid-conical, terminal cone, with rounded base, about 2 in. $(5 \mathrm{~cm}$.) or more in length, and with slightly thickened, awnless scales, falling after shedding the seeds which are slightly ridged beneath; cotyledons 6-7.

(The specific name, resinosa, is the Latin for resinous.)

A tree of handsome, vigorous aspect, commonly attaining the height of $80 \mathrm{ft}$. ( $24 \mathrm{~m}$.) or more, with a straight, uniform trunk $2 \mathrm{ft}$. $(.61 \mathrm{~m}$.) in diameter and covered with reddish bark, which constantly flakes off, when old, in rather small, irregular scales.

HaвiтAт. - Northern United States and Canada, southward as far as into Pennsylvania, and said to reach its greatest development in Michigan, Wisconsin and Miunesota, growing in dry, sandy loam, particularly along ridges.

Physical Properties. - Wood light, not very strong, elastic, resinous and durable, harder than the White Pine, with yellowish-white sapwood, slightly reddish heart and very conspicuous grain. Specific Gravity, 0.4854; Percentage of Ash, 0.2\%; Relative Approximate Fuel Value, 0.4841; Coefficient of Elasticity, 113216; Modulus of Rupture, 800; Resistance to Longitudinal Pressure, 455; Resistance to Indentation, 85; Weight of a Cubic Foot in Pounds, 30.25.

UsEs. - The principal value of this timber is in its usefulness for flooring, wainscoting, etc., for which its hardness renders it excellent. It is also used in localities for pump-logs, piles, ship-building, etc. Notwithstanding the inference one might draw from the specific name, resinosa, resinous, very little, if any, of the resin or turpentine of commerce comes from this tree.

Medicinal Propertiss. - None are ascribed to this species.

\section{GENUS ABIES, TOURN.}

Leaves evergreen, solitary, scattered (not clustered nor sheathed at the base), short, all of one kind and foliaceous. F'lowers appear in spring. Sterile flowers in catkins, scattered, or somewhat clustered in the axils of the leaves of the preceding year. Fertile flowers in catkins or cones, which are lateral or terminal on the shoots of the preceding year. Fruit a cone, maturing in the autumn of the first year, otherwise quite as deseribed for Cenus Pinus, excepting the scales are thin and flat (neither thickened nor furnished with a spur at the apex); seed with a persistent wing; cotyledons 3-9.

(Abies is an ancient Latin name of the Fir-tree.) 


\title{
20. ABIES NIGRA, POIR.
}

\author{
Black Spruce, Double Spruce, Red Spruce. \\ Ger., Schwartztanne; Fr., Epinette noire; Sp., Abeto negro.
}

Specific Characters:-Leaves short, needle-shaped, about 6 lines $(1.27 \mathrm{~cm}$.) or slightly more in length, 4 -sided, and scattered thickly over the branches, pointing every way. Sterile flowers appear in May, having anthers tipped with a rounded, recurved appendage, and cells distinct, openiog lengthwise. Fruit an ovoid or ovoid-oblong cone, 1-18 in. $(2.5-4.5 \mathrm{~cm}$.) in length, usually recurved, persistent, with inconspicuous bracts and elliptical-obovate scales, which are rigid and persistent on the axis, with thin scales, usually eroded or ragged tip.

('The specific name, nigra, is the Latin for black.)

A tree commonly attaining the height of $80 \mathrm{ft}$. (24 m.), with a straight, columnar trunk of $2 \mathrm{ft}$. $(0.61 \mathrm{~m}$.) or more in diameter, covered with a rather smooth, bluish-brown bark, which flakes off when old in small scales. The top often develops in a pyramidal form, with branches falling below a horizontal line growth.

Habitat.- Northern United States, Canada and northward, forming in some localities large tracts of forest. It occurs southward as far as Pennsylvania, and sparingly among the mountains to North Carolina.

Physical Properties. - Wood light, soft, elastic, strong, compact and satiny, often of slightly reddish tint, and with lighter, nearly white, sap-wood. Specific Gravity, 0.4584; Percentage of Ash, 0.2\%; Relative Approximate Fuel Value, 0.4572; Coefficient of Elasticity, 10998\%; Modulus of Rupture, 747; Resistance to Longitudinal Pressure, 407; Resistance to Indentation, 7\%; Weight of a Cubic Foot in Pounds, 28.5\%.

UsES.- This timber is of great value in the manufacture of lumber for many uses, especially for flooring, coping, general house-building, ship-building etc. It is used largely for piles and for the spars of vessels it is considered invaluable. One very important use is in the manufacture of sounding-boards for pianos, violins and other stringed instruments, for which use the "quarter" grain lumber, $i$. e., lumber cut on radial section, is always used. It is said by instrument makers that few if any timbers equal the Spruce in value for this use. It is one of the best of timbers on account of its combined lightness and stiffness for canoe paddles, oars for shells, etc.

A resinous exudation from this tree is valued as a chewing-gum, and meets with such ready sale that the gathering of it is quite an industry, at least in the vicinity of our home in northern New York, from which section hundreds of pounds are gathered annually and shipped to market.

Medicinal Properties. - An essence of Spruce is made by boiling the young branches of this tree in water and evaporating the decoction. It is used in the manufacture of spruce beer, which is a pleasant and 
wholesome beverage, especially in summer, and it is sometines useful on long seat-royages as a preventive of reurry, *

\title{
21. ABIES CANADENSIS, Мıнх.
}

\author{
HeMLOCK, II:ULOCK HIR.
}

Ger., Sthierting-Tanne; Fr., Peruche; Sp., Abeto Camadense.

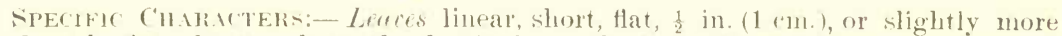
in length, Hat, obtuse, olscurely dentieulate, whitened beculath, short-petioled and diverging in opposite directions from the sides of the branchlet. Florers appear in May, sterle florers in shatl globose catkins each of a fow capitate anthers whoset short ronfluent cells open transversely; pollen grains simple. Fruit small ovoid cones, scarcely longer than the leares, pendent from the tips of the branches of the preceding year, persistent, will inconspienous brats, and of few, thin, rounded, entire scales, which are persistent on the axis.

A handsome tree, sonetimes attaining the dimensions of $100 \mathrm{ft}$. (30 m.) in height with a trunk 3 ft. (0.91 m.) in diameter, quite straight and covered with firm, rielged bark. The sprays of young vigorous trees are peculiarly light and gracefut in appearance, of dark green color above and showing in pretty contrast the whitish under surfaces, when turned up by the winds. The heauty is enlanced in early summer by each branchlet being tipped with the delicate light-green new shoots of the scilsoll.

HabJat.- North-eastern Inited States generally, Camada, New Brunswick and Nova scotia, southward to North Carolina and 'Tennessee amone the momntains and, according to Dr. Nohr, into Slabama. A very ahmolant tree in many of the forests of the north-east.

Phisical, Propertes. - I Iood light, rather soft and brittle, coarsegrained and not very asily worked, of a light, somowhat reddish or limowish color, with lighter silp-woor and eonspicuons grain. Specific Gravity, 0.:439: I'erontaye of $1 \times h$, 0.46; Relatice Apmoximate Funl Falue, 0.4.20; Cofficient of Elastirity, 895\%0; Hodulus of Rupture, r36; liesistance to Longitudinal Pressure, :8st; Resistance to Indentation, Sz; Wright of a culbie: Foot in l'ounts, 26.4\%.

l'sEs. - This timber is estensively amplopent throughout its range for joists, rafters, planks amb siling for buikling purposes, fences, plankwalhs etce, for which use it is invaluable. Lath are extensively mate of this timber, and many trees of small size are felled for railroad ties.

Perhaps the principal point of value of this tree lies in its bark, which is very rich in tammm, and in the north it is by far the chiof source of that produce for tamming leather. 
Medicinal Properties. - A resinous exudation of this tree, known in Pharmacopœia as Pix Canadensis, Hemlock Pitch or Canada Pitch, is a gentle rubefacient very similar to the Burgundy Pitch, and, like that, is used in the preparation of stimulating plasters for application in cases of chronic rheumatic pains, chronic affections of the chest, etc.* This Hemlock must not be confounded with an herb of the same name - the Poison Hemlock (Conium maculatum) - whose medicinal properties are entirely different.

\title{
22. ABIES BALSAMEA, MaRshall.
}

\author{
Balsam, Balsam Fir, Balm-of-Gilead Fir.
}

Ger., Balsam-Tanne; Fr., Sapin baumier; Sp., Abeto balsamico.

Specific Characters:-Leaves linear, flat, obtuse, 9 lines $(1.90 \mathrm{~cm}$.) or slightly more in length, emarginate or entire, bright-green above, the mid-rib prominent along the glaucous-silvery under surface, nearly sessile, spirally arranged, but at once diverging to either side, making a flat spray. Flowers in May or June. Sterile flowers with anthers tipped with a 1-2-pointed appendage, and the cells opening by laceration; pollen quite as in the Pine. Fruit, cones, which are erect, cylindrical, large $2-4$ in. $(5-10 \mathrm{~cm}$.) long, violet-colored, with slightly projecting, obovate serulate, mucronate bracts; these, with the broad, compact scales, deciduous from the persistent axis at maturity.

(The specific name, balsamea, is the Latin for balsamic.)

A tree rarely more than $80 \mathrm{ft}$. ( $24 \mathrm{~m}$.) in height, or with a trunk more than $2 \mathrm{ft} .(.61 \mathrm{~m}$.) in diameter, and even these dimensions are reached only under most favorable circumstances. It is covered with a smooth bark raised, everywhere about the trunk, in blisters, which hold each from a drop or two to nearly a half teaspoon of a thick, transparent, viscid fluid, which is the Canada Balsam or Balm of Fir of commerce. The branches grow out usually in whorls of about five each, with great regularity, and, diminishing in length from below upwards, develop into a perfectly pyramidal top with a symmetry and compactness that is very striking, and giving to "Balsam swamps" a characteristic aspect.

Habitat. - North-eastern United States and Canada, southward to Virginia, westward beyond the Mississippi, and far northward, growing in swamps and cold, damp woods.

Physical Properties. - Wood very soft, light, not strong nor durable, coarse-grained, remarkably easily split and very satiny, whitish with slightly reddish tin to heart and very distinct grain. Specific Gravity, 0.3819; Percentage of Ash, 0.45; Relative Approxımate Fuel Value, 0.3802; Coefficient of Elasticity, 81924; Modulus of Rupture, 515; Resistance to Longitudinal Pressure, 365; Resistance to Indentation, 75; Weight of a Cubic Foot in Pounds, 23.80. 
USES. - Lumber is manufactured from this tree to but very slight extent and is little used. Its handsome form and vigorous growth makes it useful, especially while young, as an ornamental shade-tree and in the formation of wind-breaks.

The boughs of this tree are sought by the Adirondack sojourner for the construction of his bed, as they are more springy and suitable than any thing else at hand - and delightful beds they do make. The fragrance with which they fill the camp is delicious, and in that alone he feels largely repaid for the labor his trip has cost him. A pillow made from these boughs is oftentimes carried home to serve, by its perfume, as a reminder during the coming winter of the happy associations of his camp-life and especially of the balsam-bed.

\section{Gends LARIX, TouRn.}

Leaves needle-shaped, soft, deciduous, in clusters of many each, from lateral scaly buds excepting along the shoots of the season, where they are scattered. Sterile flowers terminating lateral scaly buds or spurs on shoots of preceding year, with 2-celled anthers opening longitudinally; pollen grains, simple and globular. Fertile flowers in catkins - cones - red while in flower, consisting of several or many carpellary scales springing from the axils of bracts, and bearing each 2 ovules with orifices turned downward. Fruit an erect, oval or roundish cone, with colored persistent scales, and maturing the season of blossoming.

(Larix is the Latin classical name of the Larch.)

\section{LARIX AMERICANA, MICHX.}

\section{Tamarack, American or Black Larch, Hackmatack.}

\section{Ger., Amerikanische Larche; Fr., Meleze Americain; Sp., Larice}

\section{Americana.}

Specific Characters:- Leaves filiform, short - about 1 in. $(2.54 \mathrm{~cm}$.) in length and very slender. Cones deep purple, ovoid, $\frac{8}{2}$ in. $(1.90 \mathrm{~cm}$.) or less in length, with scales few, rounded, thin and inflexed on the margin.

A beautiful tree, not often exceeding $80 \mathrm{ft}$. $(24 \mathrm{~m}$.) in height, of peculiar aspect, with slender tapering and very straight trunk, rarely over $2 \frac{1}{2}$ ft. $(0.76 \mathrm{~m}$.) in thickness of base, horizontal symmetrical branches and thin lightish green foliage, which in autumn turns to a soft yellow color. The bark is of a bluish gray color, and like that of the Spruce flakes off when old in small roundish scales.

Habitat. - North-eastern United States, north of Pennsylvania and northward nearly or quite to the Arctic Regions, probably reaching its greatest development in Canada, where it grows on moist uplands. In the United States it is confined mostly to cold swamps interspersed usually with the Balsam.

Specific Characters. - Wood heary, strong, hard, compact and durable, of light brown color with lighter sap-wood and conspicuous bold grain. Specific Gravity, 0.2636 ; Percentage of Ash, 0.33; Relative 
Approximate Fuel Value, 0.6215; Coefficient of Elasticity, 126126; Modulus of Rupture, 901; Resistance to Longitudinal Pressure, 536; Resistance to Indentation, 112; Weight of a Cubic Foot in Pounds, 38.86.

Uses.-A favorite wood in ship-building especially when gotten out as "natural crooks" for knees and similar timbers, for which its durability and toughness render it very valuable. It makes excellent fence-posts, telegraph-poles etc., and is one of the very best of our timbers ior railway ties. So much is it in demand for those purposes that we do not ofteu see it sawn into lumber.

Medicinal Properties. - The inner bark of the European Larch possesses astringent and slightly stimulant properties, and is supposed to have a special tendency to the mucous membranes. It has been found efficacious in the treatment of bronchitis, hæmoptysis and of catarrhal affections generally of the pulmonary and urinary passages.* Doubtless the American species, which is closely allied to the European, would be found to possess the same medicinal properties.

Note.-A “Tamarack Swamp," as occasionally seen in the Adirondack region, presents a very singular appearance. They are often found bordering ponds and beaver-meadows, and in such tracts Tamarack is often the only timber found. Then the absence of underbrush, the delicate light-green foliage, the rather pyramidal-shaped tops and straight trunks form striking features. But especially is one impressed with the way in which the branches grow out only above a certain level, a little higher than one's head, and that level is as accurately defined in every tree as though it were a high-water mark.

Another impressive feature is the soft yielding carpet of sphagnum moss which covers the ground, and into which one sinks ankle-deep as he walks. He can scarcely hear the sound of his own foot-steps, and the oppressive silence is only broken by the sighing of the wind through the tree-tops, or perhaps by the sweet song of the White-throated Sparrow, which is common in those localities. Such a swamp once visited is long remembered.

\section{Genus THUJA, TouRN.}

Leaves evergreen, small and scale-like, closely imbricated and appressed, so as to make flat two-edged branchlets. Flowers (May, June) monœcious, in terminal very small ovoid catkins. Sterile catkins with scales imbricated, filaments scale-like bearing each 4 anther-cells. Fertile catkins consisting of a few carpellary scales without bracts, and bearing each two erect ovules with orifices turned upward, becoming in Fruit a small dry cone, as described above, opening at maturity; seeds winged; cotyledons two.

( $T$ 'huja is from Greek, $q v v^{\prime}$, to burn perfumes in allusion to the fragrance of the smoke.)

*U. S. Dispensatory, 15th ed., p. 844. 


\title{
24. THUJA OCCIDENTALIS, L
}

\author{
Arbor-Vita, White Cedar. \\ Ger., Amerikanische Lebendbaum; Fr., Thuja d' Occident; Sp., Tuya \\ Occidental.
}

Specific Characters:-Leuves in four rows, appressed as described for the genus and flattened horizontally, all on the same branchlet lying in approximately the same plane and making a spreading, fan-like spray. Cones scarcely $\frac{1}{2}$ in. (1.27 cm. ) in length, oblong, with loose, truncate scales, and of a light-brown or brownish-yellow color; seeds winged all round.

(The specific name, occidentalis, is the Latin for western, meaning here of the Western Hemisphere.)

A tree not often over $60 \mathrm{ft} .(18 \mathrm{~m}$.) in height with a thick trunk, sometimes $4 \mathrm{ft}$. $(1.22 \mathrm{~m}$.) in diameter at base, rapidly diminishing in size upwards, and frequently somewhat curved at the base. The heart-wood is of light-brown color, often with a slightly reddish tint; sap-wood, which is very thin, lighter.

Ha BITAT. - Northern United States and north ward to British America, southward little, if any, beyond the latitude of central Pennsylvania, excepting along the mountains. It is found in swamps and along river banks and lake shores, where the soil is considerably moist. A very abundant tree in many sections.

Physical Properties.-- Wood very light, soft and close-grained, compact, not strong, easily split and durable. It possesses a rather pleasant and characteristic odor. Specific Gravity, 0.3164; Percentage of Ash, 0.3\%; Relative Approximate Fuel Value, 0.3152; Coefficient of Elasticity, 53311; Modulus of Rupture, 512; Resistance to Longitudinal Pressure, 306; Resistance to Indentation, 60; Weight of a Cubic Foot in Pounds, 19.7\%.

UsES. - The principal use of this timber is for fence-posts and telegraph-poles, for which it is excellent and very extensively used. It is among the best of our timbers on account of its lightness, as well as other good qualities, for the siding of skiffs, canoes etc., which must be light in order to be easily carried over portages. We have seen one made of this wood, and weighing only $10 \frac{1}{2} \mathrm{lbs}$, yet large enough to carry one man and baggage over quiet waters, - probably the lightest wooden craft ever used in navigation. Such is the lightness, durability and strength of this timber. White Cedar is largely used for shingles, and to some extent for pails, buckets etc.

As an ornamental tree, particularly for hedges, it is very useful. For the latter use it is often employed, and, when rightly attended to, is scarcely surpassed in compactness and neatness.

Medicinal Properties. - A decoction or tincture of the leaves of this tree is sometimes used in intermittent fevers, coughs, scurvy, rheu- 
matism etc. Made into an ointment, with lard or other animal fat, it is sometimes successfully used as an external application in rheumatism and other local complaints. A volatile oil, extracted from the leaves, is sometimes successfully used as a remedy for worms.*

\title{
Genus JUNIPERUS, L.
}

Leaves evergreen, opposite or in whorls of three, rigid and of two forms, one awlshaped and the other scale-like, often both found on the same bush or tree. Flowers diœcions, rarely monœecious, in very small catkins. Sterile catkins ovate, with shieldshaped scales, each bearing at its base 3-7 anther-cells. Fertile catkins ovoid or globose, with few (3-5) fleshy, concave, united scales, each bearing one ovule, and these together becoming in Fruit a sort of berry, but in reality an altered cone, scaly-bracted underneath, blackish or bluish in color, and furnished with a lightercolored bloom, and containing from 1-3 bony, wingless seeds; cotyledons, two.

(Juniperus is the classical Latin name of the Juniper.)

\section{JUNIPERUS VIRGINIANA, L.}

\author{
Red Cedar, Savin, Pencil Cedar. \\ Ger., Virginischer Wacholder; Fr., Genevrier; Sp., Sabina.
}

Leaves mostly opposite, small, connate-decurrent (not articulated) on the stem in four ranks, and of two forms, one acutish, scale-like, imbricated and closely appressed, making a flat, two-edged branchlet, the other awl-shaped, sharp-pointed, nearly $\frac{1}{2}$ in. $(1.27 \mathrm{~cm}$.) in length, loose and spreading. Fruit a small berry a little larger than a pepper-corn, dark blue, covered with a whitish powder, erect on the branchlet.

(Virginiana, Lat. for Virginian, but applied to the species when "Virginia" meant much more territory than at present.)

A tree sometimes $80 \mathrm{ft}$. ( $24 \mathrm{~m}$.) in height and $3 \mathrm{ft}$. $(0.91 \mathrm{~m}$.) or more in thickness of base, but usually much smaller. It is ordinarily of a short pyramidal form with branches springing from near the ground and reaching far out horizontally, but in some localities, noticeably along the banks of the Hudson river for example, it assumes a very slender, trim pyramidal form, or almost lanceolate in outline, with rounded base and smooth straight trunk several feet in length before branching. The foliage is of a dark-green color, and the bark on old trunks has usually a ragged appearance, the outer layer peeling off vertically in light ribbon-like strips and swinging loosely in the wind.

Habitat. - Of very extensive geographical distribution, being found from Canada southward to the peninsula of Florida, and westward to the Rocky Mountains, although unknown in many localities within these limits, probably owing to unfavorable conditions of soil or atmosphere. In the north of its range it is found growing along rocky limestone ridges, but in the south often in swamps. 
Physical Properties. - Wood light, soft, close-grained. compact, not strong, easily worked and one of the most durable of our timbers in contact with the soil, strongly and pleasantly odorous, of a dull-red color inclining somewhat to purple and fading on exposure to a purplishbrown; sap-wood thin and whitish. Specific Gravity, 0.4926; Percentage of Ash, 0.13; Relative Approximate Fuel Value, 0.492; Coefficient of Elasticity, 66992; Modulus of Rupture, 740; Resistance to Longitudinal Pressure, 416; Resistance to Indentation, 148; Weight of a Cubic Foot in Pounds, 30.\%0.

UsES. - This is the timber from which lead-pencil cases are almost exclusively made. Its great durability in contact with the soil ranks it as probably the best of our timber's for fence posts, railway ties, sills, etc., when large enough. It is used to some extent in interior finish, and for caskets and cabinet work. For bureau drawers and the like it is particularly suited, owing to the fact that its odor tends to keep away moths.

Medicinal Properties. - The tops, $i$. e. the leaves and twigs, of this tree possess stimulant, anthelnintic and other properties. Made into a cerate and applied externally it acts as a valuable irritant. It is sometimes substituted for the European Sarine, but is less effectual in its action. The berries possess diuretic properties.* 


\section{INDEX.}

(For Index to the Structural Botany Treated in the Introduction, see p. 26.)

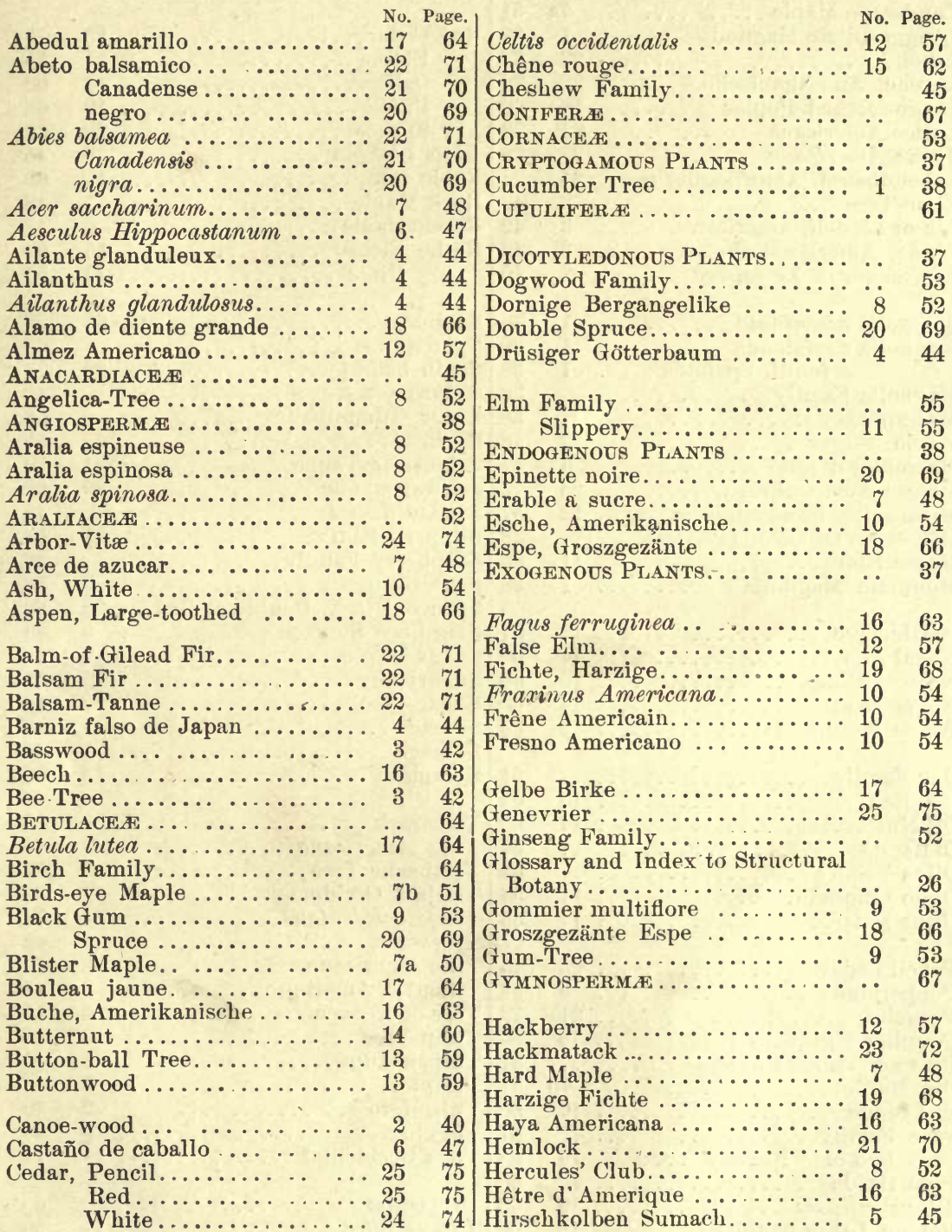


No. Page,

Horse Chestnut ............ 648

JugLANDACEA .............. 60

Juglans cinerea .............. 1460

Juniperus Virginiana.........25 75

Key, Based upon Flowers........ 30

Fruit ......... 34

Leaves......... 32

Landscape Maple.......... 7a 51

Langgespitzte Magnolia ........ 1,38

Larch.................. $23 \quad 72$

Larche, Amerikanische........ 2372

Large-toothed Poplar ......... $18 \quad 66$

Larice Americana ........... 23

Larix Americana ............ 23

Lebendbaum, Amerikanische ... 24

Lime-Tree............... 3

Lin or Linden, American ..... . 3

Linde, Amerikanische......... 3

Liriodendron Tulipifera........

Magnolia acuminata .......... 1

Magnolia acuminada .......... 1 à feuilles pointes ..... 1

Magnolia Family............

Magnoliace $\ldots \ldots \ldots \ldots \ldots \ldots . . . . .38$

Maple, Sugar............ 7

Marronier d' Inde ........... 6

Meleze Americain............ 23

Micocoulier occidental ........ 12

Monocotyledonous Plants ... . .

Moose Elm ............... 11

Mountain Magnolia.......... 1

Nettle-Tree................. 12

Nogal gris............... 14

Norway Pine $\ldots \ldots \ldots \ldots \ldots \ldots . \ldots . \ldots$

Noyer cendré.............. 14

Nyssa multiflora............ ?

Oak Family.................

Red.................. 15

Oil-Nut ................... 14

OLEACE

Olive Family ...............

Olmo Colorado.............. 11

Orme gras................ 11

Pencil Cedar................. 25

Pepperidge............... 9

Peruche $. . . \ldots \ldots \ldots \ldots . . .21$

Peuplier à grandes dents ...... 18

Phanogamous Plants ..........

Pin Maple............... $7 \mathrm{~b}$

Pin rouge ................ 19

Pine Family.......... • ...

Red or "Norway"....... 19

Pino rizado............... 19

Pinus resinosa.............. 19

Poplar, Large-toothed ......... 18

Populus grandidentata........ $18 \quad 66$

Plane-Tree ............... $13 \quad 59$

Plane-Tree Family............... 58

Platanace............... 58

Platane Americain.......... $13 \quad 59$

Platane, Amerikanische ....... $13 \quad 59$

Platano de America ............ $13 \quad 59$

Platanus occidentalis.......... 13 . 59

Quercus rubra ............ $15 \quad 62$

Red Cedar................. $25 \quad 75$

Elm................. $11 \quad 55$

Oak ................... 15

Pine ................ 1968

Spruce.............. $20 \quad 69$

Rhus typhina............... $5 \quad 45$

Roble rojo................ $15 \quad 62$

Rock Maple.............. 748

Roszkastanie ............. 647

Rothe Eiche.............. $15 \quad 62$

Ulme $\ldots \ldots \ldots \ldots \ldots \ldots .115$

Sabina ................... $25 \quad 75$

SALICACEA................ 65

Sapin baumier............. $22 \quad 71$

SAPINDACEA ............... 46

Sauer Gummibaum ........... 953

Savin ........................ 2575

Schierling-Tanne ............ 2170

Schwartztanne ............. $20 \quad 69$

SimaRUBACEA $\ldots \ldots \ldots \ldots \ldots \ldots . \ldots . \ldots$

Slippery Elm............. $11 \quad 55$

Soapberry Family............. 46

Sour Gum................. 53

Spruce, Black, Double or Red... $20 \quad 69$

57 Stag-horn Sumach .......... $5 \quad 5 \quad 45$

60 Sugar Maple............... $7 \quad 48$

68 Sugarberry.............. $12 \quad 57$

60 Sugar-'Tree ............... $7 \quad 48$

53 Sumac ................. $5 \quad 45$

Sumach................. $5 \quad 45$

Sycamore $\ldots \ldots \ldots \ldots \ldots \ldots \ldots \ldots$

Tamarack ................ $23 \quad-72$

Tilia Americana................. 34

Toothache-Tree............ 8 52

55 Thuja d'Occident ............. $24 \quad 74$

55 Thuja occidentalis............ $24 \quad 74$

THIIAcen................. 42

Tilio Americano.............. 342

Tilleul d' Amerique ............ 342

Tree-of-ILeaven .............. 444

6 Tulip-Tree ................ 240

37 Tulpenbaum ................ 240

51 Tulipier.................. 240

68 Tulipifero $\ldots \ldots \ldots \ldots \ldots \ldots \ldots \ldots . \ldots 240$

67 Tupelo................... 953

Tuya Occidental ............. $24 \quad 74$

Ulmace $\ldots \ldots \ldots \ldots \ldots \ldots \ldots \ldots$

66 Utmus fulva.............. 11 55 
No. Page.

No. Page.

Wacholder, Virginischer .......25

75 Willow Family ............. 65

Wallnussbaum, Aschgrauer..... 14

Walnut Family .

60

White Ash .................... io

Cedar.............. 24

Poplar.. ............ 2

Walnut ............. 14

White-wood................. 2

60 Yellow Gum............... 953

$54 \quad$ Poplar.............. 240

74

40 Zürgelbaum, Abendländischer .. $12 \quad 57$

White-wood................ 18

40 Zumaque.... ............. $5 \quad 45$ 


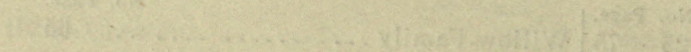

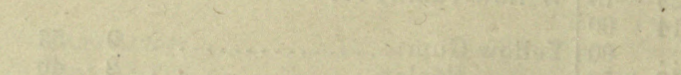



1. MAGNOLIA ACUMINATA, $L$.

Cucumber-Tree, Mountain Magnolia,

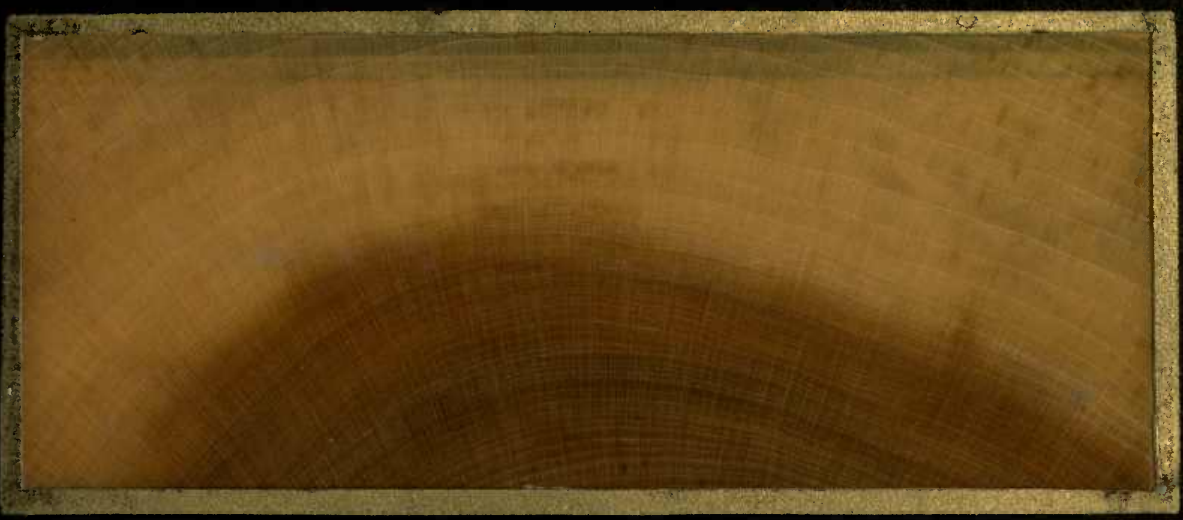

TRANOVERER SEOTION.

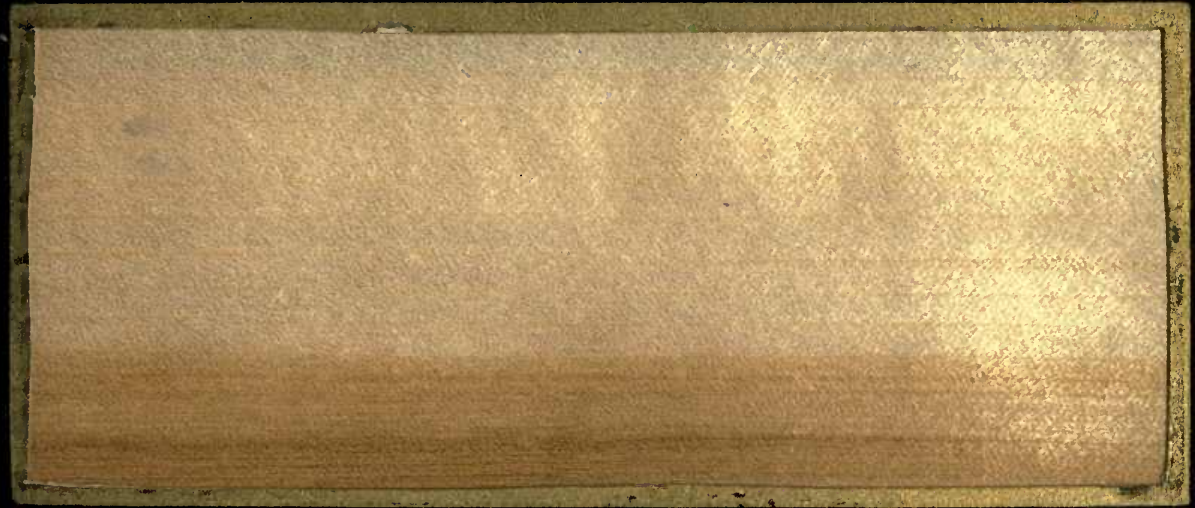

havial gEGTION.

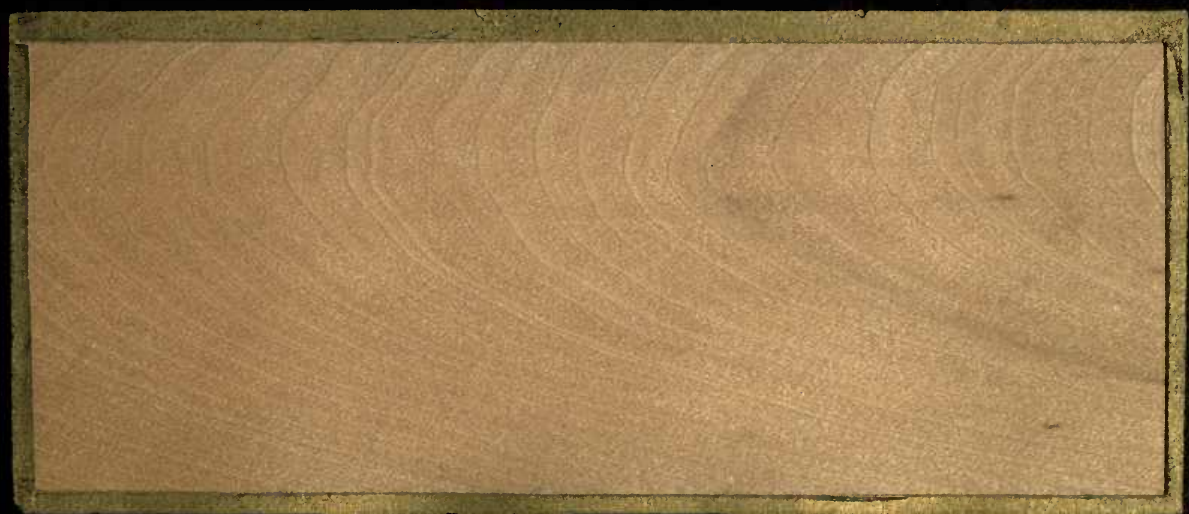

TAMGENTIAL SEOTION.

Ser. Langgespitzte Magnolia. S S. Magnolia acuminada Fi.Magnolia à fouilles pointes. 
1. MAGNOLIA ACUMINATA, L.

Cucumber-Tree, Mountain Magnolia。

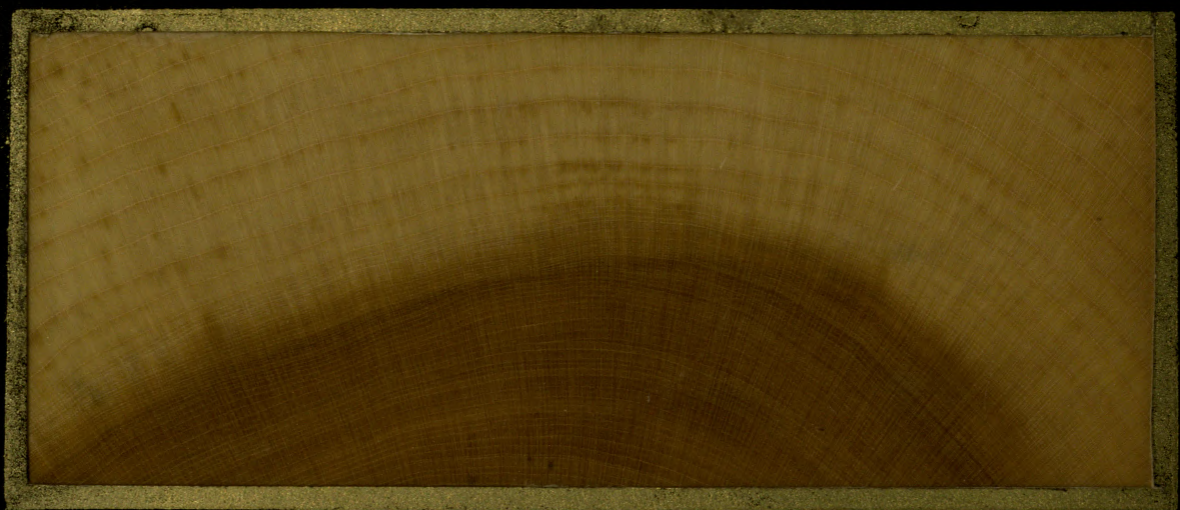

TRANSVERSE SECTION.

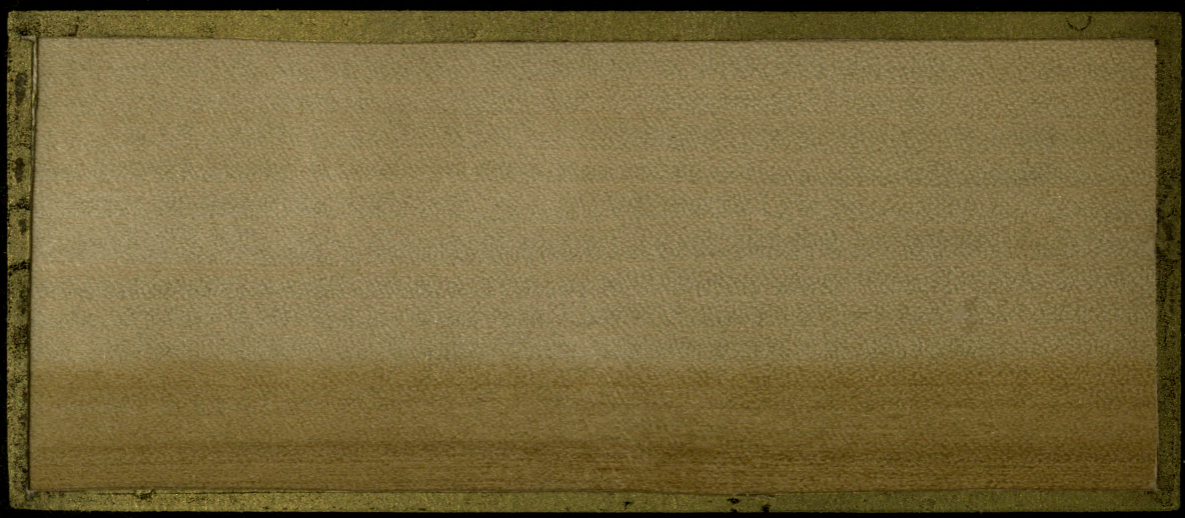

nabiat gEcitow.

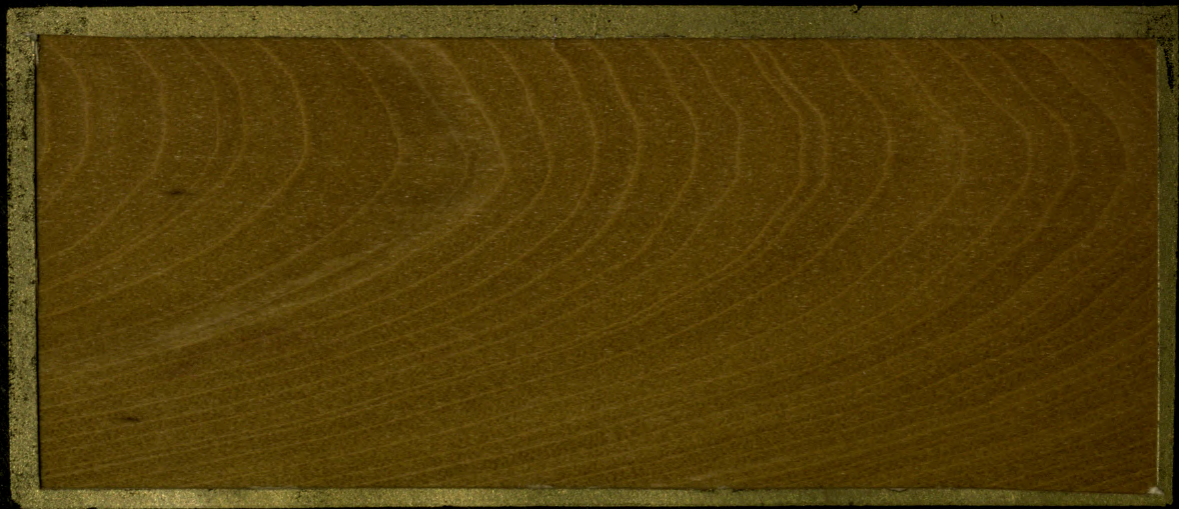

TAMGENTIAL BECTIOM.

Ser. Langsespitzte Magnolia. S̀. Magnolia acuminada $\breve{F}^{\prime}$, Magnolia à feuilles pointes. 
2. LIRIODENDRON TULIPIFERA, L.

Tulip-Tree, White-Wood, White or Yellcw "Poplar," anoe-Wood.

TRAMSVERSE SECTION.

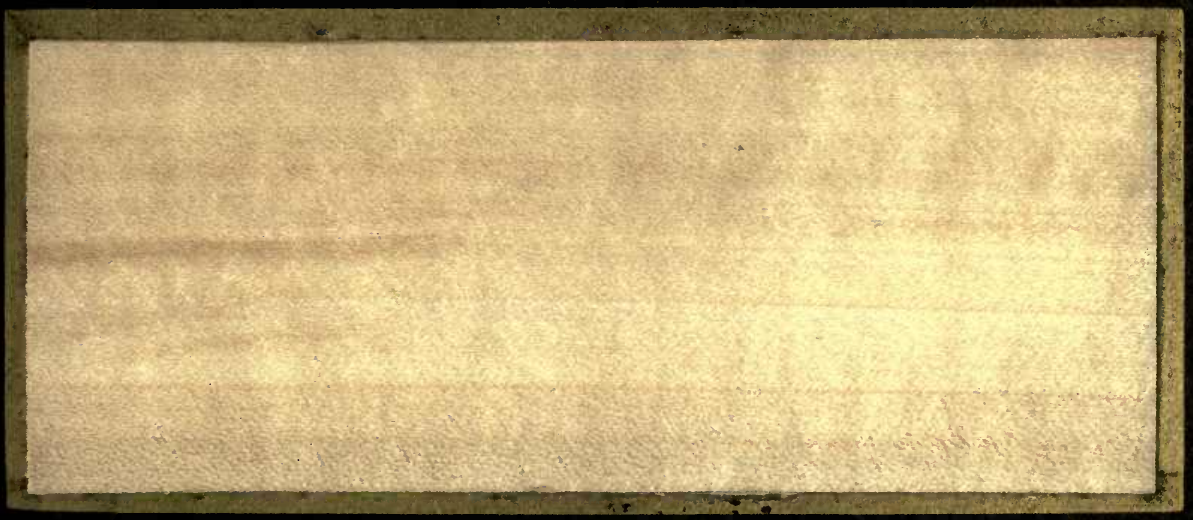

RADIAL SEOTION.

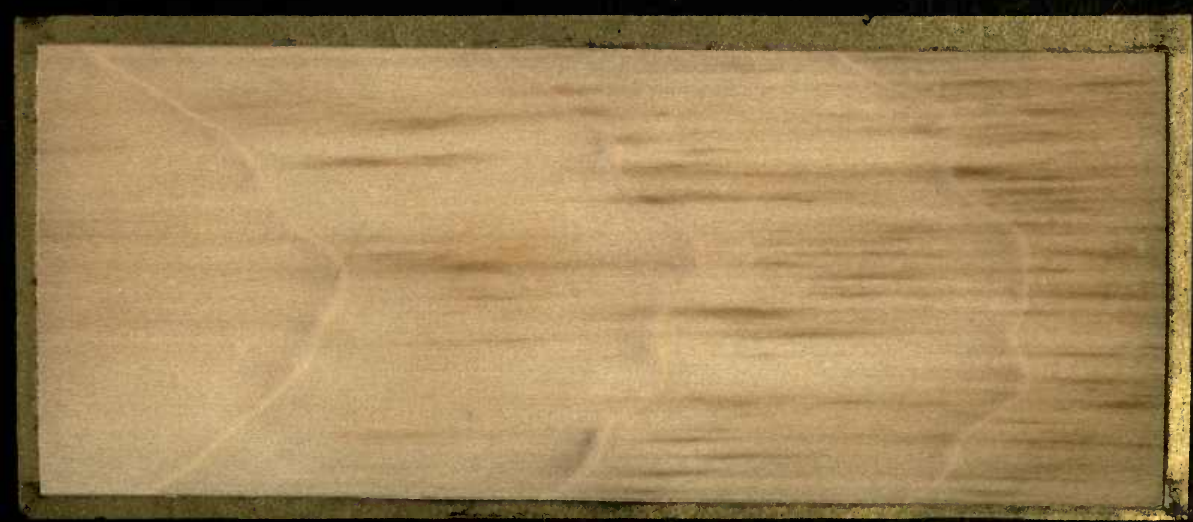

TANOENTIAL SEOTION.

Sen, Tulpenbaum, Sitr, Tulipier, Sp, Tulipifero, 
2. LIRIODENDRON TULIPIFERA, L.

Tulip-Tree, White-Wood, White or Yellow "Foplar" mop-Wood.

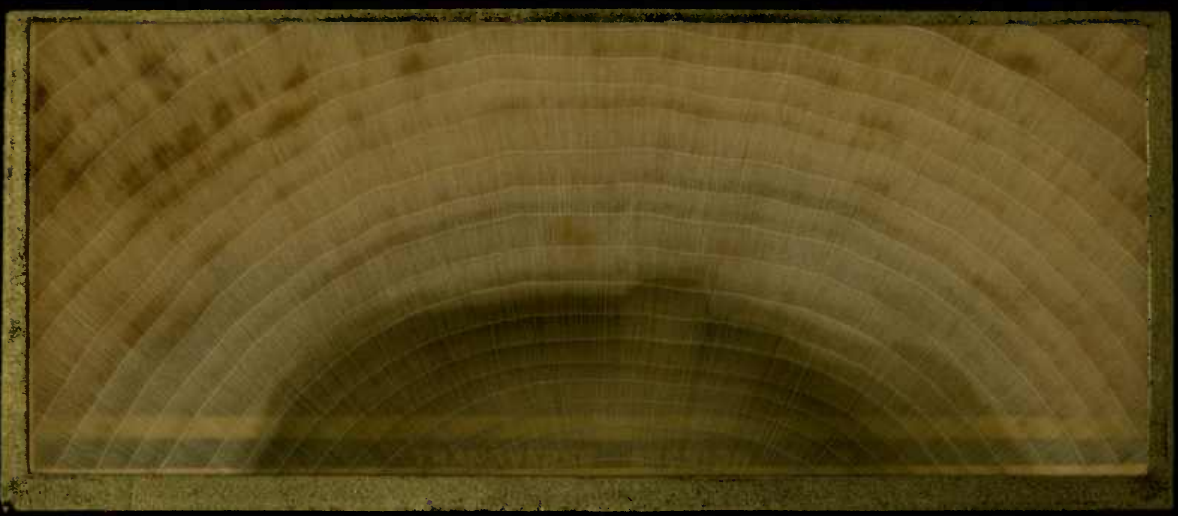

TRANSVERSE SEGTION.

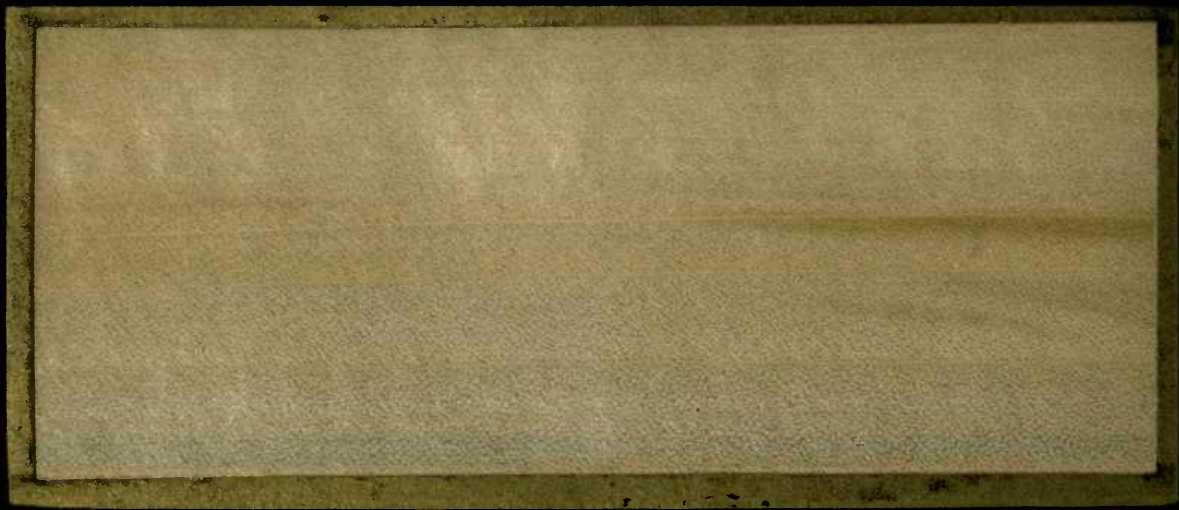

RADIAL SEOTION.

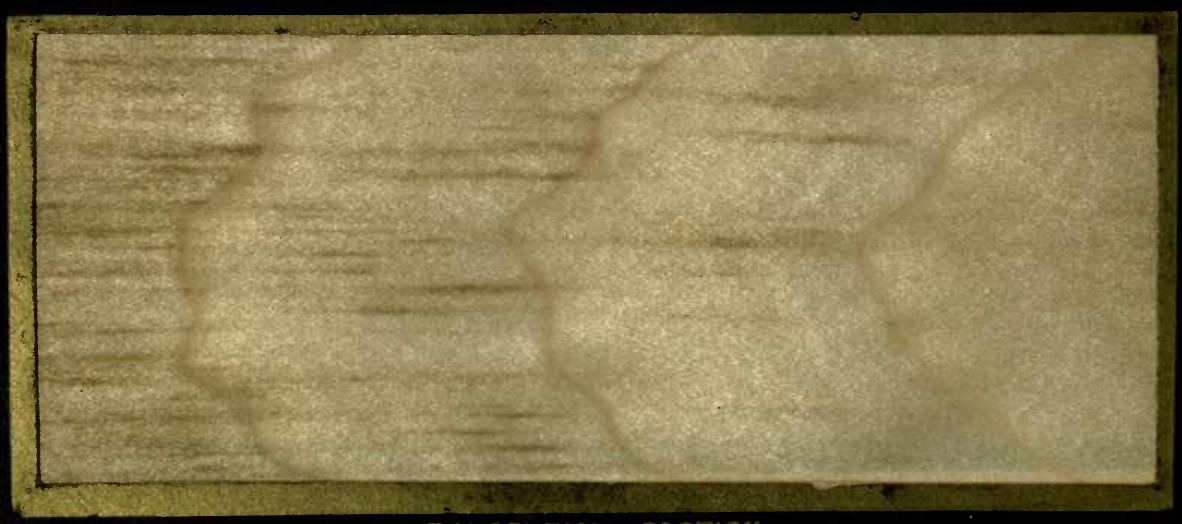

TANOENTIAL SEGTION

Sen. Tulpenbarm. Sơn. Tulipier. Sp, Tulipifero. 
3. TILLA AMERICANA, L.

Bassrood, Amexican Linden or Lin, Lime-Tree, Bee-Tree.

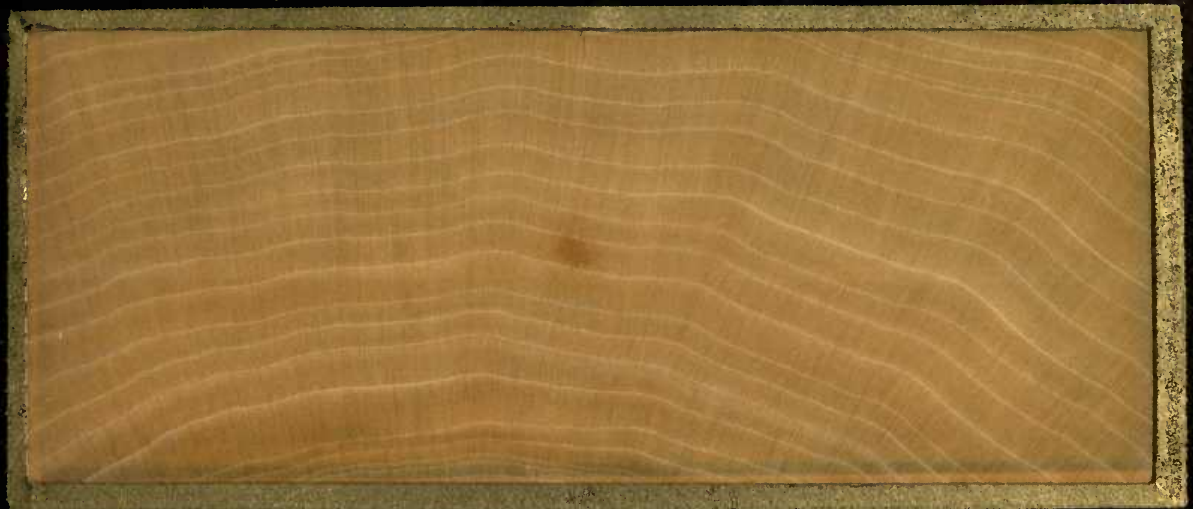

TRAMEVERE SEGTIOW. 


\section{TILIA AMERICANA, L.}

Basswood, Amorioan Linden or Lin, Lime-Treo, Bec-Tros,

TRAMBVERSE SEGTION.

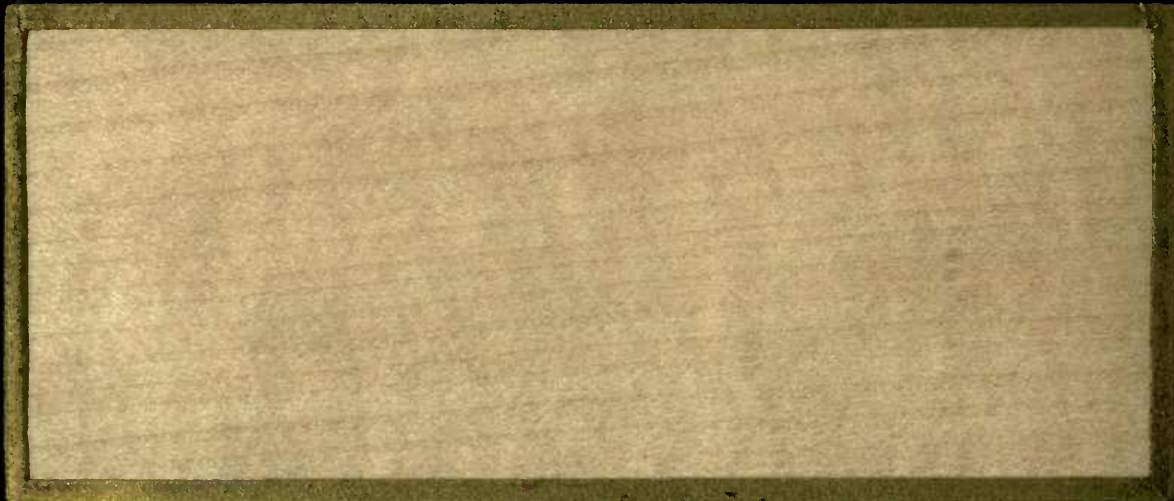

RADIAL BEGTHOM.

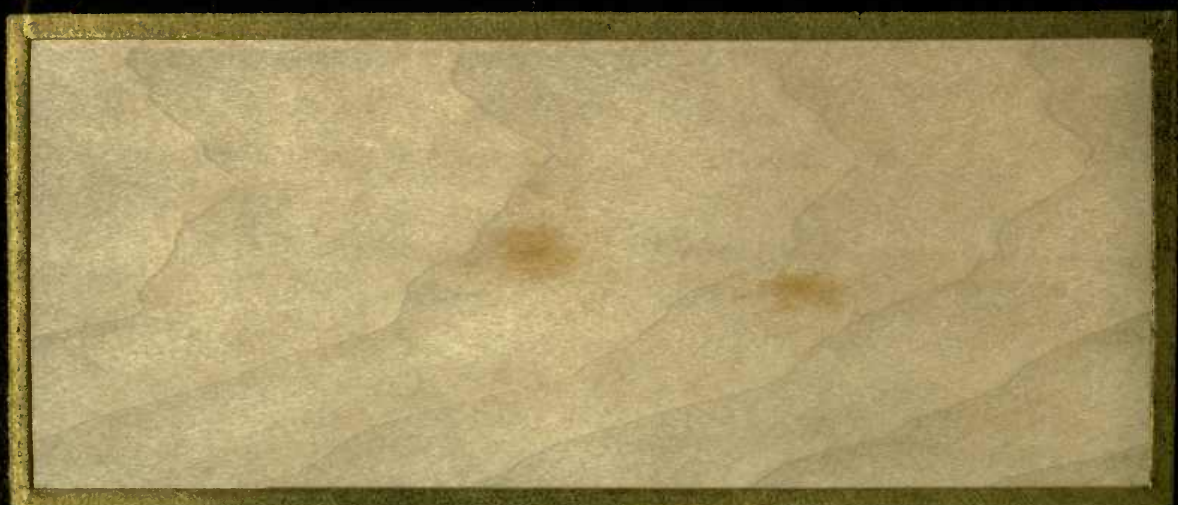

TAMSEMTHS BEGTIOM.

Ser Amerikanische Linde, Sp, Tilio Americano.

The Tilluel d'Amerique.

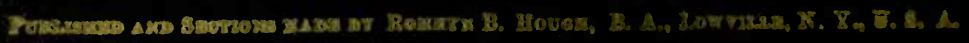


4. AILANTHUS GLANDULOSUS, DESF. Ailanthus, Tree-of-Fearean

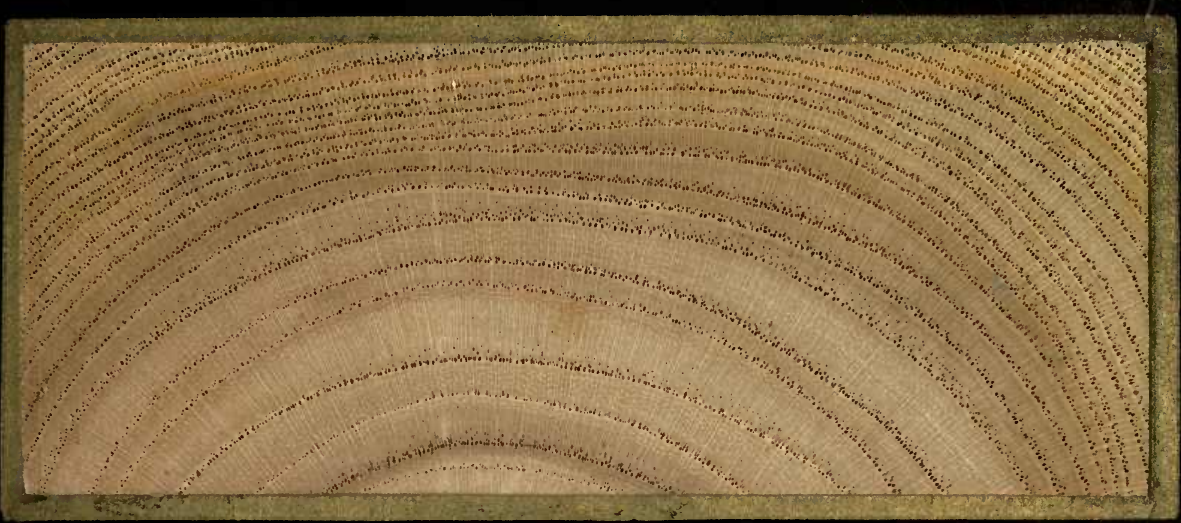

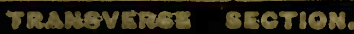

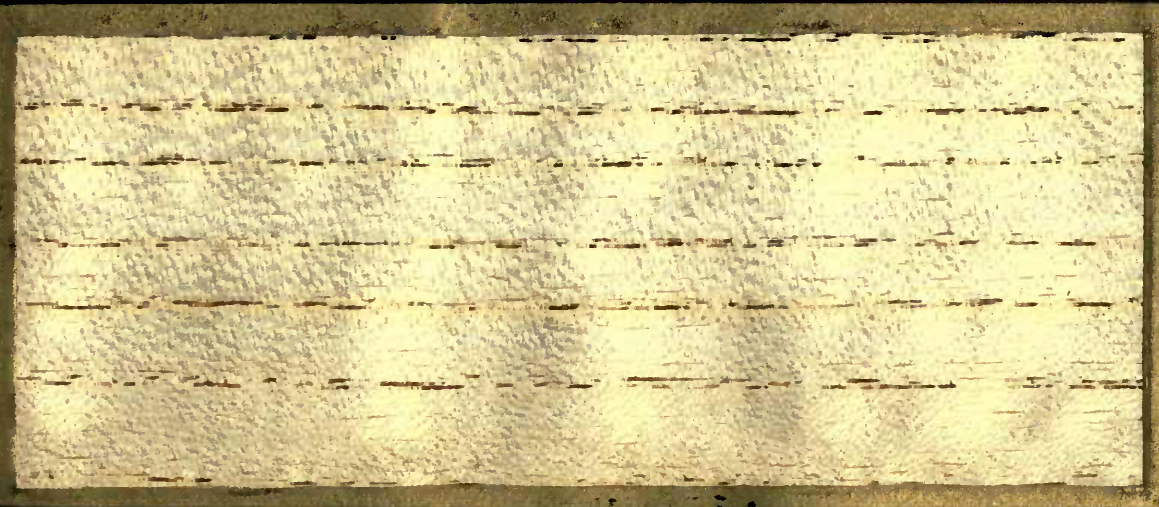

Badah azertos.

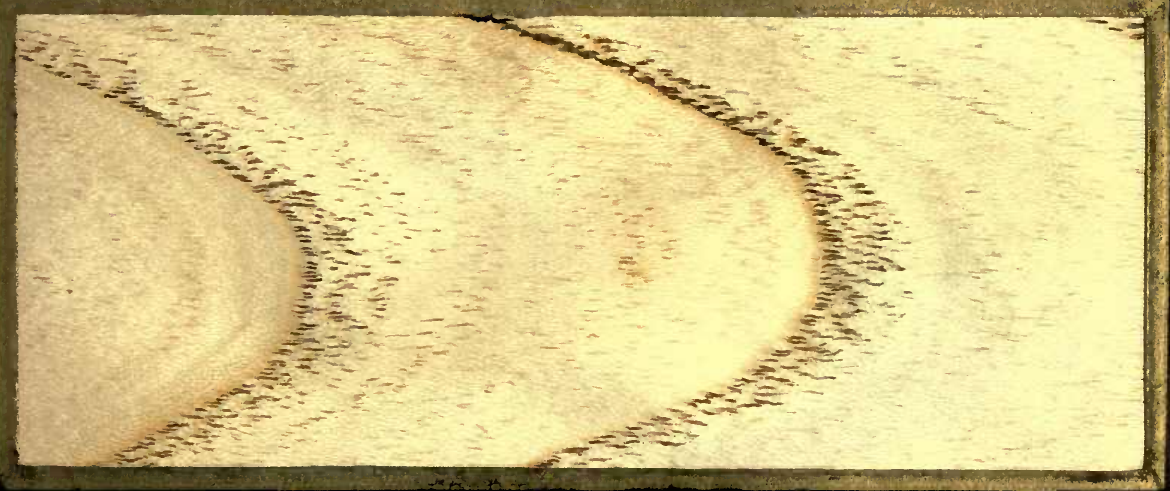

TANGENTAR ERETON.

Ser Drüsiger Gö́tterbaum.

Sp. Barniz falso de Japan. This. Aylante glaudnleux. 
4. AILANTHUS GLANDULOSUS, DESF。

Ailanthus, Tree-0f-Heaven.

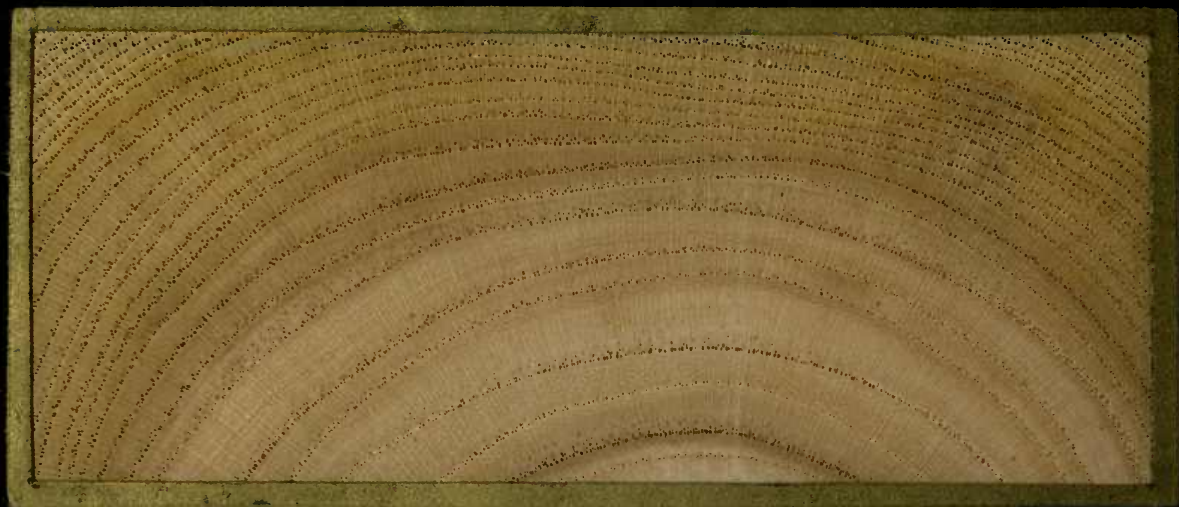

TRAMOERSE SEOTIOW.

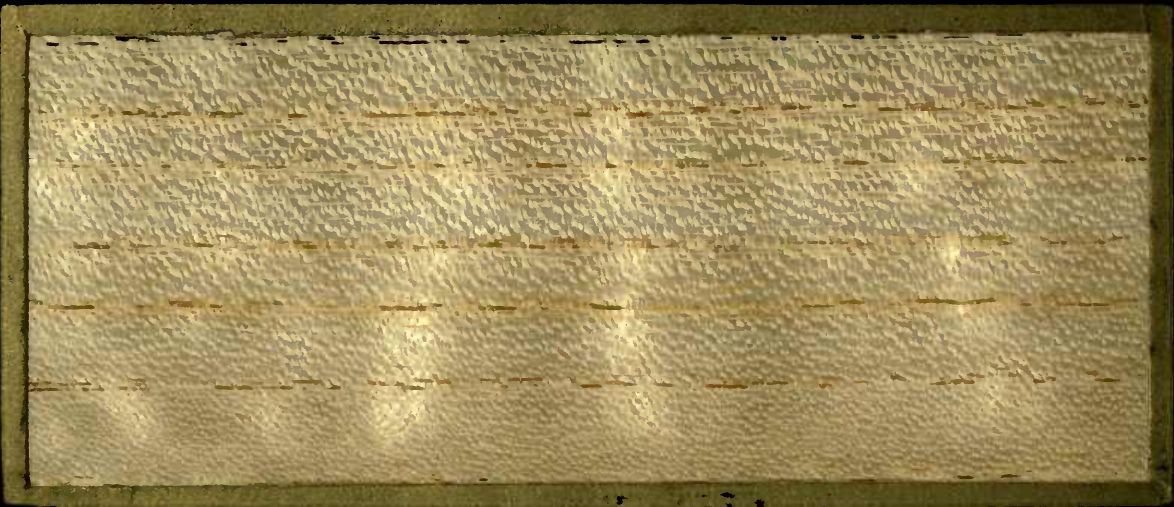

BADIAL BETIOH.

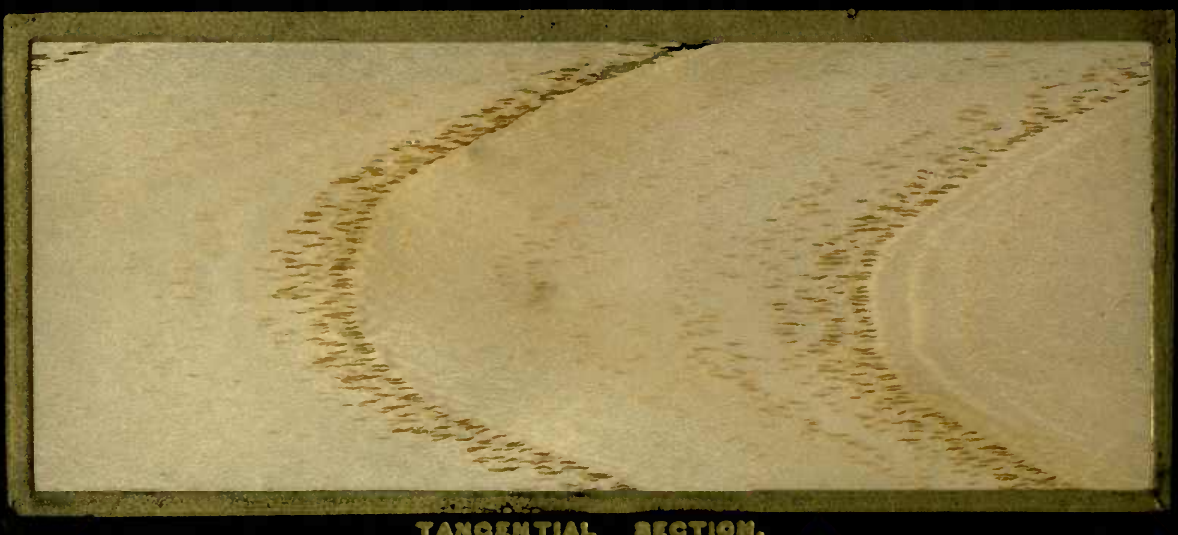

Ger. Drüsiger Gösterbaum. Sp. Barniz falso de Japan. T\%? Aylante glaudulenx. 


\section{RHUS TYPHINA, L.}

Sumach, Stag-horn Sumach, Virginian Sumach.

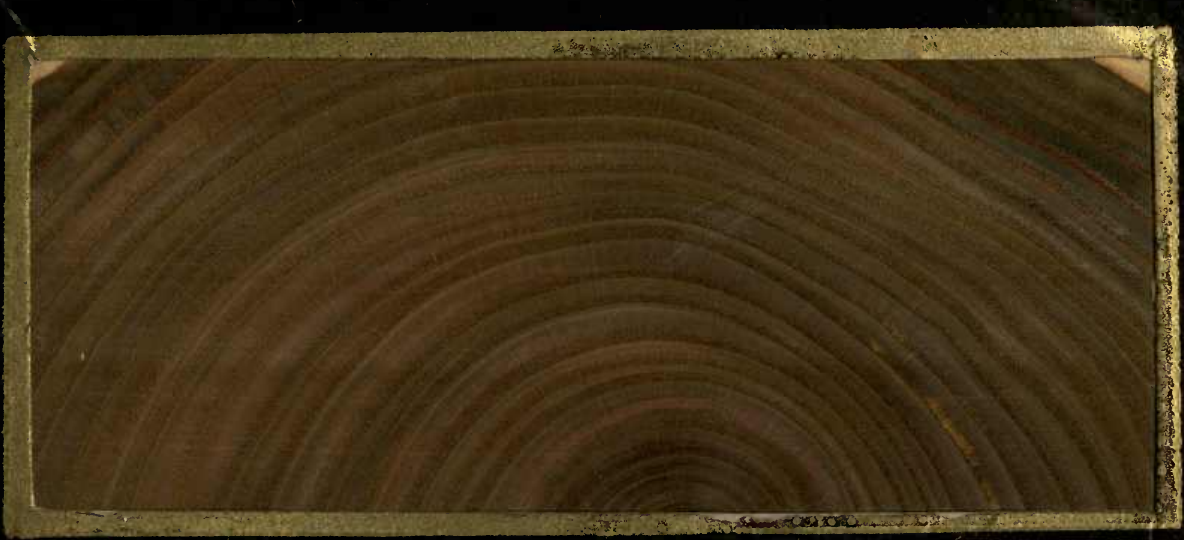

THAWGVERE : 8EQTIOH:
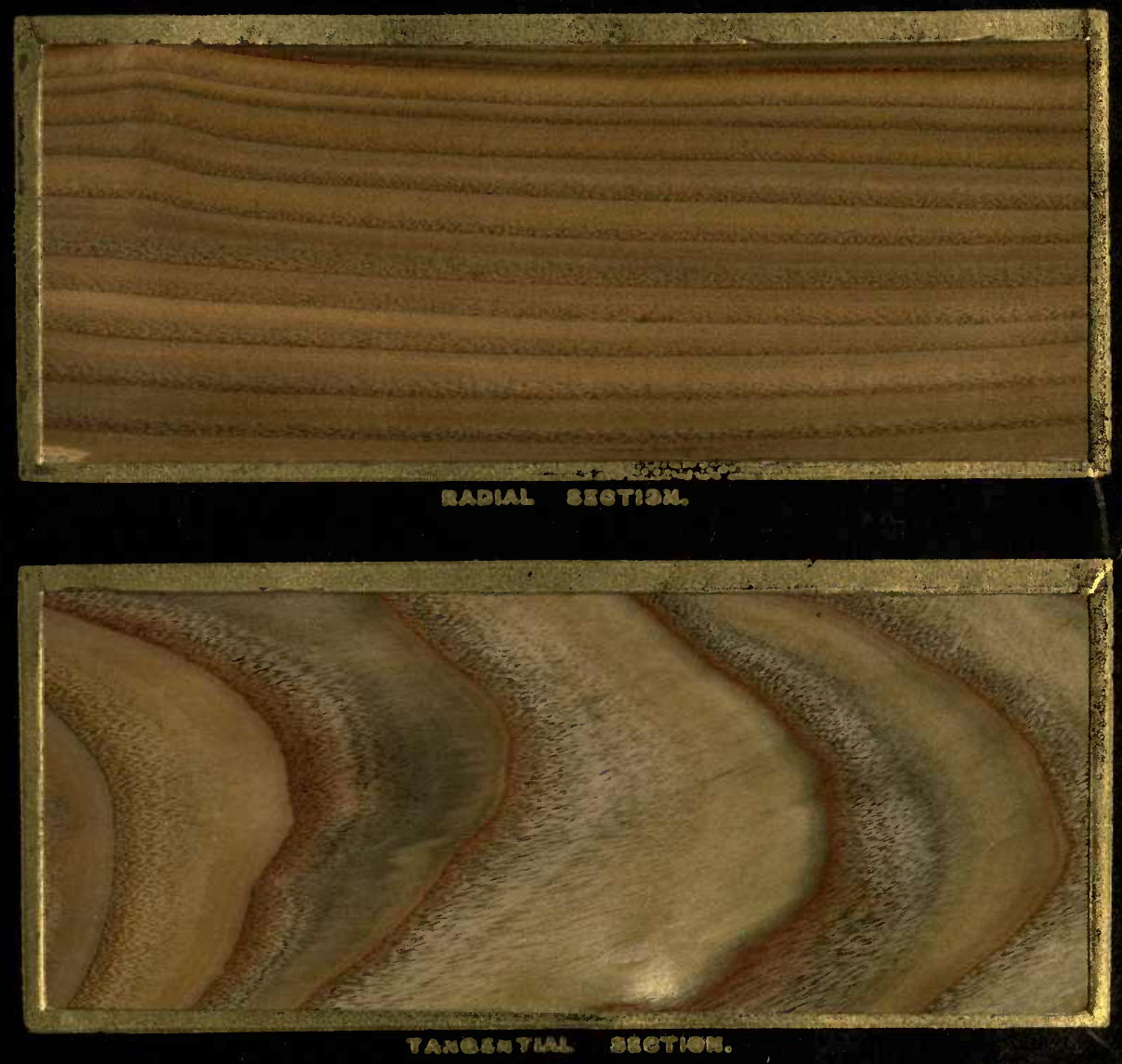

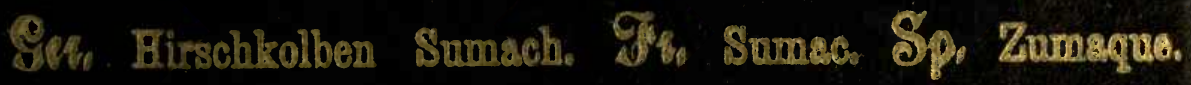

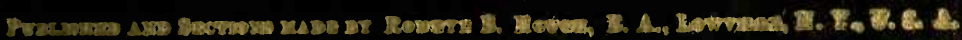




\section{RHUS TYPHINA, L.}

\section{Sumach, Stag-horn Sumach, Virginian Sumach.}

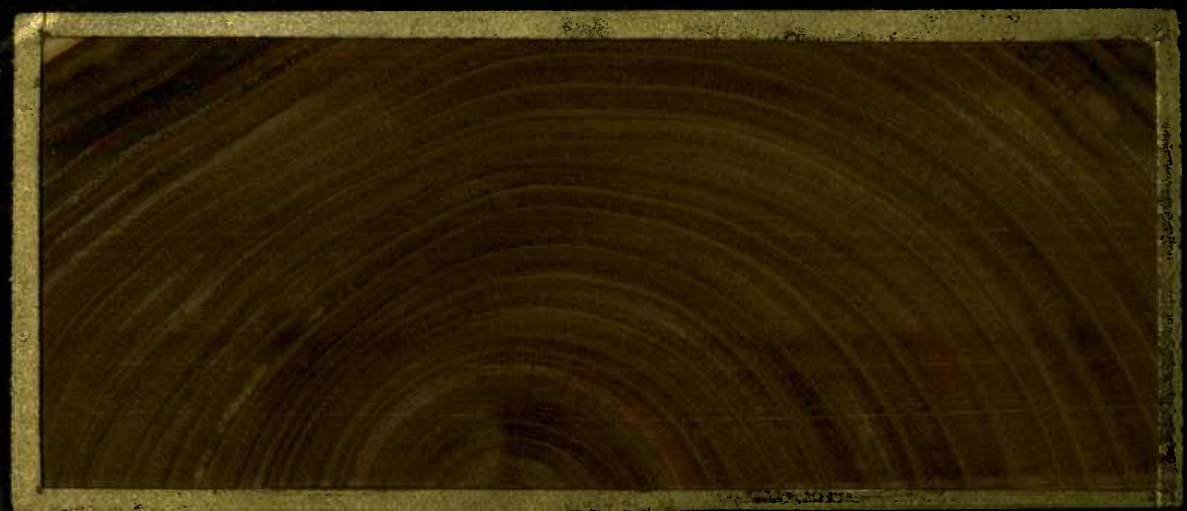

TRAMBVERSE BRETIOH.

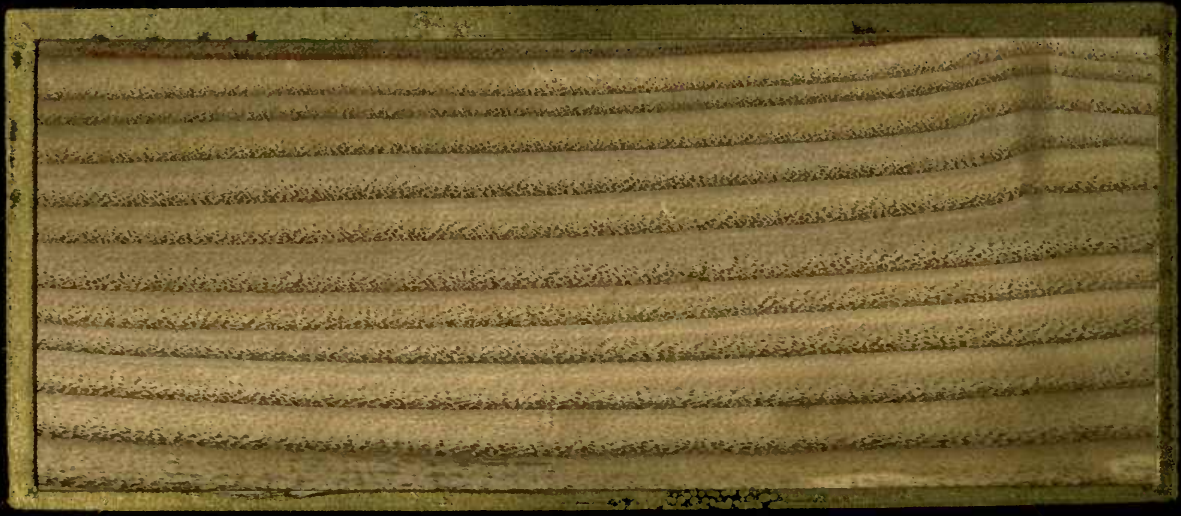

DabLas setrom

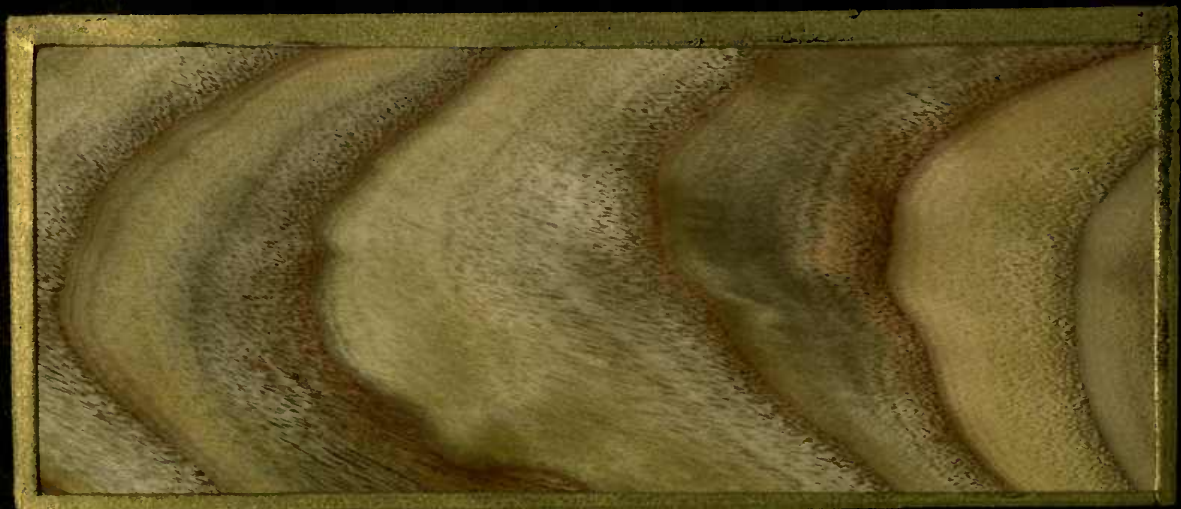

Tanosarms eseriot.

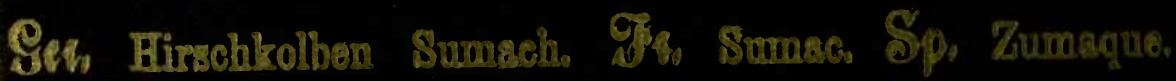


6. AESCULUS HIPPOCASTANUM, L.

Horse Chestnut.

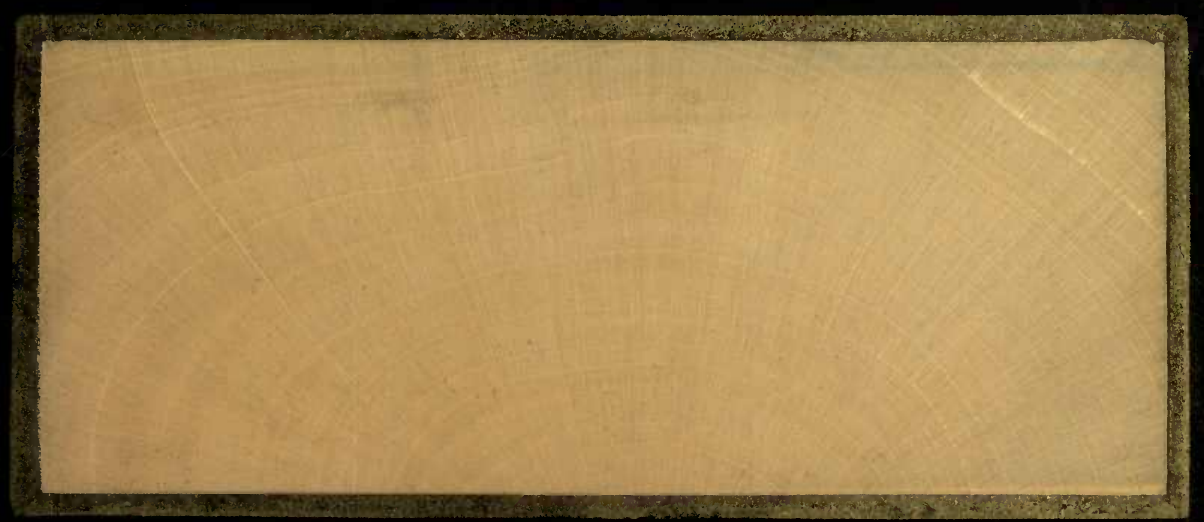

TRANSVERSE SECTION.

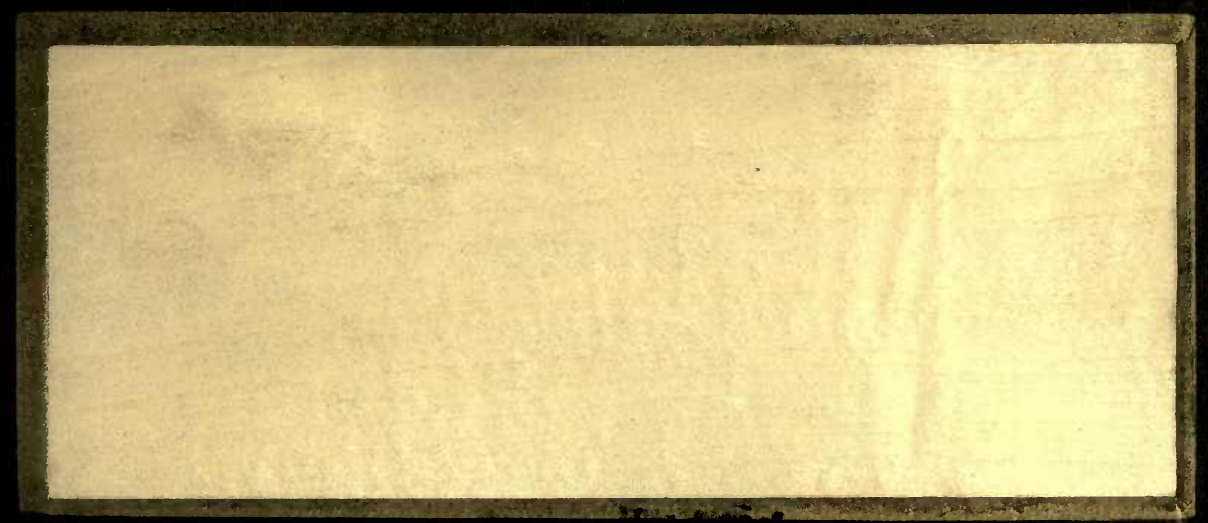

RADIAL SECTION,

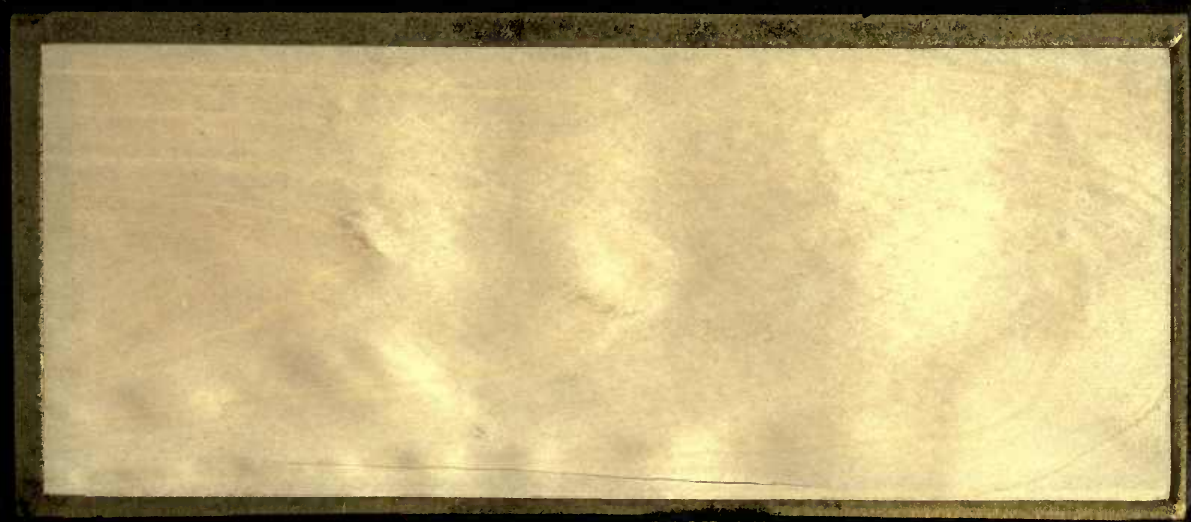

TANGENTIAL SECTION.

Ser Roszkastanie, Sp. Castaño de caballo. Th. Marronier d'Inde. 
6. AESCULUS HIPPOCASTANUM, L.

\section{Horse Chestnut.}

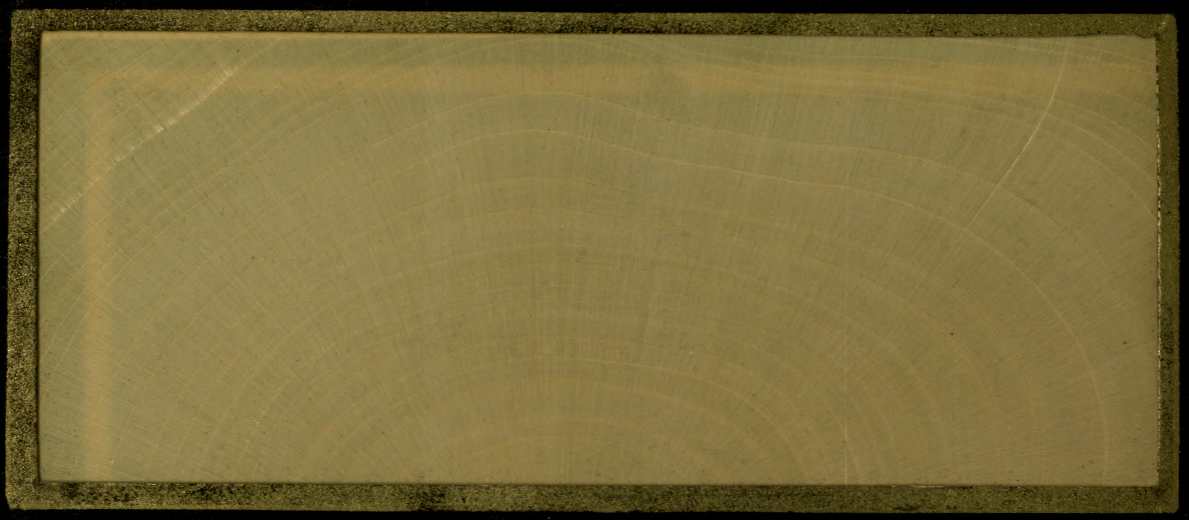

TRANSVERSE SECTHON.

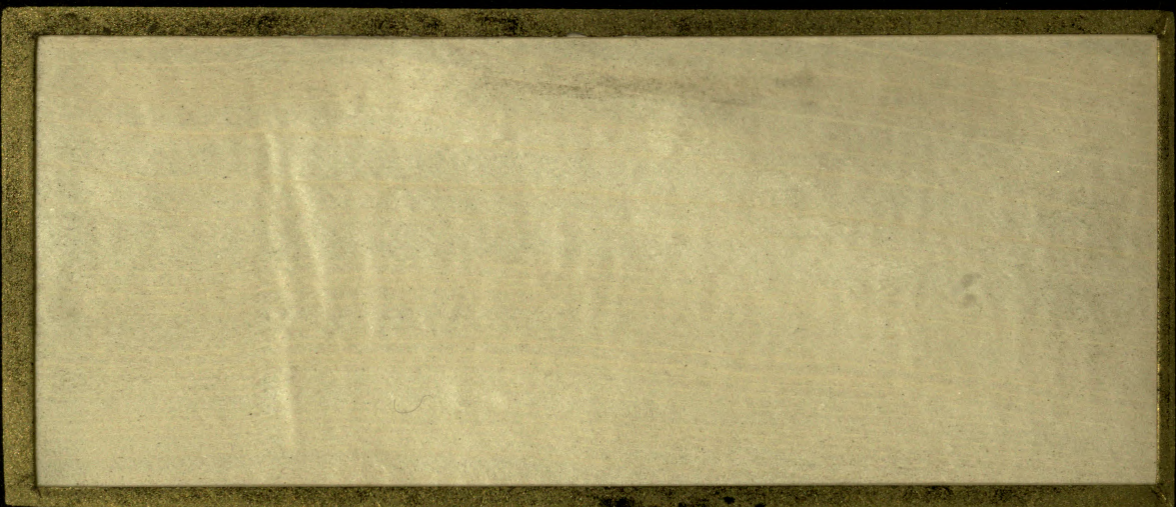

TANGENTIAL SECTION.

Ser, Roszkastanie. Sp. Castaño de caballo.

J', Marronier d'Inde.

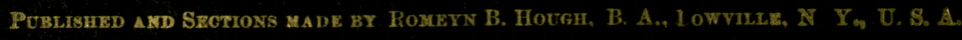


7. ACER SACCHARINUM, WANG.

Sugar Maple, Hard Maple, Rock Maple, Sugar-Tree.

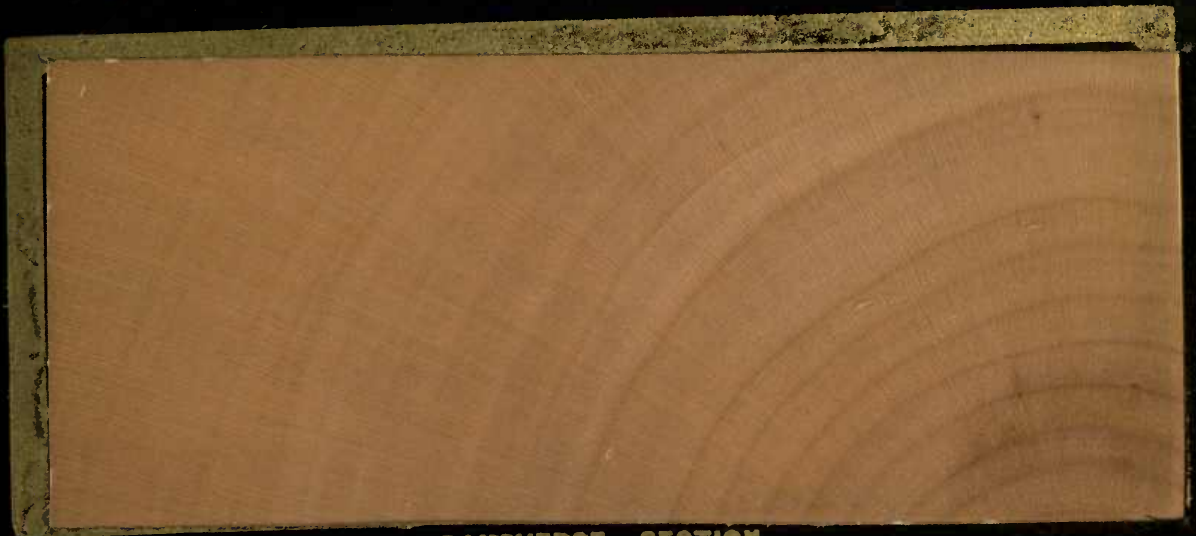

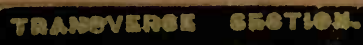

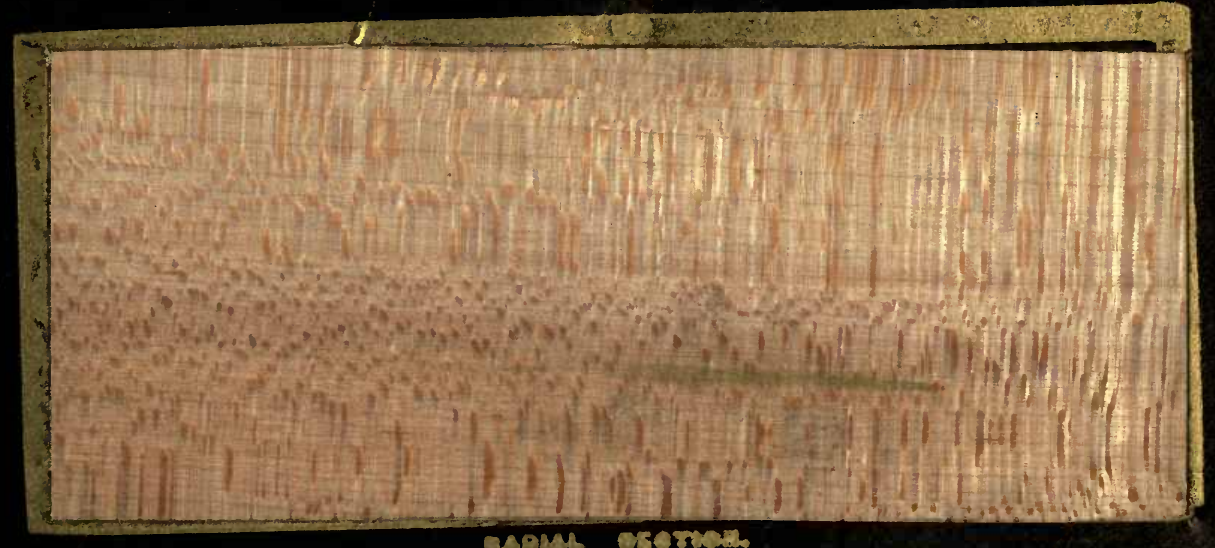

nover corsone

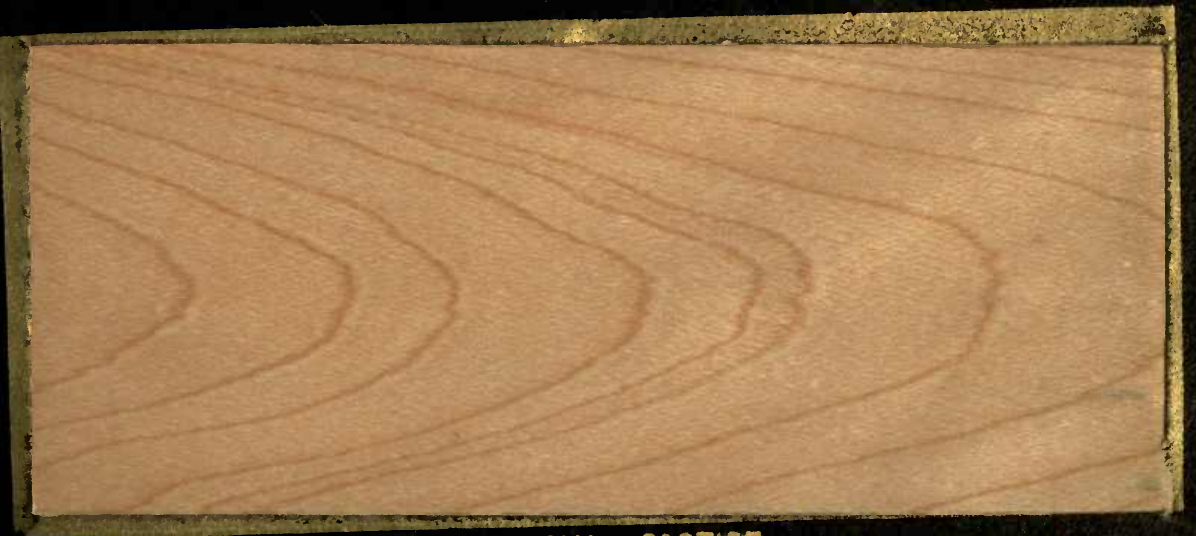

ranerotrab geothen.

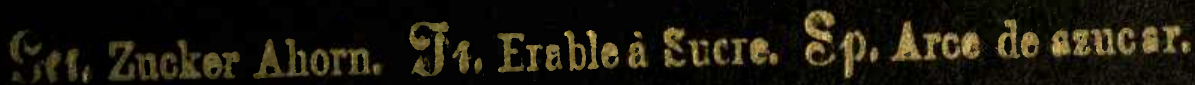


7. ACER SAGGHARINUM, WAMG.

Sugar Maple, Hard Maple, Rook Maplo, Sugar-Trea

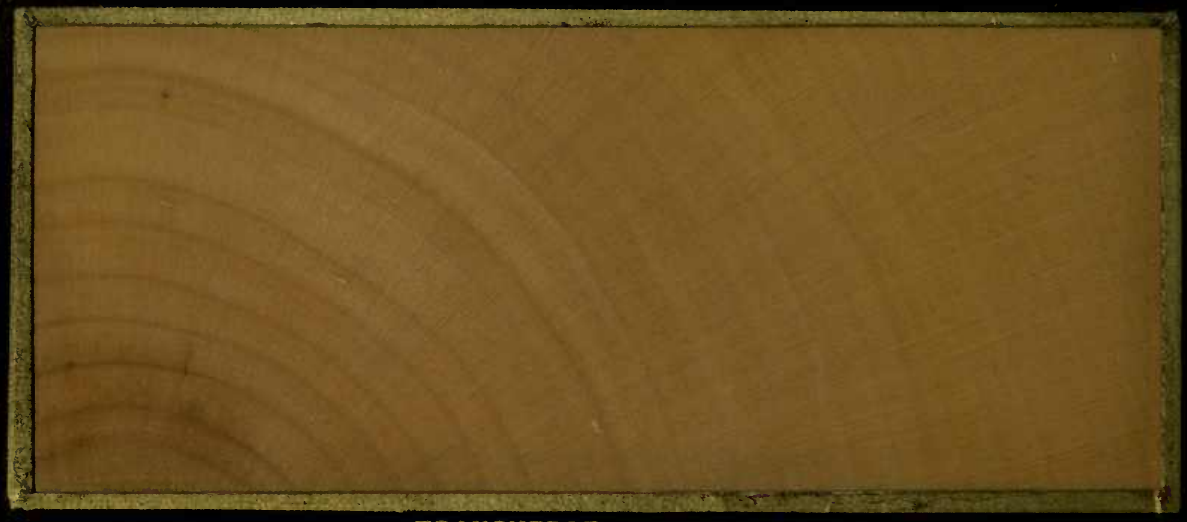

TRAMBVERER SEOTION.

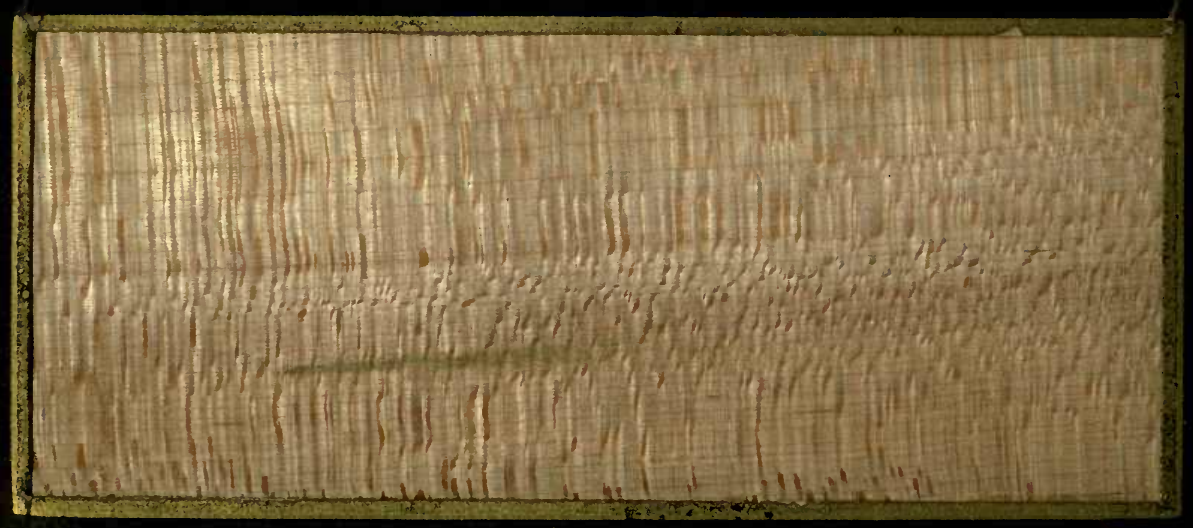

RABRAL OEOTIOL

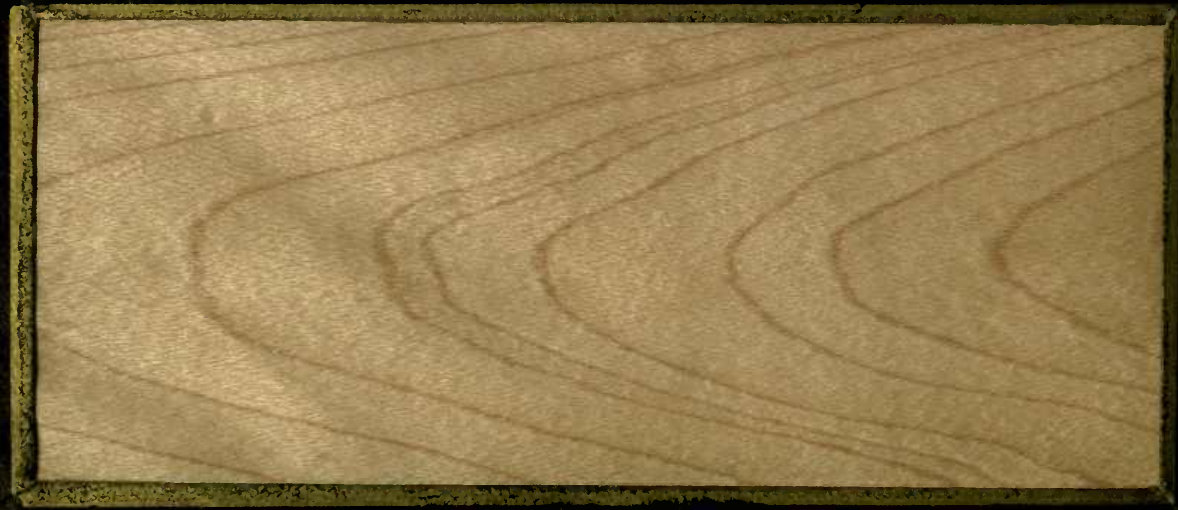

รAMOEMTIAL BECTION,

Ser, Zucker Ahorn, J̆J Erable à Sucre. Ep, Arce de asucar. 
$7^{a}$. ACER SACCHAFINUM, WANG.

Sugar Maple-Blister Figure, Elister IFap’e, Landscape Maple.

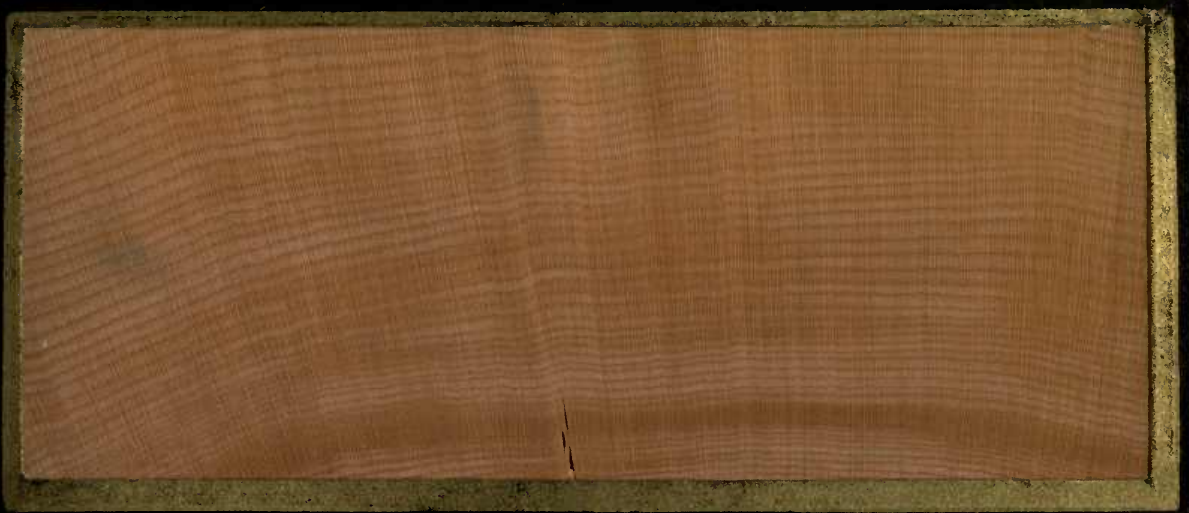

SEAREVEREZ SEGTIOU.

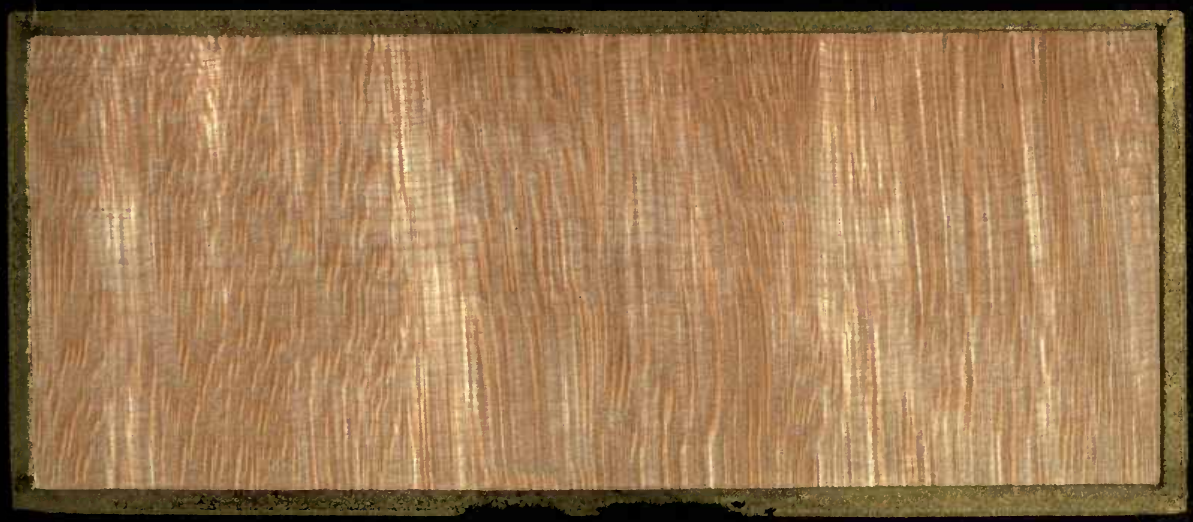

ansias agoviome

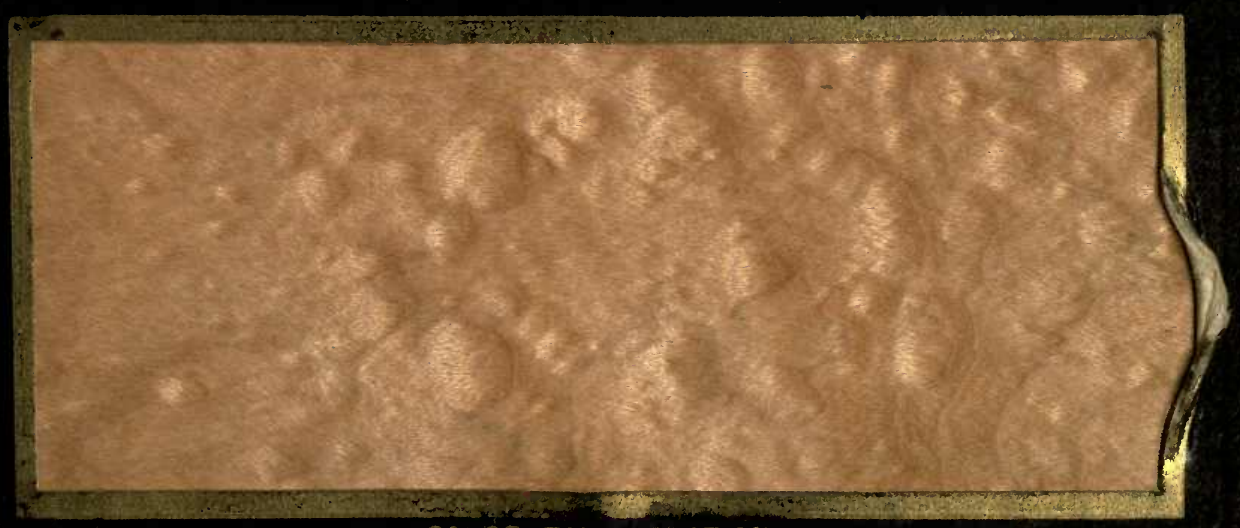

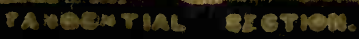

Sieq, Bläscien Ahorr.

Sip. Aree con ampollas.

This Erablo pisinlens. 
$7^{\circ}$. ACER SACCHARINUM, WANG.

Sugar Maple-Blister Figure, Blister Maple, Landseape Maple,

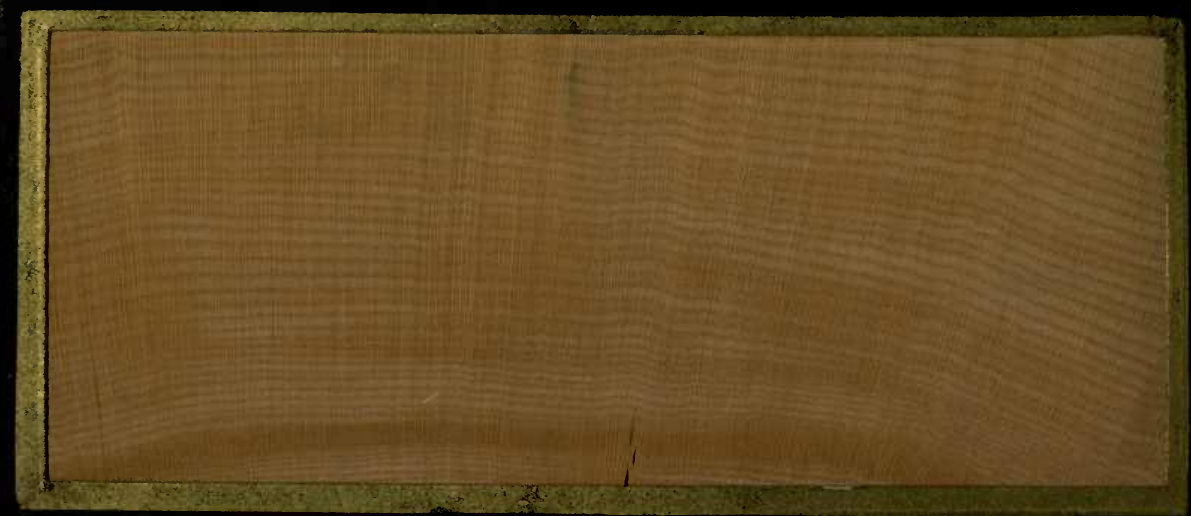

IรAMSVERTE SETTIN.

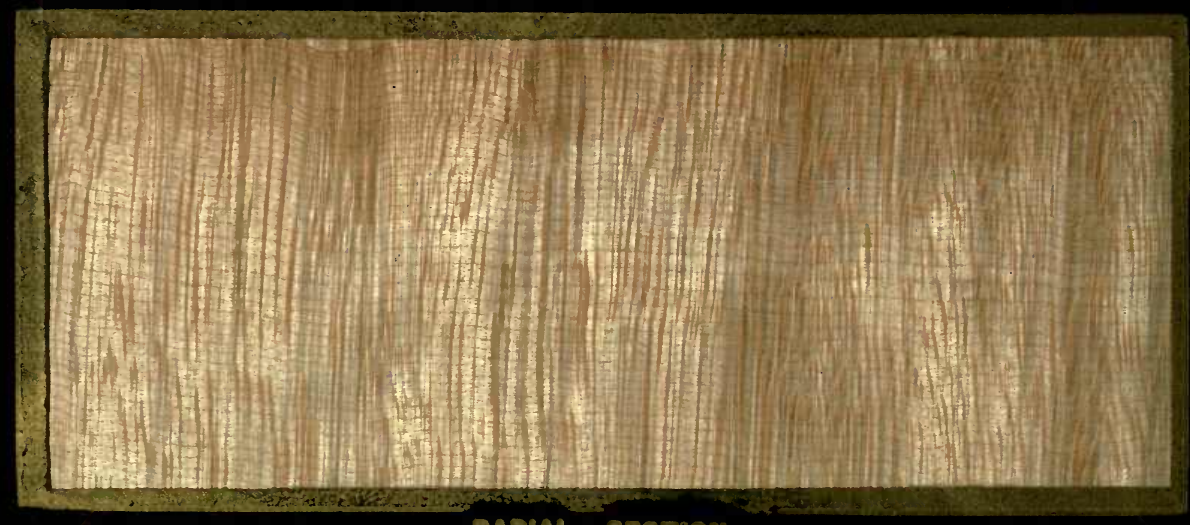

Dablal Bgorgom

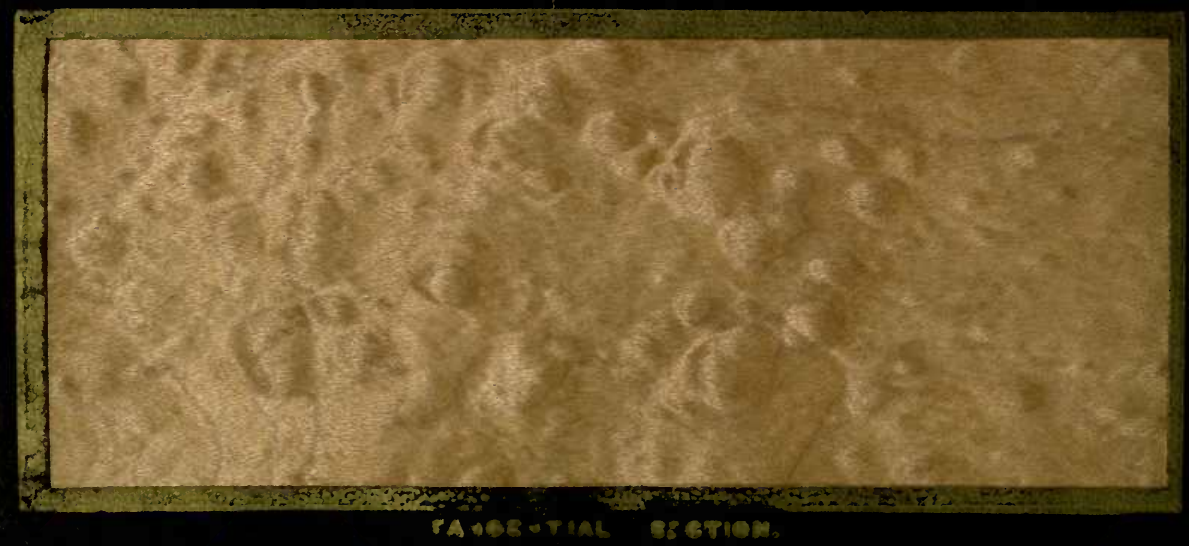

Ser, Bläscín Ahor\% Sigr, Aroe con ampollas,

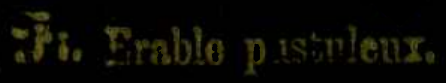




\section{ACER SACCHARINUM, WANC.}

Sugar Maplo-Birds-oyo Figure, Birds-eye Maple, Tin Maple.

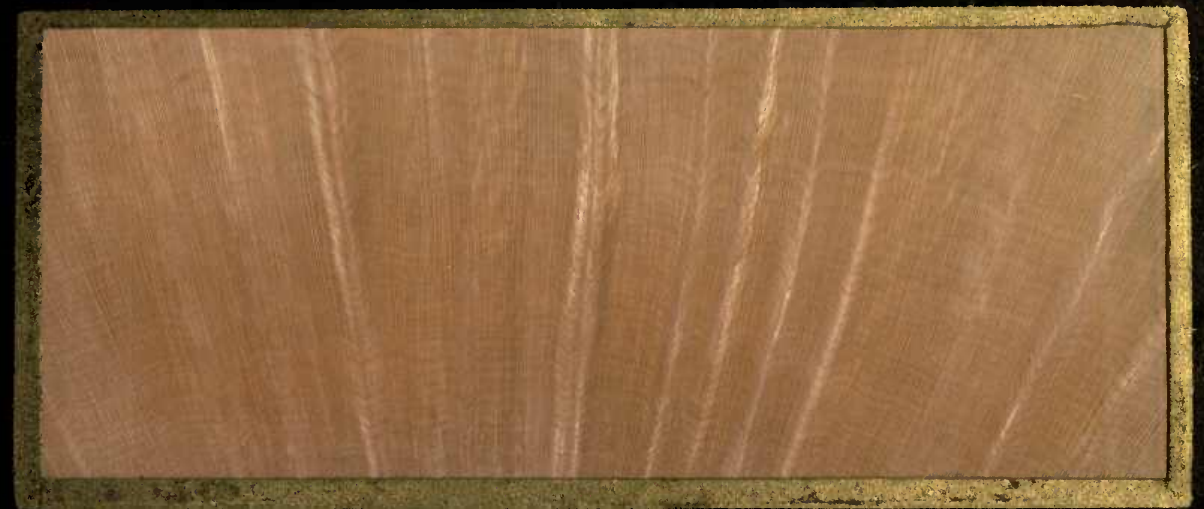

TRANBVEROE SEOTION.

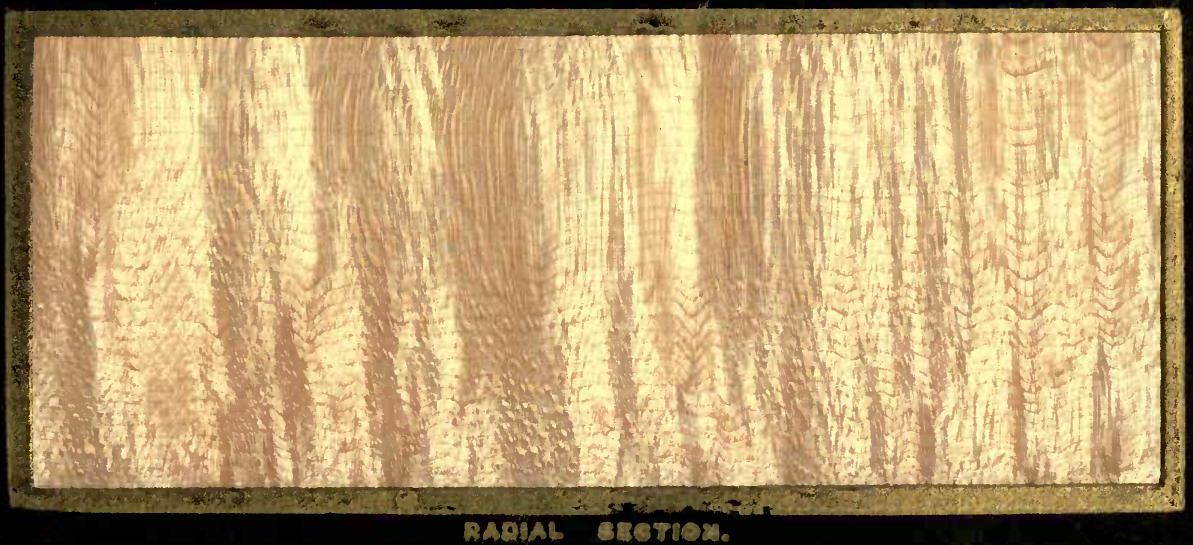

BACIAB BEOTOE.

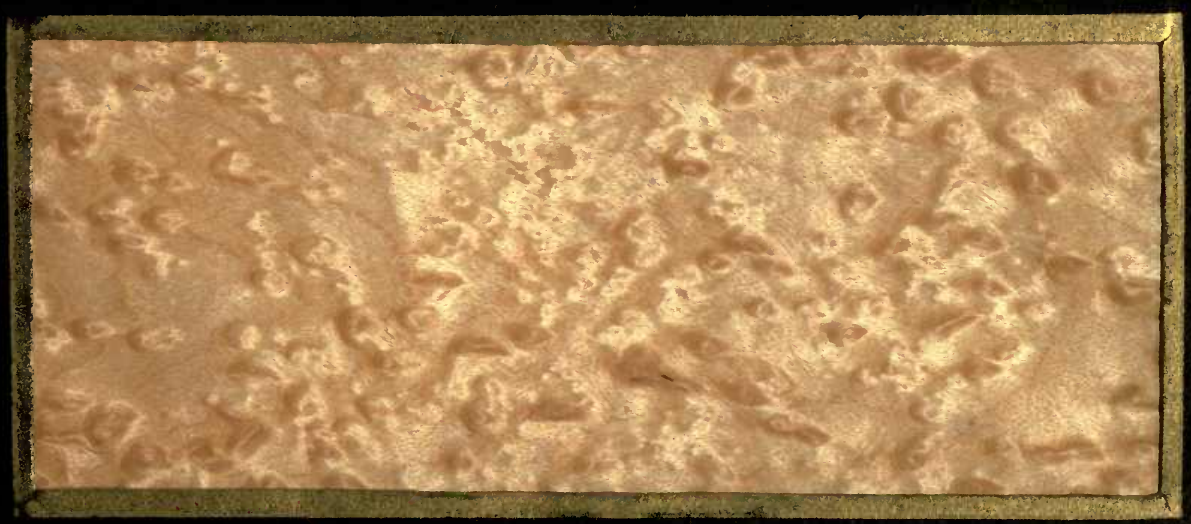

TANOENTHE czopion.

Sier, Augen Ahorn. - A. Arco ojo de pararo.

9. Erable oeil d'oiscesu. 


\section{7b. ACER SACCHARINUM, WANG.}

Sugar Maple-Birds-oye Figure, Birds-oye Maple, Pin Maple,

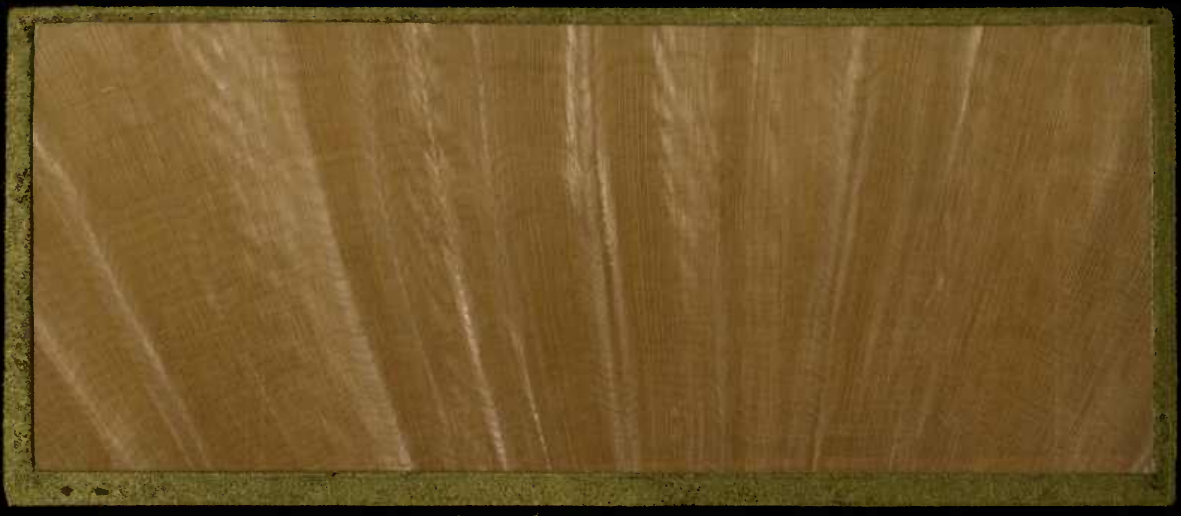

TRAMOVERSE SECTION,

RADIAL BETTOM.

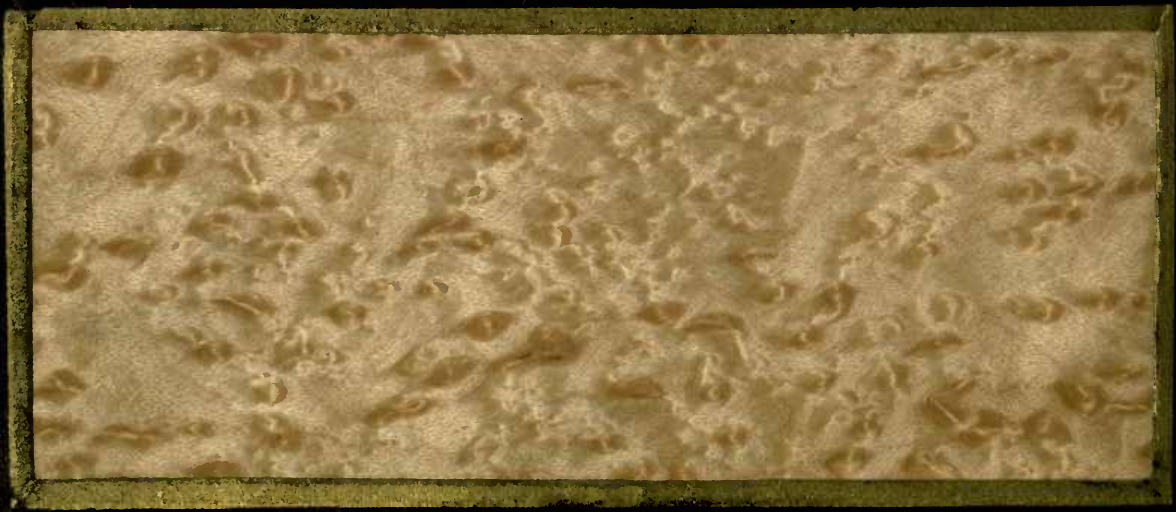

TANOBNThL Sorion.

Ser, Augen Ahorn. s., Arge ojo de pasaro.

\$1. Erable ocil d'oiseasu. 


\section{Heroules' Clab, Angelica-Tree, Toothache-Tree.}

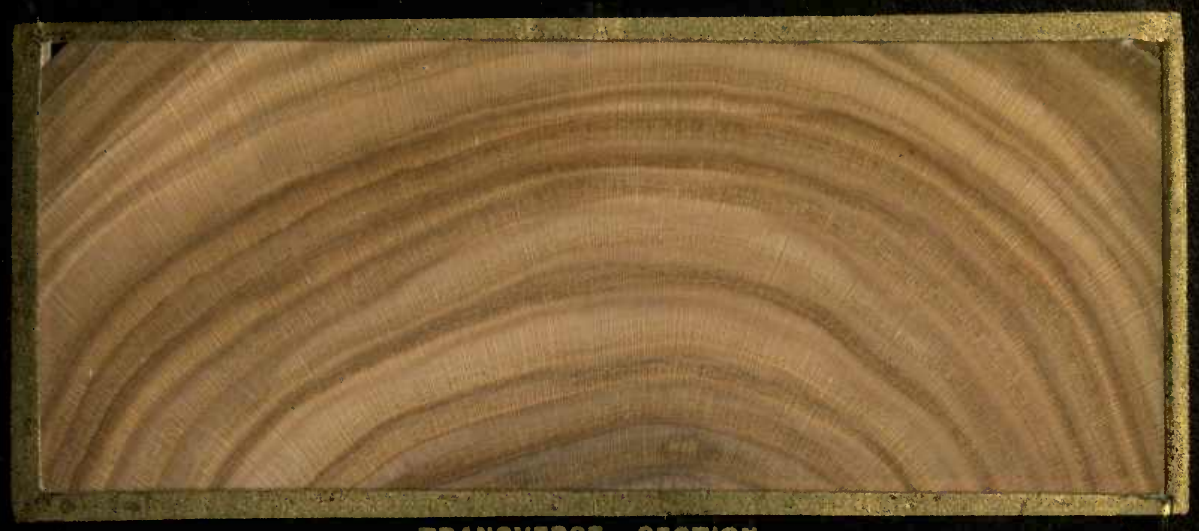

\section{TRAMSVERSE SECTIOW.}

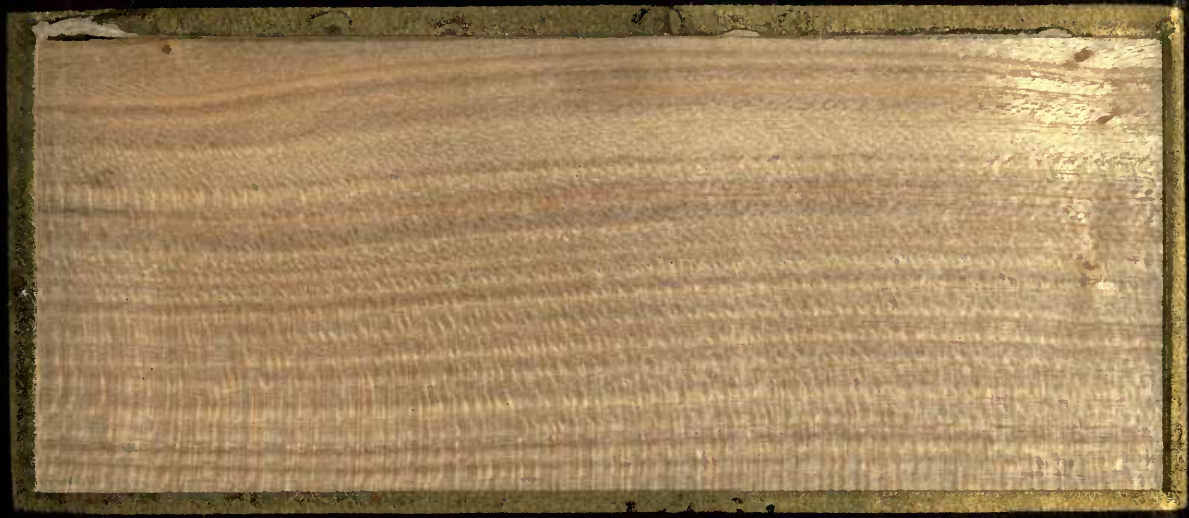

\section{RADIAL SECTION.}

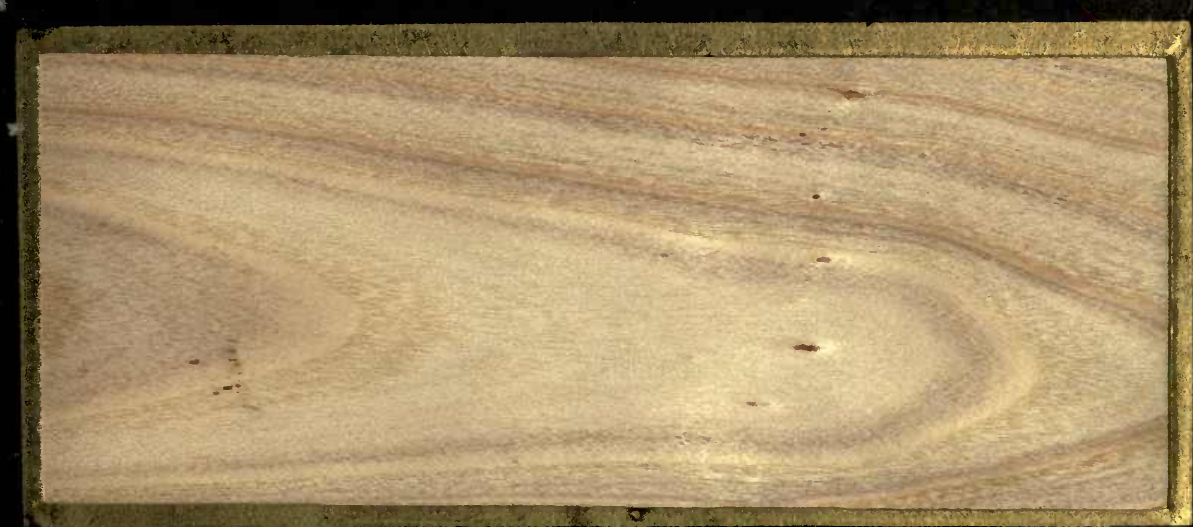

TANQ: TIAL EFCEION.

Ser. Dornige Bergangelike.

Sp. Aralia espinosa.

7\%. Aralia éspineuse. 
Hercules' Club, Angalica-Tree, Toothache-Tree,

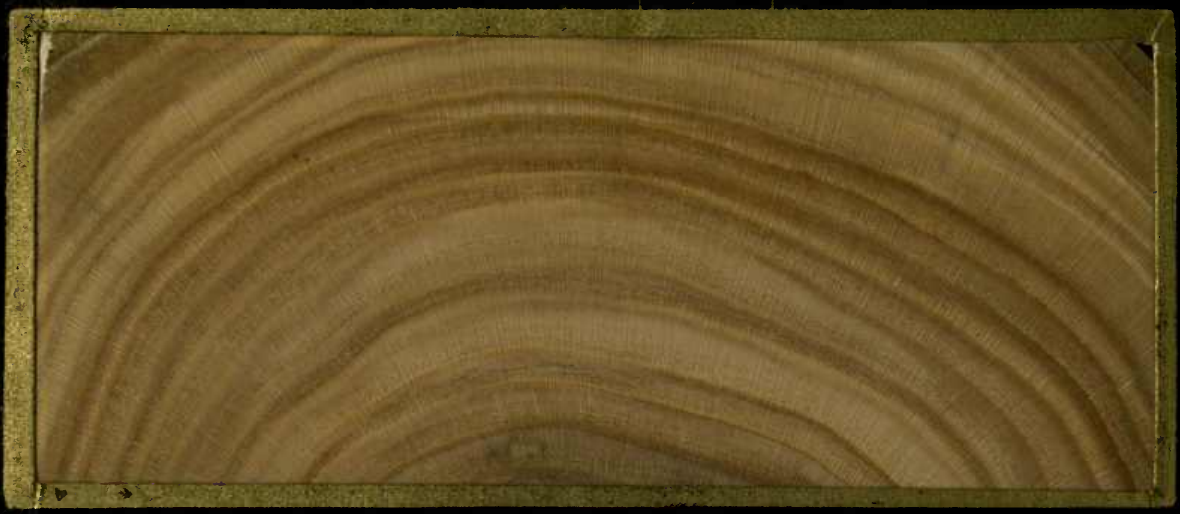

TRANBVERSE SECTIOW.

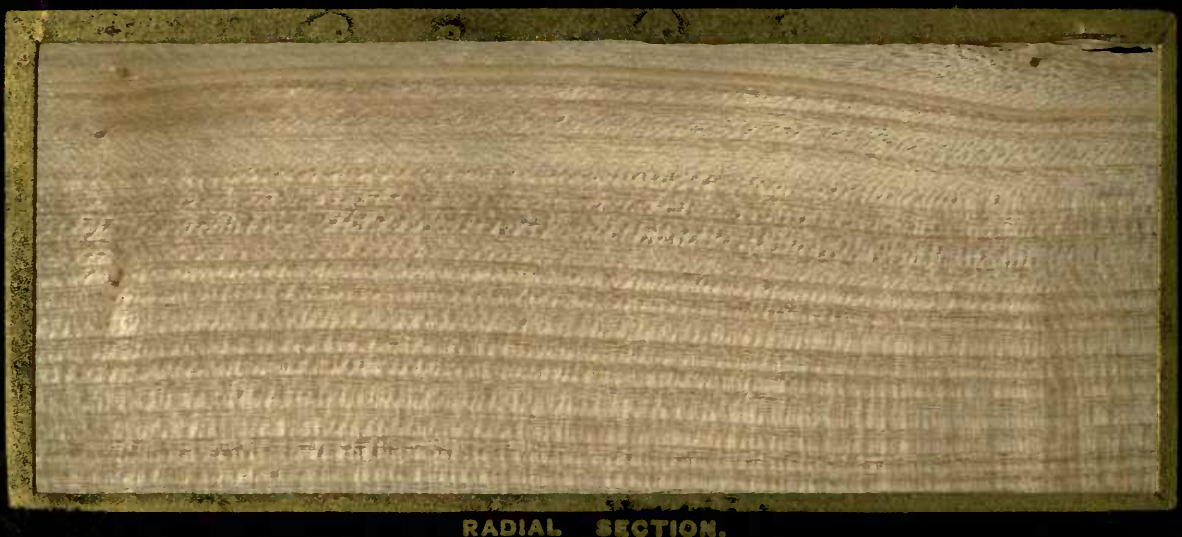

RADIAL SEOTION.

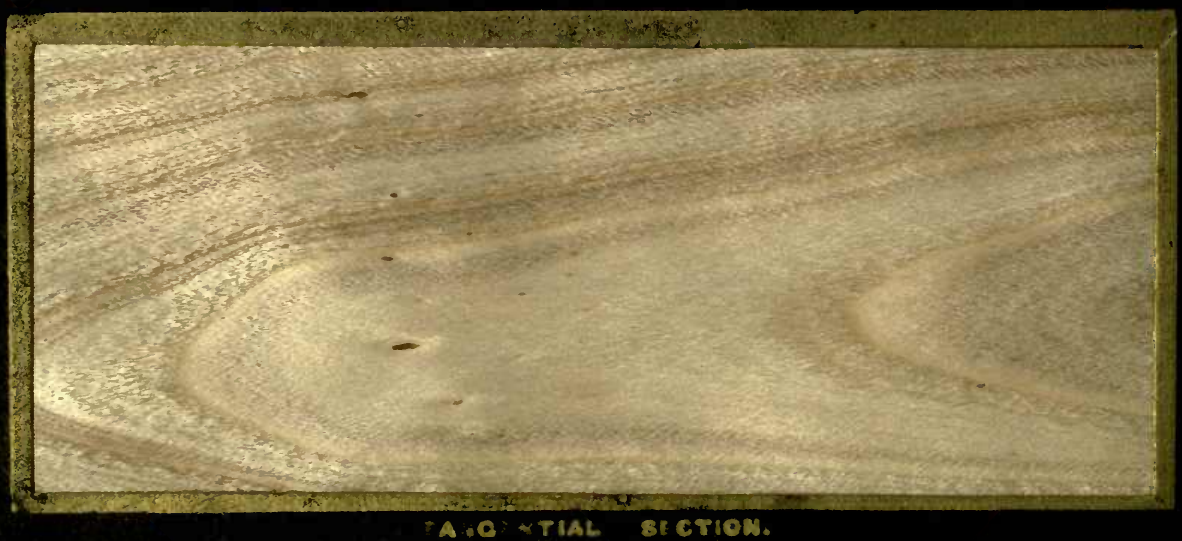

Ser. Dornige Bergangelike.

Apo, Aralia espinosan

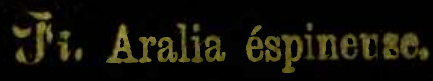


9. NYSSA MULTIFLORA, WANG. Rupolo, Pepporidge, Black or Yellow Gum, Sowr Gum.

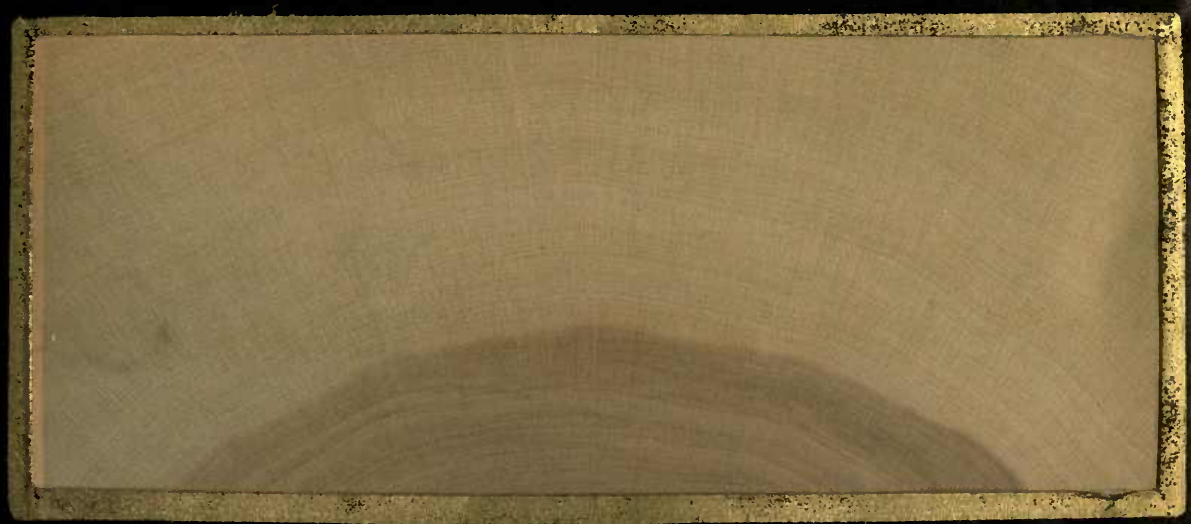

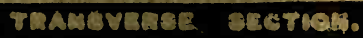

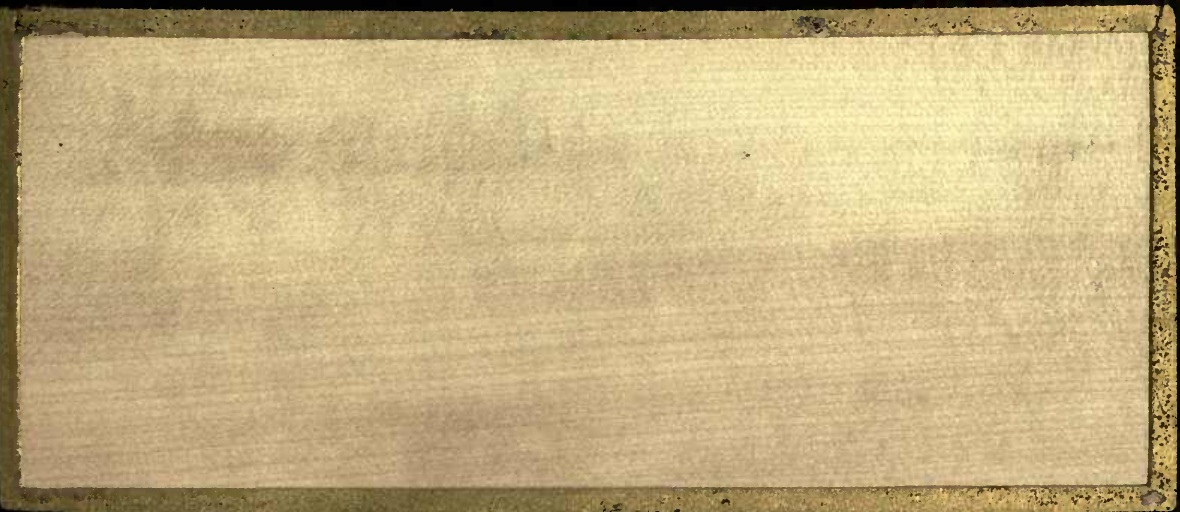

cabear cherion.

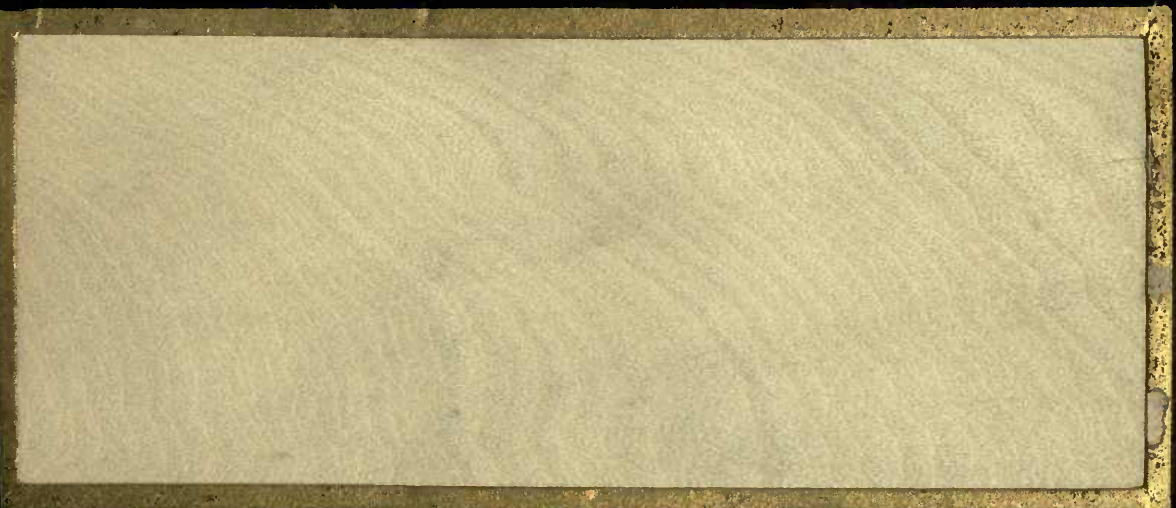

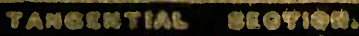

Qen, Sauer Gummibaum.

Spo Tupolo.

Ti: Gommier multifore. 


\section{NYSSA MULTIFLORA, WANG.}

Tupelo, Pepperidge, Black or Yollow Gum, Sour Gum.

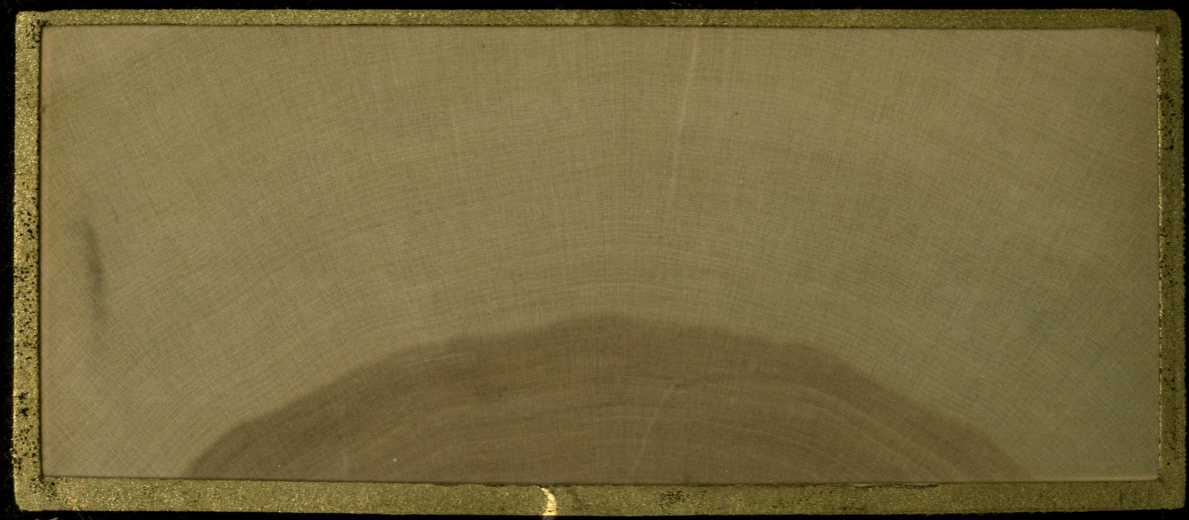

TRAMOVEROS BEGTHOH.

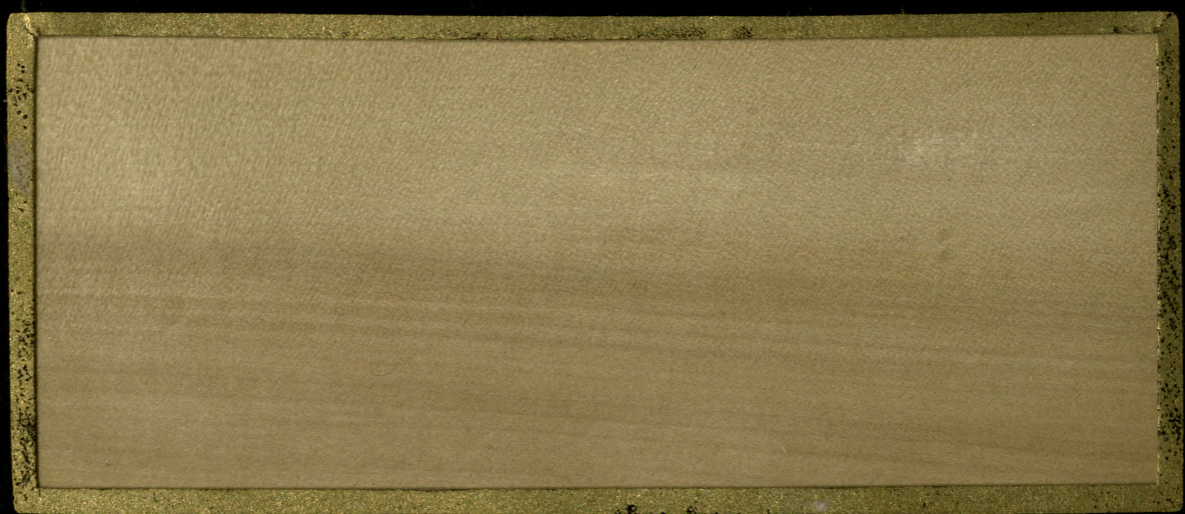

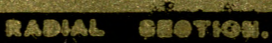

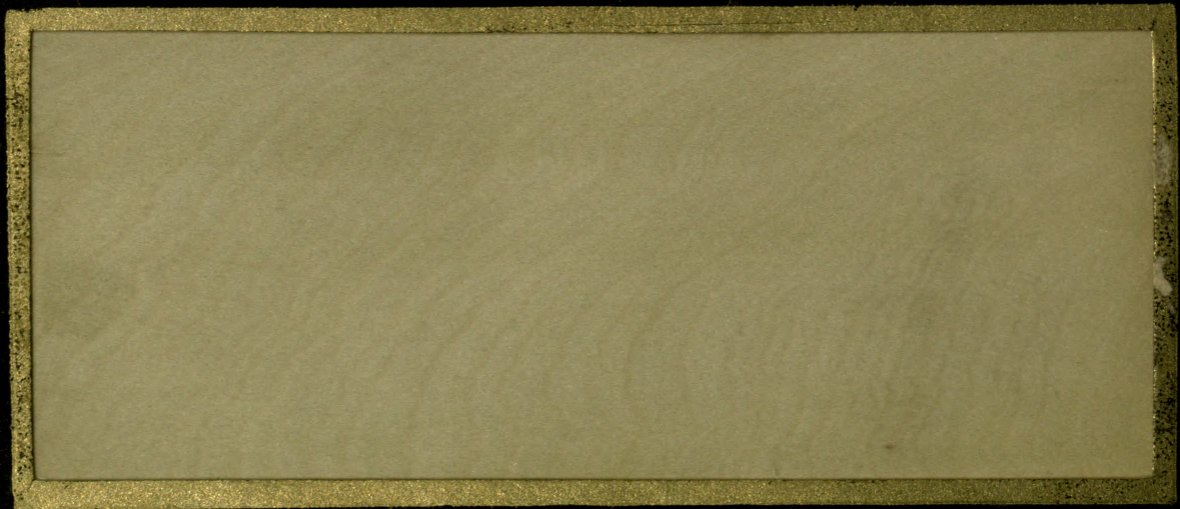

TAMESETIAB GEFHOA.

Seri Sauer Gummibaum. Sp. Tupole.

Tito Gommier multiflore. 


\section{FRAXINUS AMERICANA, L.}

\section{White Ash.}

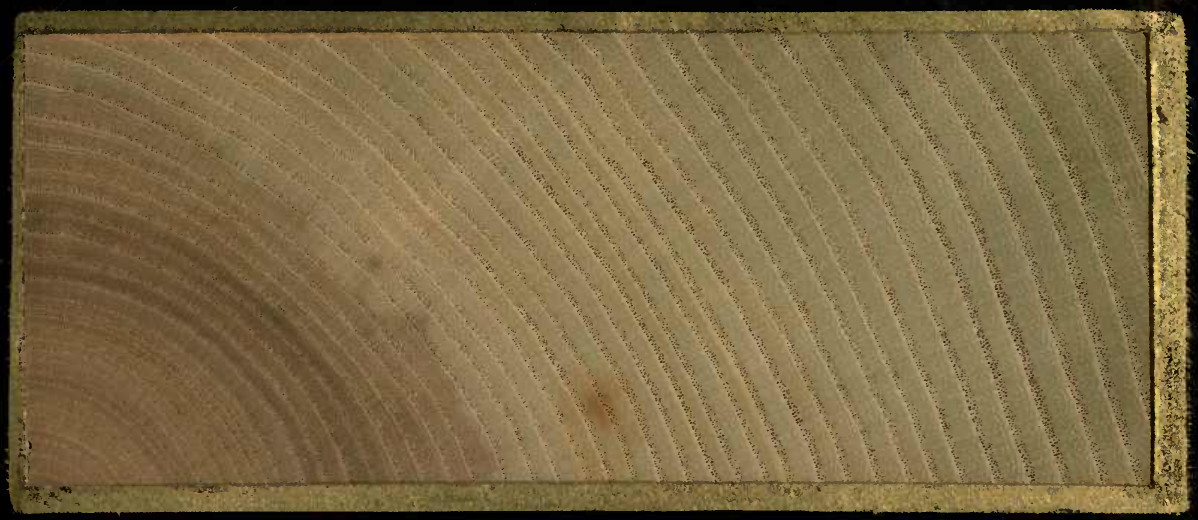

TAAMEVERSE SECTION.

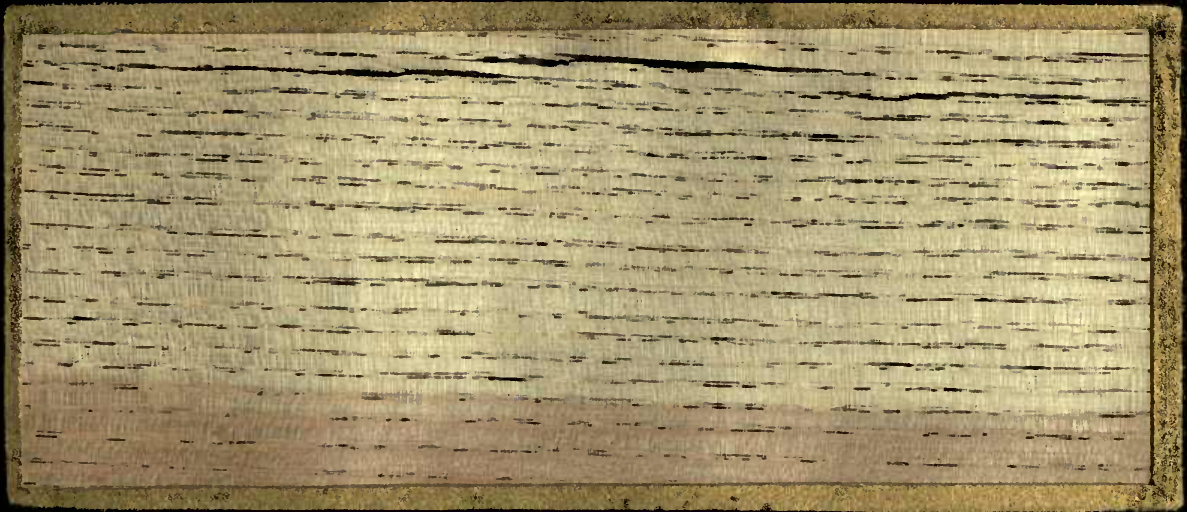

\section{RaDil sRetrom.}

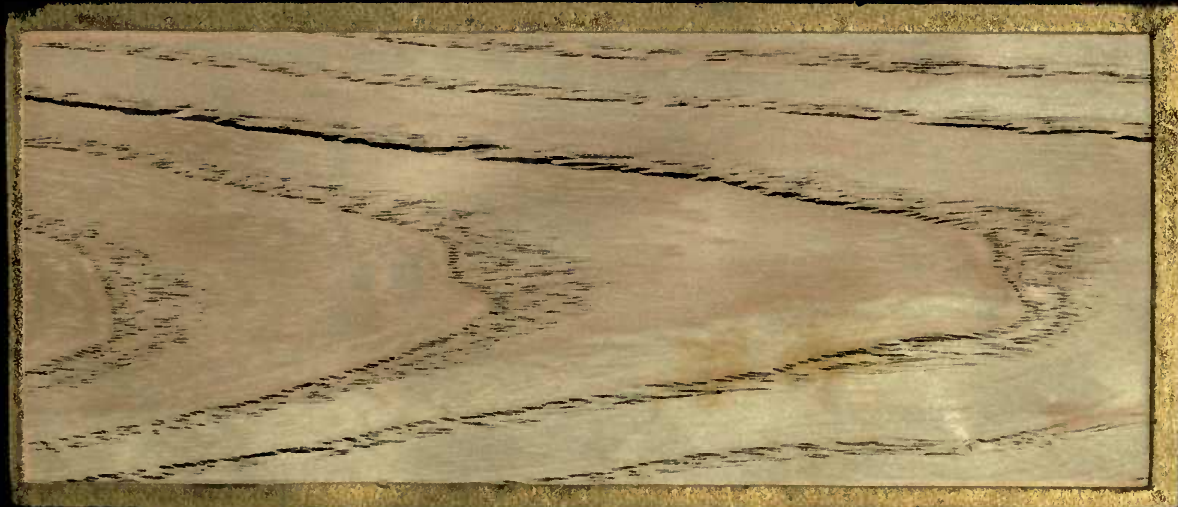

TANGENTIAL OEGTHOM.

Ger. Amorikanische Esche. SPpo Fresno Amerianno.

Tid 4 Frêne Amoricain. 


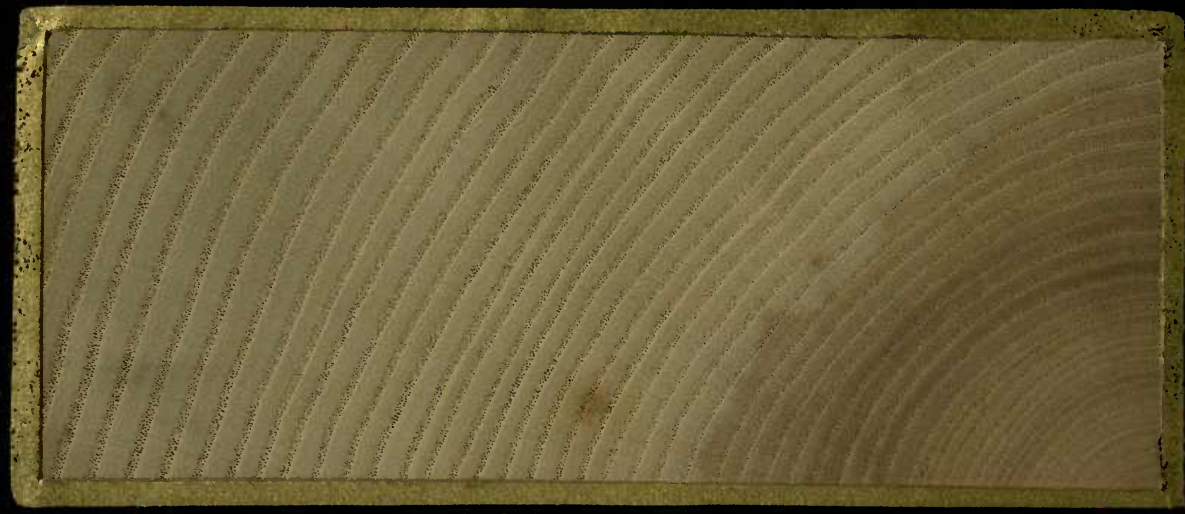

ThMovinar astron.

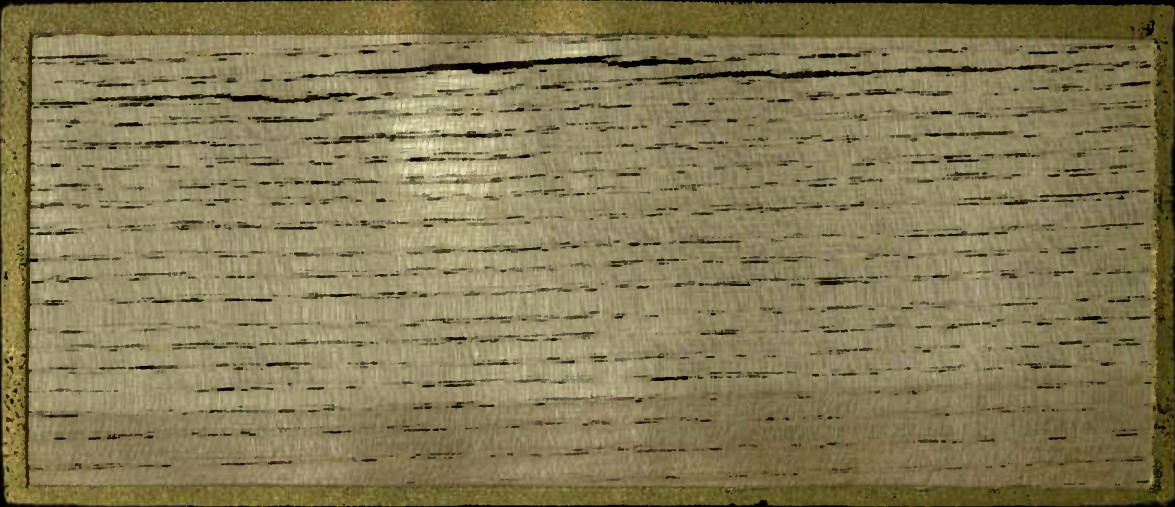

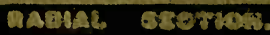

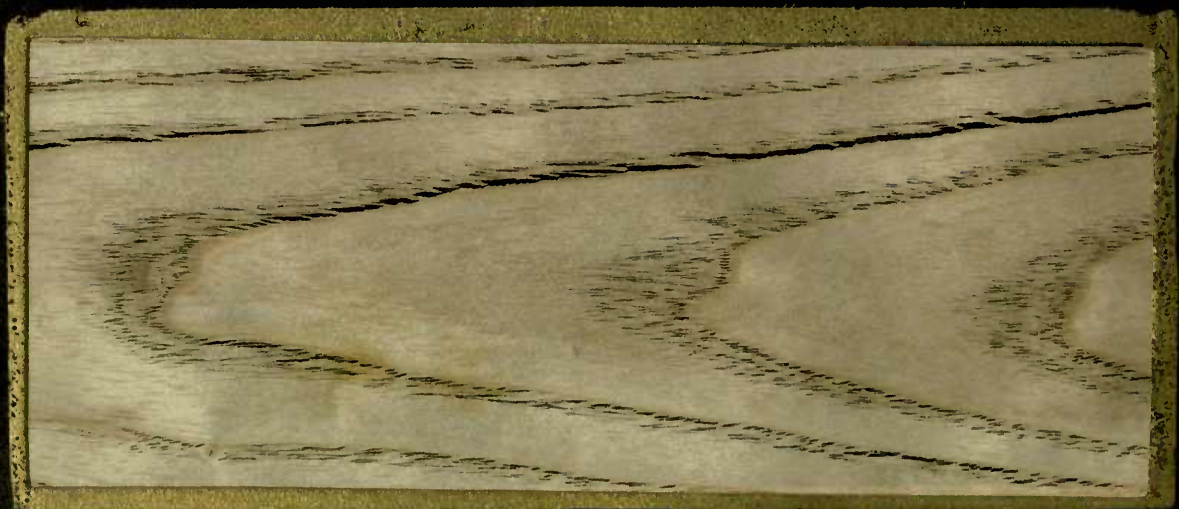

PAMGENTIAL SFOTHON.

Ben, Amorikanische Ische.

ăp. Fresno Amoriongo.

Give Frêne Amoricsion. 


\section{ULMUS FULVA, MICH.}

\section{Slippory Elm, Red Elm, Moose Elm.}

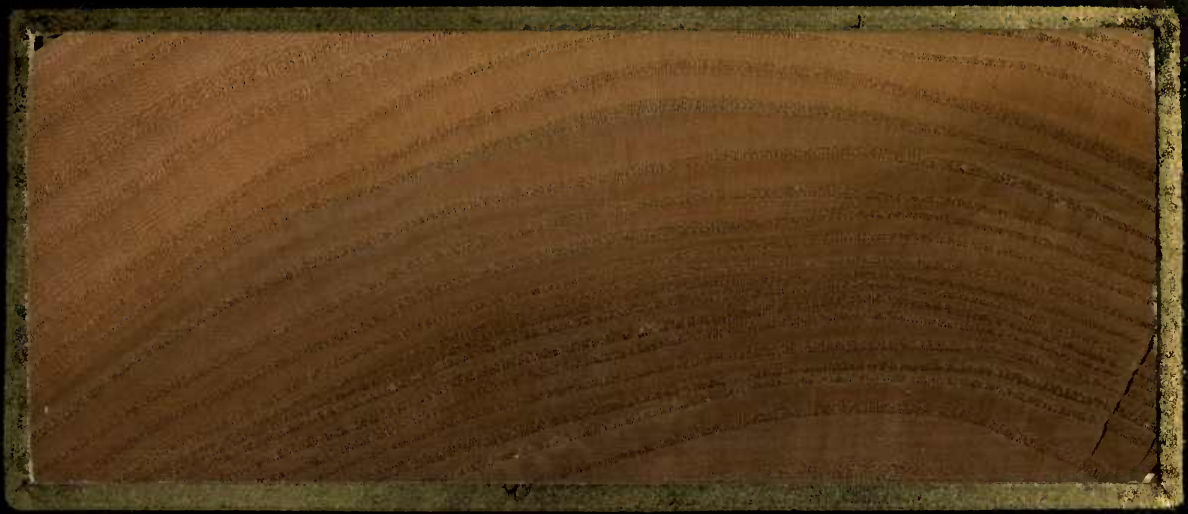

THANBVBas BSG

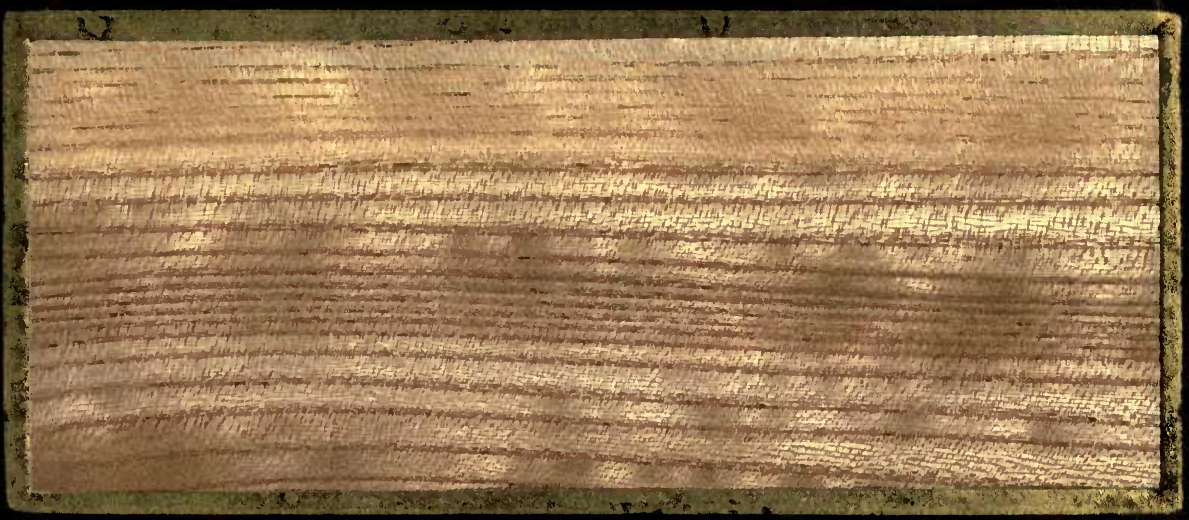
RADLAL SEOTIOU

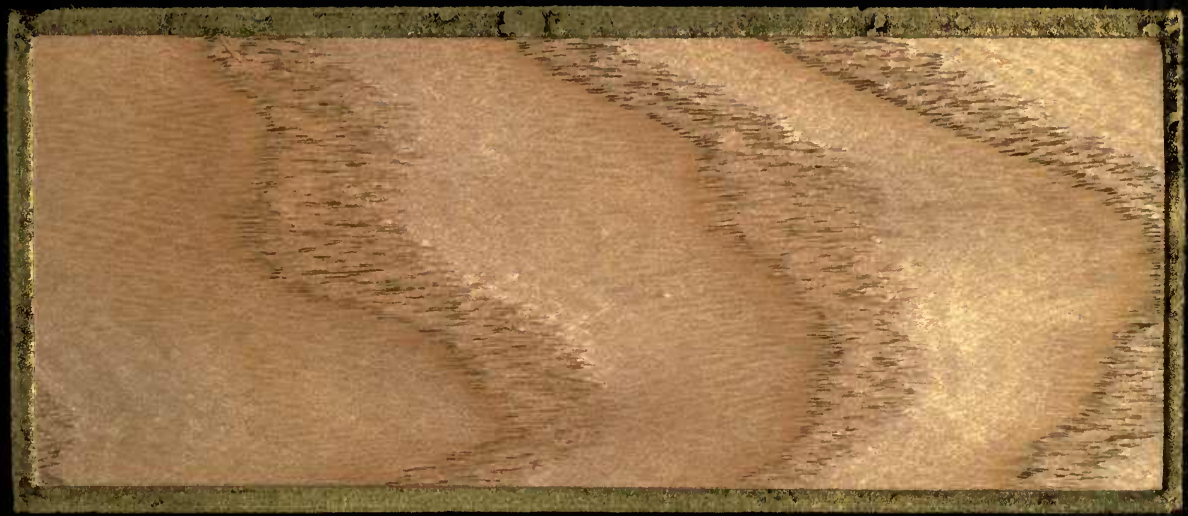

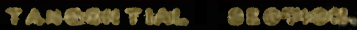

Sirto Rothe Ulme. Spo. Olmo coloracico. 敢 Orme gras. 


\section{ULMUS FULVA, MICH.}

slipgory Fim, Red Elm, Moose Elm.

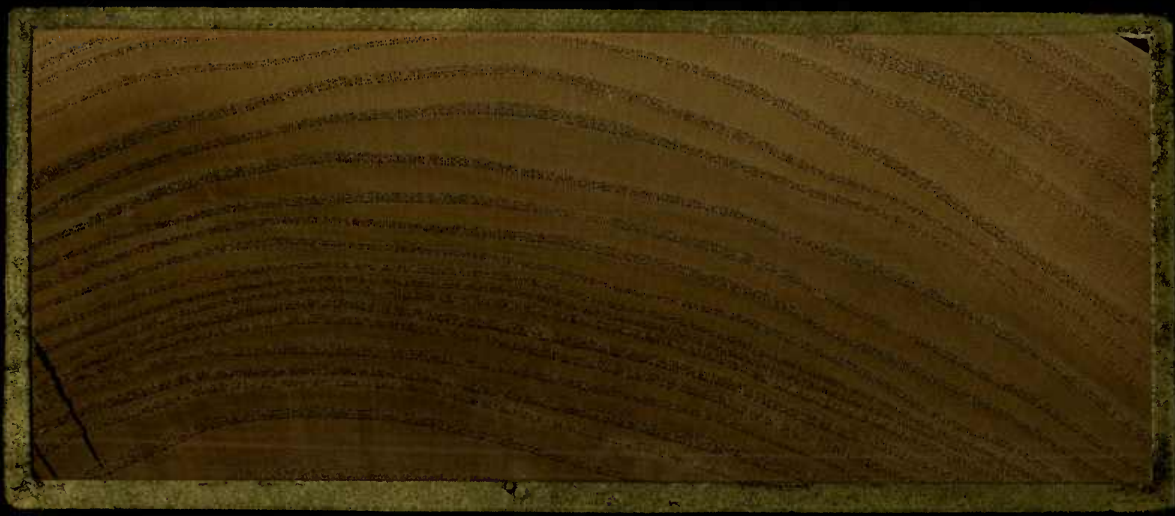

TRAMBVEGE BRETHOM.

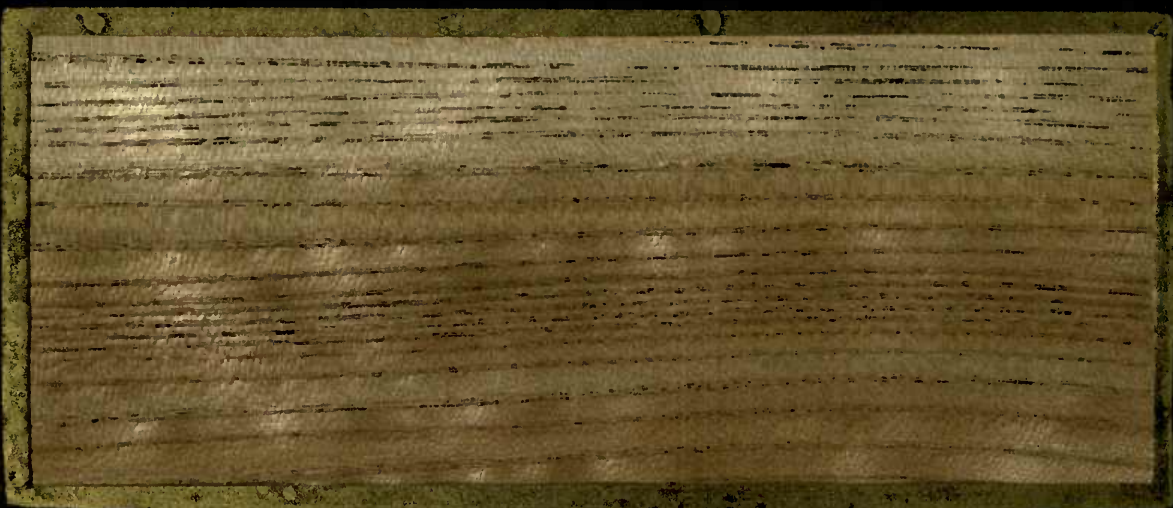

Raplas seotrous.

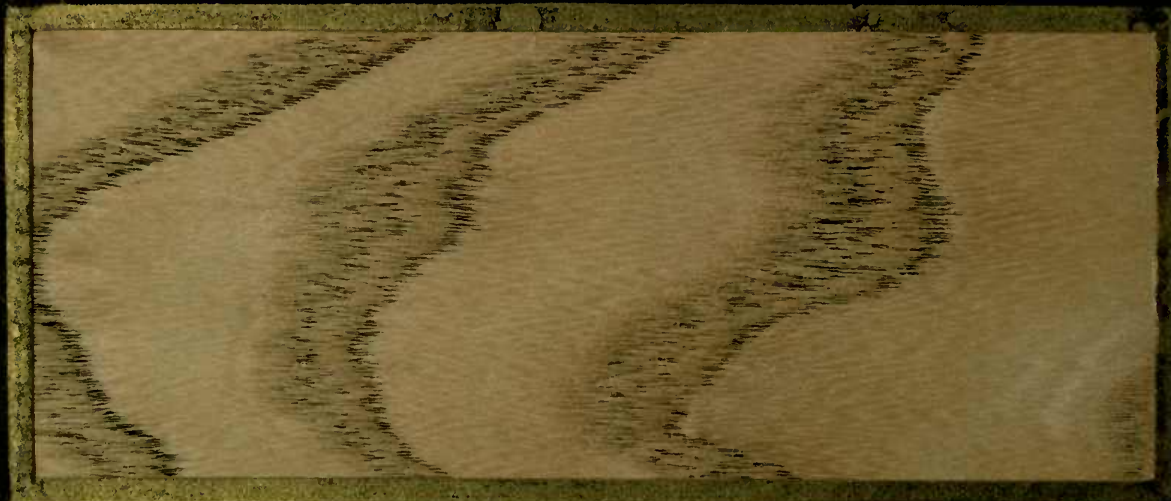

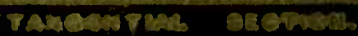

Sir, Rothe Ulme. Appo Olmo collor: ace.

雅, Orme gras. 


\section{CELTIS OCCIDENTALIS, L.}

Sugarberry, Hackberry, Nettle-Trec, Falno Flan.

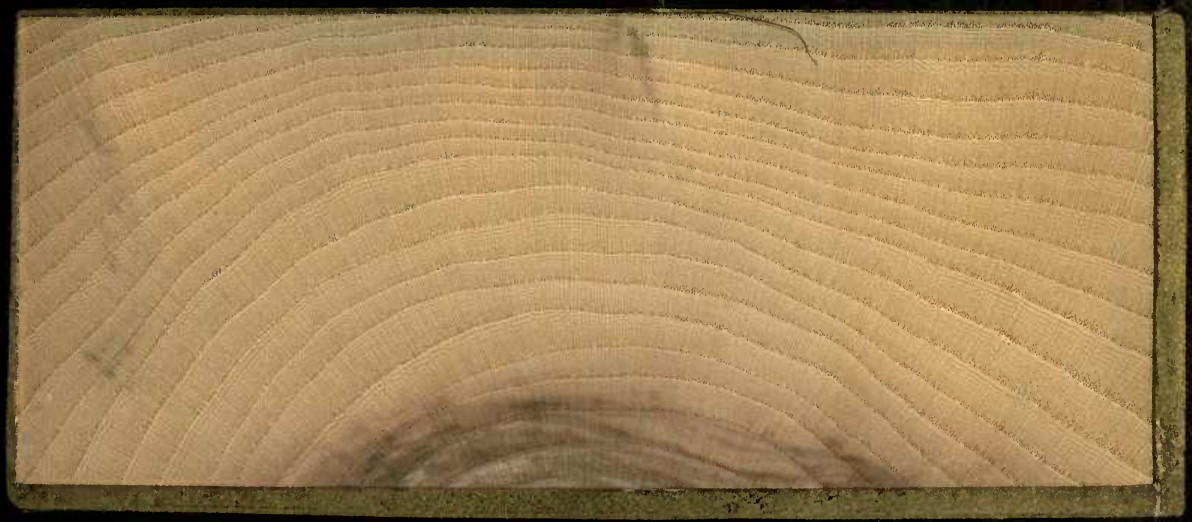

THNOVEREE SETVON.

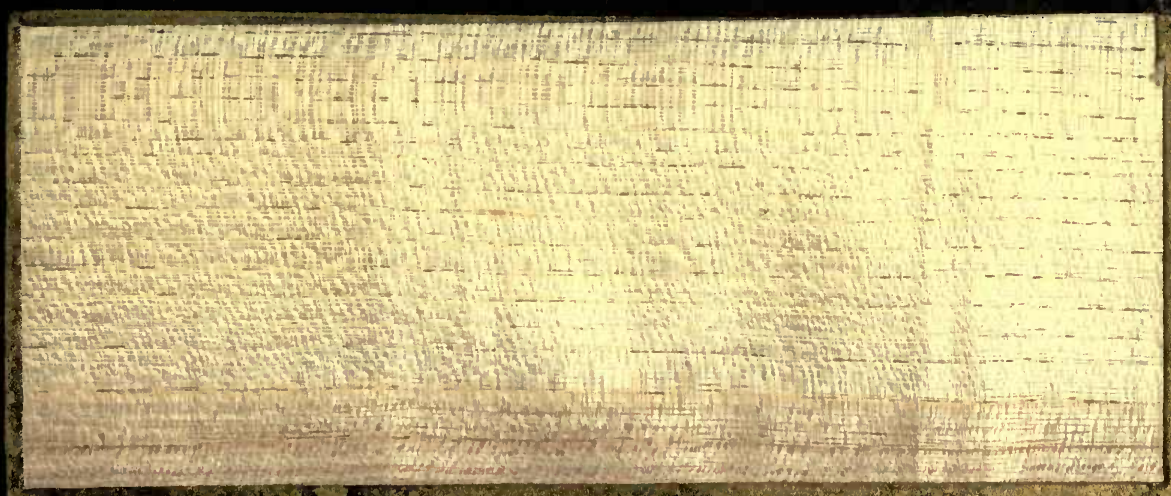

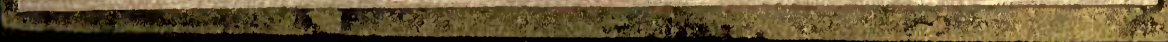

RADIAL SETTION.

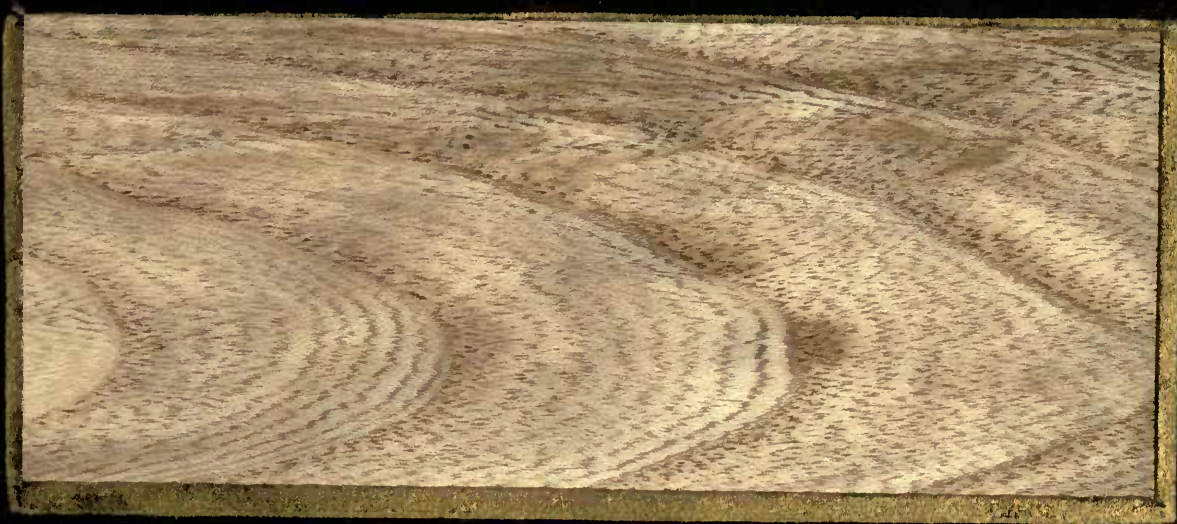

Tawasuren derow.

Circ. Abendländischer Zürgeltaum. Sp. Almoz Amoricano. Tha, Mieoconlier oceidental. 
12. CELTIS OCCIDENTALIS, L.

Sigarberry, Hackberry, Nettle-Tree, False Blas.

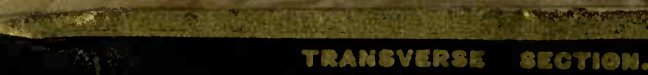

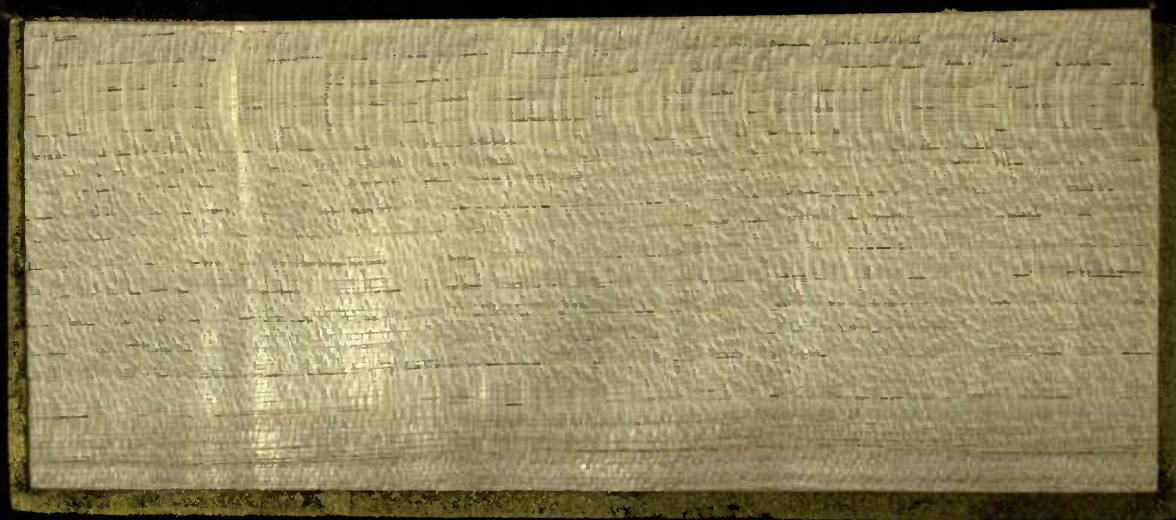
RaDiah SEOTION.

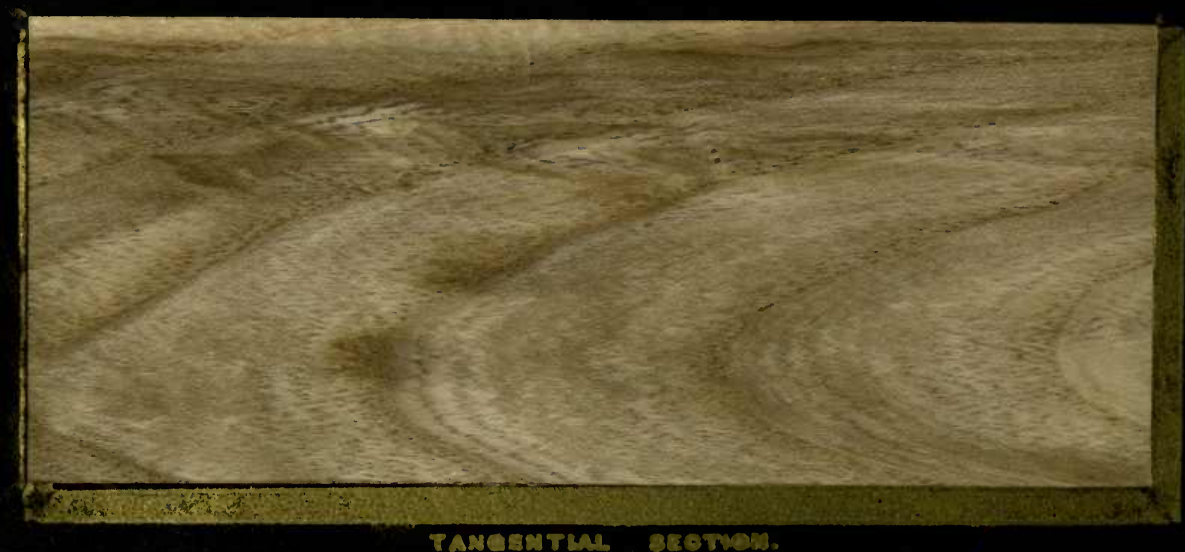

Ter. Abendländischer Zürgeltaum. Spo Almaz Azaricano. 㭥, Micoconlior oceidental. 
16. PLATANUS OCGIDENTALB, L.

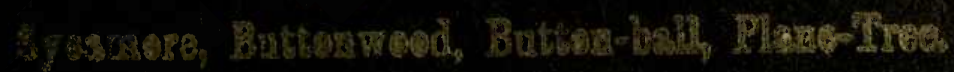

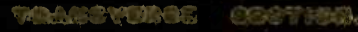

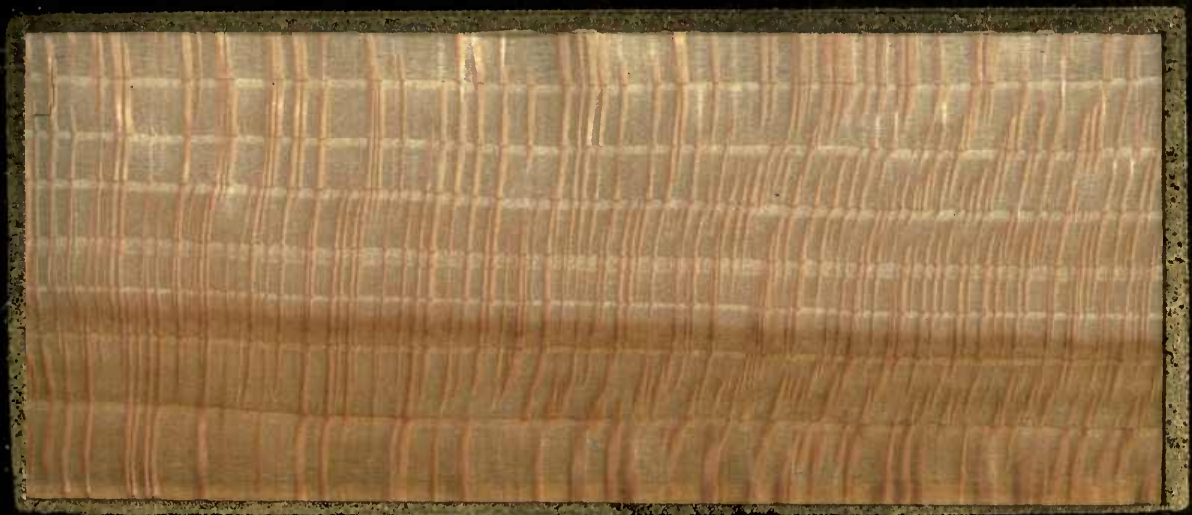

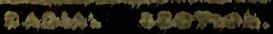

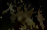

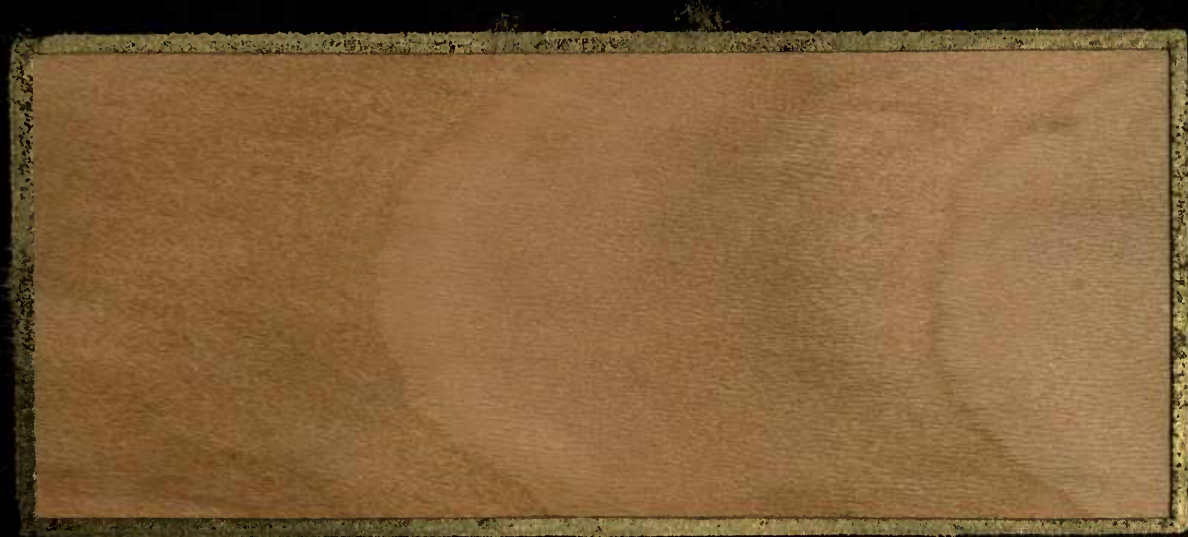

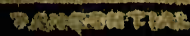

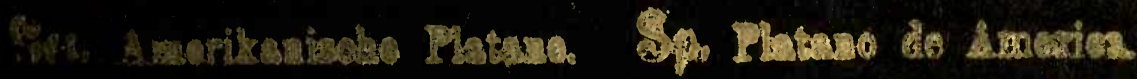

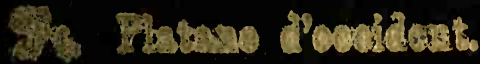


13. Platanus ogcioentalis, L

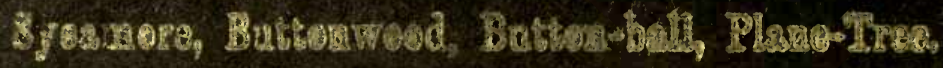

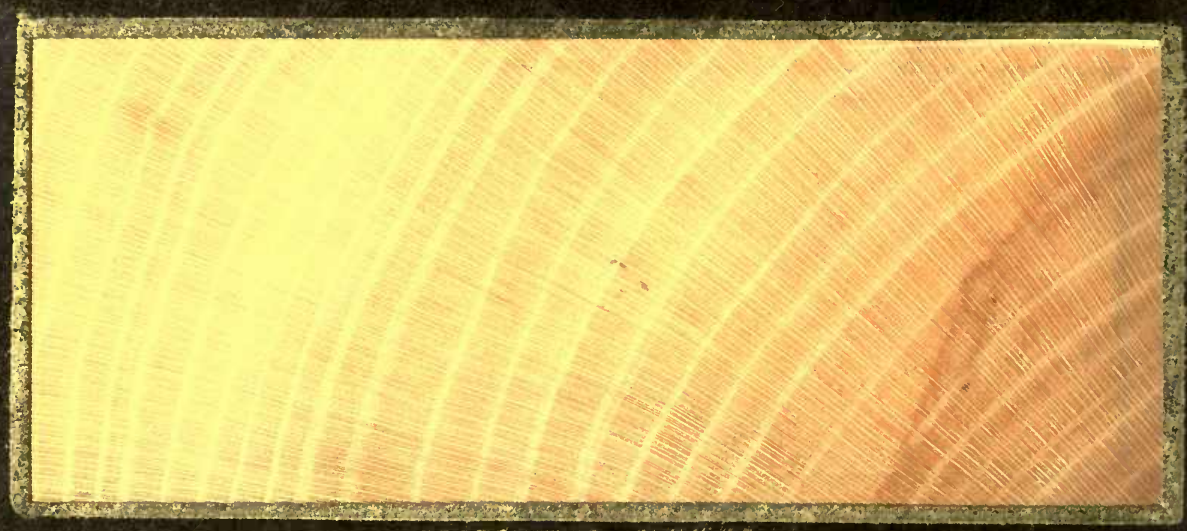

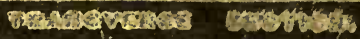

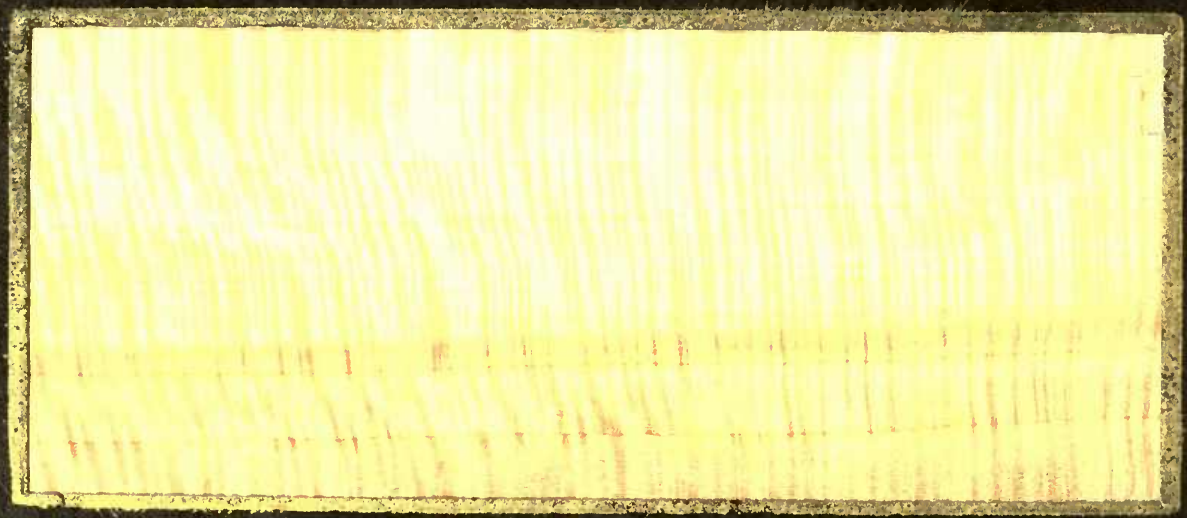

Dasuri cesenos:

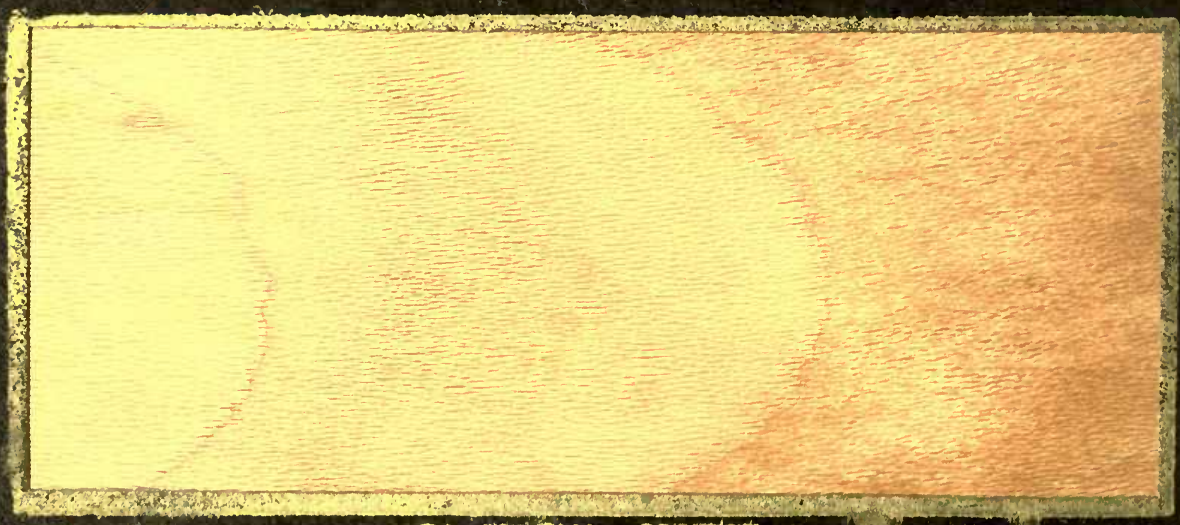

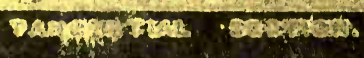

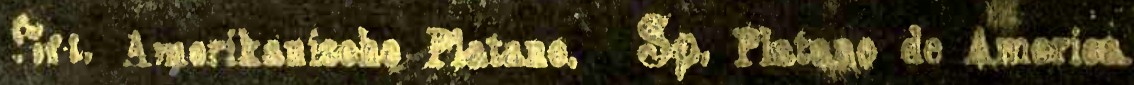

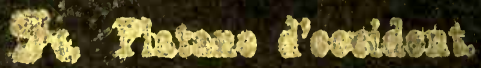




\section{JUGLANS CINEREA, L.}

Butternut, White-Walnut, Oil-Nut.

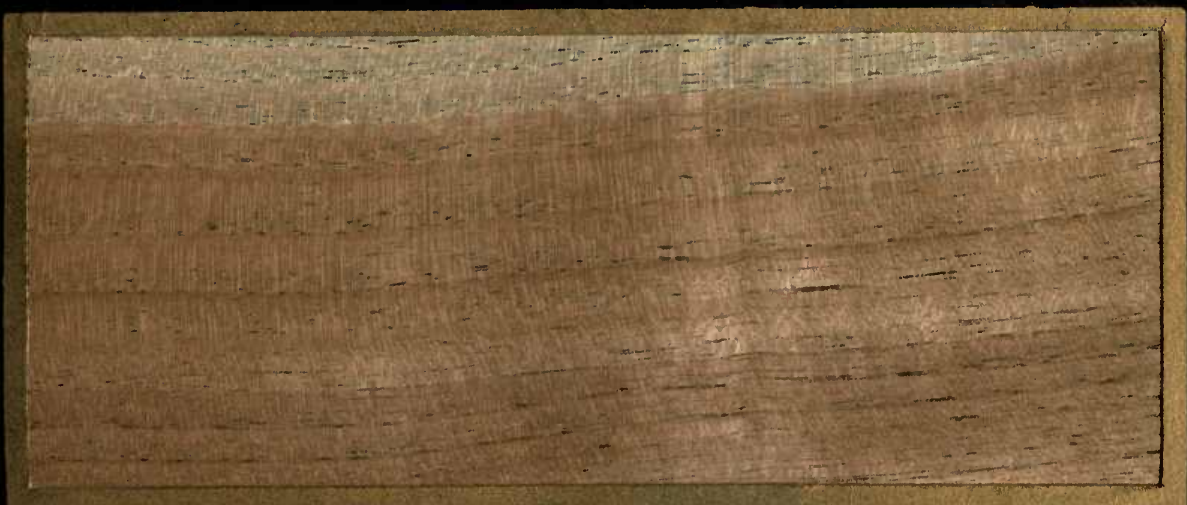

RADIAL SEOTION.

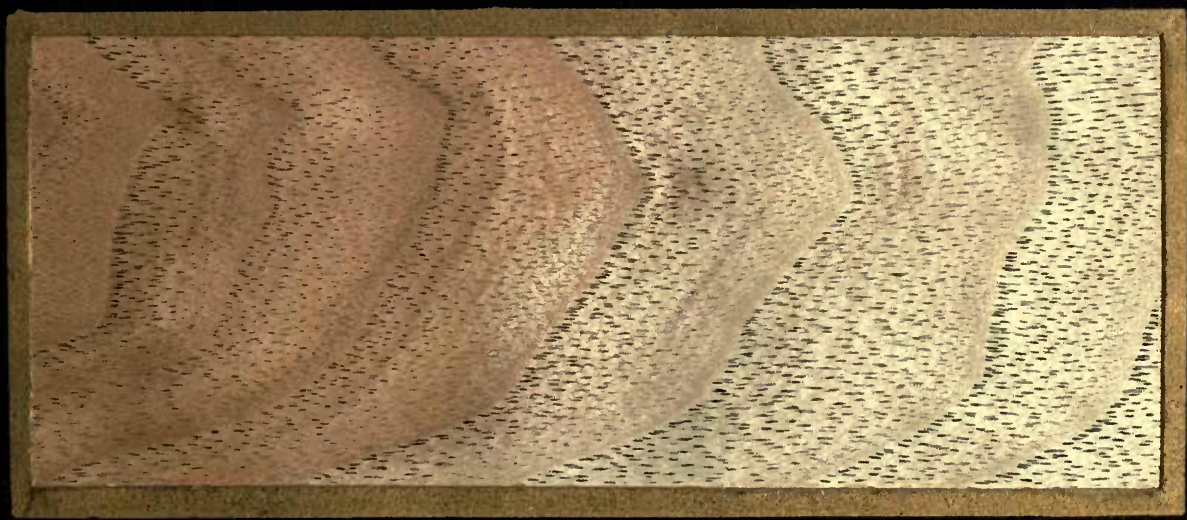

TANOENTIAL SEOTION.

Ger Aschgrauer Wallnuszbaum, Spr. Nogal gris.

Tas. Noyer cendré. 
14. JUGLANS CINEREA, L.

Butternuty White-Walnut, Oil-Nut,

TRAMOVEROE SEOTION.

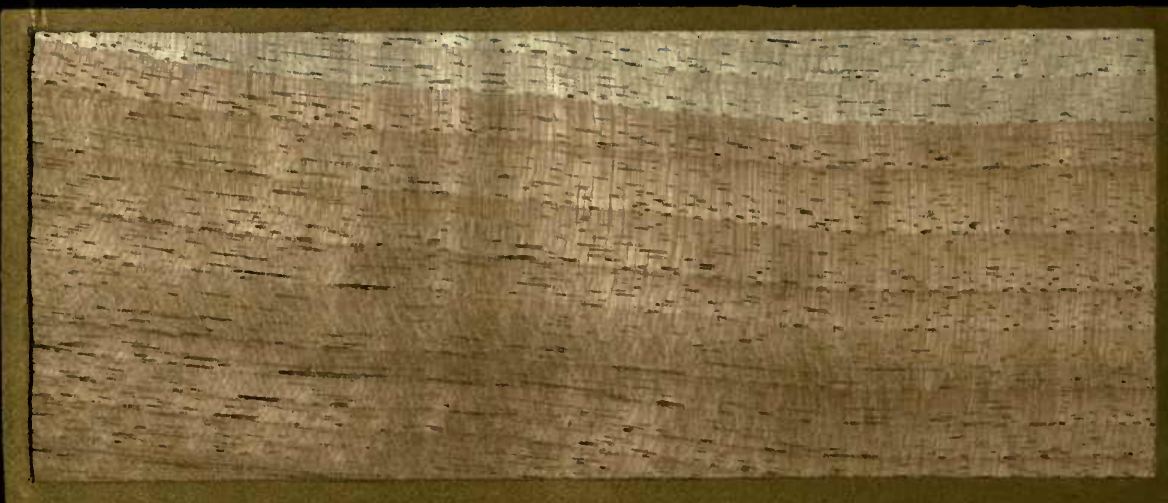

RADIAL SEOTION.

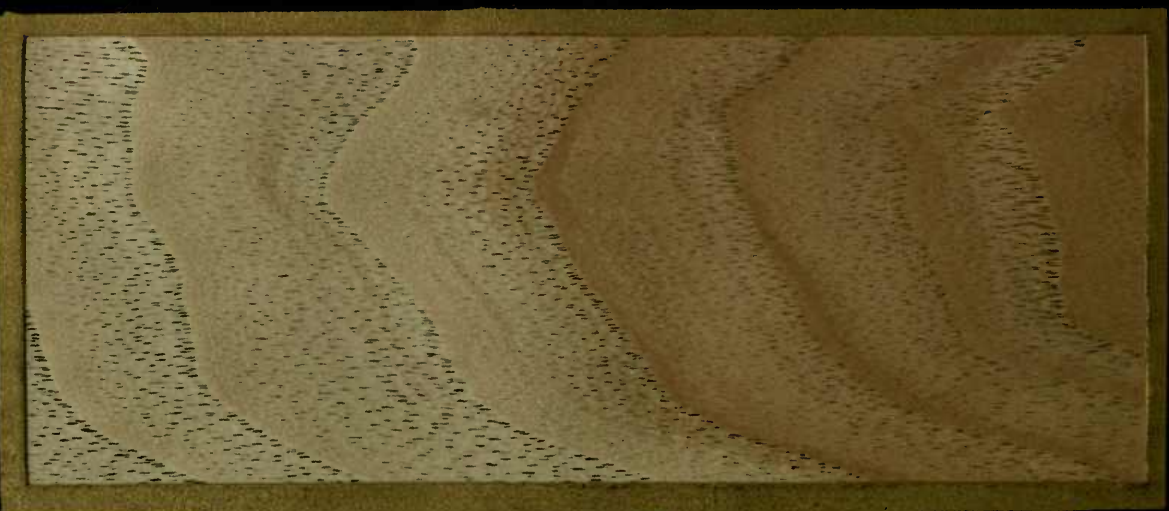

TANOENTIAL SECTION.

Ser, Aschgrauer Wallnuszbaum. Sp, Nogal gris. Tìn. Noyer cendré. 


\section{QUERCUS RUBRA, L.}

Red Oaks

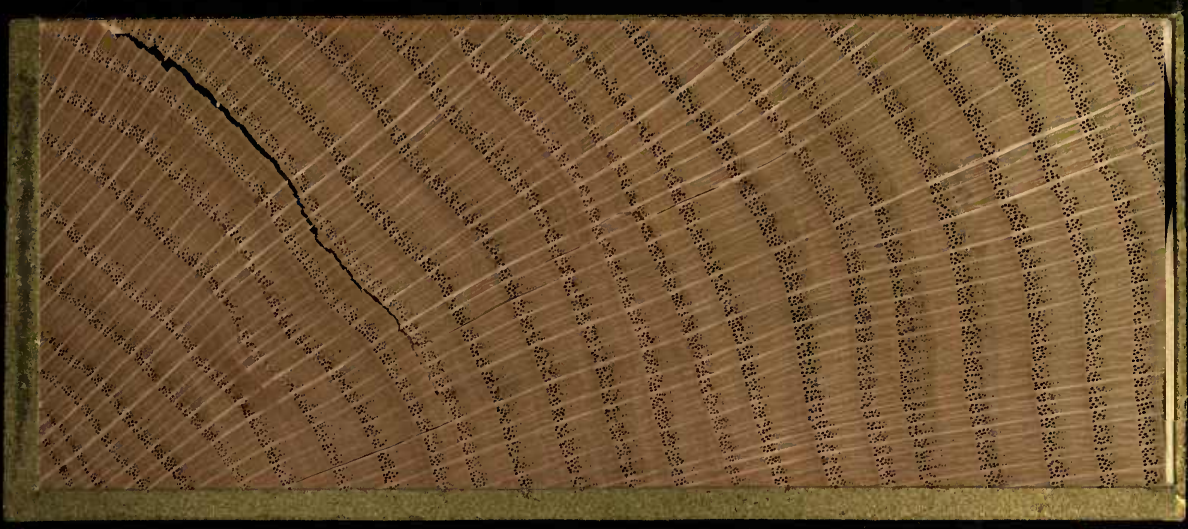

TRAMBVHREE SEOTION.

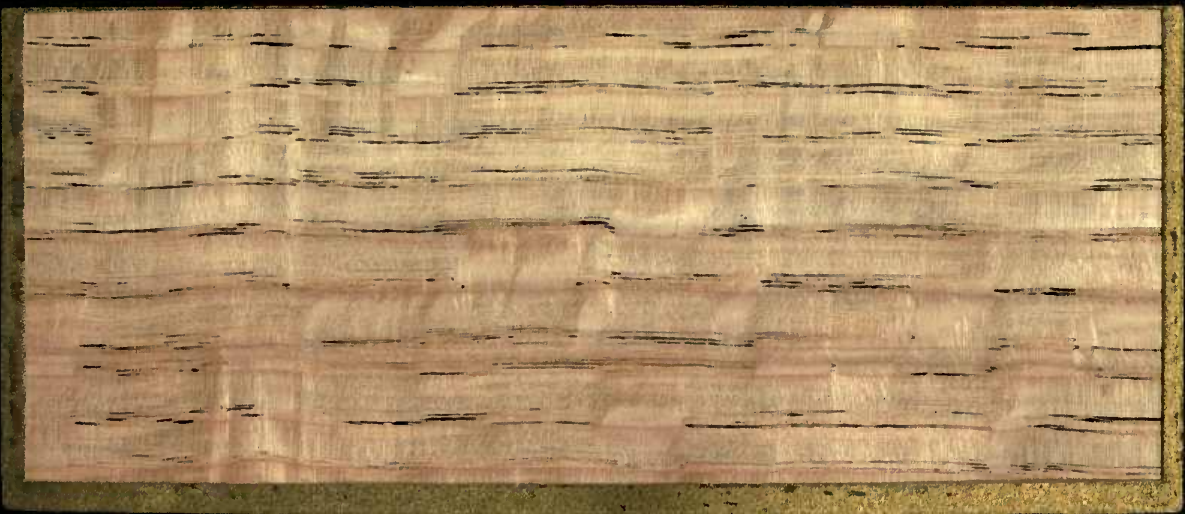

radiar orotron.

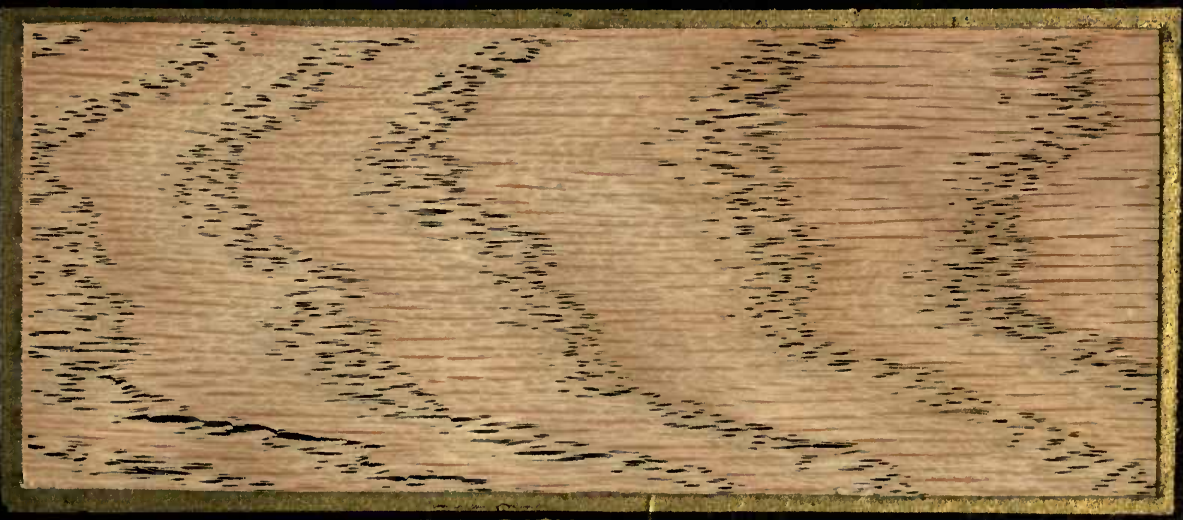

TAMGESTAL ELTION.

Ser. Roth Eiche.

Tợn, Chêne rouge.

Spp, Roble rojo. 
15. QUERGUS RUBRA, L.

Rod Oaks

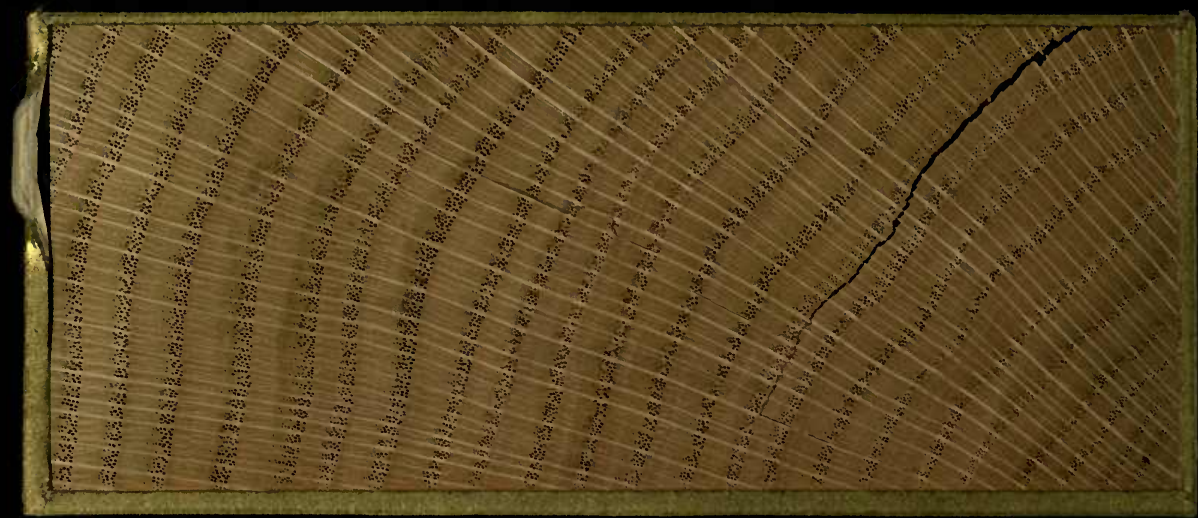

Tonasvense serstow.

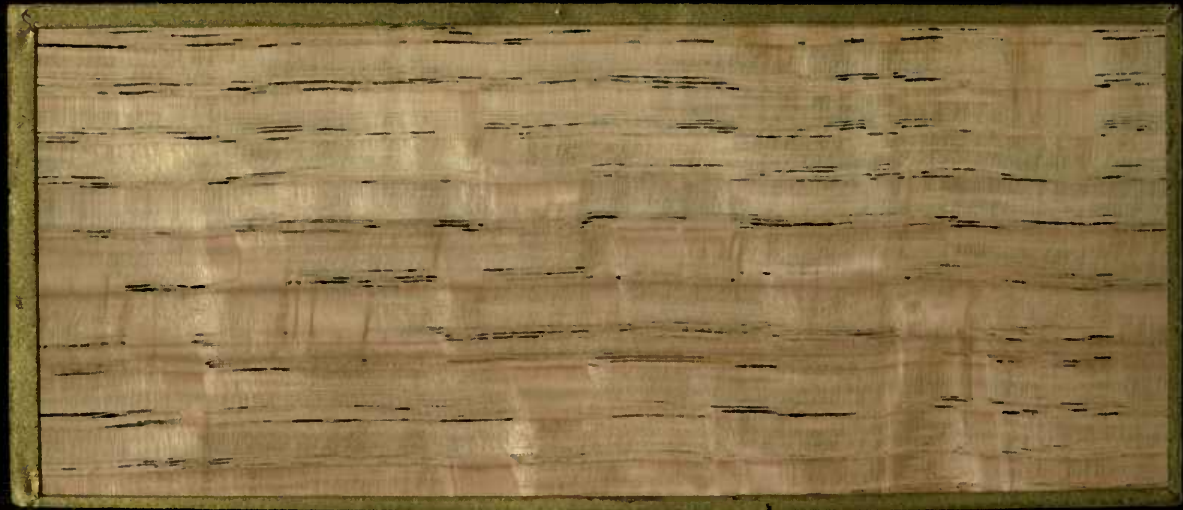

AADIAL Berion.

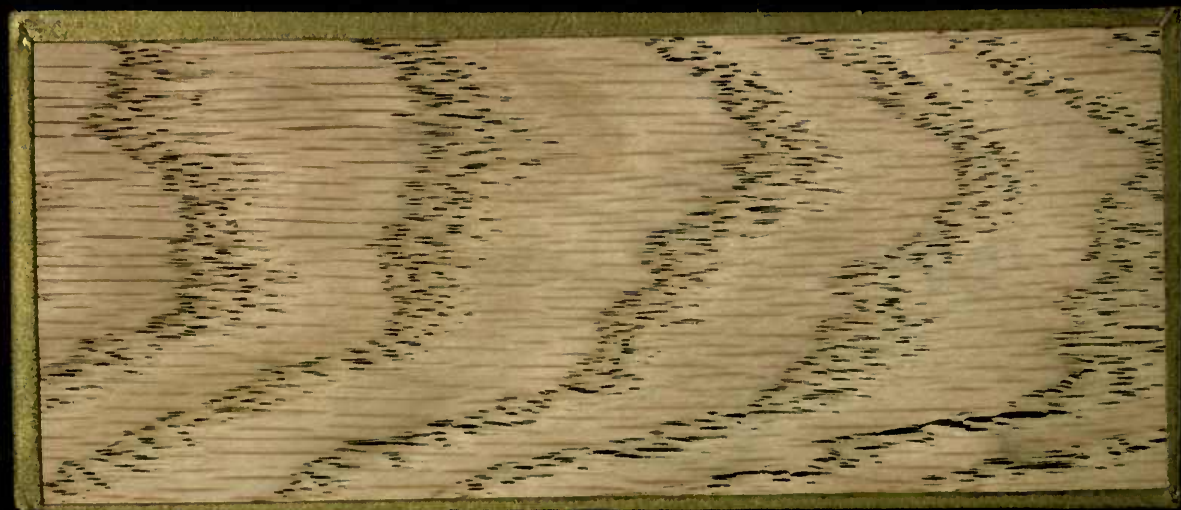

Taworatras Dection:

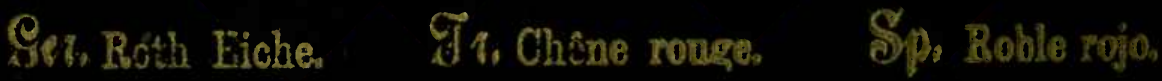


16. FAGUS FERRUGINEA, AIT.

Amerioan Boech.

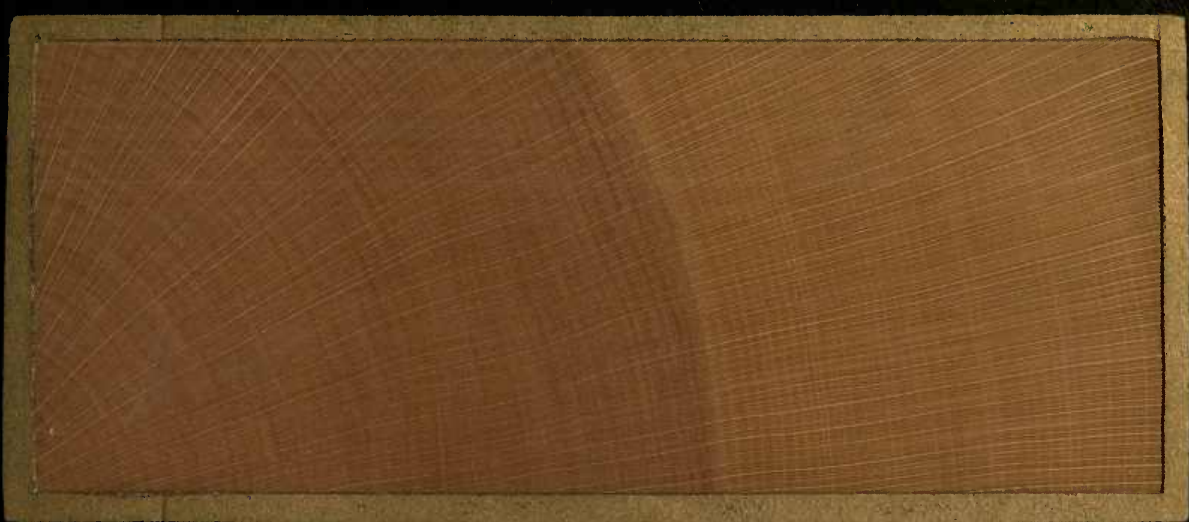

TRAHOVERER EEOTION.

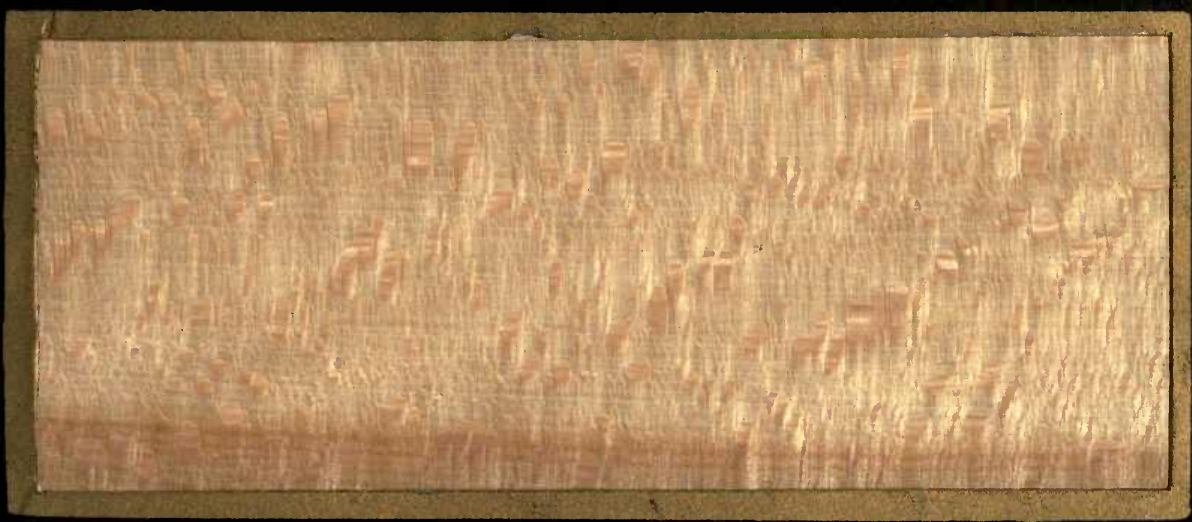

RADIAL BLOTIOS

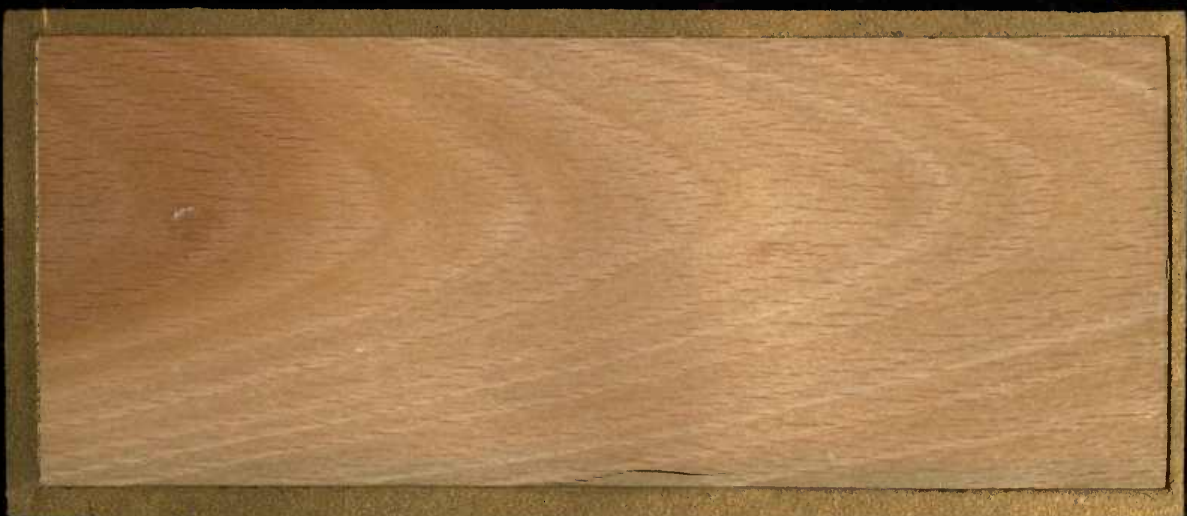

TANOENTIAL BEOTION.

Ser Amerikanischo Bucho; Sp, Haya Amorioaina. Gist Hêtre d'Amerique. 
16. FAGUS FERRUGINEA, Ait.

American Beoch.

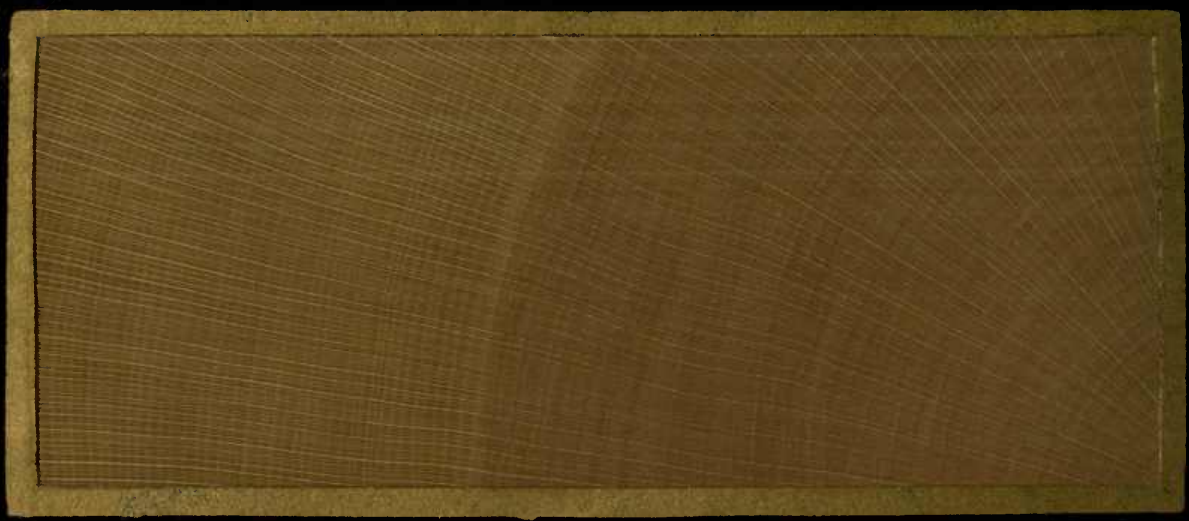

TRAMOVERoE esotion.

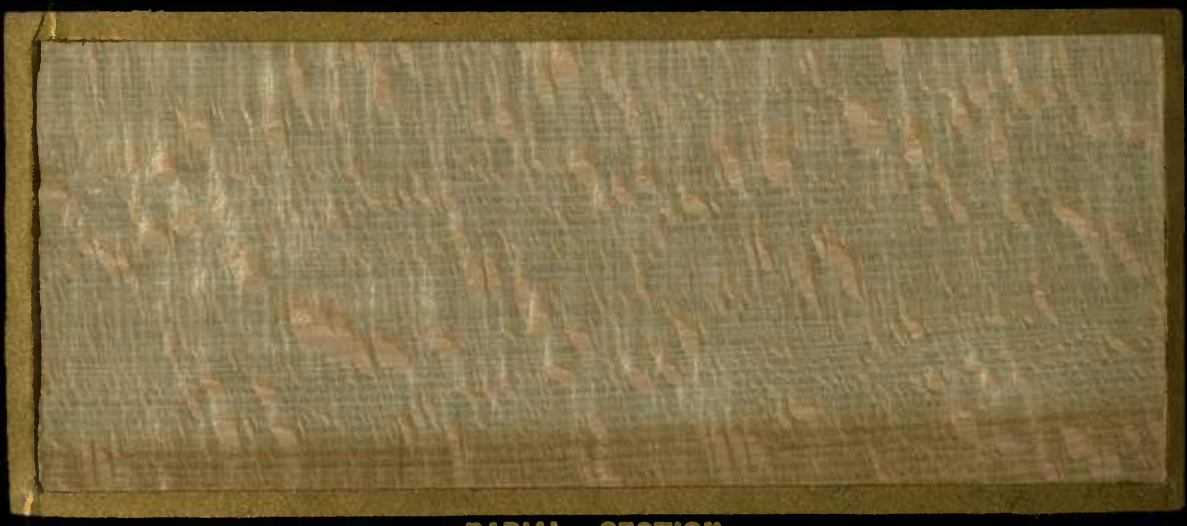

BADIAL OEOTIOW

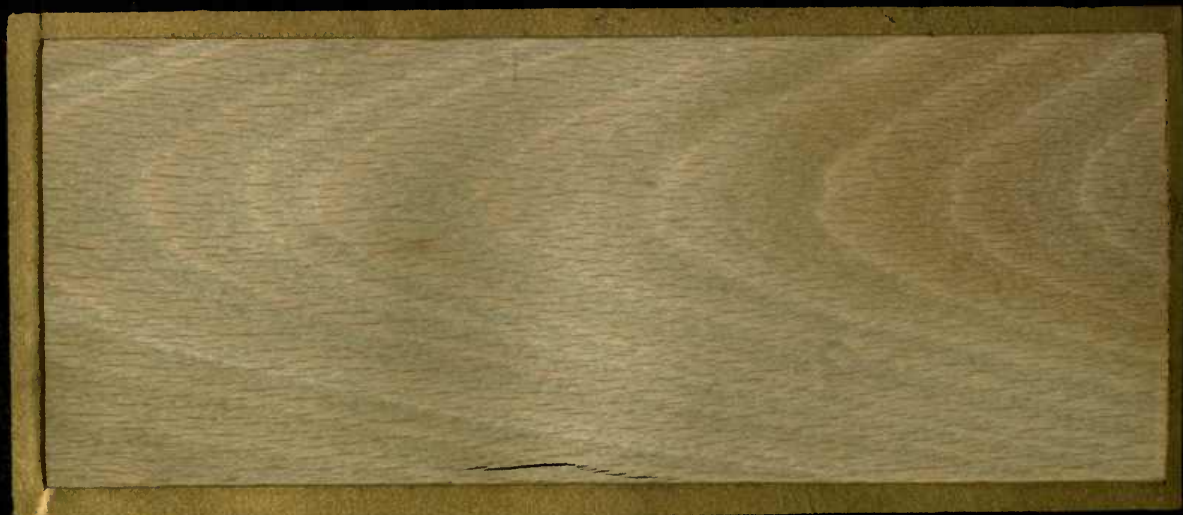

TANOSNTHL EROTION.

Sen Amerikanische Buchor Sp, Haya Amerioana, Tin, Hetre d'Amerique. 
17. BETULA LUTEA, Мichx. F.

Yollow Birch, Gray Birch.

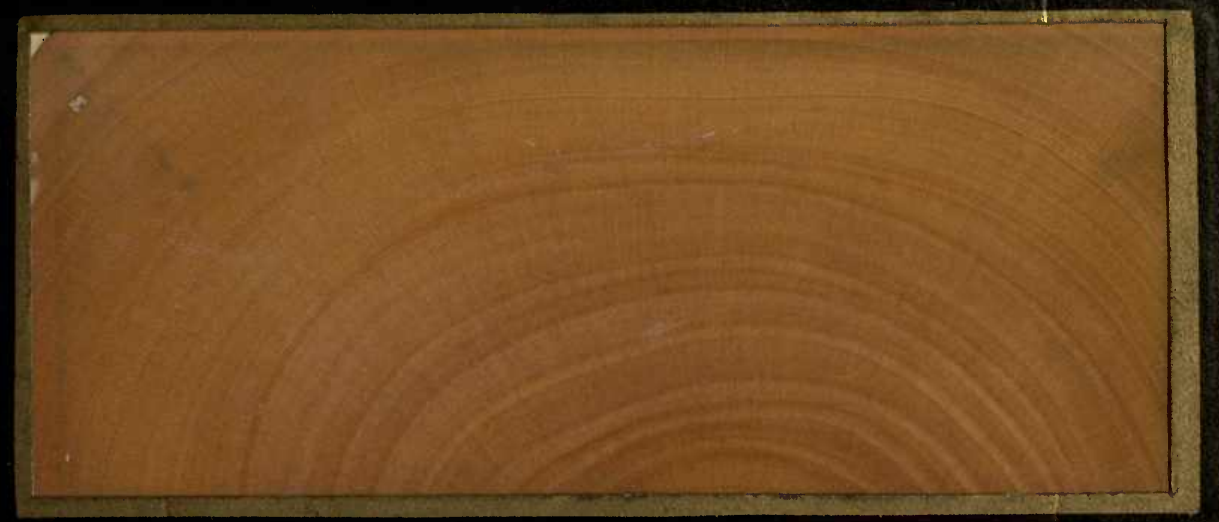

TRAMOVEREE SETTION.

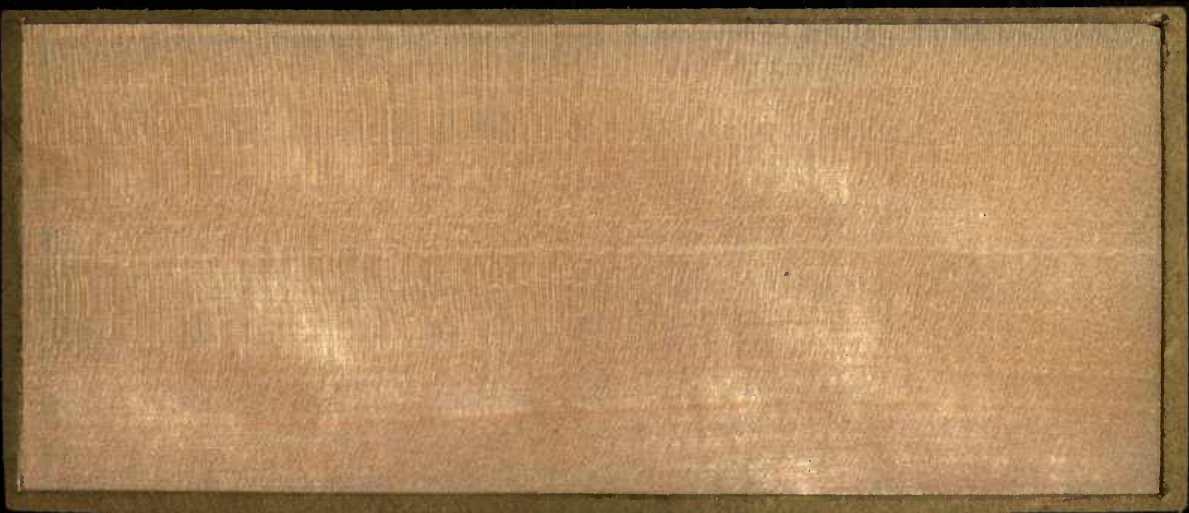

RADIAL SEOTION.

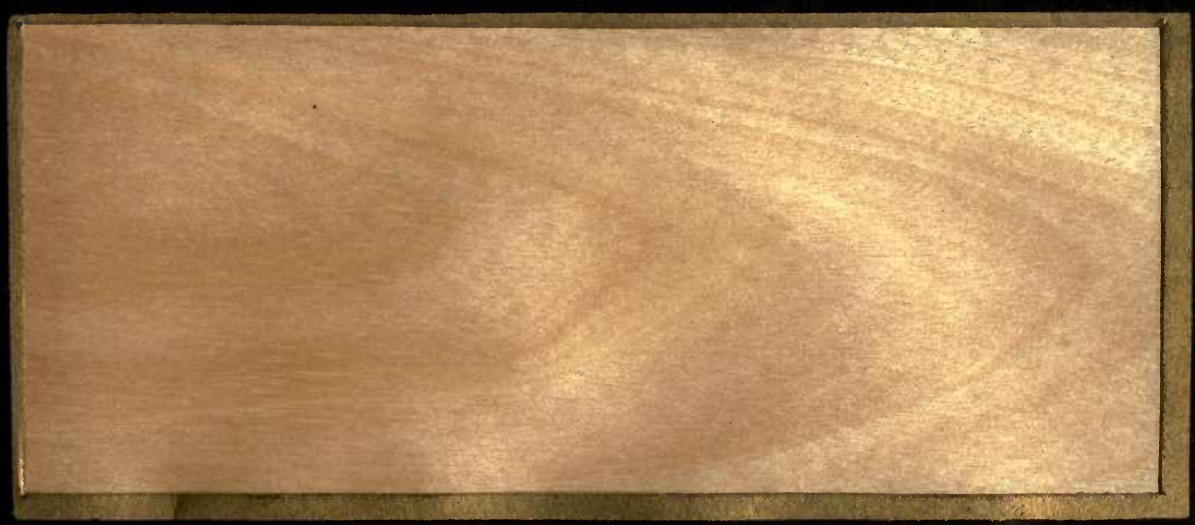

TANOENTIAL BEOTION.

Sen Geilbe Birker Givi Bouleau jaune. Sp, Abedul amarillo. 
17. BETULA LUTEA, Michx. F.

Yollow Birch, Gray Birch.

TANOENTIAL SEOTION.

Sen Gelbe Birke. Gin Bouleau jaune. Sp, Abedul amarillo. 
18. POPULUS GRANDIDENTATA, Michx. Large-toothed Poplar or Aspen, Large Poplar, White-Wood.

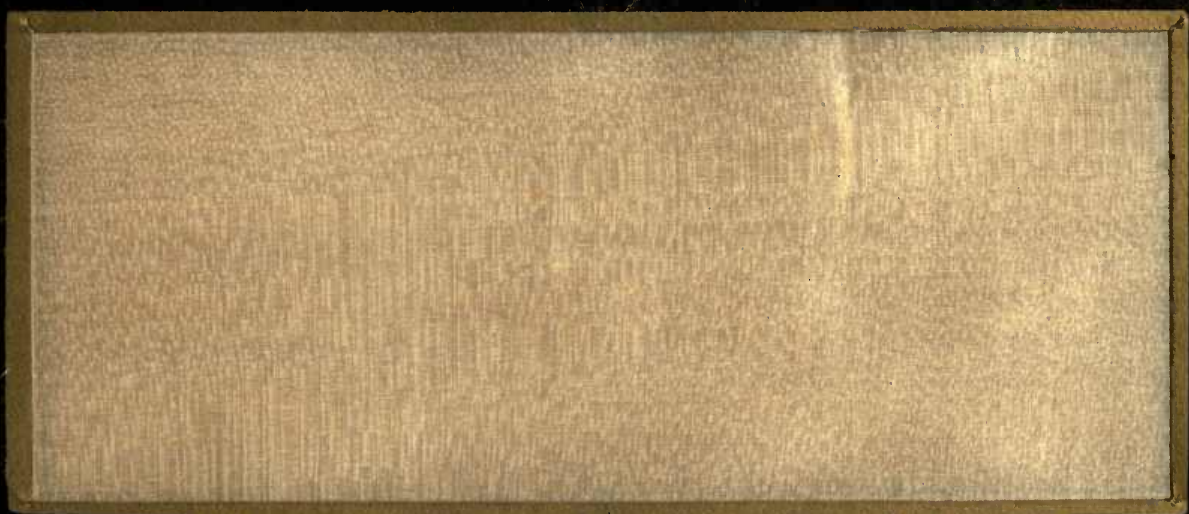

RADIAL SEOTIOW.

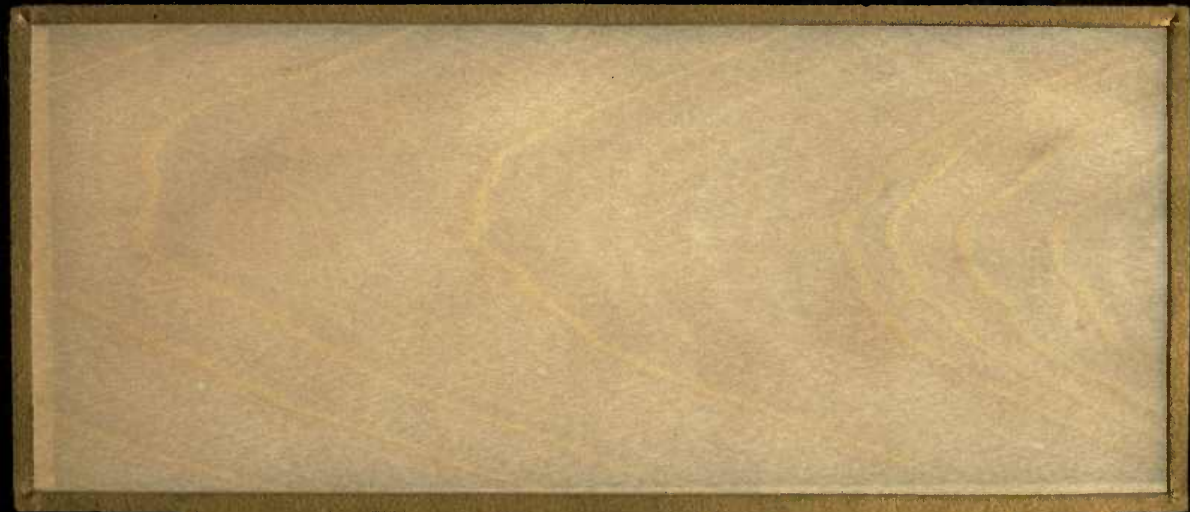

TAMOENTIAL BEOTION.

Ser, Groszgezänte Espe. Sp, Alamo de diente grande. ditr. Peuplier à grandes dents. 


\section{POPULUS GRANDIDENTATA, МichX.}

Large-toothed Poplar or Aspen, Large Poplar, White-Wood.

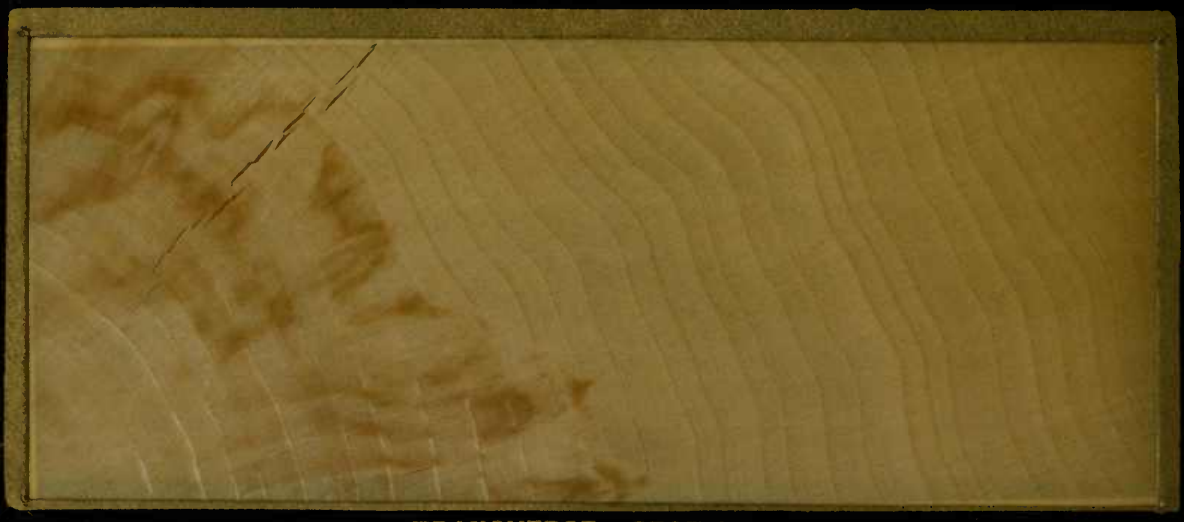

TRAMSYERSE SEOTION.

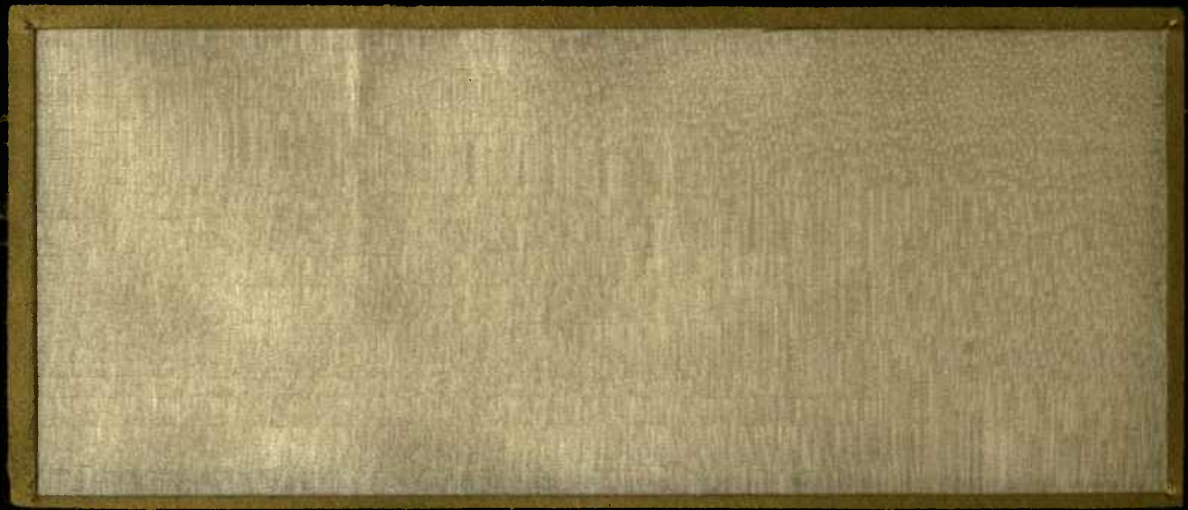

BADIAL EETHOH.

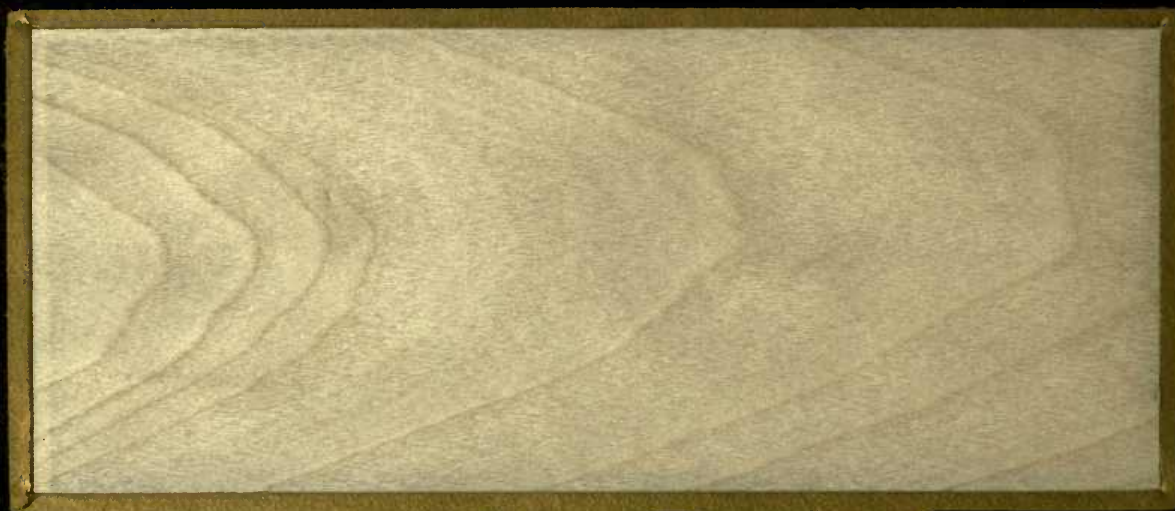

TAMOENTIAL BEOTIOH.

Ser, Groszgezänte Espe. Sp, Alamo de diente grande. Tit Peuplier à grandes dents. 
19. PINUS RESINOSA, AIT.

\section{Red Pine,}

\section{"Norway" Pine.}

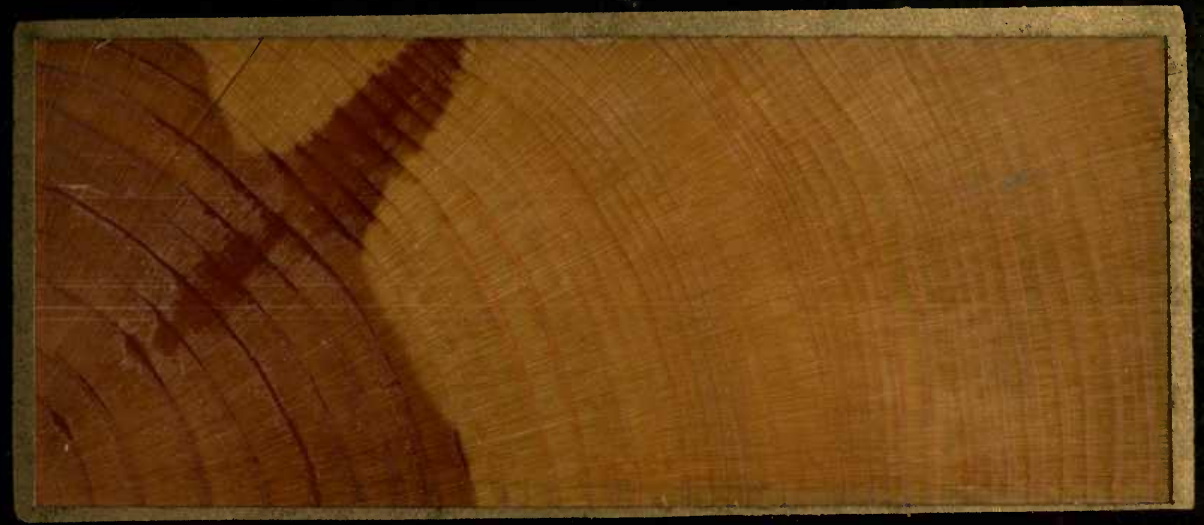

TRACSVERSE STOTION.
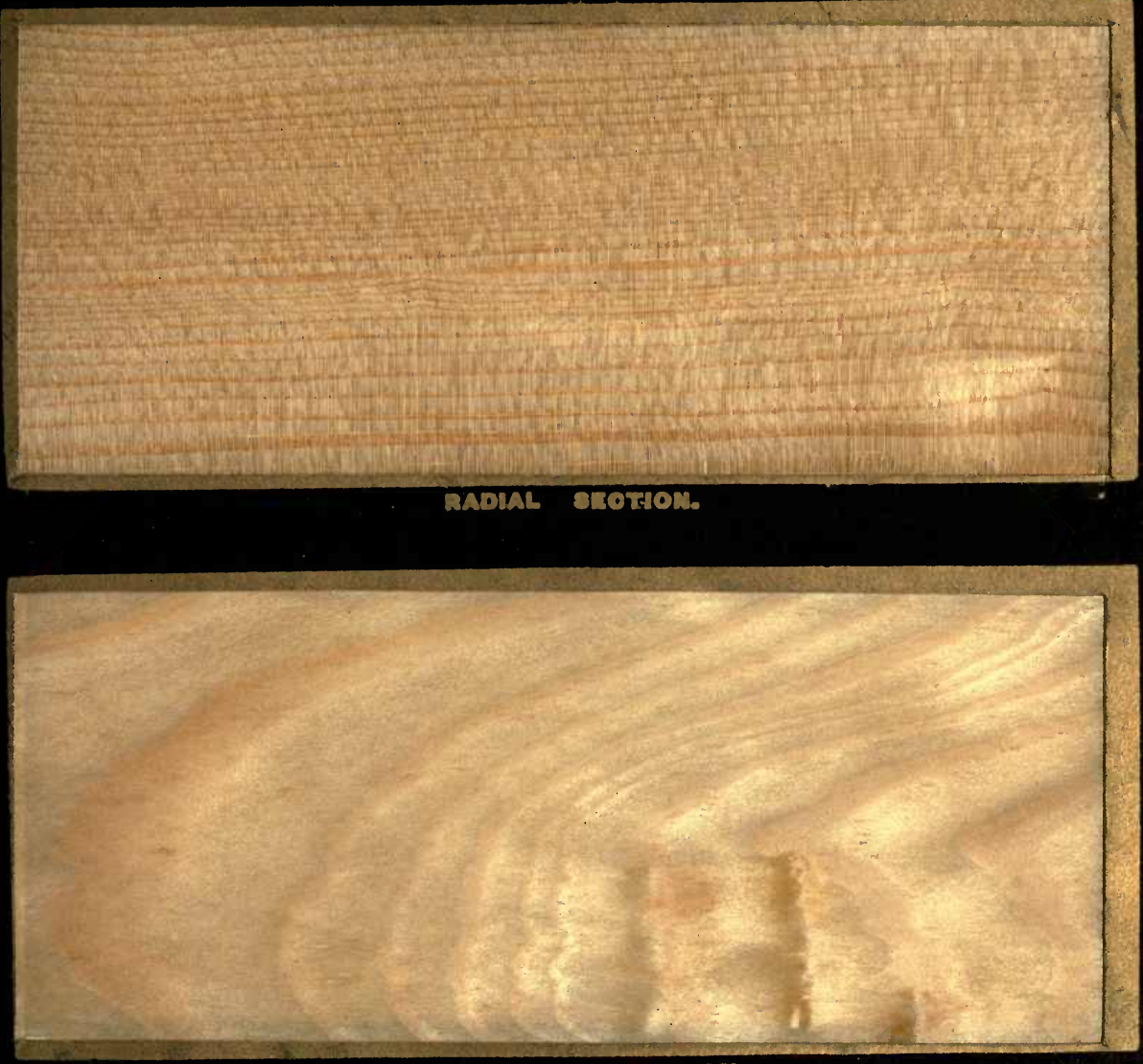

TAKOENTAL BEOTOW.

Sen Harrige Fichte。 Gis Pin rouge, Sp, Pino rizado. 
19. PINUS RESINOSA, AIT.

Red Pine,

"Norway" Pine,

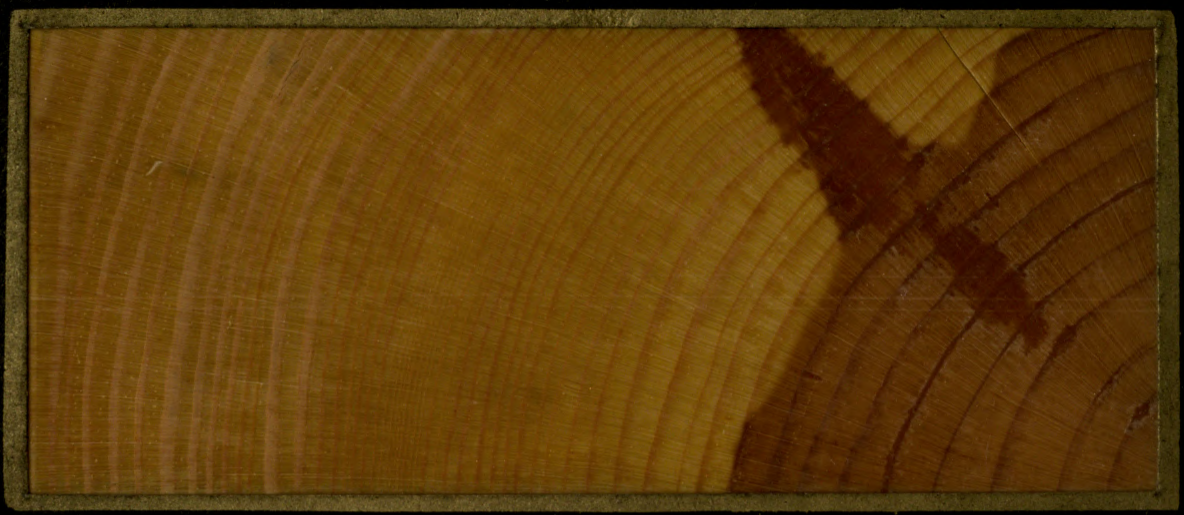

TRAMSVERSE SECTION.

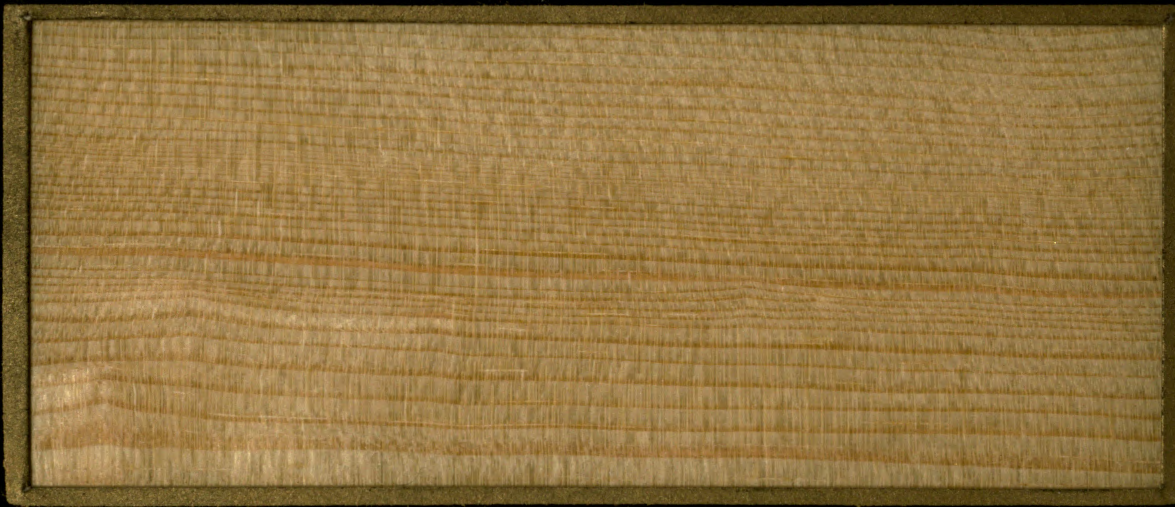

RADIAL EIOTION.

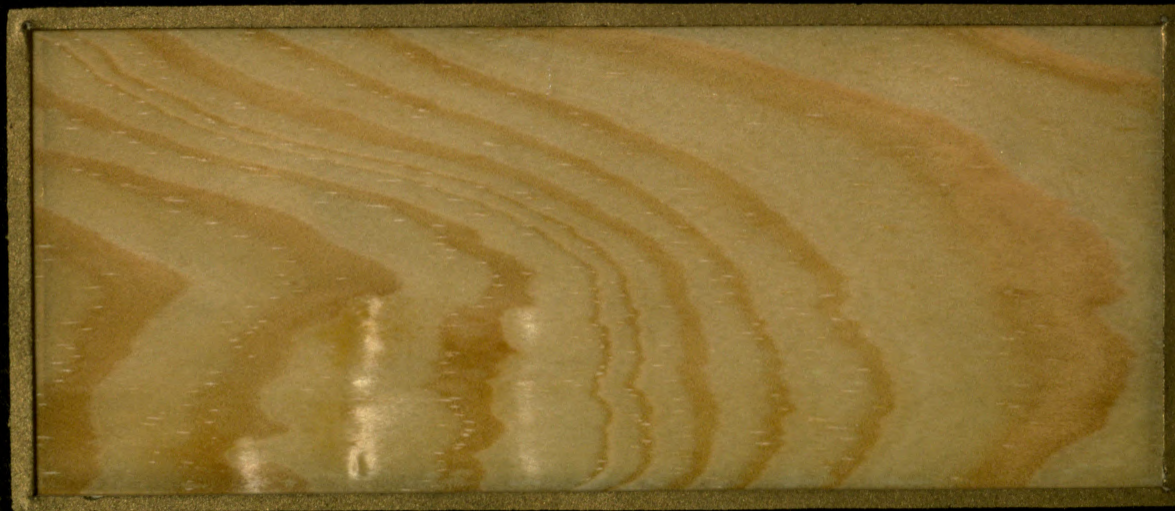

TANOEMTIAL SEOTION.

Ger, Harzige Fichte, ginn, Pin rouge. Sp, Pino rizado. 
20. ABIES NIGRA, 'PoIr.

Black Spruce, Double Spruce, Red Spruce.

TRANGVEREE SEOTION.

RADIAL SEOTIOL

TANOENTIAL SEOTION.

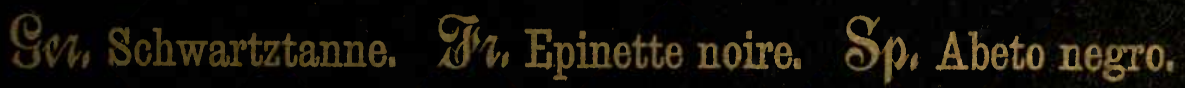


20. ABIES NIGRA, PoIr.

\section{Black Spruce, Double Spruce, Red Spruce.}

TRANEVERSE SECTION

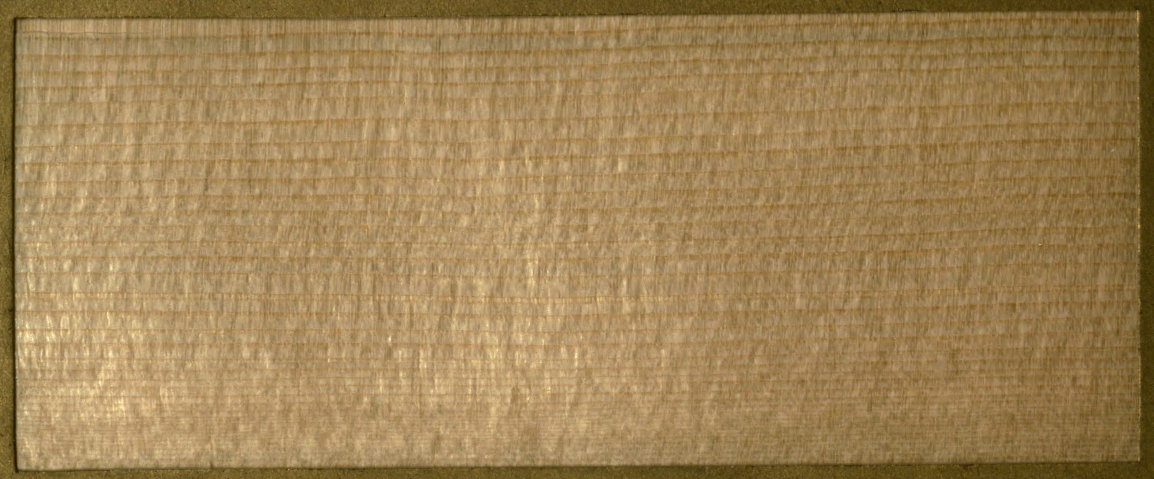

RADIAL BETTIOL.

TANCENTIAL SECTION.

Ger, Schwartztanne. Tiv" Fininette noire. Sp, Abeto negro. 
21. ABIES CANADENSIS, MionX.

Hemlock,

Hemlock Fir.

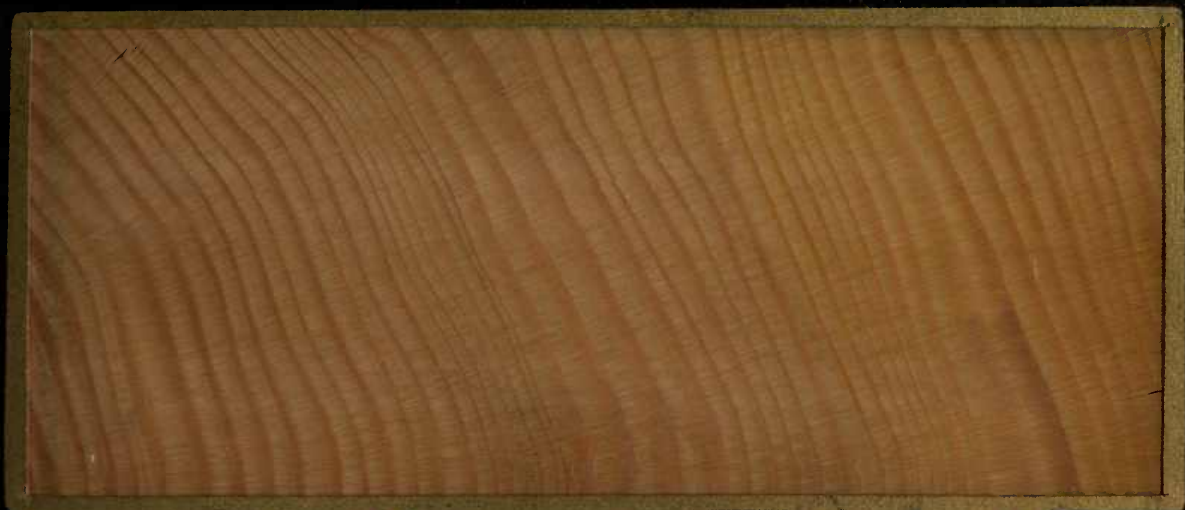

TRANBVERSE SECTION.

RADIAL SECTIOH.

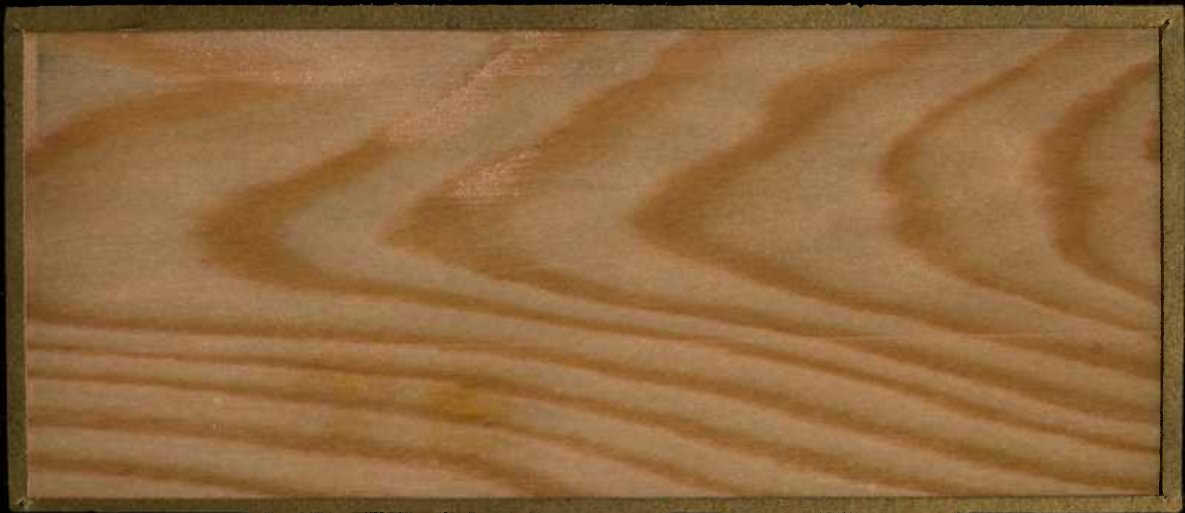

TANOENTIAL SESTIOA.

Gen Schierling-Tanne. TH, Peruche. Sp, Abeto Canadense. 


\section{ABIES CANADENSIS, MichX.}

\section{Hemlock, \\ Hemlock Fir,}

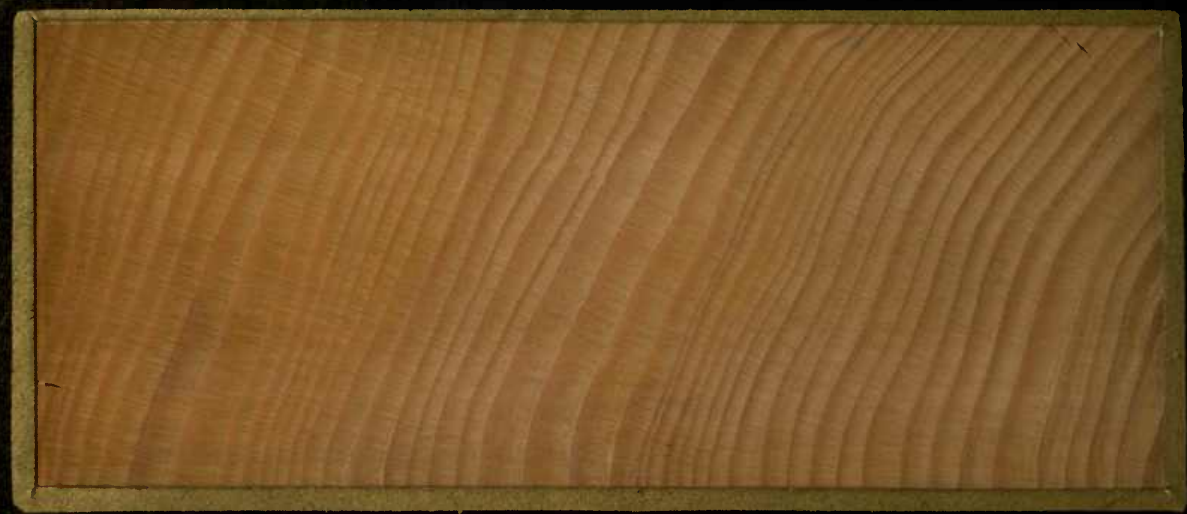

TRAMBVERSE SECTIOW.

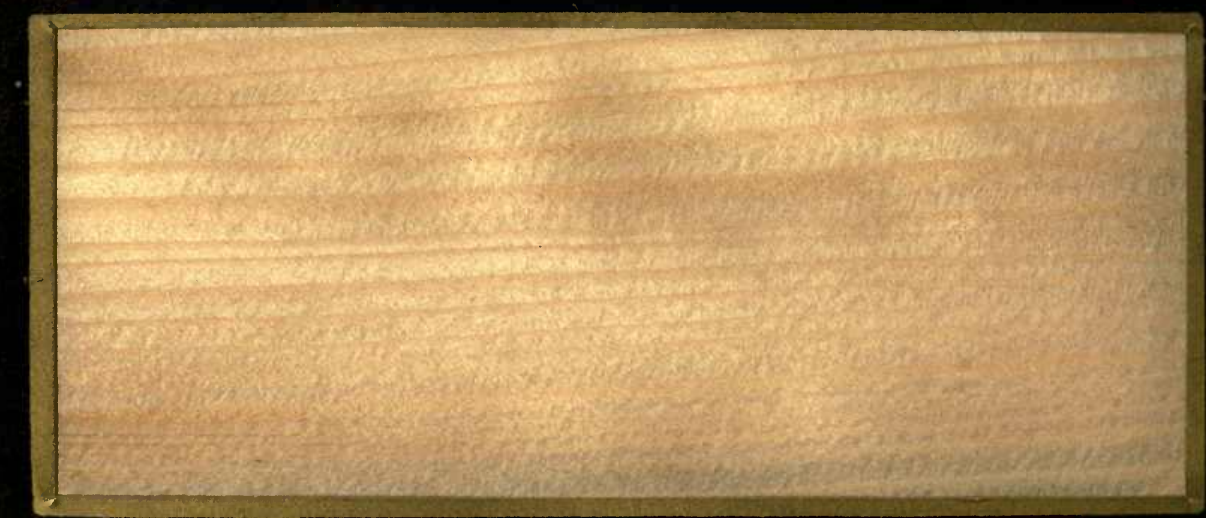

BADIAL STOTION.

TAKOENTIAL EBOTIOH.

Ser Sohiorling-Tanno. Mir Perucho. Sp, Abeto Canadense. 
22. ABIES BALSAMEA, MARSHALL.

Balsam, Balsam Fir, Balm-of-Gilead Fir.

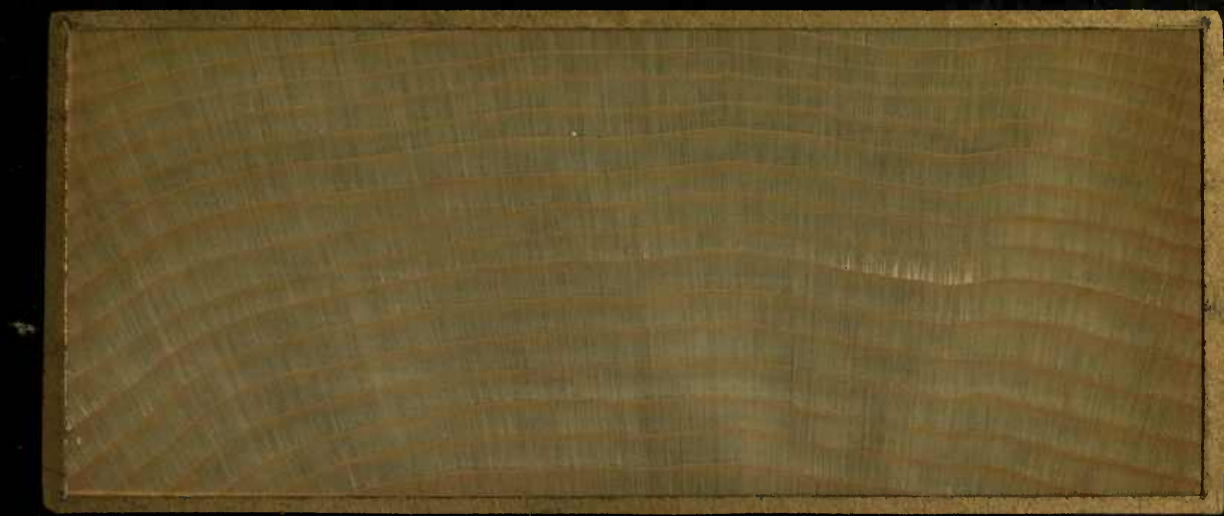

TRAKSVERSE SECTION.

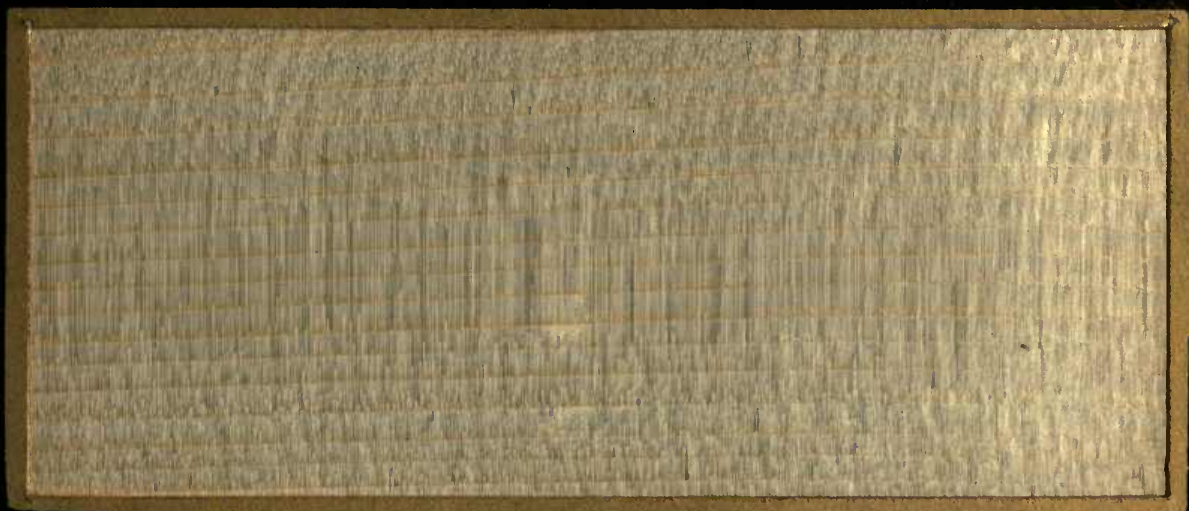

RADIAL SEOTION.

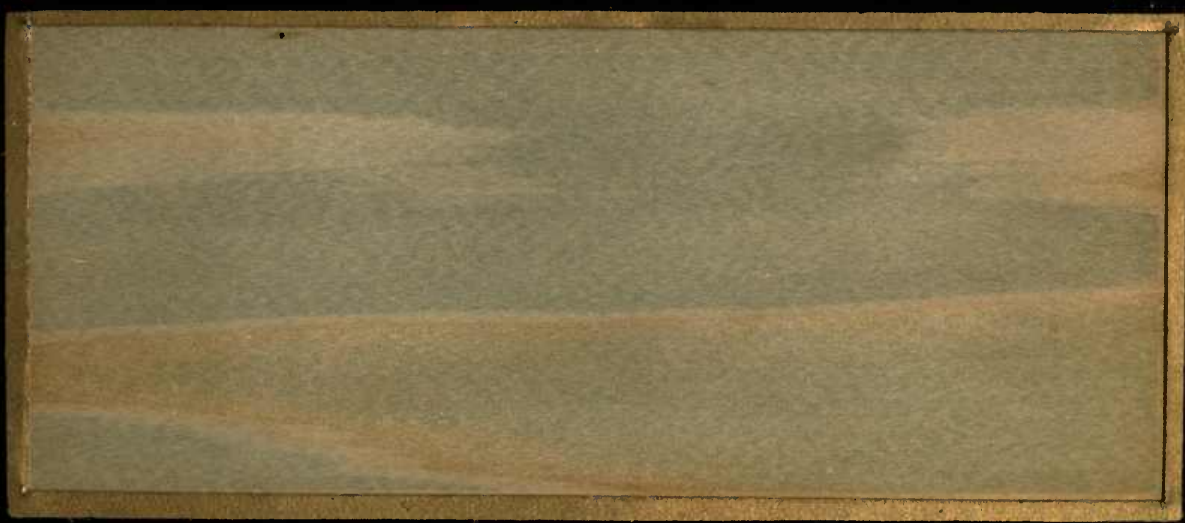

TAEOENTIAL SEOTION.

Ser, Balsam-Tanno, Sp, Abeto balsamico.

THa Sapin baumier. 
22. ABIES BALSAMEA, MARSHALL.

Balsam, Balsam Fir, Balm-of-Gilead Fir.

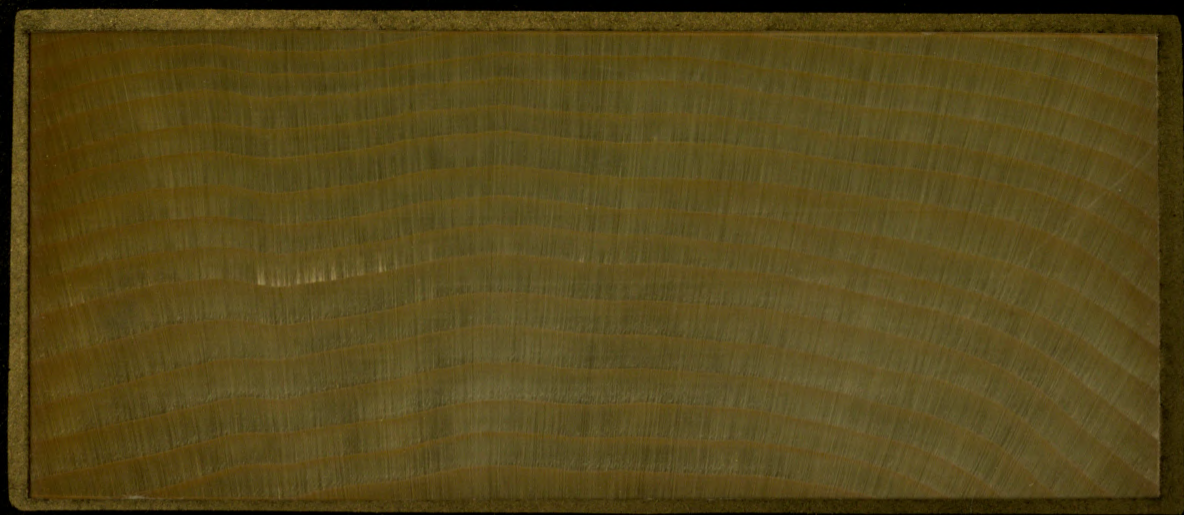

TRANSVERSE SECTION.

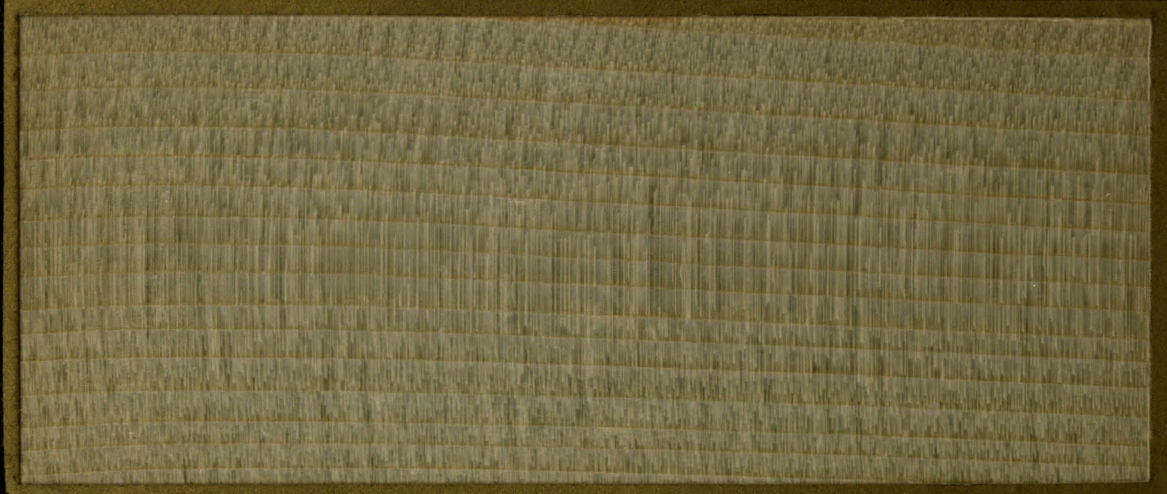

RADIAL SECTION.

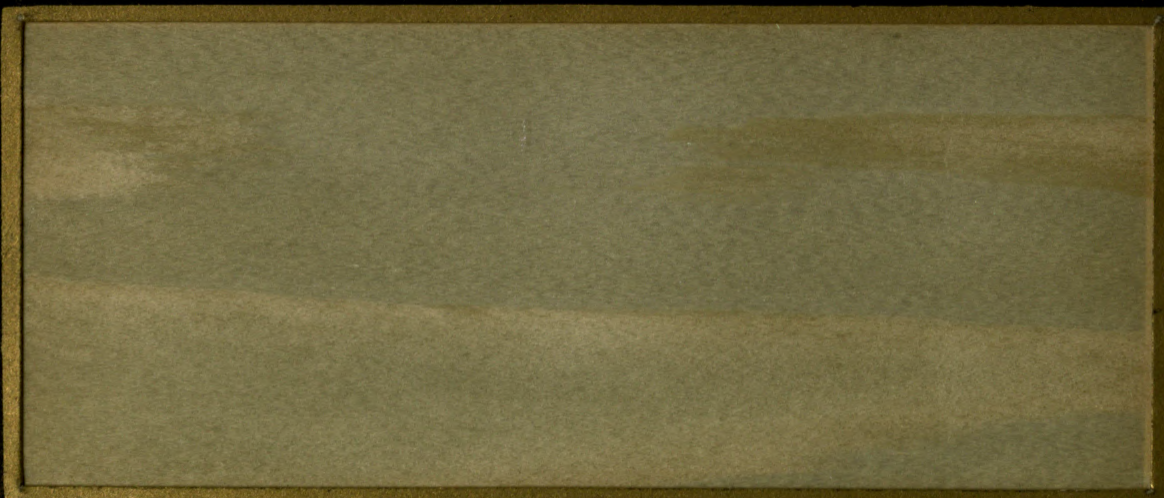

TAMOENTIAL SECTION.

Ser, Balsam-Tanne. Spr, Abeto balsamico.

Gapin baumier. 
Tamarack, American or Black Larch, Hackmatack.

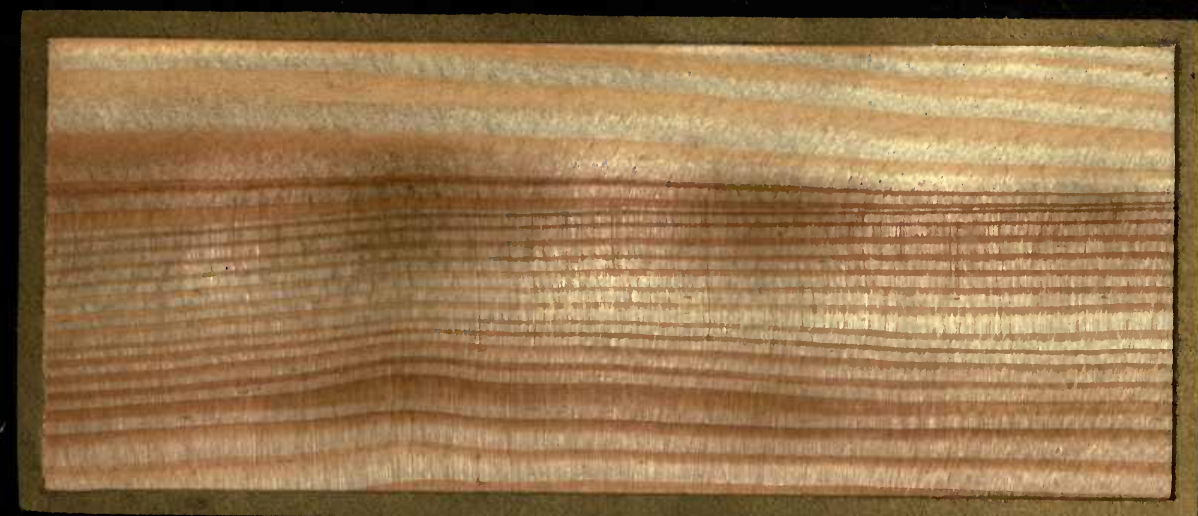

RADIAL SEOTION.

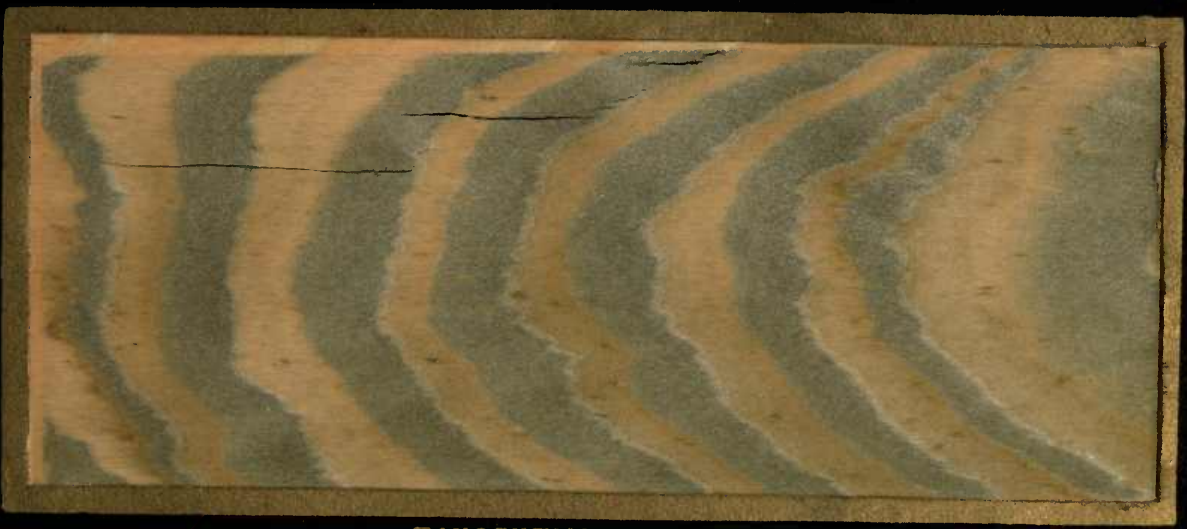

TANOENTIAL SEOTION.

Son Amerikanische Larche. Sp, Larice Americana Tir. Meleze Americain, 
23. LARIX AMERICANA, MichX.

Tamarack, Amorican or Black Larch, Hackmatack.

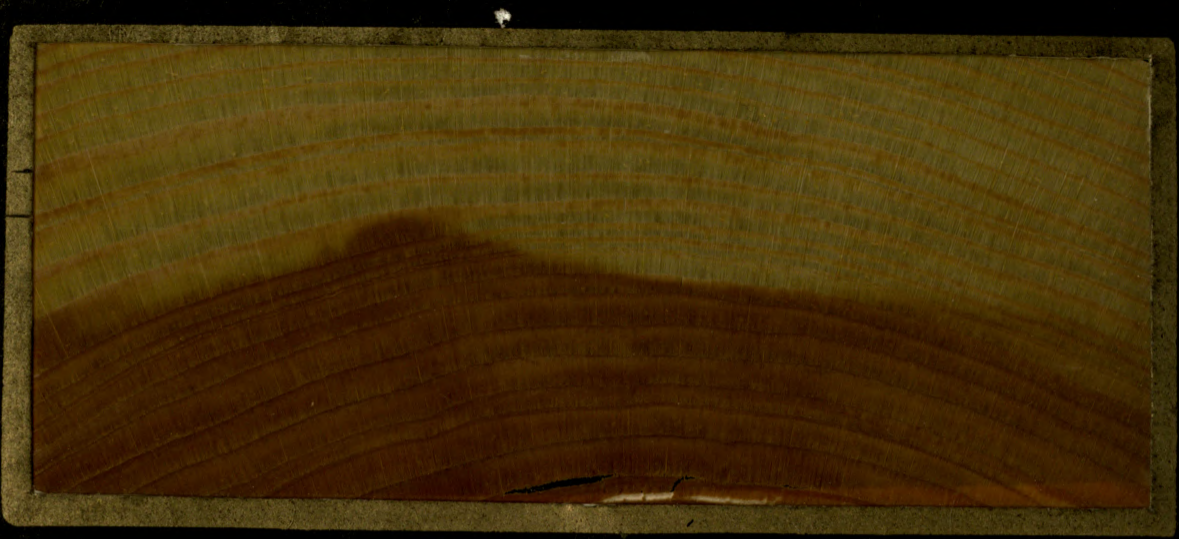

TRANBVERSE SECTION.

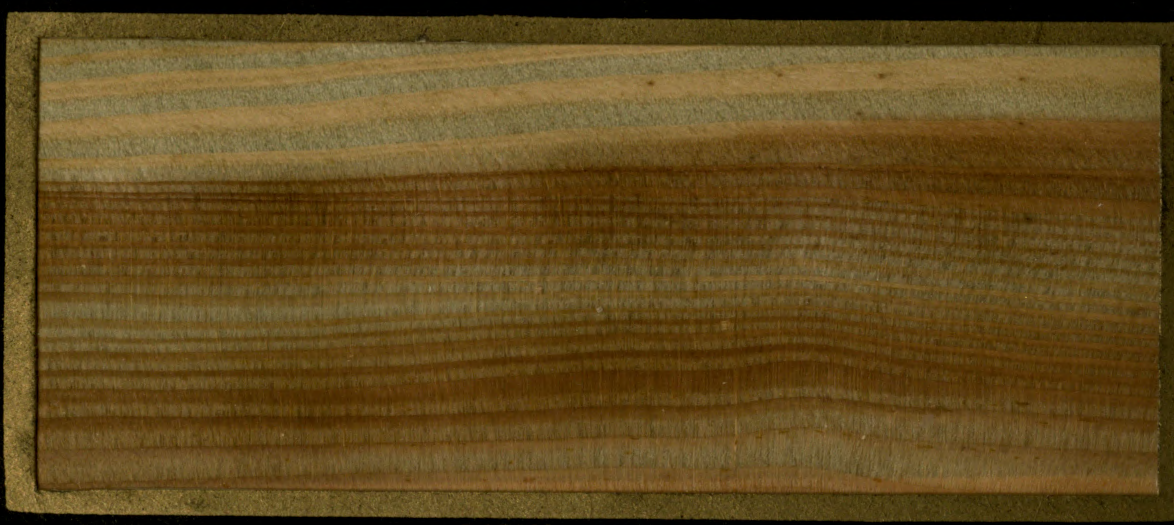

RADIAL SECTION.

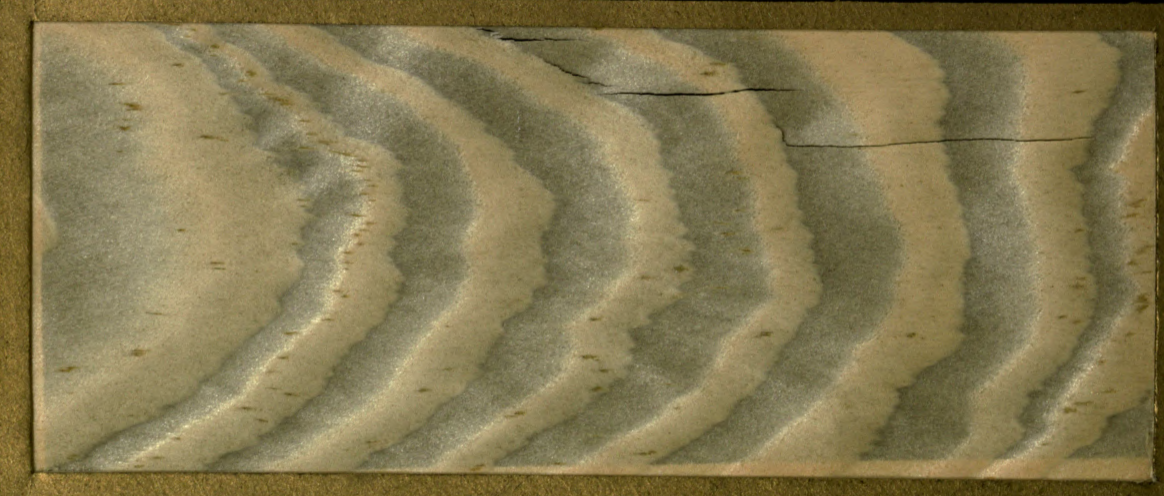

TAMEENTIAL SECTION.

Ser, Amerikanische Larche. Sp, Larice Americana. Titr, Meleze Americain. 
24. THUJA OCCIDENTALIS, L. Arbor-Vitae,

White Codar.

TRAMSVERSE SECTION.

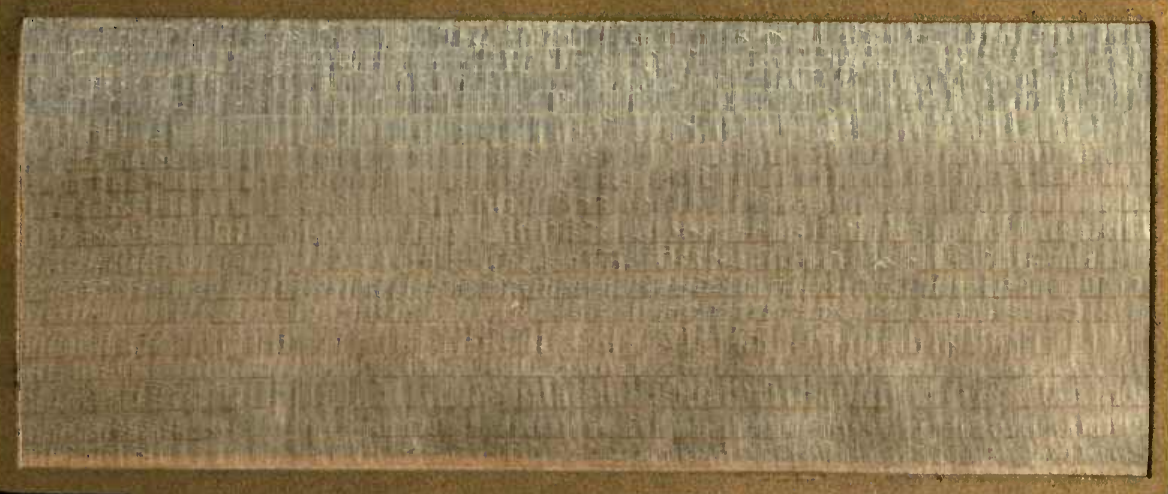

RADIAL OEOTIOM.

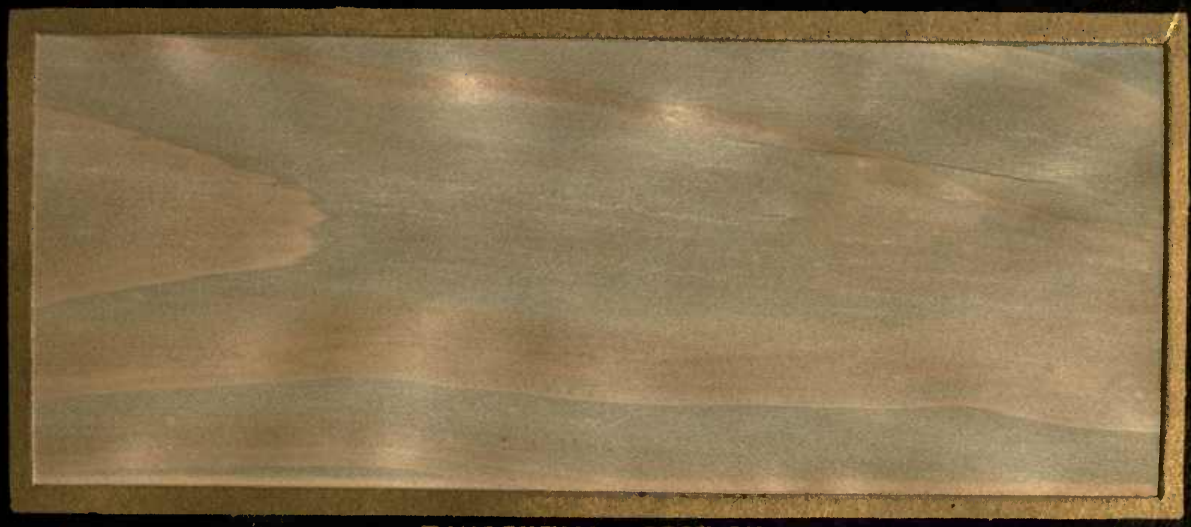

TAMOENTIAL SEOTION.

Ser, Amerikanische Lebendbaum. Sp. Tuya Occidental. Tha Thuja d'Occident. 


\section{THUJA OCCIDENTALIS, L. Arbor-Vitae, \\ White Cedar.}

TRAMSVERSE SECTION.

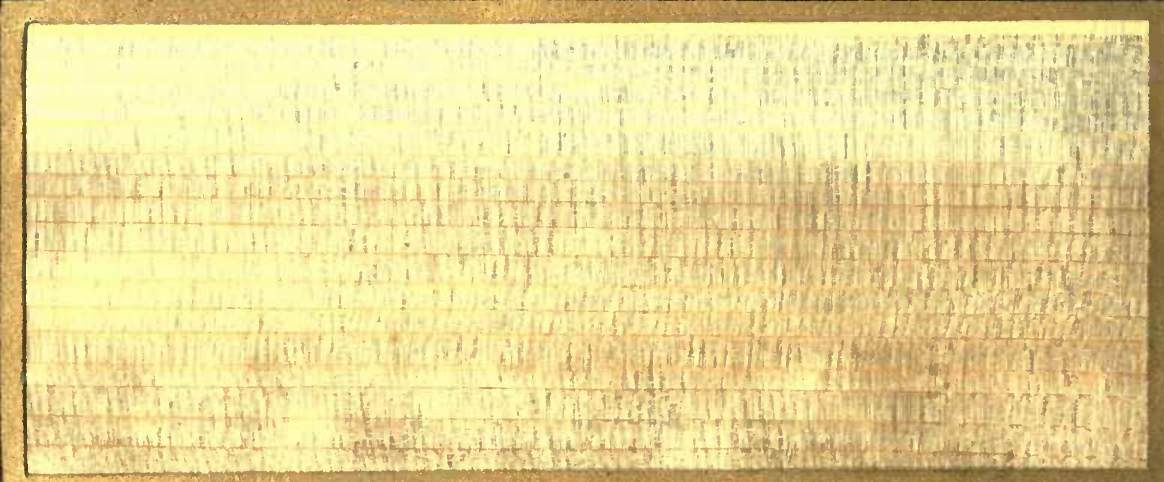

RADIAL SEOTION

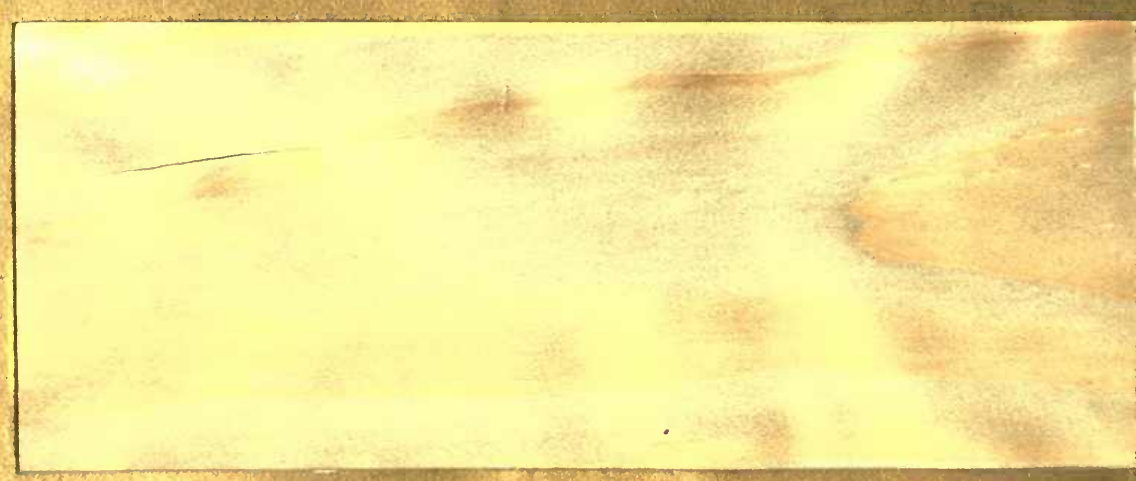

TAMOENTIAL SEOTION.

Ser, Amerikanische Lebendbaum. Sp. Tuya Occidental.

Thr. Thuja d'Occident.

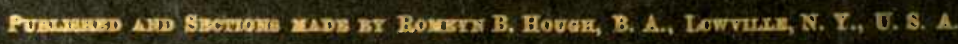




\section{JUNIPERUS VIRGINIANA, L.}

Red Cedar,
Savin,
Pencil Ceder.

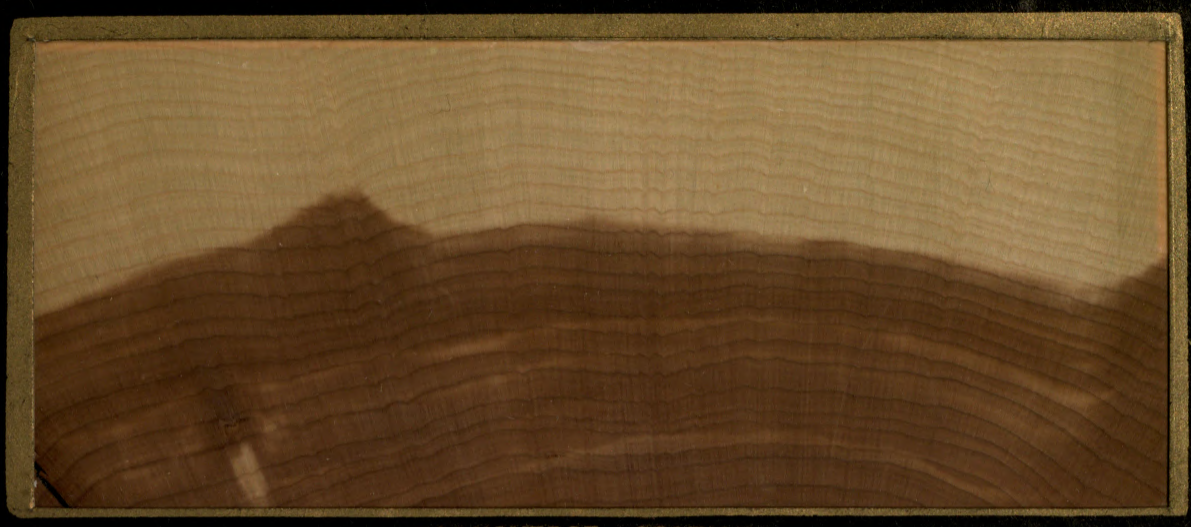

TRANOVERSE BECTION.

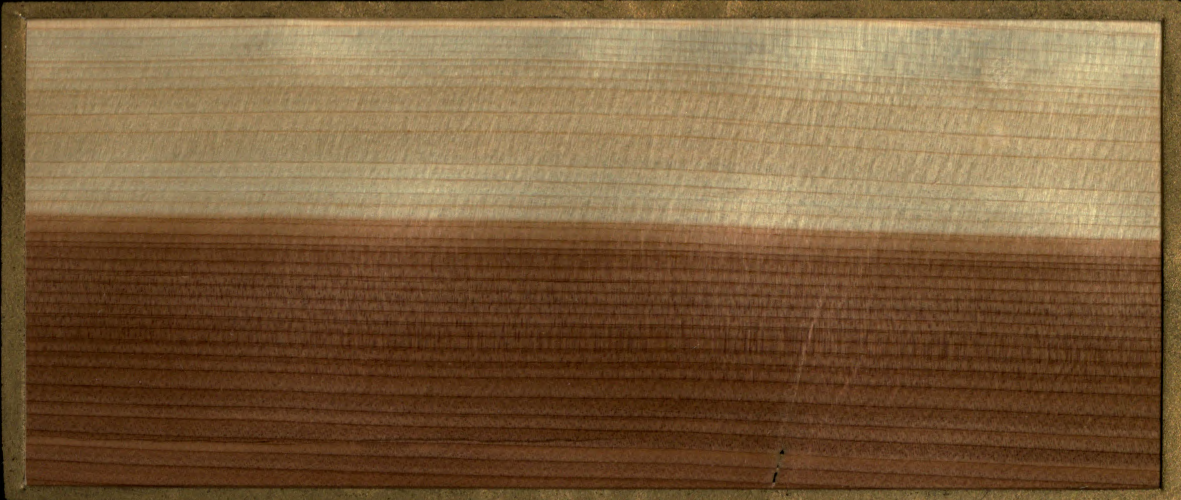

RADIAL SECTION.

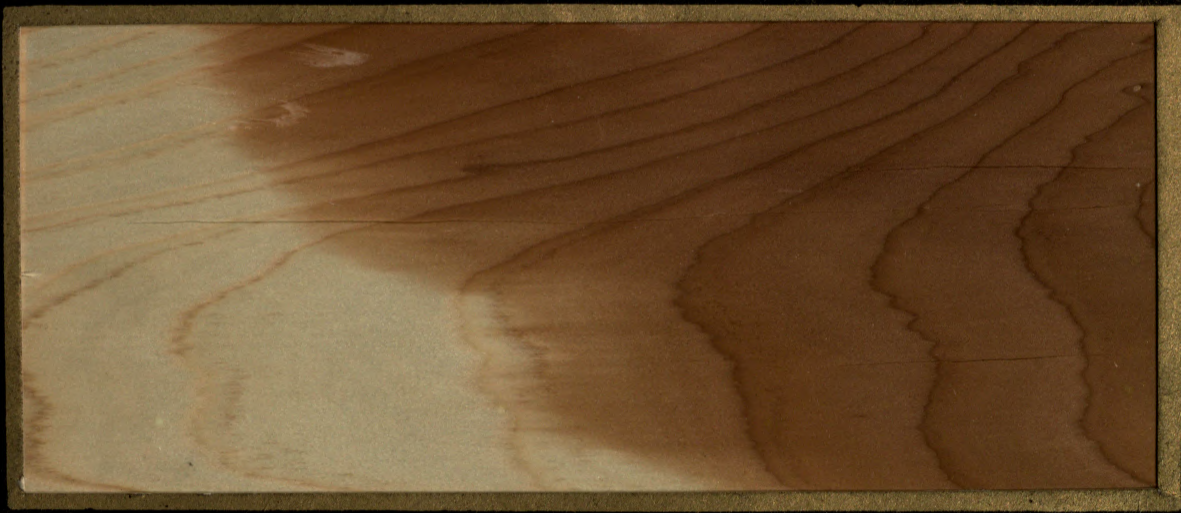

TANGENTIAL SEOTION.

Ser, Virginischer Wachholder. 
25. JUNIPERUS VIRGINIANA, L.
Red Cedar,
Savin,
Pencil Oeder.

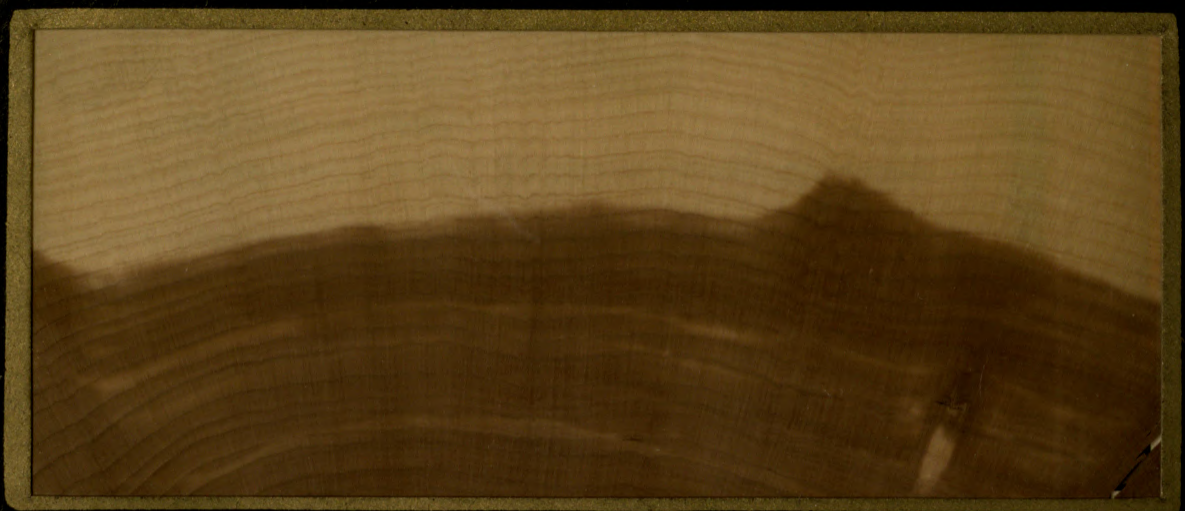

TRANSVERSE SECTION.

RADIAL SECTIOH.

TANOENTIAL BECTION.

Ser, Virginischer Wachholder. 


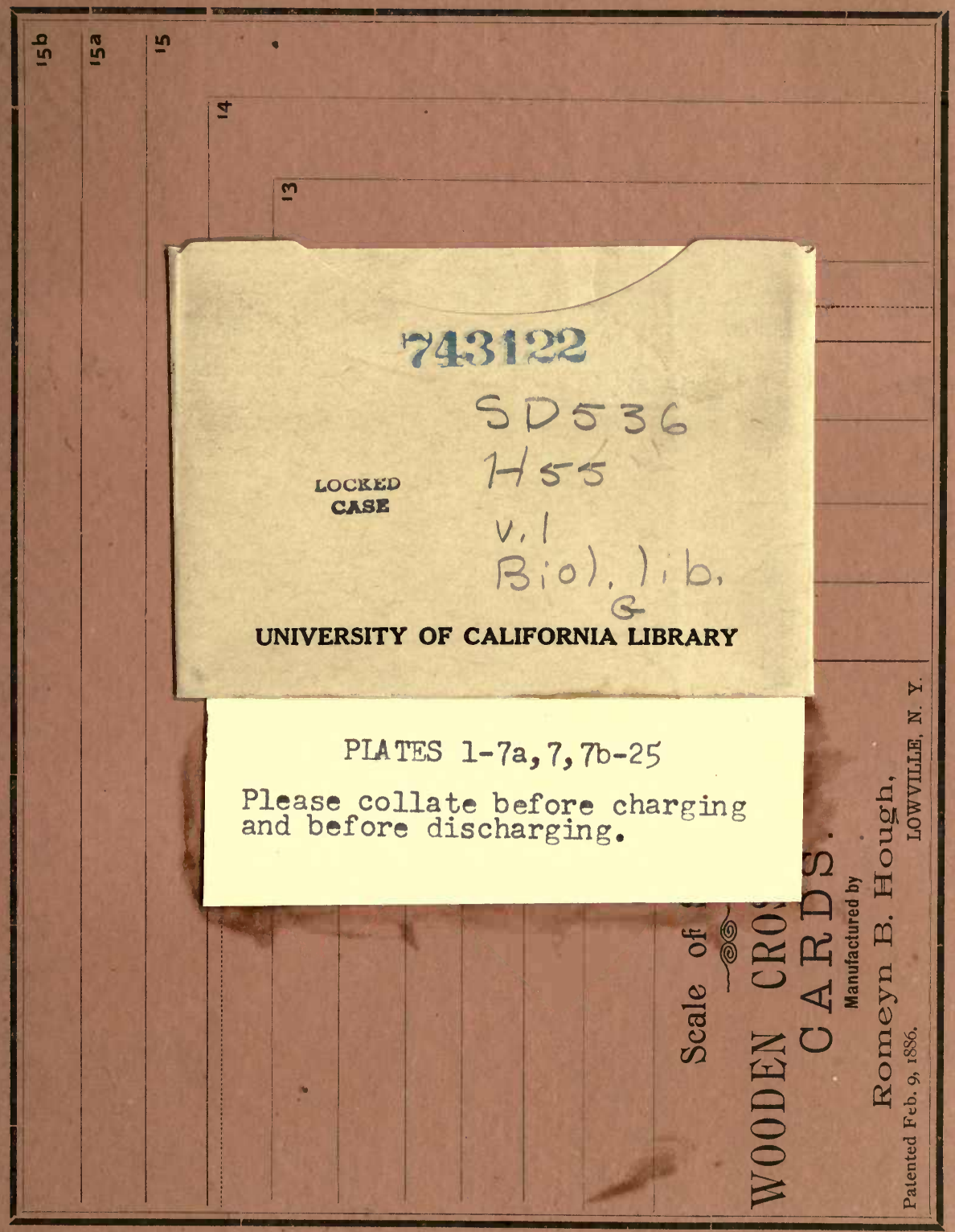


